\title{
Geology of the
}

Pierre Area

South Dakota

GEOLOGIGAL SURVEY PROFESSIONAL PAPER 307

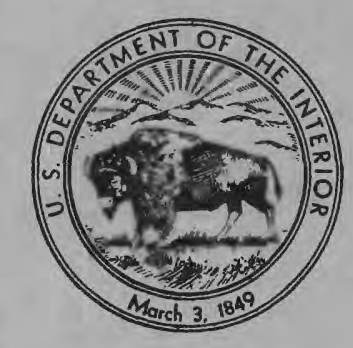




\section{Geology of the}

Pierre Area

\section{South Dakota}

By DWIGHT R. CRANDELL

GEOLOGICAL SURVEY PROFESSIONAL PAPER 307

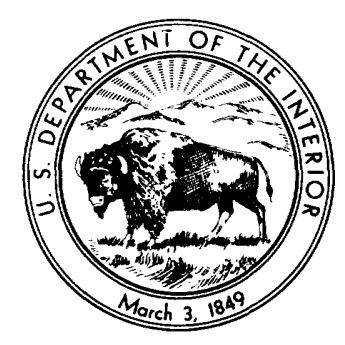

UNITED STATES GOVERNMENT PRINTING OFFICE, WASHINGTON : 1958 


\section{UNITED STATES DEPARTMENT OF THE INTERIOR}

FRED A. SEATON, Secretary

\section{GEOLOGICAL SURVEY}

Thomas B. Nolan, Director

For sale by the Superintendent of Documents, U. S. Government Printing Office

Washington 25, D. C. 


\section{CONTENTS}

Abstract

Introduction

Location, culture, and acce

Purpose and scope of study

Field work and acknowledgments

Earlier studies

Geography

Relief and drair

Climate and vegetation

Soils.

Rock formations

Precambrian rocks

Paleozoic rocks

Cretaceous rocks

Montana group

Pierre shale.

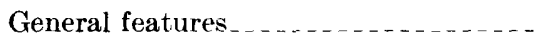

Sharon Springs member............

Gregory member.....................

Crow Creek member................

DeGrey member....................

Verendrye member.................

Virgin Creek member. .............

Mobridge member

Elk Butte member.................

Environment of deposition of the Pierre shale ....................

Fox Hills sandstone.

Absence of deposits of Tertiary age . . . . . . . . . .

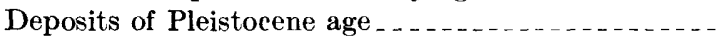

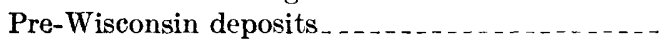

Nonglacial deposits of pre-Kansan age (?)

Nonglacial deposits of probable Yarmouth and Illinoian age.

Absence of deposits of Sangamon age

Deposits of Wisconsin age ...........

Till of the Wisconsin stage

Deposits of the Iowan substage..........

Till _...............

Stratified drift in the Missouri River trench

Proglacial outwash deposits in valleys tributary to the Bad River..........

Alluvial fill in the Bad River trench...

Southwesternmost extent of glacial deposits

Deposits of the Tazewell substage

Till and moraines..................

Stratified drift.

Southwesternmost extent of Tazewell ice

Deposits of the Cary substage........

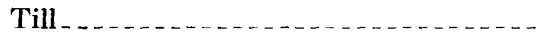

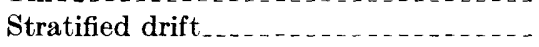

Westernmost extent of Cary ice......

Deposits of the Mankato substage. ......

Deposits of Recent and Pleistocene age.......... Loess.

Description

Fauna.

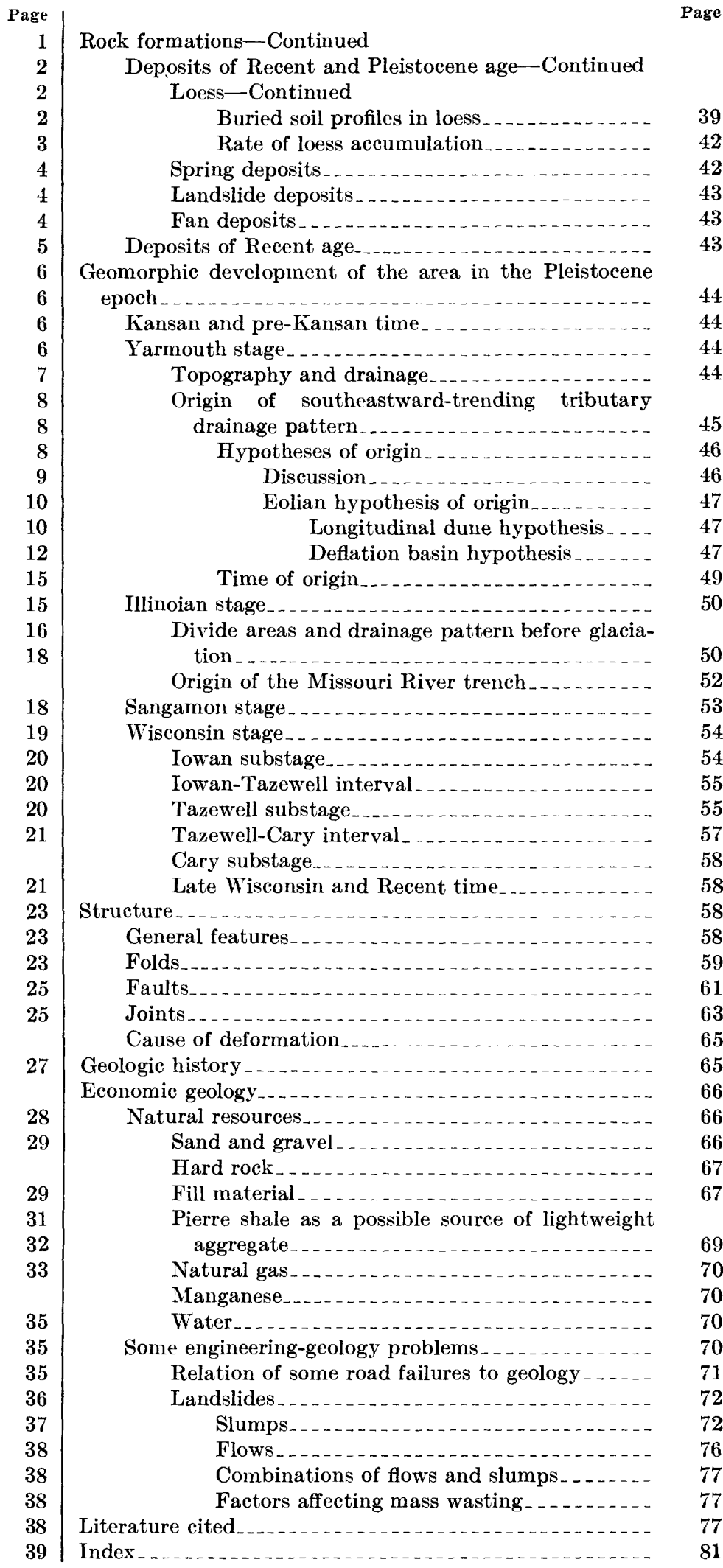

III 


\section{ILLUSTRATIONS}

[Plates are in pocket]

Plate 1. Geologic map of Canning quadrangle, South Dakota.

2. Geologic map of Pierre quadrangle, South Dakota.

3. Geclogic map of Oahe quadrangle, South Dakota.

FIgURe 1. Index map of South Dakota showing location of Pierre area

2. Subsurface formations known from deep borings

3. Relation of true Dakota sandstone to pre-Greenhorn limestone Cretaceous formations of western South Dakota

4. Summary of changes in the stratigraphic nomenclature of the subdivisions of the Pierre shale in central South Dakota since $1937 \ldots \ldots$

5. Crow Creek member as exposed south of the Missouri River in the valley walls of Fort George Creek

6. Cut-and-fill stratification in siltstone of Crow Creek nember.

7. Outcrop of DeGrey and Verendrye members in the valley walls of Antelope Creek in NE1/1NW1/4 sec. 17, T. 4 N., R. 33 E

8. Specimen of the mosasaur Platecarpus ef. brachycephalus Loomis in the shale and bentonite facies of the DeGrey nember near Pierre.

9. Exposure of Verendrye member overlying shale and bentonite facies of DeGrey member near Chantier Creek

10. Geologic map of part of central South Dakota west of the Missouri River

11. Soil profile developed on alluvium of probable Yarmouth age

12. Map showing alluvial deposits of probable Yarmouth and Illinoian age, their range and altitude, in the south half of the Oahe quadrangle

13. Exposure in southeast wall of gully, southeast of Pierre Municipal Airport

14. Wisconsin ice margins in central South Dakota

15. Boulder concentration along north valley wall of Missouri River in the eastern part of the Pierre quadrangle_.

16. Longitudinal profiles of outwash terraces of the Tazewell substage in the Missouri River trench and its tributaries_...

17. Cary till overlying Tazewell outwash southeast of Canning

18. Bison skull from late Wisconsin outwash beneath Missouri River flood plain at Pierre.............

19. Loess deposits overlying Tazewell outwash sand and gravel in the city of Pierre

20. Reconstruction of inferred topography and drainage immediately before formation of the Missouri River trench

21. Deflation basins and tributary drainage pattern in an area southeast of Pierre

22. Diagrammatic cross section of the Missouri River trench in the Pierre area._.

23. Map showing successive positions of the Tazewell ice margin during deglaciation and spatial relation of the margins to inferred pre-Wisconsin topography

24. Structure-contour map of the Pierre area, by M. E. Wing

25. Part of a structure-contour map of a part of the Pierre area, by J. P. Gries

26. Cross section of faults in Pierre shale adjacent to the Bad River.

27. Faults in the Pierre shale exposed in a gully in T. 4 N., R. 29 E

28. Faults in the Virgin Creek member of the Pierre shale in the valley wall of Willow Creek......

29. Polar diagram of joints in Pierre shale at Oahe dam site-

30. Aerial view of slump in DeGrey member of the Pierre shale adjacent to the Bad River in the southeastern part of the Oahe quadrangle.

31. Aerial view of slump in DeGrey and Verendrye members in the south-central part of Oahe quadrangle

32. Aerial view of slump characterized by lateral movement in glacial drift north of Peoria Bottom

33. Slump in glacial drift north of Peoria Bottom

Page

3

7

8

9

11

11

13

14

15

19

23

24

27

30

32

34

36

37

40

45

48

54

56

59

61

62

63

63

64

72

73

74 


\title{
GEOLOGY OF THE PIERRE AREA, SOUTH DAKOTA
}

\author{
By Dwight R. Crandell
}

\begin{abstract}
The Pierre area consists of three 15-minute quadrangles in the approximate center of South Dakota. The area is bisected by the trench of the Missouri River, which forms a boundary between a region mostly covered by glacial deposits that overlie Pierre shale on the northeast and a region of shale on the southwest.

Subsurface rocks known from deep boring include Precambrian granite and quartzite and more than 1,500 feet of marine Paleozoic and Mesozoic rocks. The only bedrock exposed is the Pierre shale of Late Cretaceous age, which is about 1,000 feet thick and consists almost wholly of shale and claystone.
\end{abstract}

Pleistocene deposits include nonglacial stream alluvium derived from the west, ranging in age from Yarmouth to Iowan, and Wisconsin glacial drift. Distribution of the nonglacial alluvium now is restricted to the area southwest of the Missouri River, and even there erosion has left only small remnants of once extensive deposits.

Glacial drift of the Iowan substage sonthwest of the Missouri River consists of scattered glacial boulders and small proglacial outwash deposits in tributary ralleys northwest of the Bad River. In the Missouri River trench, stratified drift of Iowan age records outwash aggradation shortly after the maximum of the substage; northeast of the trench, Iowan deposits have not been recognized owing to the blanket of younger glacial drift. Glacial deposits of Tazewell age are widely distributed northeast of the Missouri River. Proglacial outwash deposits in tributaries of the Missouri River can be traced from Tazewell end moraines northeast of Pierre into the Missouri trench, where they are graded to remnants of a once-continuous outwash valley train. Ground moraine and end moraine of the substage covers nearly all the upland area northeast of the Missouri River.

The distribution of glacial drift of Cary and Mankato age is limited; till of probable Cary age occurs in the northeast corner of the Canning quadrangle, but elsewhere glacial drift of this substage occurs only as proglacial stratified drift in the trenches of the Mrissouri River and Medicine Creek.

Mappable units of both Pleistocene and Recent age comprise spring deposits, landslide deposits, fan alluvium and colluvium, and loess. Spring deposits typically consist of travertine that has cemented sand and gravel to form conglomerate; these deposits occur in outcrops of small areal extent along the walls of the Missouri River trench and the valley of Medicine Creek. Landslide deposits include Pierre shale and glacial drift that have been involved in slumping, flowage, or a combination of the two processes. Fan deposits typically consist of alluvium and colluvium in coalescent alluvial fans between the base of Pierre shale outcrops in valley walls and the Recent alluvium of the valley floors. Probably the most widespread geologic unit in the area is loess of Wisconsin and Recent age, although southwest of the Missouri River it is thin and not continuous laterally. A buried soil profile that is inferred to represent the Tazewell-Cary interval has been recognized locally in the loess. As much as $51 / 2$ feet of loess has accumulated in the last 460 years in favorable locations.

Deposits of Recent age include flood-plain and terrace alIuvium along the axes of the principal stream valleys of the area. This alluvium reaches a maximum thickness of about 75 feet beneath the Missouri River flood plain, but it probably includes outwash deposits of Mankato and Cary age lying between the bedrock floor of the trench and the base of the Recent alluvium.

Structural dislocations recognized in the area include folds and faults of seemingly random orientation in the Pierre shale. Folds typically are small in anplitude and apparently limited in length along the strike to several hundreds of yards. Faults are chiefly of the normal type, and displacements range from a few inches to several tens of feet.

Prior to the Illinoian stage the Pierre area was crossed by the ancestral Bad River, an eastward-flowing master stream that antedated the Missouri River trench. In the Illinoian stage a glacier dammed this and the other eastward-flowing master streams of central South Dakota so that drainage from the west and melt water from the glacier fed ever-deepening lakes in the valleys of these master streams. Eventually each of these lakes overflowed and spilled over low divides into adjacent drainage basins. Through integration of channels formed in this way the Missouri River trench came into being. The trench was widened and, possibly, deepened nearly to its present dimeusions during the Sangamon interglacial stage.

Since mid-Pleistocene and possibly early Pleistocene time eolian erosional and depositional features have been factors influencing the formation of a tributary drainage system in northwesterly and southeasterly directions. The result is a remarkable southeast lineation of ridges and valleys in the Pierre shale southwest of the Missouri River.

The glacier of the Iowan substage crossed the Missouri River trench and extended westward over most of the Pierre area. Melt water built valley trains of sand and gravel in the trenches of the Missouri River and some of its tributaries. Most of these deposits were removed after the retreat of the glacier from the area and before the Tazewell substage. The Tazewell glacier locally reached the Missouri trench in the Pierre area but did not extend across to the opposite upland. While the ice margin was standing in or very close to the trench, a valley train of outwash sand and gravel accumulated in the trench to which tributary melt-water streams were graded during the subsequent retreat of the glacier. In the course of retreat, two massive end moraines were built in the Pierre and Canning quadrangles. Soon after the retreat of the Tazewell glacier from the area the outwash train in the 
Missouri River trench was dissected, and during the TazewellCary interval the present bedrock floor of the trench was cut to a depth of about 60 feet beneath the present flood plain.

The Cary substage was marked by the advance of another glacier into the northeast corner of the area. During this substage the Missouri River again aggraded in response to the load of outwash sand and gravel contributed by melt water.

Since Cary time there has been little change in the physiography of the area. The surface now is being slowly lowered by stream erosion, deflation, and mass-wasting processes. These processes are more active southwest of the Missouri River, where the surface is underlain chiefly by the relatively impermeable Pierre shale, than in the region to the northeast where a poorly integrated drainage system and permeable glacial drift oppose vigorous erosion.

Construction materials of the area include small amounts of hard rock (glacial erratics), and sand and gravel deposits. The supply of glacially derived sand and gravel is very large, but these materials are not recommended for use in high-grade concrete. Preliminary tests on Pierre shale indicate that some of it is suitable for the preparation of lightweight aggregate.

Although natural gas has been produced at Pierre for more than 60 years, production has nerer been adequate for more than local consumption.

A very important resource of the area is its supply of potable water. At present, an adequate supply for the towns of Pierre and Fort Pierre is obtained from the alluvium and glacial sand and gravel beneath the Missouri flood plain. On upland areas northeast of the Missouri River, domestic water supplies are most commonly obtained from shallow wells that tap permeable beds in glacial drift, although some water is obtained from deep artesian wells that tap the Dakota sandstone of Early Cretaceous age. On upland areas southwest of the Missouri River, water is obtained from artesian wells and from reservoirs in which surface runoff is impounded.

The high susceptibility of the Pierre shale to landsliding poses important engineering problems in the area; recognition of dormant or potential slide areas is essential to sound construction practice and design. The chief contributing factors to landslides are increased pressure of interstitial water during and shortly after periods of heavy precipitation and natural or artificial excavation at the toes of dormant landslides or potentially unstable slopes.

\section{INTRODUCTION}

\section{LOCATION, CULTURE, AND ACCESSIBILITY}

The Pierre area includes the Oahe, Pierre, and Canning 15-minute quadrangles in South Dakota; these quadrangles span the Missouri River in the approximate geographic center of the State (see fig. 1, and geologic map, pls. 1, 2,3).

The Missouri River forms the boundary between Hughes County on the northeast and Stanley County on the southwest. For Pierre, on the west bank of the Missouri River, is the county seat of the latter, and the city of Pierre (population 5,715 in 1950), on the east bank directly opposite Fort Pierre, is the Hughes County seat and State capital. These two towns are the largest and virtually the only communities in the three quadrangles. The village of Canning, on Medicine Creek in the eastern part of the Canning quadrangle, is the only other community, although at Rousseau, 5 miles south of Canning, there exists a school, gas station, and garage. Both the Rousseau postoffice and the Oahe postoffice, formerly located in the western part of Peoria Bottom, have been discontinued. Wendte, a small community on a branch of the Chicago and North Western Railway, is situated on the Bad River flood plain 0.5 miles south of the south edge of the Oahe quadrangle. The town of Blunt is located adjacent to the same railroad on the valley floor of Medicine Creek, one mile northeast of the northeast corner of the Canning quadrangle.

The principal transportation routes of the area are the Chicago and North Western Railway and U. S. Highways 14 and 83. In addition, State Route 34, originating at Pierre and following the Missouri River eastward through the Pierre and Canning quadrangles, continues eastward and southeastward to the southeastern part of the State. There are many section-line roads, a few graveled, in addition to these all-weather roads in the area northeast of the Missouri River. Southwest of the Missouri, all-weather roads are practically nonexistent except for U. S. Highways 14 and 83 and a graveled road along the valley of the Bad River.

\section{PURPOSE AND SCOPE OF STUDY}

The geologic investigation of the Pierre area was undertaken as a project in a broad plan of the Federal Government for developing the resources of the Missouri River basin. One unit of this broad plan is the construction, by the Corps of Engineers, U. S. Army, of the multipurpose Oahe Dam (pl. 2) which ultimately will span the Missouri River about 51/2 miles upstream from the city of Pierre. A large reservoir will thus be created that will extend northward into North Dakota. Part of the water from this reservoir will be diverted eastward through the Pierre and Canning quadrangles by a system of canals into the Oahe irrigation unit, about 100 miles east of Pierre; this part of the program is under the supervision of the Bureau of Reclamation.

Inasmuch as details of the surface and subsurface geology at the Oahe Dam site and along the alinment of the canal system have been and will continue to be comprehensively investigated by the geologists of the Federal agencies concerned, the primary objective of this project has been to study some of the broader geologic problems of the area. Such a study in the Pierre area has proceded concurrently with two other areal studies by the U. S. Geological Survey in the 


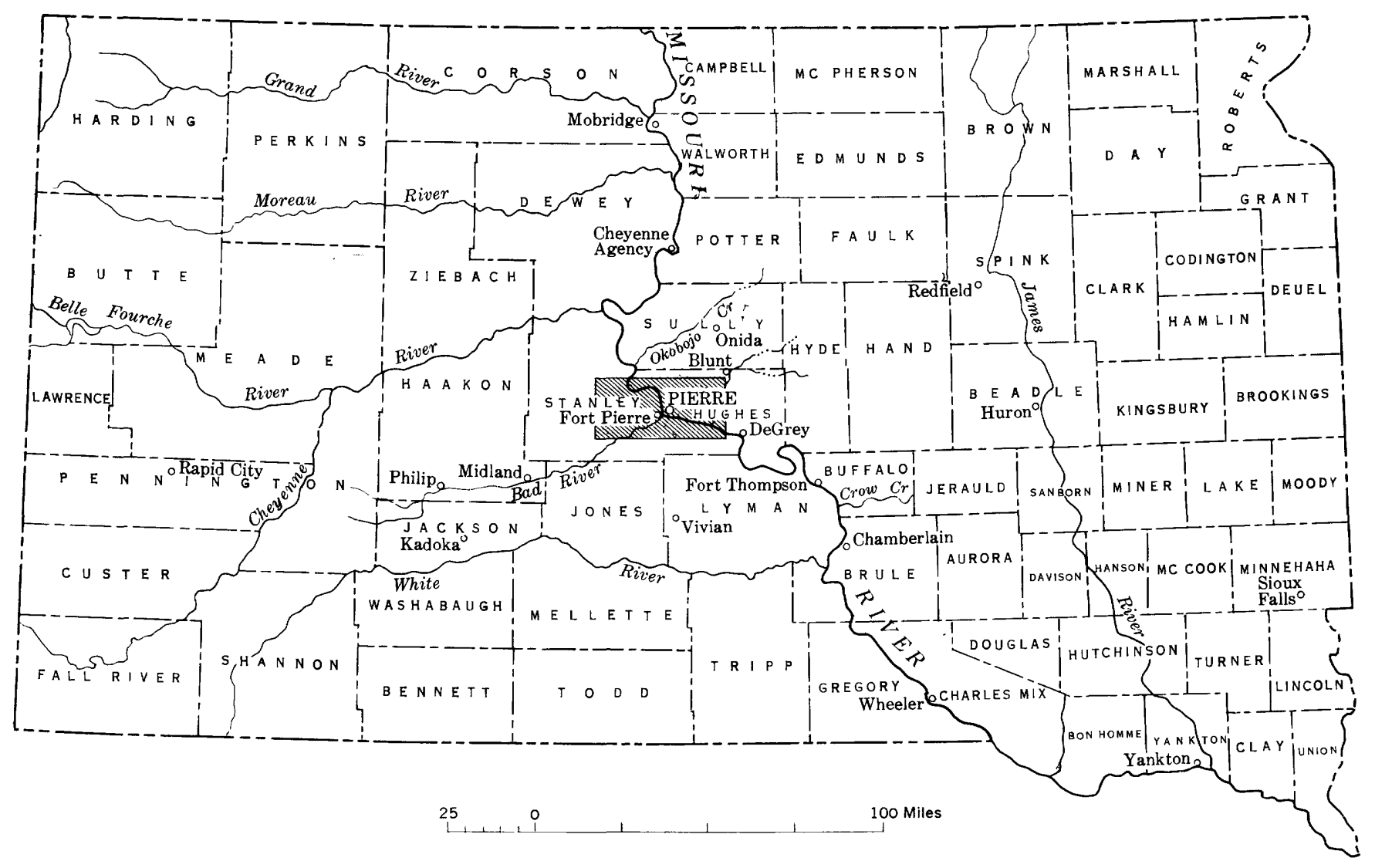

Figure 1.-Index map of South Dakota showing location of the Pierre area.

vicinity of Chamberlain and Yankton, S. Dak., and with an investigation of even broader scope, which has dealt with the Pleistocene geology of the glaciated portion of the State.

The purpose of this report is to present, as fully as now possible, the geology of the Pierre area. Reports on the individual quadrangles have already been published and short papers have been published in various scientific journals on problems of special geologic interest.

\section{FIELD WORK AND ACKNOWLEDGMENTS}

The field work on which this report is based was done in the months of June, July, and August of the years 1948 to 1950, and in June and August, 1952. The author was assisted in 1948 by J. R. Hensley, in 1950 by D. W. Hammerquist, and in June 1952 by C. F. Erskine.

Geologic mapping was done chiefly on aerial photographs, scale 1: 20,000 , prepared in 1939 for the Agricultural Adjustment Administration of the U. S. Department of Agriculture. The altitudes of contacts were determined with a Paulin altimeter, and the formational contact lines were transferred by the author from the photographs to base maps of each quadrangle.

The author was aided greatly in this investigation by the wholehearted cooperation of the people of Pierre and Fort Pierre and the surrounding area. Foremost among them were Mr. and Mrs. W. H. George of Pierre, who are deeply interested in the natural history of the region and who aided in countless ways during the field investigation.

Personnel of the Oahe area office and Omaha district office, Corps of Engineers, U. S. Army provided information regarding the subsurface geology in the vicinity of the Oahe Dam; appreciation is likewise expressed for many other courtesies extended by the personnel of the Oahe area office which greatly facilitated field work. The author also acknowledges the cooperation and benefit of stimulating discussions with the following personnel of the Soils Testing Laboratory of the State Highway Commission: A. W. Potter, engineer in charge; E. E. Meleen, assistant soils engineer, and E. B. McDonald, soils engineer. H. C. Rempfer, State highway engineer, kindly made the facilities of the Soils Testing Laboratory available for the testing of samples of the various map units in the area. 
The Cretaceous invertebrate fossils were identified by K. M. Waagé, Peabody Museum, Yale University, and the Cretaceous vertebrates by D. H. Dunkle, U. S. National Museum. The Pleistocene vertebrate fossils were identified by C. W. Hibbard, Museum of Paleontology, University of Michigan and by C. B. Schultz, director, Nebraska State Museum. A. B. Leonäd, Department of Zoology, University of Kansas, identified the Pleistocene gastropods.

Appreciation is expressed to R. F. Flint, Department of Geology, Yale University for making many contributions to the solution of the problems of the area during field conferences and office discussions, and in criticisms of the several preliminary reports.

\section{EARIIER STUDIES}

The geology of the Pierre area was examined by many geologists during the latter half of the 19th century; most of them were concerned principally with the stratigraphy of the Cretaceous rocks of the northern Great Plains. This interest was implied by Hayden $(1869$, p. 40) in the following observation concerning the geology of the Pierre area :

Now and then a fragment of a baculite, ammonite, or inoceramus is seen, and along the Teton [Bad] river a few bones of the mosasaurus have been discovered, but there is very little in this region to attract the attention of a geologist.

One outgrowth of these early studies was the assignment of the name Fort Pierre group by Meek and Hayden to what previously had been called Formation No. 4 of the Cretaceous (Hall and Meek, 1856, p. 405); the type section of the Fort Pierre group was designated by a statement by Meek and Hayden (1861, p. 424) that "This formation composes all the hills on both sides of the Missouri at Fort Pierre, . .."

In the latter part of the 19th century and in the early part of the 20th century the geology of central South Dakota was incidentally mentioned in several reports covering broader regions (for example, Todd, 1894; Darton, 1905), but it was not until the late 1920's and 1930's that intensive work was started in areas along the Missouri River trench in the central part of the State. For the most part, this work emphasized stratigraphy and structure of the Pierre shale.

The first comprehensive investigation of the stratigraphy of the Pierre shale was made by Searight (1937), who included several measured sections near Pierre. The following year, Wing (1938) constructed a structure-contour map of the Pierre shale along the Missouri River trench from Peoria Bottom to Antelope Creek and several miles up the valley of the Bad River. Gries (1940) later studied the stratigraphy and struc- ture of the Pierre shale in northeastern Stanley County. Several subsequent reports of the State Geological Survey have included the investigation of specific geologic features in and adjacent to the Pierre area (Rothrock and Robinson, 1936; Gries, 1942; Rothrock, 1944; 1946 ; Petsch, 1946; and Baker, 1947). The moraines of the Pierre area were described by Todd (1894, 1896, 1902, and 1923).

Concurrently with the field investigations in the Pierre area, five adjacent 15-minute quadrangles were mapped independently by the State Geological Survey (Petsch and Bolin, 1950; Petsch and Curtiss, 1950; Bolin, 1951; Curtiss, 1951; and Petsch, 1952).

\section{GEOGRAPHY}

The Pierre area is near the eastern edge of the Missouri Plateau section of the Great Plains. The area is separated by the Missouri River trench into the Coteau du Missouri on the east and the Pierre hills on the west. These two physiographic regions are geologically very different in the Pierre area: the Pierre hills region consists almost wholly of members of the Pierre shale of Late Cretaceous age, whereas the Coteau du Missouri is characterized by glacial drift, locally as much as 220 feet thick. This drift, in turn, rests on Pierre shale.

\section{RELIEF AND DRAINAGE}

The most notable topographic feature of the Pierre area is the trench of the Missouri River, which is from 2 to 4 miles wide and, in most places, 300 to 400 feet deep. When approaching the trench from the east, one scarcely is aware of its presence until within a mile or 2 , in places a few hundred yards, of the trench rim. The Missouri River flood plain is not a continuous feature, but consists of narrow strips of land on the side of the valley opposite that which is now occupied by the river.

The walls of the trench locally are interrupted by conspicuous terraces ranging in width from a few hundred feet to as much as 2 miles and of comparable length. These and other terraces along the Missouri River were observed by F. V. Hayden who remarked $(1863$, p. 114) that ". . . we can hardly doubt that the terraces result from the gradual elevation of the Rocky mountain range." More recent studies by geologists of the State and Federal geological surveys indicate that the terraces without exception are underlain by gravels of glacial derivation, and thus owe their origin to aggradation by glacial melt water, and their height above the present flood plain to subsequent dissection. 
The principal tributary of the Missouri in the Pierre area is the Bad River which heads in eastern Pemmington County, flows northeasterly, and enters the Missouri River at Fort Pierre. The flood plain of the Bad River lies about 300 feet below the uplands immediately adjacent and the trench itself is about 1 mile wide. Although the Bad River trench has a general northeasterly trend in the Oahe and Pierre quadrangles, there are many bends in its course, and the Bad River itself meanders across its flood plain from one valley wall to the other.

Smaller tributaries of the Missouri River are Medicine Creek in the eastern part of the Camning quadrangle, Antelope Creek in the southwestern part of the same quadrangle, and Dry Run, which drains the western part of the Canning quadrangle and joins the Missouri 3 miles east of Pierre.

There are no natural lakes in the area. In the past 25 years, several artificial lakes have been formed by damming parts of stream valleys. One of these, Lake Arikara, is located in the valley of Dry Run near the junction of the Canning and Pierre quadrangles. A larger lake was made by the construction of a causeway from the north bank of the Missouri River to the upstream end of Farm Island; this lake is more properly termed a backwater of the Missouri River. Lake Chesley at Canning was formed by damming a meander of Medicine Creek.

After a wet spring, many temporary lakes and marshes exist in shallow depressions, both in morainal areas northeast of the Missouri River and in deflation basins in Pierre shale southwest of the river. Many of them dry up during summer months.

Many dams have been constructed in small valleys since 1930 to catch and store rumoff. Such ponds generally are only a few acres in areal extent.

The reservoir impounded in the Missouri River trench behind the Oahe Dam will greatly exceed in size any existing body of water in the area. This lake will cover an area of about 25 square miles in the Pierre and Oahe quadrangles when the dam is completed.

For convenience, description of land forms in the Pierre area will be subdivided into the areas southwest and northeast of the Missouri River.

Northeast of the Missouri River trench, the upland surface is gently rolling groumd and end moraine at altitudes ranging from 1,700 to 1,800 feet. The local relief is about 50 feet. Three prominent ridges, or rounded buttes, stand above this upland surface. Snake Butte, 3 miles morth of Pierre, has an altitude of 1,922 feet and stands 100 to 200 feet above the surrounding upland. Medicine Knoll, in the northeast corner of the Camning quadrangle, stands 200 feet above the adjacent upland and has an altitude of about 2,030 feet. This ridge is such a prominent topographic feature that it can be seen for many miles in all directions. A third less prominent ridge is a low hill in the southeast comer SW1/4 sec. 7, T. 111 N., R. 75 W., 5 miles southwest of Medicine Knoll. Body Ranch, unoccupied at the date of this report, is near the crest of this hill, and, because the name Body Ranch appears on the topographic map of the Canning quadrangle, the name "Body Ranch hill" will be used in an informal sense to designate this topographic feature. Body Ranch hill has an altitude of a little more than 1,900 feet, but although it stands 100 feet above the adjacent upland surface, it is not a commanding feature of the landscape.

Southwest of the Missouri River the most conspicuous physiographic feature is a southeastward-trending pattern of drainage tributary to both the Bad River and the Missouri River. Erosion of the upland areas has progressed to the stage at which, in much of the Pierre and Oahe quadrangles, interfluves are little more than narrow southeastward-trending ridges. The result is a remarkable topographic grain. The three largest streams that cut across this grain in the Pierre area are the Bad River, Antelope Creek, and Willow Creek.

The surface southwest of the Missouri River locally has not yet been reached by deep dissection and is gently rolling; Giddings Flat and an area in the southeastern part of the Pierre quadrangle are the most extensive representatives of this surface. Several ridges and buttes stand above the general altitude of these broad, rolling surfaces and above the narrow interfluves between tributaries of the Bad River. One, Willow Creek Butte near the center of the Oahe quadrangle, was long used as a landmark by wagon trains traveling between Fort Pierre and Deadwood in the Black Hills.

\section{CIIMATE AND VEGETATION}

Over a period of 39 years (U. S. Department of Agriculture Climatology Records for Pierre, 18911930 ), the mean annual precipitation at Pierre was 16.68 inches, of which 58 percent fell during May, June, July, and August. For the same period, the monthly normal temperature ranged from a low of $16^{\circ} \mathrm{F}$. in January to a high of $75.3^{\circ} \mathrm{F}$. in July. The maximum recorded temperature was $115^{\circ} \mathbf{F}$. and the minimum recorded temperature was $-40^{\circ}$ F. (July and February, respectively, years not known.) An average growing season for the area is 140 days. During the months of October to April, inclusive, the prevailing winds are from the northwest; prevailing winds are from the 
east during May, and from the southeast during the remaining months.

The principal types of vegetation on the uplands are sagebrush and grasses and in the valleys, willows, cottonwoods, and a few cedar trees. Trees on upland areas are rare.

\section{soIrs}

The soils of the Pierre area typically are of the Chestnut soils group, characterized by a dark brown to brownish black $A$ horizon, underlain by a lighter colored $B$ horizon that has a finer texture than the $A$ horizon owing to the presence of clay and colloids derived from that horizon. The $B$ horizon and the underlying parent material may be enriched in secondary calcium carbonate. The Chestnut soils of the Pierre area merge eastward with the Chernozem soils which are darker owing to slightly greater humidity and thereby more organic matter in the soil. Westward the Chestnut soils merge with Brown soils, characterized by a lighter colored $A$ horizon owing to greater aridity and thereby less included organic matter.

Soils developed on Pierre shale consist of an $A$ horizon of dark-grey to olive-gray clay, and a $B$ horizon of olive-gray to olive-brown clay. Secondary calcium carbonate may be present in the $B$ horizon and in the underlying weathered shale. The depth of this soil and the thickness of the individual horizons depends in large measure on the amount of surface slope in a given area; on steep slopes the individual horizons of the soil profile commonly are lacking and weathered shale crops out at the surface. In areas where slopes are gentle and the soil profile has been forming for a long time, weathered shale may be buried under as much as 8 feet of clay.

The thickness and character of soil profiles formed on Pleistocene deposits are greatly influenced by the age and character of the parent material. For example, on glacial drift of Wisconsin age northeast of the Missouri River generally a soil has formed that ranges from a few inches to about 2 feet thick. This soil typically is highly alkaline with a $\mathrm{pH}$ of 7 or 8 ; leaching of calcium carbonate generally extends less than 6 inches from the surface. In areas mantled with Recent loess, the surface soil locally consists only of a slight darkening of the uppermost few inches of the loess with orgamic matter, and the loess is calcareous to the surface. This type of soil is present also in dissected areas where the formation of the soil profile has been retarded by erosion.

West of the Missouri River, very old soil profiles have been observed on Pleistocene deposits of preWisconsin age. In them, leaching of calcium carbonate commonly extends to a depth of 15 inches, the $A$ horizon is slightly to strongly acidic ( $\mathrm{pH}$ ranging from 6 to 4 ), and there is much secondary calcium carbonate.

\section{ROCK FORMATIONS}

The rock formations of the Pierre area are readily divisible into bedrock of Pierre shale and Quaternary surficial deposits. The Pierre shale represents the deposits of an inland sea that once spread over most of the area of the northern Great Plains and much of the Rocky Mountains. The Quaternary formations are mostly unconsolidated sediments formed on land as glacial, stream, mass-wasting, and wind deposits.

In one sense, the distinction between bedrock and surficial deposits in the area is not a significant one because there is no considerable difference in degree of consolidation between Pierre shale and, for example, till. Nonetheless, the Pierre shale must be considered the bedrock of the region; hard rock in the sense of granite or quartzite lies more than 1,500 feet beneath the surface.

Rocks older than Upper Cretaceous in central South Dakota are known only from deep drill holes. Four borings (fig. 2) in Stanley County have reached the Precambrian basement; a fifth, in Hughes County, reached Lower Ordovician(?) rocks, probably only a short distance above the Precambrian basement. Logs of these borings were assembled by Baker (1957), on whose report most of the following information is based.

\section{PRECAMBRIAN ROCKS}

The Precambrian basement rock in borings 3 and 4 (fig.2), at depths of 500 and 800 feet below sea level, is quartzite which has been correlated with the Sioux quartzite, of probable Huronian age, of southeastern South Dakota. In boring 2,6 miles west of the northwest corner of the Oahe quadrangle and 13 miles northwest of boring 4 , Paleozoic rocks lie directly on granite at a depth of 2,000 feet below sea level. The thickness of the Sioux quartzite is not known in the Pierre area; the quartzite very likely postdates the crystalline rocks in borings 1 and 2 .

\section{PALEOZOIC ROCKS}

Several Paleozoic formations logged in drill holes 1 and 2 (fig. 2) thin toward the southeast and others either wedge out or have not been identified in that direction. The section of Paleozoic rocks decreases in thickness from 1,680 feet in northern Stanley County to less than 300 feet at Pierre, a distance of about 27 miles. This thinning continues toward the east; near Huron in Beadle County (fig. 1), Rothrock (1946) 


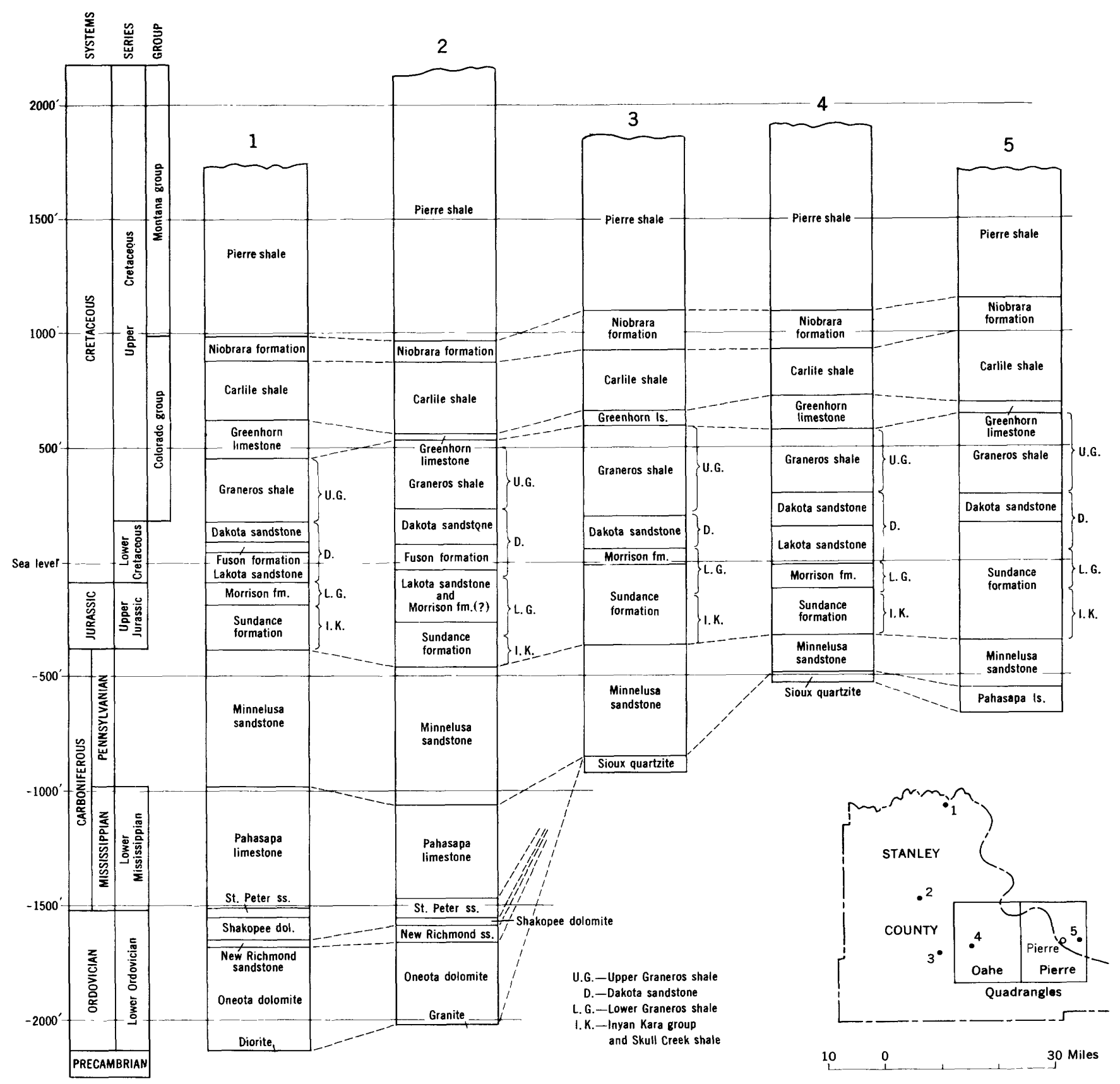

FIGURE 2.-Subsurface formations known from deep borings. Data and suggested correlations from Baker (1947). An alternative correlation for some of the Cretaceous formations based on a suggestion by Gries (1954) is given at the right of each section.

reported that Dakota sandstone of Cretaceous age rests directly on Sioux quartzite at an altitude of 162 feet.

\section{CRETACEOUS ROCKS}

The local representatives of the Lower Cretaceous series are the correlatives of the Inyan Kara group, Skull Creek shale, and Dakota sandstone . For several years the correct correlation of rocks younger than the Minnelusa sandstone and older than the Greenhorn limestone in deep boreholes in central South Dakota has been in some question. Baker (1947) correlated these rocks with the Sundance and Morrison formations of Late Jurassic age, the Lakota sandstone, Fuson formation, and Dakota sandstone all of Early Cretaceous age, and the Graneros shale of Late Cretaceous age (see fig. 2). Gries (1953, 1954) suggested, however, that the Jurassic formations logged in deep boreholes in the central part of the State probably are beds 
equivalent in age to the Dakota sandstone of southeastern South Dakota, and to the Inyan Kara group, Skull Creek shale, Newcastle sandstone, Mowry shale, and Belle Fourche shale of the Black Hills region (fig. 3).

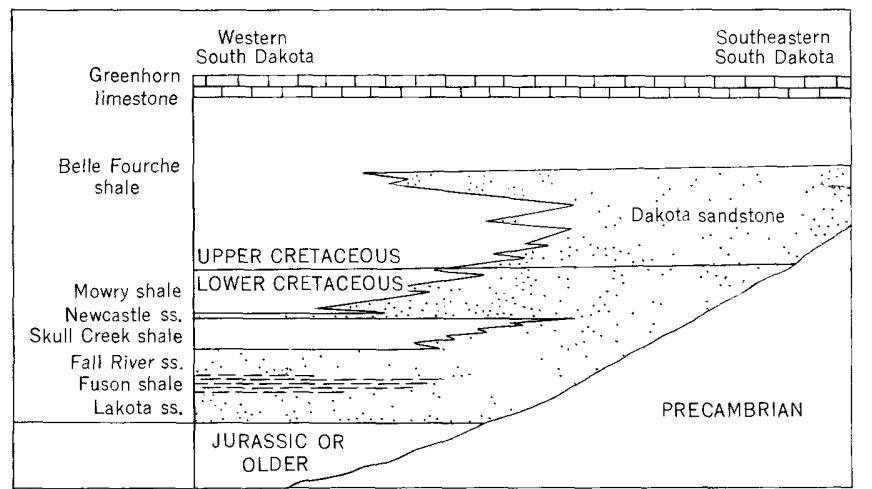

Figure 3.-Relation of true Dakota sandstone to Cretaceous formations older than Greenhorn limestone of western South Dakota. Redrawn from Gries (1954, fig. 4) ; suggested boundary between Lower Cretaceous and Upper Cretaceous added by author.

The Upper Cretaceous rocks that underlie the Pierre area are correlated, from older to younger, with the Dakota sandstone, Graneros shale, Greenhorn limestone, Carlile shale, Niobrara formation, and Pierre shale. The formations older than the Pierre shale crop out in the southeastern part of the State, and the Niobrara formation is exposed in the Missouri River trench as far north as Fort Thompson (fig. 1).

\section{MONTANA GROUP}

\section{PIERRE SHALE}

GENERAL FEATURES

The only bedrock that crops out in the Pierre area is the Pierre shale, a formation that gives "the country underlaid by it a most gloomy and sterile aspect" (Hayden, 1863, p. 76). The formation originally was named Fort Pierre group (Meek and Hayden, 1861, p. 419) from exposures near the fur-trading post of Fort Pierre, which at that time was situated on the Missouri River flood plain about 4 miles north of the present community of the same name. By general usage the formational name has been shortened to Pierre shale.

Since 1930, the stratigraphy and structure of the Pierre shale along the Missouri River trench in South Dakota has been studied by the State Geological Survey (Russell, 1930; Searight, 1937; Wing, 1938; Gries, 1939, 1942; Wing and Gries, 1941; Rothrock, 1943, 1947; and Petsch, 1946). In some of these reports, terminology of the lithology of the formation has not been consistent, thus the present usage of several applicable terms is given herewith so that misinterpretation will be avoided in the subsequent discussion.
Clay is used in essentially the sense indicated by Grim (1942, p. 226) :

(1) a natural material with plastic properties, (2) an essential composition of particles of very fine size grades and (3) an essential composition of crystalline fragments of minerals that are essentially hydrous aluminum silicates or occasionally hydrous magnesium silicates.

Claystone is indurated clay and silt that lacks fissility or lamination, but may possess bedding.

Marl is a partly consolidated sedimentary rock consisting of calcium carbonate and clay. If the material is more than 75 percent calcium carbonate, the rock is an argillaceous variety of limestone; if it is more than 75 percent clay, the rock is calcareous claystone or shale.

Chalk is a friable, fine-textured, and partly consolidated variety of limestone. If the material contains more than 25 percent clav, it is termed marl rather than chalk.

Shale is a fissile or laminated sedimentary rock containing predominantly clay- and silt-sized material of sufficient induration to remain coherent after wetting.

Calcareous shale is a laminated or fissile, very fine grained sedimentary rock that contains calcium carbonate ranging in amount from the minimum that can be detected by testing with dilute cold hydrochloric acid, to 25 percent: if there is more than 25 percent calcium carbonate, the rock is marl.

In general, the Pierre hardly deserves the name shale; parts of some members are shale in the sense defined above, but in central South Dakota the formation is predominantly claystone. The term Pierre shale has become so firmly established in the literature that an attempt here to refer to it only as the Pierre formation would be awkward and not in accord with general usage. Pierre shale will be used in this report as a formation name rather than as an overall description of its lithology.

The Pierre shale in the Pierre area does not contain the impressive macrofauna found in the formation at other places in the State. The barren middle zone of the Pierre shale at Fort Pierre was recognized by Meek and Hayden (1861) in the original description of the Fort Pierre group; the zone probably includes the Verendrye member and the lower part of the Virgin Creek member.

Essentially the only faunal study in the central part of the State that has been related to members of the Pierre shale was made by Searight (1937), who listed about 40 invertebrate fossils, principally cephalopods and pelecypods, and indicated their distribution within the formation. Subsequently he (Searight, 1938) studied the abundant microfauna of his Sully member 
(Crow Creek, DeGrey, and Verendrye members of this report).

Because of the general scarcity of fossils and poor preservation of the few forms that were found, a systematic attempt to collect and identify the Pierre shale fauna was not made in connection with this study; however, a brief note concerning the general fossil content is included in the discussion of each member.

The first comprehensive lithologic subdivision of the Pierre shale of central South Dakota was presented by Searight (1937) who also summarized previous attempts to subdivide the formation. The paper by Searight stands as the most significant contribution to an understanding of the stratigraphy of the Pierre shale in that region that has appeared to date.

Since Searight's (1937) subdivision, several changes (fig. 4) have been made both by workers of the State Geological Survey and by this author (Crandell, 1950). The subdivision for the Pierre shale now adopted by the U. S. Geological Survey for the Missouri River valley in central South Dakota is as follows:

Elk Butte member (at top)
Mobridge member
Virgin Creek member
Verendrye member
DeGrey member
Crow Creek member
Gregory member
Sharon Springs member (at bottom)

All except the Sharon Springs member crop out in the Pierre area.
The Virgin Creek, Mobridge, and Elk Butte members are lithologically distinctive units; distribution of the members, however, generally is limited to gently rolling upland areas where exposures, especially of contacts between members, are rare. The members therefore could not be separated for mapping purposes and the base of the Mobridge member is indicated on the geologic maps (pls. 1, 2, and 3) only where the contact is adequately exposed. Outcrops of the Elk Butte member are restricted to the Oahe quadrangle underlying upland areas at altitudes greater than 1,980 feet.

\section{SHARON SPRINGS MEMBER}

The name Sharon Springs was introduced by Elias (1931) for the basal member of the Pierre shale in western Kansas. Searight (Moxon, Olson, Searight, and Sandals, 1938, p. 136) recognized the lithologic similarity of Elias' member to the lower part of what he (Searight, 1937) had called the Gregory member. Accordingly he extended Elias' terminology to South Dakota by means of the following statement:

The underlying beds described as the lower Gregory are definitely contemporaneous with the Sharon Springs of Kansas (Elias, p. 58) . . . and the name is adopted for the beds between the Niobrara and the Gregory zone [Crow Creek member of present report] of the Sully as revised.

Searight did not further redefine the member; it is inferred that he considered that the former type section of the Gregory member, in Gregory County opposite Wheeler (fig. 1), subsequently would serve as the South

\begin{tabular}{|c|c|c|c|c|c|c|c|c|c|c|c|c|c|c|}
\hline & $\begin{array}{l}\text { Searight } \\
1937\end{array}$ & & $\begin{array}{l}\text { Searight } \\
1938\end{array}$ & \multicolumn{2}{|c|}{$\begin{array}{l}\text { Moxon and others } \\
1939\end{array}$} & \multicolumn{2}{|c|}{$\begin{array}{l}\text { Gries and Rothrock } \\
1941\end{array}$} & \multicolumn{2}{|r|}{$\begin{array}{l}\text { Gries } \\
1942\end{array}$} & $\begin{array}{c}\text { Crandell } \\
1950\end{array}$ & & $\begin{array}{c}\text { Curtiss } \\
1951\end{array}$ & \multicolumn{2}{|c|}{$\begin{array}{c}\text { Crandell } \\
1952 \text { aird this report }\end{array}$} \\
\hline \multicolumn{2}{|c|}{ Elk Butte member } & \multicolumn{2}{|c|}{ Elk Butte member } & \multicolumn{2}{|c|}{ Elk Butte member } & \multicolumn{2}{|c|}{ Elk Butte member } & \multicolumn{2}{|c|}{ Elk Butte member } & Elk Butte member & \multicolumn{2}{|c|}{ Elk Butte member } & \multicolumn{2}{|r|}{ Elk Butte member } \\
\hline \multicolumn{2}{|c|}{ Mobridge member } & \multicolumn{2}{|c|}{ Mobridge member } & \multicolumn{2}{|c|}{ Interior member } & \multicolumn{2}{|c|}{ Mobridge member } & \multicolumn{2}{|c|}{ Mobridge member } & Mobridge member & \multicolumn{2}{|r|}{ Mobridge member } & \multicolumn{2}{|r|}{ Mobridge member } \\
\hline \multicolumn{2}{|c|}{ Virgin Creek member } & \multirow{2}{*}{\multicolumn{2}{|c|}{$\begin{array}{c}\text { Virg!n Creek member } \\
\mid \begin{array}{c}\text { Verendrye-shale } \\
\text { zone }\end{array}\end{array}$}} & \multicolumn{2}{|c|}{ Virgin Creek member } & \multicolumn{2}{|c|}{ Virgin Creek member } & \multicolumn{2}{|c|}{ Virgin Creek member } & Virgin Creek member & \multicolumn{2}{|c|}{ Virgin Creek member } & \multicolumn{2}{|c|}{ Virgin Creek member } \\
\hline \multirow{3}{*}{ 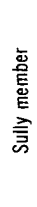 } & $\begin{array}{c}\text { Verendrye shale } \\
\text { zone }\end{array}$ & & & \multirow{4}{*}{ 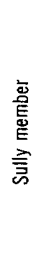 } & Verendrye zone & \multirow{4}{*}{ 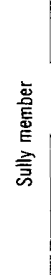 } & Verendrye beds & \multirow{4}{*}{ 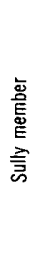 } & $\begin{array}{l}\text { Verendrye } \\
\text { member }\end{array}$ & 'Verendrye member & \multirow{4}{*}{ 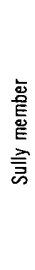 } & Verendrye facies & \multicolumn{2}{|c|}{ Verendrye member } \\
\hline & 0acoma zone & \multirow{3}{*}{ 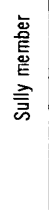 } & Oacoma zone & & Oacoma zone & & Oacoma zone & & \multirow{2}{*}{$\begin{array}{c}\text { Agency - 0acoma } \\
\text { zone }\end{array}$} & \multirow{2}{*}{ DeGrey member } & & Agency-Oacoma & 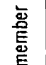 & $\begin{array}{c}\text { Shale and bentonite } \\
\text { facies }\end{array}$ \\
\hline & Agency shale & & Agency shale & & Agency shale & & Agency shale & & & & & facies & 产 & $\begin{array}{l}\text { Siliceous shale } \\
\text { facies }\end{array}$ \\
\hline \multirow{3}{*}{ 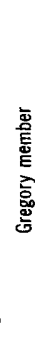 } & Upper & & Gregory marl & & Gregory marl & & $\begin{array}{l}\text { Crow Creek } \\
\text { sand and marl }\end{array}$ & & $\begin{array}{l}\text { Crow Creek } \\
\text { chalk and sand }\end{array}$ & Crow Creek member & & Crow Creek facies & & ow Creek member \\
\hline & \multirow{2}{*}{ Lower } & \multirow{2}{*}{\multicolumn{2}{|c|}{$\begin{array}{c}\text { Sharon Springs } \\
\text { member }\end{array}$}} & 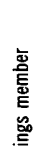 & Upper & 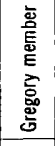 & $\begin{array}{c}\text { Shale zone } \\
\text { Marl zone }\end{array}$ & & iregory member & Gregory member & & iregory member & & Gregory member \\
\hline & & & & 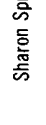 & Lower & 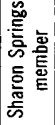 & $\begin{array}{c}\text { Upper } \\
\text { Lower }\end{array}$ & & $\begin{array}{l}\text { Sharon Springs } \\
\text { member }\end{array}$ & $\begin{array}{l}\text { Sharon Springs } \\
\text { member }\end{array}$ & & $\begin{array}{l}\text { Sharon Springs } \\
\text { member }\end{array}$ & & $\begin{array}{l}\text { Sharon Springs } \\
\text { member }\end{array}$ \\
\hline
\end{tabular}

FIguRe 4.-Summary of changes in the stratigraphic nomenclature of the subdivisions of the Pierre shale in central South Dakota since 1937. 
Dakota standard section of the Sharon Springs member.

Since 1938, the Sharon Springs member has been further restricted and redefined (fig. 4); these changes were discussed by Crandell (1950).

A detailed description of the Sharon Springs member could not be obtained from drill logs of the Corps of Engineers at the site of the Oahe Dam, other than the notation that the member includes 14 bentonite beds ranging from less than 1 to 18 inches in thickness. Searight's (1937, p. 11) description of the member, from the Gregory section, is as follows :

The lower part of the Gregory member [Sharon Springs member of this report] consists of a succession of beds typically composed of thin-bedded, flaky, dark, nearly black bitumenous [sic] shale, which becomes dark chocolate brown on exposure, interbedded with thin beds of bentonite.

Corps of Engineers drill logs indicate a thickness of about 115 feet for the Sharon Springs member at the Oahe Dam site, and Baker $(1947$, p. 11) records a thickness of 210 feet in a deep drill hole in the Oahe quadrangle (borehole 4, fig. 2). These thicknesses are much greater than that of any section measured along the outcrop of the member. Gries (1942) reported a thickness of 14 feet for the fish-scale-bearing beds (Sharou Springs member) at Crow Creek in southwest Buffalo County (fig. 1). At the mouth of White River, Gries measured 25 feet for the same interval. It is possible that some of the shale logged as Sharon Springs member in these drill holes should have been included in the Gregory member; the greater thickness, however, probably is caused by thickening of the member toward the west and northwest.

The northern limit of outcrop of the member is a few miles north of Crow Creek in Buffalo County. The Corps of Engineers drill logs show that the top of the member lies at an altitude of 1,255 feet at the Oahe Dam site, which is more than 150 feet below the surface of the Missouri River flood plain at that place.

\section{GREGORY MEMBER}

The Gregory member was defined by Searight (1937) to include the beds between the DeGrey member of this report and the Niobrara formation. With the subsequent recognition that the basal beds of the member were equivalent to the Sharon Springs member of Elias, Searight (1938) restricted the name Gregory to the Crow Creek member of this report and included it as the basal subdivision of his Sully member. Later, Gries and Rothrock (1941) split the Sharon Springs member of Searight, retained the name for only the basal part, and gave the name Gregory to the upper part (fig. 4).
The Gregory member of this report is the Gregory member of Gries and Rothrock (1941).

At the type section, the Gregory member consists of 9 feet of shale and marl overlain by 26 feet of gray shale and claystone. The base of the Gregory member lies at the contact of shale or marl with the underlying fish-scale-bearing bituminous shale of the Sharon Springs member. The top of the Gregory is at the contact of noncalcareous claystone with the calcareous basal siltstone of the overlying Crow Creek member.

The thickness of the Gregory member at the type section is about 35 feet. Gries (1942, p. 11) recorded a thickness of 125 feet " 8 miles up White River" ( 8 miles west of the confluence of the White and Missouri Rivers, fig. 1). At the Oahe Dam site, Corps of Engineers drill $\operatorname{logs}$ show a thickness of 177 feet for the member. It was suggested above that some of the basal beds of the Gregory might have been included in the Sharon Springs member in these logs.

Only the upper part of the Gregory nember crops out in the Pierre area. These beds consist of noncalcareous gray claystone. It was previously thought (Gries, 1942, p. 10,15) that the Gregory member crops out no farther northwest than about 12 miles east of Pierre. However, the uppermost 4 feet of the member have been recognized underlying the basal siltstone of the Crow Creek member adjacent to the Bad River, half a mile west of Fort Pierre. At this locality, the top of the Gregory lies at a maximum altitude of 1,425 feet. At the Oahe Dam site, the altitude of the top of the member ranges from 1,3̋0 to 1,400 feet. In the Canning quadrangle the top of the member occurs at altitudes ranging from 1,420 to 1,450 feet. In that quadrangle, exposures of the member are restricted to very small outcrops in the valley walls of the Missouri River and its tributaries. Because of the limited areal distribution of the Gregory member, it is undifferentiated from the overlying Crow Creek member on the geologic map (pl. 1).

The Gregory member is not known to contain macrofossils in the Pierre area, altho microfossils are present.

\section{CROW CREEK MEMLER}

The beds that form the Crow Creek member originally were those at the top of the Gregory member according to Searight (1937); subsequently the whole of Searight's (1938) Gregory member was made up of these beds. Gries and Rothrock (1941) later substituted the name Crow Creek sand and marl for the beds and assigned them, as had Searight (1938), to the Sully member. Crandell (1950) raised the rank of the unit to that of member. 


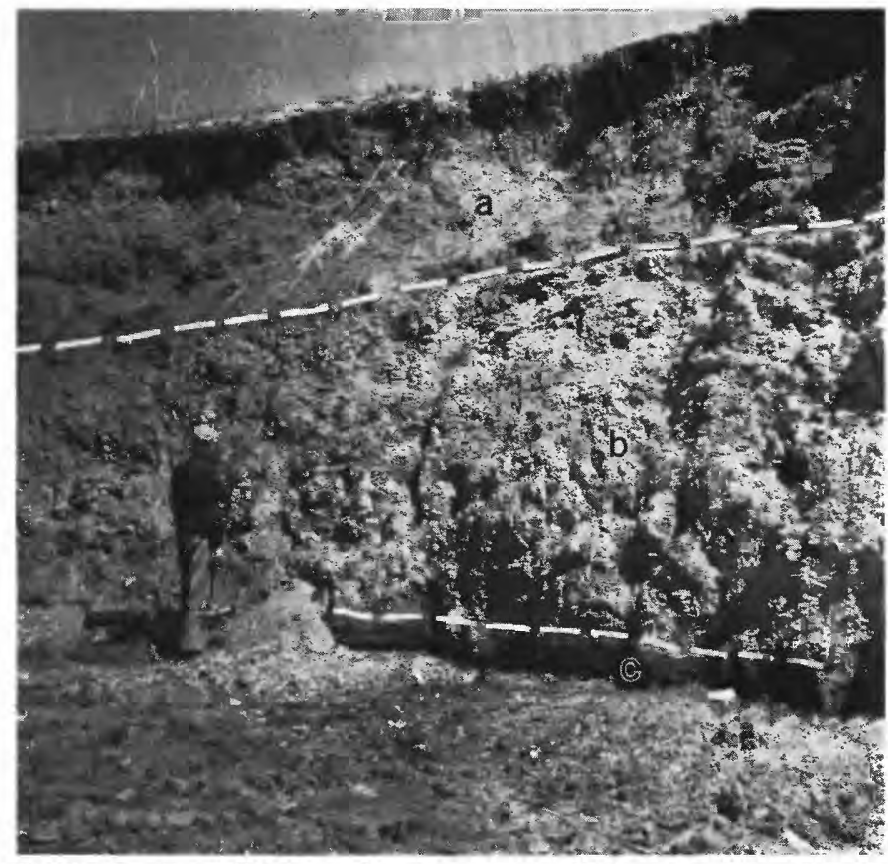

Figure 5.-Crow Creek member ( $b$, marl; $c$, siltstone) as exposed south of the Missouri River in the valley walls of Fort George Creek. Gregory member is beneath the ledge of siltstone, at base of bank: contact between the Crow Creek member and DeGrey member (a) is about 4 feet above the head of the man.

The origin of the Crow Creek member has been the subject of considerable discussion and speculation in the past; for this reason a special study was made of the member throughout most of its area of outcrop. The details of this investigation have been published elsewhere (Crandell, 1952b); only a summary of the results of the investigation are given here.

The Crow Creek member consists of a basal siltstone 10 to 15 inches thick and an overlying marl 7 to 10 feet thick, fig. 5). The marl ranges in color from light gray $(N \tau)^{1}$ where unoxidized to grayish orange $(10 Y R 7 / 4)$ where oxidized. Bedding or lamination has not been noted in the marl; it breaks into irregular blocks when struck with a hammer. The proportion of calcium carbonate in the marl ranges from 40 to 67 percent. In addition, there is a decrease in calcium carbonate content upward in the marl from about 65 percent at the base to about 45 percent at the top. Macrofossils have not been found in the Crow Creek member except for a few small fish teeth in the basal siltstone.

The siltstone is sandy near its base and calcareous and laminated. The laminations are caused by gently curved bedding surfaces that are related to grain-size variations. Nearly all exposures of the siltstone show foreset bedding. In most places this feature is re-

\footnotetext{
${ }^{1}$ Color values of the rocks are based on the Rock Color Chart distributed by the National Research Council, Washington, D. C.
}

stricted to the basal 1 to 3 inches of the layer. A sample of the siltstone taken from a drill core at the Oahe Dam site shows conspicuous cut-and-fill stratification about 4 inches above the base of the bed (fig. 6). The basal contact of the siltstone is disconformable and is marked by an abrupt lithologic change from noncalcareous claystone to calcareous sandy siltstone. Nowhere does there appear to be interbedding of claystone and siltstone, although locally a few grains of quartz have been observed in the uppermost $1 / 2$ to 1 inch of the Gregory member, and in some exposures the basal $1 / 2$ to 1 inch of the siltstone contains flakes of shale as much as 3 millimeters in largest dimension.

Cementation in the unweathered siltstone is poor and samples readily disaggregate after a short interval of soaking in tap water. In most outcrops, however, secondary iron oxides and gypsum have been deposited in the siltstone, thereby greatly increasing the consolidation of the layer. These secondary materials presumably have been derived from the overlying marl; the tendency of the marl to become yellowish brown on weathering probably is an expression of its iron content. Evidently the iron and calcium salts in the marl are taken into solution by ground water and then deposited in pore spaces in the siltstone. The presence of the relatively impermeable claystone of the underlying Gregory member favors deposition of calcium and iron compounds in the siltstone.

In the Pierre area, the siltstone is sandy only in the basal 6 inches; in this part of the layer the proportion consisting of sand-sized detrital mineral grains is less than 5 percent. The investigation of the siltstone throughout the outcrop area revealed an increase in proportion of sand-sized detrital mineral grains, particularly in the basal 1 to 7 inches of the bed, from the Pierre area toward the southeast.

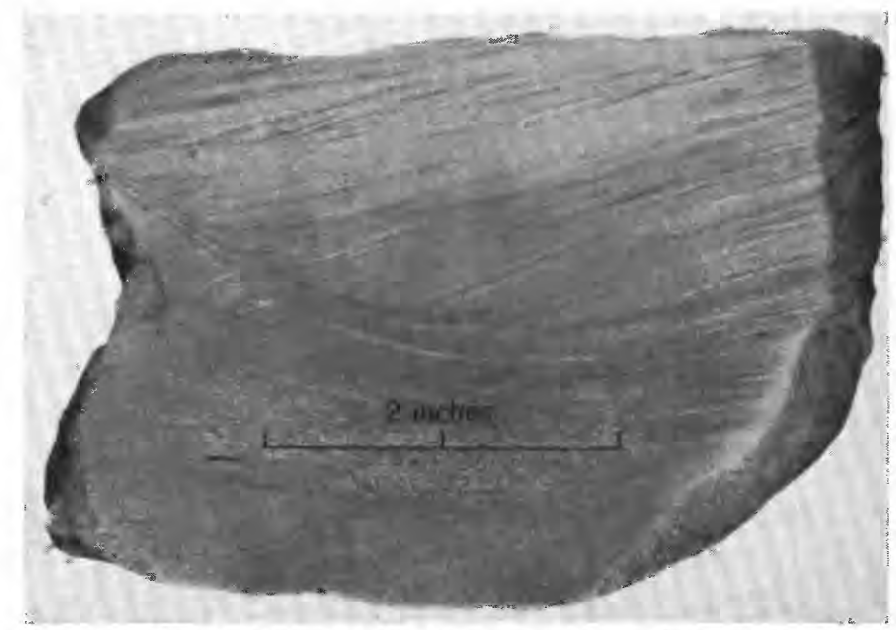

Figure 6.-Cut-and-fill stratification in siltstone of the Crow Creek member. Part of a core from a Corps of Engineers drill hole at the Oahe Dam site. 
The calcareous and coarse-grained nature of the Crow Creek member implies a change in environmental conditions from those in which the Gregory member was deposited. The following two lines of evidence indicate that the Crow Creek member was deposited in shallow water.

The sharp transition from noncalcareous claystone to calcareous siltstone and marl implies an abrupt change in physical and chemical conditions. The solubility product of calcite is directly related to the amount of carbon dioxide in the water and this product decreases with rising temperature (Johnston and Williamson, 1916, p. 731). Thus, precipitation of calcium carbonate is favored where the temperature of lime-bearing water is increased-a condition most commonly occuring in shallow seas, where the temperature of the surface water is high. Shallow water also is necessary to insure that the lime will not have to settle through colder water and thereby go back into solution before it reaches bottom.

The fossil evidence ${ }^{2}$ is consistent with the hypothesis of a shallow-water origin of the member. The upper beds of the Gregory member contain a fauna of Radiolara including the genera Dictyomitra and Tricolapsa; D. multicostata is the most common species. No Foraminifera were noted. The lowest 2 to 5 feet of the marl contains a foraminiferal fauna of both benthonic and pelagic forms. The overlying marl contains few Foraminifera, and those few were predominantly pelagic forms (Globigerina and Gumbelina) and they are noticeably smaller in size than those in the marl below. In these upper marl beds, Radiolaria of the genus Dictyomitra are present but rare. In the basal few feet of the DeGrey member, both pelagic Foraminifera and Radiolaria are present, but the Radiolaria are more abundant. This stratigraphic distribution of Foraminifera and Radiolaria lends support to other evidence suggesting a transition from deeper, cooler water to shallower, warmer water, and back to deeper water again.

Because of the presence of Foraminifera, it seems certain that the Crow Creek member is wholly of marine origin. The cut-and-fill stratification in the siltstone in at least one place suggests that submarine currents were powerful enough to channel the material after original deposition. These currents were very likely the chief transporting agent for the sediment that formed the siltstone.

\footnotetext{
2 This discussion of the microfossils of the Gregory, Crow Creek, and DeGrey members was made possible by a preliminary investigation by by K. M. Waagé (written communication, Feb. 13, 1952) of samples submitted by the writer.
}

The abrupt change of grain size from the Gregory member to the Crow Creek member indicates a sudden influx of coarse material. This change corresponds to the appearance of limy material. The large proportion of clay in the Crow Creek member, however, indicates that all the conditions leading to the deposition of the underlying claystone of the Gregory member were not changed. In other words, clay continued to be deposited but calcium carbonate and coarser material were added.

The study of grain-size distribution of the siltstone indicates that the coarse material in it was derived from an area southeast of the Pierre area. Essentially nothing is known about the location of the eastern shoreline of the Late Cretaceous epeiric sea at the time the Crow Creek member was deposited.

It seems likely that a Late Cretaceous uplift of an area in east-central South Dakota caused a reworking of sediments that previously had been deposited over it. This hypothesis supposes that the Niobrara formation, if originally continuous in that area, was removed by subaerial or subaqueous erosion. Coarser material could have been derived from sandstone beds in the underlying Carlile shale. The postulated uplift responsible for the reworking of older formations is consistent with the evidence demanding a contemporaneous shallowing of the adjacent sea floor to allow deposition of calcium carbonate.

\section{DEGREY MEMBER}

The DeGrey member was defined by Crandell (1950) to include the beds between the top of the Crow Creek member and the overlying gumbo-forming claystone of the Verendrye member. The member thus includes the Oacoma zone and the Agency shale of Searight (1937).

Searight differentiated between the Agency shale and the Oacoma zone because of the external characteristics of the rocks. He described the Agency shale as consisting of hard light-gray siliceous shale and the overlying Oacoma zone as beds of highly bentonitic shale and clay containing "manganiferous iron concretions". Gries (1940, p. 18) arbitrarily chose the base of a distinctive bentonite bed as the horizon separating the two units of Searight.

In 1942, Gries recognized that the Oacoma unit of Searight at the type section included beds below that assumed to be the base of the same unit at Fort Pierre. He suggested that the lower beds of the Oacoma unit in the area of the type section thicken northward and form the Agency unit. $\mathrm{He}$ further noted that the distinctive bentonite bed chosen as the base of the Oacoma in Stanley County was recognized 72 feet 
below the top of the Agency unit at Cheyenne Agency, and concluded that

the Oacoma zone as defined by Searight included ... part, if not all, of the Agency zone. Inasmuch as it is not possible to draw the line between the true Agency and the banded beds in the type locality of Searight's Oacoma zone, it is here suggested that both terms be retained, and that all beds lying between the Crow Creek chalk and the base of the Verendrye zone be hereafter referred to as the Agency-Oacoma zone.

If Gries' correlation of the distinctive bentonite bed from northeastern Stanley County to Cheyenne Agency is valid, it is evident that the Agency shale of Searight transgresses a time horizon. Gries' use of this fact to justify combining the Agency and Oacoma of Searight into one unit suggests that he thought that lithologic units should also be time units insofar as possible. In other reports, however, Gries (1939, 1940) consistently and correctly defined and discussed members of the Pierre shale in a purely lithologic sense. On the basis of the time consideration alone, Gries was not justified in making one unit of Searight's two.

Gries' suggestion that the two parts be combined into one was accepted by Crandell (1950) because this one unit appears to be lithologically distinct from the members above and below. Minor lithologic variations are recognized within this unit and are considered facies of insufficient importance in the Pierre area to merit setting apart as separate members.

The DeGrey member is predominantly light-olivegray shale and claystone. The beds in the basal 125 feet of the member are moderately siliceous and comprise what is informally referred to as the siliceous shale facies of the member. This facies is the approximate stratigraphic equivalent of Searight's Agency shale. The upper 30 to 75 feet of the member includes about 25 bentonite beds and is, therefore, informally referred to as the shale and bentonite facies of the member. This facies is the approximate stratigraphic equivalent of Searight's Oacoma zone.

The shale and claystone of the siliceous shale facies are generally well consolidated and clink or ring when pieces are struck together. Outcrops of the facies commonly are partly covered with a thin film of grayishbrown to very dusky red-purple material. The film likely consists of oxides of iron and manganese derived from weathering of disseminated iron and manganese carbonate in the shale.

A distinctive bentonite bed, ranging in thickness from 4 to 6 inches, occurs about 10 feet above the base of the DeGrey member. The bentonite is characteristically mottled green and gray, ranging from greenish gray $(5 G 6 / 1)$ to light greenish gray $(5 G 8 / 1)$. The layer contains a heavy concentration of biotite flakes that range from 0.1 and 0.5 millimeter in largest dimension and sand-sized grains of plagioclase $\left(\mathrm{An}_{30}\right)$. These mineral fragments were very likely phenocrysts in the volcanic ash from which the bentonite was derived (see Rubey, 1929, p. 160).

The shale and bentonite facies consists of interbedded claystone, shale, and layers of bentonite (fig. 7 ). The shale and claystone are generally well consolidated. Several bentonite beds in the facies are so distinctive that they can be traced continuously through distances of many miles. The lowermost of these was designated the lower micaceous bentonite by Gries (1940, p. 18), who described this layer as ranging in thickness from 4 to 6 inches and as bearing abundant biotite flakes as



FIGURE 7.--Outcrop of DeGrey and Verendrye members in the valley walls of Antelope Creek in $\mathrm{NE}^{1 / 4} \mathrm{NW}^{1 / 4}$ sec. 17, T. 4 N., R. $33 \mathrm{E}$. Man is at contact of siliceous shale facies (c) and shale and bentonite facies (b). Iight-colored layers in shale are bentonite beds, Contact between DeGrey member and overlying Verendrye member $(a)$ is about 6 feet above the uppermost visible bentonite bed. 
much as 1 millimeter in diameter. The bentonite bed also contains sand-sized grains of plagioclase $\left(\mathrm{An}_{35}\right)$ and muscovite and silt-sized particles of apatite. The layer is made up of material of several colors, among which are pale greenish yellow (10 $Y 8 / 2$ ), yellowish gray $(5 Y T / 2)$, dark yellowish orange $(10 Y R 6 / 6)$, and light olive gray $(5 Y 6 / 1)$. This bentonite bed is readily located because weathering of the biotite forms a rustcolored iron oxide stain on outcrops. In the Pierre area, the lower micaceous bentonite of Gries forms the approximate base of the shale and bentonite facies.

The shale and bentonite facies of the DeGrey member contains abundant fragments of pelecypods although well-preserved specimens are rare. While mapping the Pierre quadrangle, the author observed fragments or whole specimens of mosasurs at more than a dozen localities (fig. 8). Two of these specimens were examined by D. H. Dunkle (written communication, October 5, 1948) who identified them as Platecarpus cf. brachycephalus Loomis. Dunkle identified another vertebrate fossil collected from the shale and benonite facies as the marine turtle Archelon cf. ischyros Wieland. Macrofossils were not found in the siliceous

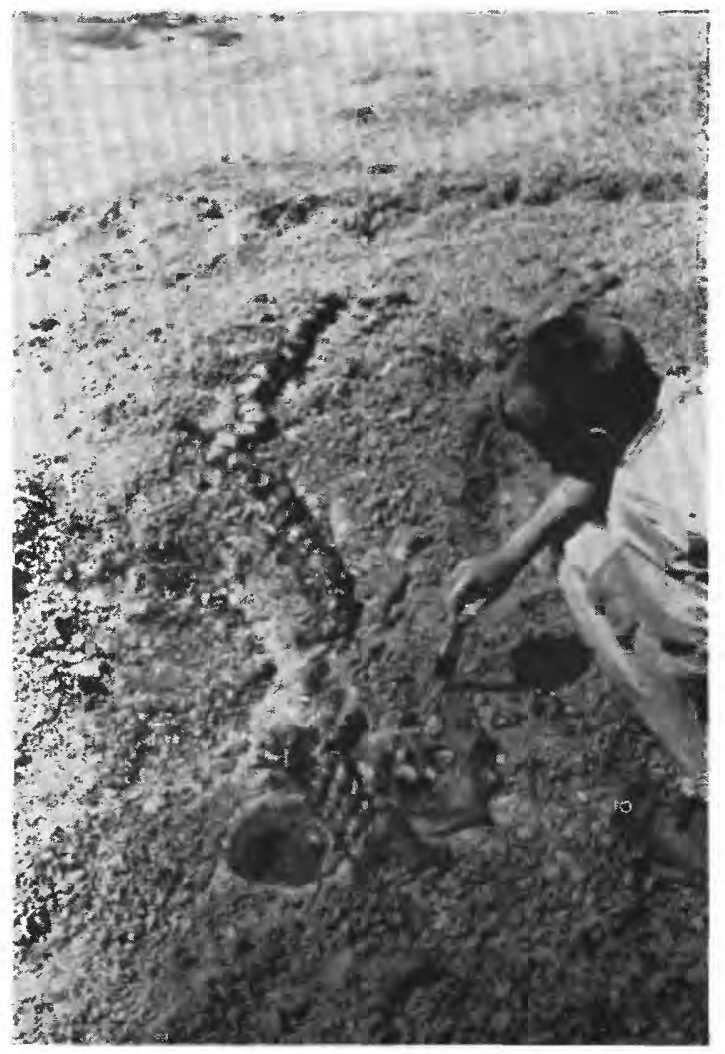

Figure 8.- Specimen of the mosasaur Platecarpus cf. brachycephalus Loomis in the shale and bentonite facies of the DeGrey member in NE $1 / 4$ sec. 35, T. 112 N., R. 80 W. near the east end of Peoria Bottom. shale facies of the member. The microfauna of the DeGrey and Verendrye members (the Sully member of Searight) has been described by Searight (1938).

From southeastern Lyman County northward to DeGrey in southeast Hughes County, the shale and bentonite facies of the DeGrey member contains abundant iron manganese carbonate concretions. The concretions range from 1 to 6 inches in longest dimension and are most commonly very dark purple. From a distance, outcrops of the member appear nearly black owing to a blanket of concretions that have weathered from the inclusing shate and now lie on the surface. The concretions generally contain fragments of pelecypods and fossil casts of iron manganese carbonate are common. From DeGrey westward, the abundance of concretions decreases progressively. They are relatively uncommon at Pierre.

$\Lambda$ second type of concretion consists of large spherical masses of limestone, as much as 3 feet in diameter. Random samples of two of these concretions contained 17 and 13.5 percent material insoluble in dilute hydrochloric acid. The concretions are yellowish gray $(5 Y 7 / 2)$ where fresh, but weather to moderate brown $(5 Y R 3 / 4)$. They disintegrate into angular pieces when struck with a pick, although near Pierre they commonly weather to subparallel plates, 1 to 3 millimeters thick. In the Canning quadrangle, the spherical concretions occur in a remarkably persistent bed about 10 feet below the top of the member; at Fort Pierre, they are found 15 feet below the top, and at the west edge of the Pierre quadrangle, 33 feet below the top of the member. From Fort Pierre westward, transitional beds, 15 to 33 feet thick, that contain numerous thin bentonite layers occur between the limestone concretions and the typical basal beds of the Verendrye member. These transitional beds are here assigned to the DeGrey member.

The DeGrey member is about 160 feet thick at Pierre. The shale and bentonite facies is about 35 feet thick and the siliceous shale facies, 125 feet thick. Toward the west the shale and bentonite facies thickens to 75 feet; whether there is a corresponding thickening in the underlying facies is not known. Eastward from Pierre there is a decrease in thickness of the member to the east edge of the Canning quadrangle where a maximum of 125 feet has been recorded. At the type section of the DeGrey member, 6 miles east of the east edge of the Canning quadrangle, the total thickness of the member is only 82 feet. At this place, the shale and bentonite facies is 34 feet thick. Accordingly it appears that the thinning has occurred at the expense of the siliceous shale facies. 
VERENDRYE MEMBER

Searight (1937, p. 25) originally gave the name Verendrye (pronounced ver-én-dree) zone to the beds immediately overlying the so-called Oacoma zone (shale and bentonite facies of the DeGrey member of this report). He considered these beds to be a subordinate part of his Sully member. The Verendrye zone of Searight was raised to the rank of a member by Crandell (1950).

The Verendrye member consists predominantly of 140 to 160 feet of light-olive-gray $(5 Y 6 / 1)$ to olivegray $(5 Y 4 / 1)$ claystone. The member weathers first to soft flakes and chips and then to light-olive-gray $(5 Y 5 / 2)$ or brownish-gray $(5 Y R 4 / 1)$ gumbo. The cover of gumbo, from several inches to several feet thick, conceals stratification on outcrops. However, bedding from 2 to 8 feet thick is noticeable on outcrops where a color banding of dark yellowish brown and olive gray $(5 Y 5 / 2)$ has developed. The bands evidently reflect differences in composition of the underlying beds because some of the bands are barren of vegetation whereas others support some plant life.

Concretions of several types are abundant in the Verendrye member. One type is chiefly round, oval, or kidney-shaped, ranging in thickness from 1 to 6 inches, and in maximum diameter from 1 to 3 feet. Gries (1942, p. 19) referred to these as iron-manganese carbonate concretions. The concretions have a rind of dusky-red-purple material ranging from one-eighth to half an inch thick. The core is dark yellowish orange to light olive gray (5Y6/1). Neither the core nor the rind reacts to dilute cold hydrochloric acid, although, when powdered, the material forming the core effervesces weakly. Many of the concretions are broken by a series of joints; each segment so formed consists of a weathered rind and a core of unweathered material. Kidney-shaped concretions commonly lack this segmentation and are formed of one massive piece of material that shows a comparable separation into rind and core.

A second type of concretion appears to have been formed by the filling of the living chamber of a baculite. These are commonly 6 to 16 inches in length and 1 to 3 inches in diameter. In color and composition they appear to be identical with the concretions described above. Some are bounded on one end by the characteristic undulating septal surface of the original baculite.

The Verendrye member is typically unfossiliferous in the Pierre area although fragments of Baculites compressus were found locally. Isolated bones of marine reptiles also were noted at a few places, but it is pos- sible that these were washed downslope from the Virgin Creek member.

The base of the member in the Pierre area is marked by a change in lithology from claystone to the shale, claystone, and bentonite beds of the DeGrey member. Although this change is readily apparent from a distance of several hundred yards from the outcrop (fig. $9)$, on closer examination a well-defined surface of separation between the two members is lacking, and, there is a gradational contact zone 10 to 30 feet thick instead.

IIRGIN CREEK MEMBER

The Virgin Creek member was originally described by Searight $(1937$, p. 35) as consisting of the beds between the Verendrye "zone" and all "characteristically non-calcareous beds to the base of the Mobridge". The present usage of the name is essentially that of Searight.

The member consists of olive-gray to light-olive-gray shale and claystone with intercalated beds of bentonite. The thickness ranges from 120 feet in the Canning quadrangle to 230 feet in the Oahe quadrangle. The lower 80 to 90 feet of the member is predominantly shale that, on weathering, disintegrates into thin flakes. This part of the member contains 15 or more bentonite beds ranging in thickness from a fraction of an inch to $61 / 2$ inches. The upper part of the member consists predominantly of claystone that breaks down to gumbo on weathering without going through an intermediate flaky stage as do the lower beds. The uppermost 25 to 50 feet of the member are locally calcareous, although the appearance of these beds is not different from that of the underlying noncalcareous beds. Bentonite beds less than 1 inch thick occur sporadically throughout the upper part of the member.

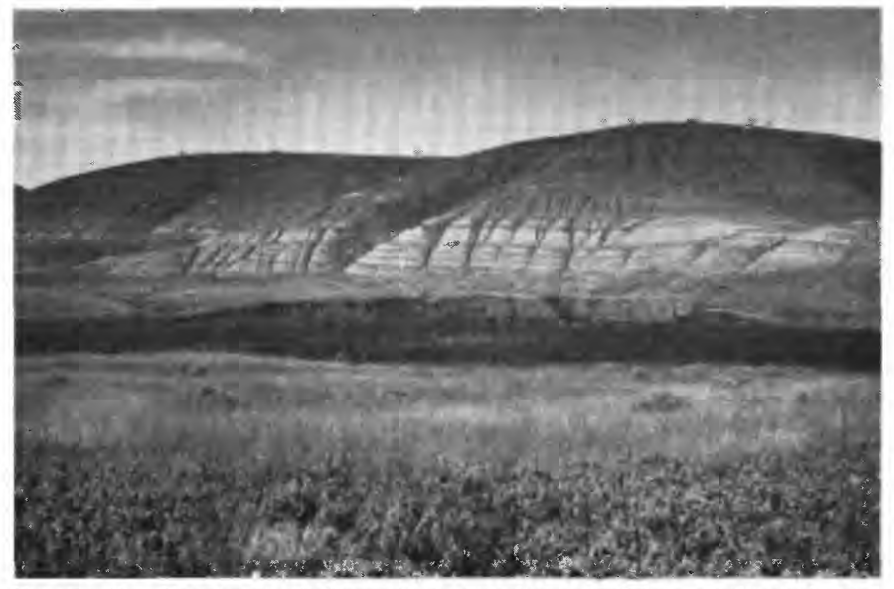

Figure 9.-Exposure of Verendrye member overlying shale and bentonite facies of DeGrey member in NE1/4 NW1/4 sec. 10 , T. $6 \mathrm{~N}$., li. 2!) E. near the mouth of Chantier Creek. 
Concretions of several types are found in the Virgin Creek member. One consists of a hollow cylindrical concretion of light-gray limestone about three-fourths inch in diameter and from 2 to 6 inches long. Elias (1931) thought it probable that these were worm tubes, but Gries (1939, p. 26) suggested that they are related in origin to some kind of plant. Gries noted that these concretions are restricted to the upper part of the member, but they have been found near its base in the northern part of the Pierre quadrangle. Another type of concretion is a small egg-shaped mass of light-gray limestone perforated with small holes. Russell (1930, p. 3-4) suggested that these holes were formed by worms. Limestone concretions as large as 1 foot in diameter occur at horizons in both the upper and lower part of the Virgin Creek member.

Fossils found in the lower part of the Virgin Creek member include Belemitella bulbosa, Baculites sp., and the crab Dakoticancer overana Rathbun. In addition, the author has colleced the pelecypod Inoceramus tenuilineatus IIall and Meek from limestone concretions near the base of the member in the southwestern part of the Pierre quadrangle. In the upper part of the member, belemnites and fragments of baculites are found locally, but nowhere are they abundant. Vertebrae of marine reptiles, probably mosasaurs, are common, although bones in place were not found. The single vertebrae fossil found in place was identified by D. H. Dunkle as the caudal fin assemblage of a chirocentrid fish. He stated (written communication January 8,1953 ) that the family to which this form belongs includes genera known from the Sharon Springs member of the Pierre shale.

The base of the Virgin Creek member lies where there is a change from shale that weathers to brittle flakes and chips to claystone of the underlying Verendrye member that weathers to gumbo. This change is at the lowermost layer of a group of bentonite beds in the lower part of the Virgin Creek member. At the base of the member, concretions of barite impregnated with iron oxide locally make a continuous bed that forms a resistant ledge in gullies cut into the contact. In spring and early summer, seeps and moist areas are locally present at and just below the base of the Virgin Creek. Efflorescent white salts commonly form on the surface of the Verendrye member immediately downslope from these seeps; a sample of these salts from sec. 11, T. 4 N., R. 30 E. was identified as epsomite, hydrous magnesium sulfate.

The top of the Virgin Creek is marked by a change in lithology from noncalcareous (locally slightly calcareous) gray claystone to highly calcareous grayishorange shale of the Mobridge member.
The Virgin Creek member lies beneath a major portion of the upland surfaces south and west of the Missouri River in all three quadrangles. North and east of the Missouri, it crops out only where the contact of the glacial drift and shale is at an altitude of more than 1,720 feet. The member forms the bedrock cores of both Snake Butte and Medicine Knoll. In the former the member crops out up to a contact with glacial drift at an altitude of about 1,830 feet. The Virgin Creek member extends to an altitude of about 1,810 feet in the east and north sides of Medicine Knoll.

MOBRIDGE MEMBER

The Mobridge member was defined by Searight (1937, p. 44) as

a succession of highly calcarious [sic] shale, marl, and chalk beds which lies above the gumbo forming shales of the Virgin Creek member and below the non-calcareous shale beds of the Elk Butte member.

Sereral terms have been used to describe the lithology of the member. Searight (1937, p. 44-45) applied to it the names chalk, calcareous shale, marl, and limestone. In the Pierre area, the member consists predominantly of partly indurated calcareous shale. The proportion of calcium carbonate, determined by dilute hydrochloric acid treatment of spot samples from several localities, ranges from 15 to 27 per cent. The shale tends to part along the surfaces of laminations, ranging in thickness from one-sixtieth to onetenth inch. Although the member is gray where unoxidized, on weathered outcrops it is grayish orange or buff.

Moxon, Olson, and Searight (1939, p. 57) noted that selenium in unusual amounts appears to be associated with calcareous sedimentary rocks. It was stated that sufficient selenium is present in the Mobridge member in Stanley County to produce soils that support toxic vegetation. The selenium content in this area ranges from 1.5 to $5.0 \mathrm{ppm}$.

Moxon, Olson, and Searight (p. 58) inferred that there is a genetic association between calcium carbonate, sulfides, selenium, and organic matter, and concluded that

areas of Cretaceous sea bottom on which organic matter was accumulating in unusual amounts were the sites of greater reduction that [than] elsewhere and that as a result greater amounts of calcium carbonate, sulfide, and selenium were deposited.

Searight (1937, p. 43) pointed out that the contact, between the Mobridge and Virgin Creek members is readily defined in many places because the overlying Mobridge member is relatively resistant and a pronounced color change from dark gray to yellow or buff occurs. 
Subsequently he recognized (Moxon, Olson, and Searight, 1939, p. 47) 10 feet of calcareous shale that contains several thin beds of "nearly pure chalk" near the top of the Virgin Creek member in Lyman and Stanley Counties.

The presence of the calcareous shale below what Searight termed Mobridge has proved to be a source of confusion to later workers who attempted to locate the contact of the Mobridge and Virgin Creek members. This problem was discussed by Gries (1940, p. 3334 ). Because Gries adequately described relationships that have been noted by the present author, his discussion is quoted below.

Buff shale beds, separated from the underlying gras shale by a sharp line of demarcation, are conspicuous on some of the bare knolls close to the breaks. Because of their resemblance to the Mobridge beds described by Searight, they were carefully examined. At the base is a persistent bed of small $\left(1^{\prime \prime}-3^{\prime \prime}\right)$ rusty looking concretions which are, in nearly all cases. casts of segments of baculites. Tests with acid reveal that not only were the buff beds calcareous, but that up to forty feet of the underlying gray shale was more or less calcareous, also. Because the buff beds contained such fossils as Belemnitella, and were evident only on isolated and well weathered points, it was concluded that they may be only a weathering phase of the Upper Virgin Creek. It is quite possible, however, that these upper beds belong to the overlying Mobridge member. If the Mobridge must be distinguished from the upper Virgin Creek primarily by its calcareous nature, the contact in this case can be determined only by acid tests, for the shale above and below the dividing line appears identical as to lithology, color and weathering. If the zone of small concretions be taken as the contact, the calcareous or non-calcareous criterion must be abandoned, as must the change from gray to yellow weathering beds, for the beds above the zone weather yellow only upon extended weathering. A possible criterion, judging from limited observations, is that the beds below the zone of rusty concretions weather to gumbo, those above may not. Pending further study, this entire section is classified as upper Virgin Creek.

Gries (1942, p. 26) subsequently reversed his earlier opinion, and in reference to the contact of the Mobridge and Virgin Creek members in northeastern Stanley County, stated that

the uppermost Upper Virgin Creek is calcareous, and the contact with the Mobridge chosen at a layer of rusty brown baculite casts at the base of the yellow weathering calcareous shale which forms the higher parts of the upland surface.

The author shares this later opinion of Gries. It is believed that an important feature in the shale beds described is the bed of "rusty looking concretions" at the contact of the "buff" beds and the underlying gray shale. Segments of baculites and fragments of mosasaur bones have been found by the author in this layer. This concentration of fossils contrasts markedly witls the beds above and below in which the occurrence of invertebrate macrofossils is sporadic. It seems likely that an important change in environment occured in the interval represented by the fossil concentration. The presence of predominantly highly calcareous shale above and shale that is noncalcareous or only slightly calcareous below lends support to the validity of this suggestion. The base of the Mobridge member thus is here defined as the contact between calcareous shale that weathers to a grayish-orange ("buff") color and somewhat calcareous shale that weathers gray. This contact is further marked by the layer of segments of baculites and concretions stained with iron oxide.

In the Pierre area the thickness of the Mobridge member has not been determined with accuracy. In the Canning quadrangle, a maximum thickness of 25 feet has been measured, but the top of the member has been removed by erosion. In the north-central part of the Oahe quadrangle, the member is about 30 feet thick; in the westem part it may be as thick as 100 feet. Searight (1937, p. 49) recorded a thickness of 190 feet for the member adjacent to the Bad River 20 miles west of the Oahe quadrangle.

In the Canning quadrangle and at many places in the Oahe quadrangle, the Mobridge member caps high knobs and ridges. The known distribution of the mem. ber is restricted to the Oahe quadrangle and to small outcrops in the southem part of the Canning quadrangle. Three miles south of the Pierre quadrangle, in sec. 31, T. 109 N., R. 79 W., an outcrop of the member lies at an altitude of 1,875 feet. In the southwest corner of the Pierre quadrangle, the ground surface has a maximum altitude of about 1,910 feet, but outcrops of the Mobridge member have not been identified in this area. Several auger holes were drilled to a depth of 8 feet without locating beds that resembled the Mobridge. In an artificial cut made in excavating for a cattle pond in sec. 12 , T. 3 N., R. 30 E., about one mile south of the southwest corner of the Pierre quadrangle, only the gray, noncalcareous claystone of the Virgin Creek member is exposed at an altitude of 1,915 feet. Thus it seems that the Mobridge member has been entirely removed from the Pierre quadrangle by erosion. Although the altitude of Medicine Knoll in the Canning quadrangle is great enough to include the Mobridge member, if this member does occur there it is buried beneath glacial drift. In the Oahe quadrangle the Mobridge occurs on high knobs and ridges that extend to altitudes ranging from 1,940 to 2,070 feet. The member crops out along the breaks west of Peoria Bottom and underlies much of the upland surface in the northwestern part of the quadrangle. 


\section{ELK BUTTE MEMBER}

The Elk Butte member was first defined by Searight (1937, p. 50) as shale that occurs between the top of the "calcareous chalky, buff weathering shales of the Mobridge member" and the base of the Fox Hills formation.

In the Oahe quadrangle, noncalcareous shale and claystone overlie the Mobridge member. These beds are here correlated with the Elk Butte member on the basis of their lithology and stratigraphic position, although the member heretofore has not been identified in eastern Stanley County.

The Elk Butte nember consists of noncalcareous light-olive-gray shale and claystone. The most distinctive feature of the member in the Pierre area is the occurrence of dark-yellowish-orange to moderate-yellowish-brown calcareous concretions. They are round, 6 inches or less in diameter, and are about 1 inch thick. The concretions are especially common in the lower part of the member; whether they occur throughout the member is not known. Macrofossils were not seen in the member in the Pierre area.

The contact of the Elk Butte and Mobridge members has not been observed although it has been located in several places within 10 or 15 feet vertically. The contact used to delimit the two members is the line of division between the grayish-orange-weathering shale of the Mobridge and the gray gumbo-forming beds of the Elk Butte member.

At an altitude of 2,000 to 2,100 feet in the $\mathrm{NW}^{1} / 4$ sec. 6 , T. 4, N., R. 29 E., beds stratigraphically higher than the typical gray claystone of the Elk Butte member are fissile, slightly calcareous, and weather grayish orange. Although the characteristic concretions of the lower part of the member are not present in these higher beds, the slightly calcareous beds probably are part of the Elk Butte member. The possibility remains, however, that these higher beds are a shale facies of the Fox Hills sandstone of Late Cretaceous age. Except for this possibility, the uppermost beds of the Elk Butte member have been eroded from the area; the maximum thickness that remains is about 160 feet.

ENVIRONMENT OF DEPOSITION OF THE PIERRE SHALE

In Late Cretaceous time, epeiric seas bordering the Rocky Mountain geosyncline extended eastward into Minnesota and Iowa (Dumbar, 1949, p. 360). The Upper Cretaceous sediments of this geosyncline attain a maximum thickness of nearly 20,000 feet in southwest Wyoming (Reeside, 1944), where coarse clastic nonmarine sedimentary rocks predominate. These rocks grade into and intertongue eastward with marine sediments. Still farther east, the formations in the
Montana group are wholly marine (Stephenson and Reeside, 1938). At Pierre the Upper Cretaceous rocks. are nearly 2,000 feet thick; half of this thickness consists of Pierre shale.

The Pierre shale and the Fox Hills sandstone are members of the entirely marine eastern sequence. To the northwest, in central Montana, the Pierre shale is partly replaced by the Judith River formation of flood-plain and deltaic origin.

During deposition of the Pierre shale the Pierre area probably lay 200 to 300 miles west of the eastern shoreline of the Late Cretaceous epeiric sea. Evidence is lacking that the Pierre area ever was above sea level during deposition of the Pierre shale, although the sea probably was shallower during deposition of the Crow Creek and Mobridge members than during deposition of the other Pierre shale members.

The many bentonite layers in the Pierre shale may have some envirommental significance. J. E. Todd (Condra, 1908, p. 13) first suggested that bentonite is derived from volcanic ash, and Hewett (1917) subsequently found supporting evidence for this mode of origin in bentonite layers in the Cretaceous rocks of the Bighorn Basin, Wyo. Many of the bentonite beds studied in the Pierre area, particularly those in the lower part of the Virgin Creek member and in the upper part of the DeGrey nember, are sharply set apart from the enclosing rock. Other bentonite beds appear to be mixtures of bentonite and mud. At still other places in the section, bentonite is disseminated throughout the shale. The bentonite layers of the DeGrey member are mostly of the first type; those of the Virgin Creek member are separated by shale that contains disseminated bentonite. In addition to the bentonite that can be observed as bedded or dissiminated yellow material in the shale, each member of the Pierre that crops out in the area mapped contains clay minerals of the montmorillonite group that can be readily detected with the benzidine test.

The sharpness of contact and purity of many bentonite beds suggest that the volcanic ash fell to the water surface and settled to the bottom relatively rapidly. If a long time had elapsed, the ash would likely have been mixed with mud. The sharpness of contacts between bentonite and shale indicates that the material was not reworked after it had settled to the bottom of the sea. This leads to the inference that the volcanic ash layers accumulated in quiet water below the bottom-disturbing effect of waves. The implication seems to be that at least part of the Pierre shale accumulated in rather deep water.

Rubey (1930, p. 40-43) applied the same reasoning to a study of bedding laminations noted in Upper 
Cretaceous formations in the Black Hills region. $\mathrm{He}$ concluded that "the sea was probably relatively deep near the present Black Hills." Because of an inferred more uniform climate in Late Cretaceous time than now, Rubey added that wind velocities would have been less than now, and that wave base would have been correspondingly shallower. He suggested further (p. 51) that the nonlaminated mudstones in the Pierre shale and the nonlaminated marl in the Niobrara formation probably accumulated in relatively shallow water or at times when wave base was deeper than usual.

The member of the Pierre shale in which lamination is most apparent is the Mobridge. The precipitation of calcium carbonate previously noted, is favored by a shallow bottom. The calcareous nature of the Mobridge member indicates a shallow bottom but the lamination suggests that the member accumulated below wave base. It appears likely that an unusually uniform environment must have prevailed during deposition of the member to prevent the formation of large waves which would churn up bottom sediments. Conversely, the total lack of bedding in the marl of the Crow Creek member might imply deposition on a shallow bottom subject to disturbance by waves.

\section{FOX HILLS SANDSTONE}

Upper Cretaceous rocks younger than Pierre shale are not known to crop out in the Pierre area. The nearest known outcrops of the Fox Hills sandstone are nearly 50 miles northwest and 75 miles west of the Oahe quadrangle (fig. 10).

In a road cut adjacent to U. S. Highway 83, about 20 miles south of Fort Pierre and about 8 miles north of Vivian (fig. 1), the ammonites Discoscaphites nicolleti (Morton) and Discoscaphites conradii (Meek) were collected from limestone concretions that are enclosed in gray shale and claystone.

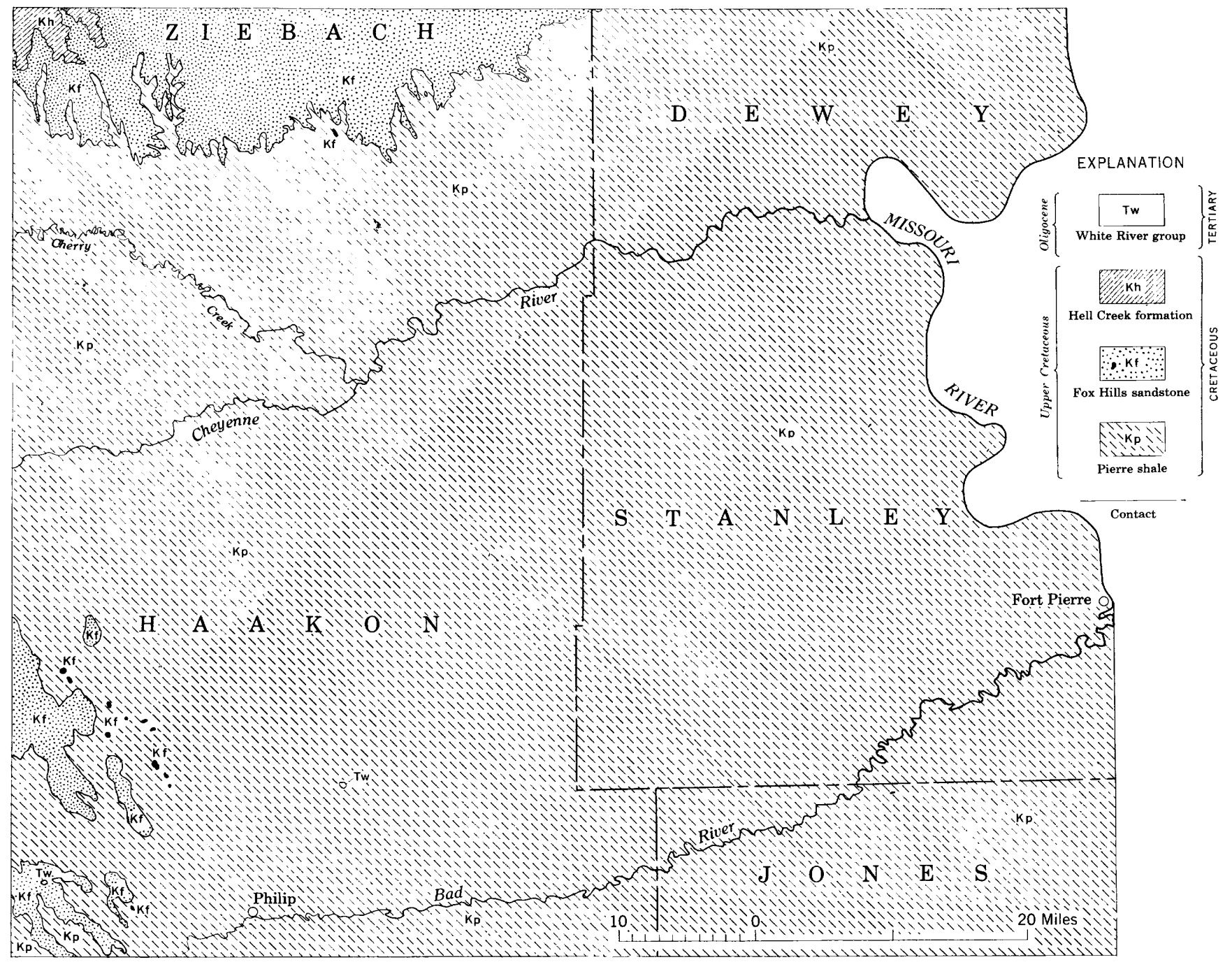

Figure 10.-Geologic map of central South Dakota west of the Missouri River. From Darton (1951). 
Although Searight (1937) lists these two ammonites as occurring in the Mobridge member, Dr. K. M. Waagé (oral communication) has suggested that D. conradii (Meek) probably is restricted to the Trail City member of the Fox Hills sandstone. Inasmuch as concretions of this type have not been recognized in the Mobridge and Elk Butte members in the Pierre area, and as the concretions typical of the Elk Butte of the Pierre area do not occur in the gray shale and claystone exposed in the road cut, it seems likely, although not certain, that the outcrop south of Fort Pierre is a fine-grained facies of the Fox Hills sandstone. If this inference is correct, there is little doubt that the Fox Hills sandstone once covered the Pierre area.

\section{ABSENCE OF DEPOSITS OF TERTIARY AGE}

The 1932 geologic map of South Dakota shows two outcrops of Miocene deposits near Pierre. One is on Medicine Knoll in the northeast part of the Canning quadrangle. The presence of rocks of Miocene age at this place was suggested by Todd $(1894$, p. 110) in the following statement:

Beds have been found in the Ree Hills which have furnished numerous species of fresh water fishes. . . These may belong to [a] later epoch of the Tertiary than the White river [formation], but it seems not improbable that the same formation occurs in Medicine Knoll, near Blunt. Various conspicuous buttes west of the Missouri to the north and east of the continuous Tertiary beds doubtless contain the same formation. . . .

Todd evidently considered this inference ample proof; his accompanying geologic map shows rocks of Miocene age on Medicine Knoll. Inasmuch as this geologic map also shows sediments of Miocene age on Willow Creek Butte in the Oahe quadrangle, it is inferred that this is the source of the same information which appears on the 1932 and 1951 (Darton, 1951) geological maps of the State.

In the course of mapping the Canning quadrangle in 1949 and 1950 a careful search was made on Medicine Knoll for bedrock other than Pierre shale. None was found. Such a deposit could lie below the cover of glacial drift, but this is considered unlikely. The altitude of Medicine Knoll is about 2,030 feet. Eight miles southeast of Medicine Knoll, the Mobridge member of the Pierre shale is exposed at an altitude of about 1,975 feet. By analogy, the Mobridge member should occur at least as high in Medicine Knoll unless removed by erosion in the Pleistocene. It is very probable that the glacial drift rests directly on Pierre shale.

Willow Creek Butte is capped by Pleistocene stream alluvium. It is not known whether this deposit was originally thought to be of Miocene age, or whether
Todd deduced, that becanse of the height and prominence of this butte, it should be capped by Miocene strata.

\section{DEPOSITS OF PLEISTOCENE AGE}

Deposits of Pleistocene age in the Pierre area are of two principal types: deposits chiefly of alluvial origin that range in age from Yarmouth to Wisconsin, and glacial deposits of Wisconsin age that include till, stratified drift, and loess. The nonglacial deposits are found southwest of the Missouri River only; the glacial drift is most widely distributed in and northeast of the Missouri River trench, although scattered glacial erratics and a few outwash deposits indicate that a glacier covered most of the area southwest of the Missouri River during the Wisconsin stage.

The Pleistocene sequence used in this report is as follows:

Wisconsin glacial stage
Mankato substage
Cary-Mankato interval
Cary substage
Tazewell-Cary interval
Tazewell substage
Iowan-Tazewell interval
Iowan substage
Sangamon interglacial stage
Illinoian glacial stage
Yarmouth interglacial stage
Kansan glacial stage
Aftonian interglacial stage
Nebraskan glacial stage

Tentative correlations of Pleistocene deposits in the Pierre area with the above subdivisions of the standard Pleistocene section have been made possible by Flint's (1955) investigation of the Pleistocene geology of easterm South Dakota.

\section{PRE-WISCONSIN DEPOSITS}

No glacial drift of any pre-Wisconsin stage has been identified in the Pierre area. If pre-Wisconsin glacial deposits were present once, it is very likely that they did not survive the dissection that followed initial cutting of the Missouri River trench.

The oldest known Pleistocene sediments of pre-Wisconsin age near Pierre are deposits of sand and pebblegravel ${ }^{3}$ that cap high knobs southwest of the Missouri River.

One of these deposits is several miles north of the Oahe quadrangle at Standing Buttes (fig. 20); it is included in this discussion because it is inferred to be the oldest Pleistocene deposit in the region.

\footnotetext{
3 Size terms of sediments follow Wentworth's (1922) classification throughout.
} 
NONGLACIAL DEPOSIT OF PRE-KANSAN AGE(?)

The highest and probably the oldest post-Cretaceous sediment near the Pierre area is a deposit of sand and gravel that caps Standing Buttes in secs. 1, 2, 3, 11, and 12 , T. 7 N., R. 27 E., about 7 miles north of the Oahe quadrangle. The top of the highest butte lies at an altitude of about 2,215 feet, is 8 miles west of and about 780 feet above the valley floor of the Missouri River. The lithology of this deposit indicates western provenance; the pebbles are of limestone and chalcedony that can be matched with formations of Cenozoic age in west-central South Dakota. Proportions of each rock type, determined by identification of 200 pebbles about 2 inches in diameter are summarized in the following table.

$\begin{array}{lr}\text { Rock type } & \text { Percent } \\ \text { Granite } & 3 \\ \text { Schist } & 1 \\ \text { Limestone } & 42 \\ \text { Sandstone and quartzite } & 16 \\ \text { Siltstone } & 1 \\ \text { Chert and chalcedony } & 35 \\ \text { Quartz } & 2\end{array}$

In the Standing Buttes deposit no pebbles were found of a distinctive green quartzite that occurs in the deposits at Willow Creek Butte and at the Stroup locality described below. The sediment consists predominantly of sand with lenses of pebbles and a few small cobbles.

The material contains bone fragments and teeth of mammals as well as fossil gastropods; the latter are very poorly preserved. The rertebrates identified include rabbit, horse, camel and proboscidean. Dr. C. W. Hibbard (written communication, November 15 , 1949) identified a fossil tooth as follows:

STN 1-2. Fragment of lower molar. Note V-shape of metaconid-metastylids. This condition occurs very rarely in Equus. If this tooth is of Hippotigris-("Plesippus") it is from an Upper Pliocene or Nebraskan deposit.

Hibbard subsequently (written communication January 2, 1951) revised his age assignment of STN 1-2. He stated that he had collected Hippotigris-("Plesippus") from "sands and gravels overlying Meade silts into which they were channeled." This indicates that the form existed at least until early Yarmouth time in Kansas.

The presence of the Hippotigris tooth may indicate that the sediments were formed in the late Pliocene or Nebraskan. However, because the tooth is abraded, it is possible that it was derived from a deposit that antedates the sediments at Standing Buttes.

The deposit at Standing Buttes is capped with the best-developed soil profile found in or near the Pierre area; furthermore, this profile was observed on a slope and thus probably does not represent the maximum thickness of the original soil. At the top of the soil profile that remains, there is 16 inches of noncalcareous silty clay, brownish black in the uppermost 6 inches, grading downward into a browner soil. A pH of 7 was recorded at a depth of 2 inches, 6.5 at 5 inches, 4 at 7 inches, 4.5 at 10 inches, and 7 at 12 inches. The noncalcareous silty clay is underlain by 15 inches of calcareous grayish-orange silty clay containing granules; this layer grades downward into sand and granule gravel. The sand and gravel, as well as most of the silty clay, is thoroughly impregnated with disseminated secondary calcium carbonate. This soil profile is leached to a greater depth and has a more acidic reaction in the leached zone than does a similar soil profile developed on a nearby sand and gravel deposit of probable Yarmouth age described below. It seems likely, therefore, that the Standing Buttes deposit is older than Yarmouth.

The presence of bones of terrestrial mammals indicates that the deposit at Standing Buttes was formed by a stream, and the lithology of the pebbles indicates that this stream must have come from the west, although no other alluvium at the same or higher altitude is known to occur within a distance of at least 10 miles west or southwest of Standing Buttes.

\section{NONGLACIAL DEPOSITS OF PROBABLE YARMOUTH AND ILLINOIAN AGE}

Widely scattered small deposits of sand and gravel in the southern half of the Oahe quadrangle are remnants of a once-continuous band of stream alluvinum laid down by the Bad River. The alluvial deposits range in thickness from a few feet to 25 feet; generally they are less than 10 feet thick. That this alluvium once extended into the Pierre quadrangle is indicated by scatterings of nonglacial pebbles on the crests of hills in the NW1/4 sec. 22 and the SE1/4 sec. 28, T. $5 \mathrm{~N}$., R. 30 E., and on the crest of Brown Hill.

One of the highest of these alluvial deposits in the Oahe quadrangle is located on the crest of Willow Creek Butte where it overlies the Elk Butte member of the Pierre shale. The top of Willow Creek Butte lies at an altitude of about 2,090 feet, or about 650 feet above the Missouri River flood plain, 5 miles north of the butte. The deposit capping the butte consists predominantly of sand and granule gravel with a minor amount of pebble gravel. The gravel is predominantly limestone, loosely consolidated sandstone, and pieces of chalcedony, indicating western provenance. One green quartzite pebble was noted in this sample of gravel. No fossils suitable for identification were found. The following table indicates the relative proportions of 
the rock types, based on the identification of 200 pebbles picked at random.

$\begin{array}{lr}\text { Rock type } & \text { Percent } \\ \text { Granite } & 2 \\ \text { Gabbro and basalt } & 1 \\ \text { Shale } & 1 \\ \text { Limestone } & 12 \\ \text { Sandstone and quartzite } & 6 \\ \text { Siltstone - } & 2 \\ \text { Chert and chalcedony } & 75 \\ \text { Quartz }\end{array}$

South and east of Willow Creek Butte, in the NW1/4 sec. 26 and in the center of sec. 22 , T. 5 N., R. 29 E., are extensive bodies of sand and gravel at an altitude of about 2,000 feet. The largest, in sec. 26, will be referred to informally as the Stroup deposit. It resembles the deposit at Willow Creek Butte. Sand sizes predominate, but small cobbles are common and there are a few large cobbles. Most of the large cobbles are igneous rocks of probable glacial derivation and carbonate rocks of western provenance. The sediment is poorly stratified, with local cut-and-fill stratification. The composition of the sand and gravel, indicated by identification of 200 pebbles, is tabulated below.

\begin{tabular}{|c|c|}
\hline Rock type & Percent \\
\hline Granite & $\quad 0.5$ \\
\hline Limestone & 59 \\
\hline Concretions from Pierre shale & 8 \\
\hline Sandstone and quartzite & 8 \\
\hline Siltstone - & 0.5 \\
\hline Chert and chalcedony & 22 \\
\hline Quartz & 2 \\
\hline
\end{tabular}

Several pieces of green quartzite, ranging in size from pebbles to cobbles, occur in the deposit. The lack of rounding and the large size of some quartzite fragments suggest that they were not transported far from their outcrop. The quartzite is lithologically similar to a quartzite that caps Medicine Butte, 65 miles to the southeast in Lyman County. The quartzite at Medicine Butte has been correlated by Flint (1955) with sedimentary rocks in southwestern South Dakota and northern Nebraska that are generally regarded as being of upper Miocene and Pliocene age. Lithologically similar green quartzite of Miocene (?) age crops out in buttes in northwestern Sonth Dakota (Winchester Hares, Lloyd, and Parks, 1916, p. 34). The presence of this rock in the deposits at Willow Creek Butte and the Stroup locality almost certainly indicates that the quartzite cropped out not far west of the Pierre area when these deposits were formed. The absence of this rock in the alluvinm at Standing Buttes might indicate that outcrops of the quartzite had not yet been uncovered by erosion at the time of deposition of that sediment.
The igneous cobbles probably were originally dropped on the surface of the deposit by a glacier during the Wisconsin stage, and became mixed with the alluvium during excavation.

Many bone fragments and teeth have been found in the Stroup deposit; they include mammoth, camel, horse, and badger. A mammoth tooth in an excellent state of preservation and a 6 -foot length of tusk suggest that these fossils are essentially in place. In addition, abrasion of several of the horse teeth is minor, indicating that these fossils were not transported far by a stream. Some of the specimens were identified by Dr. Hibbard (written communication, January 2, 1951) as follows:

OA61-6, 12, 15, 30, 38, 50, and 51: These specimens are Equus and compare well with what I call Equus niobrarensis. The range of this type of tooth has been found in the High Plains from just below the base of the Pearlette ash to the top of the Kingsdown.

This opinion indicates that the horse teeth collected at the Stroup locality have been found elsewhere in deposits ranging in age from early Yarmouth to Wisconsin.

Dr. Schultz (written communication, March 14, 1951) identified these and other specimens from the same locality as teeth and bones of Equus excelsus, ref., and stated that they "appear to have come from postKansan deposits (Sappa [late Kansan or early Yarmouth] or later), possibly as late as Illinoian."

Dr. Schultz and Dr. Hibbard are thus in agreement that the bones and teeth from the Stroup deposit are from post-Kansan mammals. However, the stratigraphic dating of the horses is based on occurrences in sediments that overlie Kansan till, which is itself unfossiliferous. It is conceivable, therefore, that this deposit could be as old as late Kansan.

The Stroup deposit is overlain by a well-developed soil profile (fig. 11) consisting of a horizon of humified and leached sand about 14 inches thick that overlies a calcareous sandy silt about 12 inches thick. The sandy silt and the underlying sand and gravel are heavily impregnated with secondary calcium carbonate. The $\mathrm{pH}$ of the humified and leached sand is 6.5 to 7.5 ; that of the underlying horizons is very alkaline owing to the abundance of calcium carbonate.

The deposit at the Stroup locality is but one of a number of similar bodies of sand and gravel north of the Bad River at altitudes of 1,890 to 2,105 feet. These deposits are remmants of a northeastward-trending band of flood-plain alluvium, deposited when the ancestral Bad River was flowing on surfaces 300 to 600 feet higher than the present valley floor. Although the deposits all have the same general range in grain size 


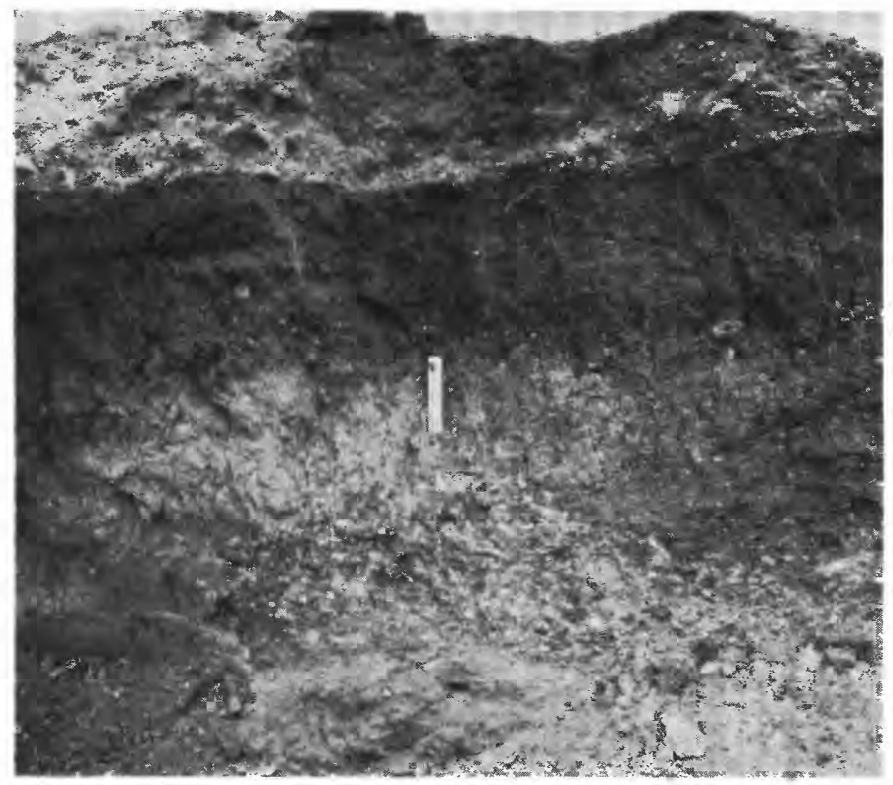

FigUre 11.- Soil profile on alluvium of probable Yarmouth age at the Stroup gravel pit. Top of ruler is at the base of the leached horizon; the ruler is about 6 inches long. Light-colored material above the leached horizon is spoil.

and lithology, they are roughly grouped according to their range in altitude (fig. 12). The highest group, at an altitude of about 2,100 feet, is represented by the deposit at Willow Creek Butte. The next lower group ranges from 2,050 feet at the west edge of the Oahe quadrangle to 1,965 feet at the east edge of the Oahe quadrangle and is represented by the deposit at the Stroup locality. The lowest group, which ranges from 1,960 feet in the west to 1,890 feet at the east edge of the quadrangle, is represented by deposits in sec. 16, T. 4 N., R. $29 \mathrm{E}$. The difference in altitude of these three groups does not necessarily have any special historical significance; each group of essentially the same altitude probably represents a period of lateral corrasion while the ancestral Bad River was at grade during an episode of general downcutting. This episode of downcutting with intermittent lateral corrasian and deposition is inferred to have started before early Yarmouth time and to have lasted until early Illinoian time. Because no significant differences have been recognized in the alluvial deposits of this episode, they all have been assigned a probable age of Yarmouth and Illinoian. The Yarmouth date is inferred from the probable age of the fauna included in the deposit at the Stroup locality; the limiting date of Illinoian time for the youngest deposits is inferred from evidence that the Missouri River trench originated during the maximum of the Illinoian glacial stage; the high-level alluvium antedates the initial cutting of the trench.

\section{ABSENCE OF DEPOSITS OF SANGAMON AGE}

Deposits of the Sangamon stage have not been recognized in the Pierre area. This might be expected because the stage was characterized chiefly by stream erosion and mass wasting, quickened by the lower base level created by the cutting of the Missouri River trench during the Illinoian stage.

\section{DEPOSITS OF WISCONSIN AGE}

The extensive and locally thick deposits of glacial drift in the Pierre area are all believed to be of Wisconsin age. The correlation of these deposits with the several Wisconsin substages, however, is still tentative. A limiting date for the oldest deposits is provided by vertebrate fossils of post-Kansan age in high-level stream alluvium in the Oahe quadrangle. This alluvium is older than the Missouri River trench. The trench evidently was formed marginal to the glacier of the Illinoian stage at its maximum westward extent. The limiting date for the youngest glacial deposits in the area is provided by Flint (1955) who mapped the drift border of the Mankato substage about 15 miles northeast of the Canning quadrangle. Presumably, therefore, deposits recording ice advances west of the Mankato drift border are of pre-Mankato age. A subdivision of these deposits into the Iowan, Tazewell, and Cary substages is based on superposition of drift sheets, morphologic differences of moraines, topographic position and grain size of outwash deposits, and buried soil profiles in loess deposits.

\section{TILL OF THE WISCONSIN STAGE}

The till sheets of the several Wisconsin substages could not be differentiated for mapping purposes because of generally similar lithologic characteristics and a thick cover of colluvium that masks contacts. All the till in the area is therefore mapped as till of the Wisconsin stage and is differentiated only on the basis of topography. Where the till surface is undulatory, denoting constructional topography, the till is mapped as moraine, which is defined as an accumulation of glacial drift built directly by glacier ice and characterized by constructional topography independent of control by the underlying surface. Moraine that has a ridgelike form and has been deposited at a glacier terminus is slıown as end moraine; drift characterized by constructional topography of small local relief that lacks any apparent linear element is shown as ground moraine. Areas that are underlain by till but in which erosional topography has replaced constructional topography are shown on the accompanying geologic maps as undifferentiated drift. Along the north wall of the 


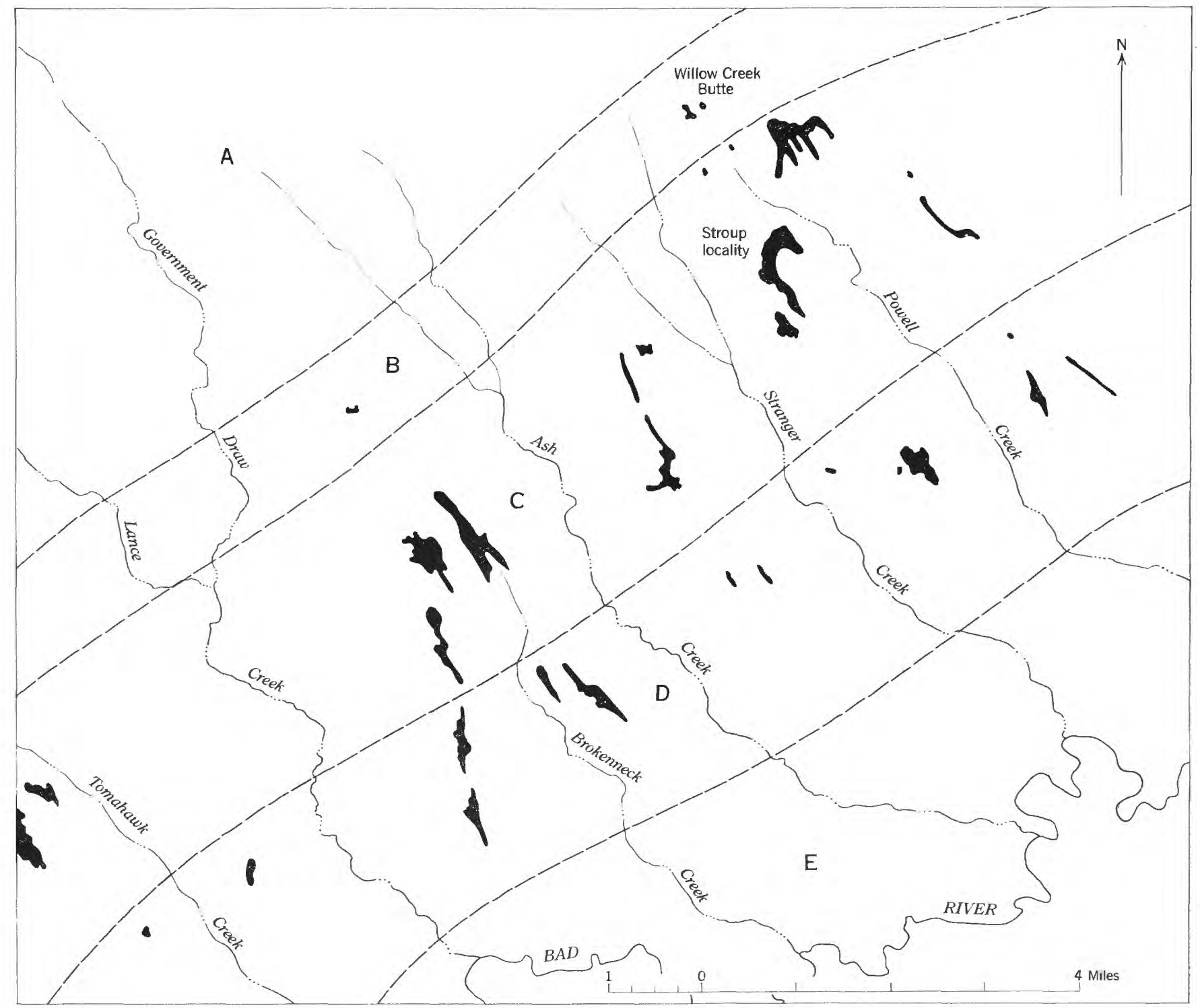

FIGdRE 12. - Map showing alluvial deposits of probable Yarmouth and Illinoian age in the sonth half of Oahe quadrangle. Long dashed lines indicate the inferred northern edge of successive flood plains of the ancestral Bad River. Letters designate successive flood plains and contemporary valley walls. $A$, northern valley wall of ancestral Bad River; $B$, highest and oldest known position of ancestral Bad River flowing at altitude of about 2,100 feet; $C$, position of ancestral Bad River at altitude of 2,050 (to the southwest) to 1,965 feet (to the northeast); $D$, position of ancestral Bad River at altitude of 1,960 feet (to the southwest) to 1,890 feet (to the northeast); $E$, south valley wall of ancestral Bad River. The Bad River probably cut southward and downward even farther before the advance of the Illinoian glacier.

Missouri River trench north of Peoria Bottom and east of Rousseau and along the walls of the Medicine Creek valley downstream from Canning the map unit designated as undifferentiated drift includes deposits of stratified drift, intercalated with and between till sheets. On the uplands northeast of the Missouri River, till forms a very high proportion of the total area and ice-contact and proglacial stratified drift deposits are areally insignificant.

End moraines in the Pierre and Canning quadrangles merge laterally with ground moraine in such a way that there is no sharp contact between the two forms.
Rather, there is a zone of contact that ranges in width from several hundred yards to perhaps half a mile. Therefore the limits of the patterns shown on the accompanying geologic maps as indicating the two types of moraine are only approximate.

The distinctness of the contact between end and ground moraine is, at least in part, a function of time. Initially a ridge of debris deposited at a glacier terminus has steeper slopes and greater local relief than adjacent areas over which the ice melted back relatively rapidly. All other factors being equal, initial size of the end moraine is a function of the length of time the 
glacier margin stood along any particular line (Flint, 1955). With the passage of time, initial slopes on the end moraine are modified by mass-wasting processes and stream erosion; the products of these processes accumulate and help to obscure the original margins of the moraine. Loess likewise obscures the ground and end moraine margins in that it smooths out preexisting topographic irregularities by filling in depressions. Some of the loess deposited on the end moraine is reworked by mass wasting and by streams and is redeposited at the margin of the moraine. Thus over a period of time there is a tendency for an end moraine to decrease in altitude and to broaden. After the disappearance of constructional topography from the end moraine, probably the moraine still would exist for some time as a recognizable topographic feature. One end moraine in the Pierre area approaches this condition; it is nearly devoid of the constructional topography characteristic of younger end moraines of Wisconsin age in central and eastern South Dakota, but the linear trend of the broad swell suggests its origin.

\section{DEPOSITS OF THE IOWAN SUBSTAGE}

Much of the glacial drift of the Iowan substage, and thereby the morphologic features of that drift, has been covered with deposits of subsequent glaciers.

There is no incontrovertible evidence in the Pierre area to prove the existence of more than one pre-Cary glaciation in the Wisconsin. Therefore it must be acknowledged that either the glacier of the Iowan or the Tazewell substage, or both, might be responsible for the pre-Cary glacial features of the area. The known evidence, however, strongly supports, although it does not prove, a two-fold glaciation in early Wisconsin time; it is therefore tentatively inferred that the area was glaciated both during the Iowan and the Tazewell substages. In two localities only is there stratigraphic evidence that each substage is represented by lithologically distinctive deposits, and even at these places the presence of two tills in superposition is not absolute proof that the tills are not possibly of the same age.

TILL

Exposures of glacial drift of the Iowan substage overlain by till of Tazewell age occur at only a few localities in the Pierre area. One is in a large opencut made by the Corps of Engineers in 1946 in the NW1/4 sec. 6, T. 111 N., R. 79 W., in the east wall of the Missouri River trench. This excavation was made to determine the geologic relations of the east abutment area of the Oahe Dam; the excavation will be referred to here informally as the test pit exposure.

The stratigraphic section of the test pit exposure follows:

7. Loess, dusky-yellow (5Y6/4, when dry) _-__-_-

6. Loess, humified, olive-gray $(5 Y 4 / 1)$ to medium dark-gray $(N 4$, when dry) -.............

5. Loess, mottled, dusky-yellow (5Y6/4) and light-olive-gray (5Y6/1, when moist) _.....-

4. Till, clay-rich, calcareous, contains boulders of unweathered igneous and metamorphic rocks as much as 6 feet in diameter. Moderate yellowish brown $(10 Y R 5 / 4)$ to moderate brown ( $5 Y R 4 / 4$, when dry) -.-.-

3. Sand, very fine to medium-grained, silt and clay, locally laminated, locally contains coarse and very coarse sand, moderate yellowish-brown (10YR5/4, when moist) --

Ft. In.

3

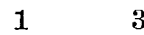

5

35

1. Pierre shale (exposed in 1946 but covered with colluvium and alluvium in 1948). Altitude of contact of shale and drift, about 1,600 feet.

Tentative age interpretation :

7. Cary and post-Cary. ${ }^{4}$

6. Tazewell-Cary interval soil developed on Tazewell loess.

5. Tazewell.

4. Tazewell.

3. Iowan-Tazewell interval alluvial deposit.

2. Iowan.

The till that forms unit 2 of the stratigraphic section contains more sand and pebble-sized material and less clay than does most of the till in the Pierre area. Boulders in this matrix of sand and pebbles include spheroidal masses of Pierre shale and unoxidized clayrich till as much as 3 feet in diameter, and boulders of igneous, metamorphic, and well-consolidated sedimentary rocks. The till contains masses of medium to coarse sand and pebble gravel. A persistent layer of sand as much as 6 feet thick lies about 50 feet below the top of the till. This layer pinches and swells and appears to have been deformed after deposition.

There is no other outcrop of coarse till similar to that in the test pit exposure except for small exposures in secs. 26 and 27, T. 112 N., R. 80 W., at the east end of Peoria Bottom. In the summer of 1951, however, excavations exposed bodies of similar material in the Iowan ice-contact stratified drift just west of the Oahe Dam in secs. 30 and 31. This locality is on the west trench wall directly opposite the test pit exposure. The lack of an appreciable amount of material of silt and clay size in the till very likely is the result of removal of fine sediment by running water during deposition; the presence of large inclusions of crossbedded sand in the till seems to support this inference. The included large

${ }^{4}$ For terminology of age of loess deposits see page 39 . 
boulders of Pierre shale also are unique in the Pierre area. In many till exposures fragments or pebbles of shale have been observed, but nowhere as abundant or as large as in the test pit exposure. The shale boulders are rounded to subrounded, suggesting that the individual shale blocks were shaped by abrasion rather than by rupture. It is inferred from this that blocks of shale, saturated with water and frozen, were plucked from the bedrock surface over which the ice sheet passed. If the strength of the shale had not been greatly increased by ice in joints and along bedding planes, failure by rupture and flowage would likely have taken place during glacial transport.

The possibility that the lowermost till in the test pit exposure is pre-Wisconsin has been considered; however, the base of the till (at about 1,600 feet altitude) lies below the altitude $(1,700-1,750)$ of what is inferred to be the pre-Sangamon surface of the area, thus presumably the till is no older than Iowan. Furthermore, if the till were pre-Wisconsin, probably there would be lithologic evidence of a period of weathering representing an interglacial stage or stages. This ovidence would be in the form of a zone of weathered drift at the top of the lower till. The boulders near the top of the unit, however, are fully as fresh and unaltered as those near the base of the unit. It is true that oxidation has occurred throughout most of the lower till, but its permeable character is favorable to rapid oxidation. The possibility remains, however, that a weathered zone at the top of the till once was present but subsequently was removed by erosion.

The test pit exposure lies about 17 miles west of the Cary drift border in the eastern part of the Canning quadrangle. It is therefore tentatively concluded that the till deposits are of pre-Cary age, the lower of Iowan age and the upper of Tazewell age.

A second locality at which two till deposits of Wisconsin age are superposed is in a deep gully in the SW1/4 sec. 35 , T. 111 N., R. 79 W., southeast of the Pierre Municipal Airport. The drift section at this exposure is described below.

6. Loess, moderate-yellowish-brown $(10 \Gamma R 5 / 4)$; lower $4 \mathrm{ft}$ mottled moderate yellowish brown and light olive gray when moist.

5. Sand, medium-grained, and silt-_ Till, moderate-brown (5YR3/4) to dark-yellowishorange $(10 Y R 6 / 6)$ when dry, pebbly, clay-rich, oxidized, calcareous; grayish-brown (5YR3/2) material stains joint surfaces of lower $4 \mathrm{ft}$; joints in lower $4 \mathrm{ft}$. filled with gypsum; contains unweathered boulders of igneous rock as much as $4 \mathrm{ft}$ in diameter, small chips and flakes of Pierre shale and many iron-oxide concretions from Pierre shale 23
3. Sand, coarse to very fine; alternately crossbedded and horizontally stratified in lower $6 \mathrm{ft}$, horizontally bedded in upper $20 \mathrm{ft}$; contains lenses of till and upward projections of the till unit below and normal faults with as much as $2 \mathrm{ft}$ vertical displacement

2. Till, clay-rich, compact, calcareous, unoxidized except along joints, which are coated with a very dusky red $(10 R 2 / 2)$ stain; contains unweathered boulders of igneous rock as much as $3 \mathrm{ft}$ in diameter. Unoxidized color of till is gray (N6) when dry; oxidized color, moderate-yellowishbrown (10YR5) when dry -.-..--

1. Pierre shale, Verendrye member. Altitude of contact of shale and drift about $1,645 \mathrm{ft}$

Age interpretation :

6. Tazewell and post-Tazewell

5. Tazewell stratified drift

4. Tazewell till

3. Iowan ice-contact stratified drift

2. Iowan till

At this locality, the section exposed resembles the test pit exposure in sequence of drift units, although the appearance of the lowermost till in the two sections is notably different. In the exposure at the airport there is nothing in the lower till itself suggestive of a pre-Wisconsin age. Included pebbles of granitic rocks are fresh even at the top of the till, and oxidation evidently is the only weathering process that has occurred in the till. The joints in the lowermost till are more prominent and have heavier coatings of oxides than have the joints in the overlying till. The thick unit of sand contains no evidence of a weathering period before deposition of the overlying till. This sand unit was deposited nearly contemporaneously with the lower till; the projections of till into the sand, and lenses of till in sand clearly demonstrate its origin as an icecontact deposit (fig. 13). The uppermost till overlies the sand with a sharp contact and the sand shows no evidence of deformation by the overriding ice. Because in this drift section there is nothing suggestive of preWisconsin age, the entire section is referred to the Wisconsin glacial stage. Inasmuch as this exposure lies more than 15 miles west of the Cary drift border, the two till deposits are tentatively refered to the Iowan and the Tazewell substages.

No direct evidence has been found to indicate that the two till deposits in each of the exposures described above are of different age. In each case, the lithologic characteristics of the upper and lower tills are different, but conceivably each upper till could be referred to a late phase of the same substage as that during which the lower till was deposited.

The most extensive outcrop of till inferred to be of

6

(2)

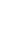

(1)




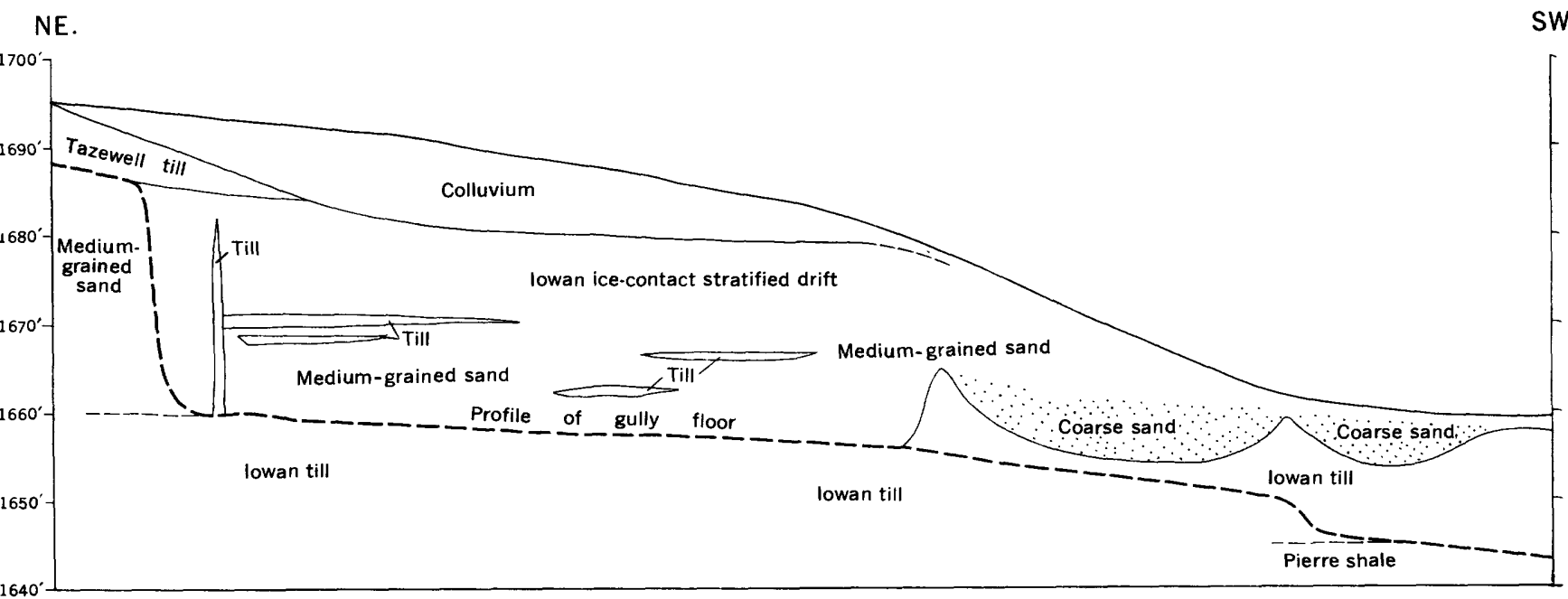

20 60 Feet

Figure 13.-Exposure in southeast wall of gully in SW1/4 sec. 35, T. $111 \mathrm{~N}$. ., R. $79 \mathrm{~W}$., southeast of the Pierre Municipal Airport. The mediumgrained sand is mostly horizontally laminated; beds ranging from 2 to 4 inches thick bearing foreset laminae occur near base of unit. The coarse sand is foreset bedded and lies in depressions in the underlying till. High-angle faults with displacements of a few inches to several feet cut the stratified drift. Northeast of this section, Tazewell till is overlain by more than 10 feet of medium-grained sand and loess.

79 W., northeast of Pierre. Tazewell ice evidently was prevented from reaching this area by Snake Butte on the north and by a northward trending ridge parallel to Hilgers Gulch on the east.

Exploratory drilling north of Snake Butte by the Corps of Engineers has revealed an extensive area underlain by glacial drift that locally is more than 200 feet thick. This may suggest that deposits of more than one glacial substage are represented. No till of preWisconsin age is believed to occur in these thick drift sections because the base of the drift lies below the altitude of what is inferred to be the pre-Sangamon surface of the area.

\section{STRATIFIED DRIFT IN THE MISSOURI RIVER TRENCH}

Deposits of stratified drift of Iowan age occur principally as a proglacial ${ }^{5}$ valley train, ${ }^{6}$ although in one area, an ice-contact origin of the drift is indicated. There is no certain stratigraphic evidence that any one outwash deposit within the Missouri River trench is of Iowan rather than of Tazewell age; stratified drift deposits known to be related to the two substages have not been seen in direct contact. However, there appear to have been two distinct times at which there was aggradation of coarse-grained outwash within the Missouri River trench; the two periods of aggradation were separated by an interval of downcutting. The higher

\footnotetext{
5 The term "proglacial" refers to glacial drift deposited beyond the limits of the glacier as opposed to ice-contact stratified drift which has been deposited in immediate contact with the glacier.

$A$ valley train is defined as a long narrow body of outwash confined within a valley (Flint, 1947 , p. 135).
}

of these two outwash deposits is assigned to the Iowan substage and the lower to the Tazewell substage.

A topographically high, extensively dissected deposit of stratified drift of probable Iowan age occurs southwest of the Missouri River at the bend 7 miles upstream from Pierre. The upper surface of this deposit extends to a little more than 1,800 feet and its base ranges in altitude from 1,650 feet to 1,700 feet. In the summer of 1950 this deposit was partly excavated during the construction of the Oahe Dam. The material ranges widely in grain size both vertically and laterally, and several large blocks of clay-rich till completely enclosed by sand and gravel were noted. These characteristics suggest that the deposit originated at a time when the Missouri River trench at that place was partly filled with ice.

A deposit similar to the one described above occurs north of the Missouri River in sec. 27, T. 112 N., R. 80 W. This deposit has been dissected to about the same extent and its upper surface lies at about the same altitude as the glacial sand and gravel southwest of the Missouri River.

In the Missouri River trench downstream from these ice-contact stratified-drift deposits, outwash sand and gravel of the Iowan substage appears to have originated as a valley train. Remnants of this train are widely scattered and extensively dissected. One is in the western part of the Canning quadrangle on the north valley wall of the Missouri River. Although this deposit is stratigraphically beneath the till of Tazewell age that crops out immediately to the north, this fact alone does not prove the Iowan age of the stratified drift. The 
stratified drift in this deposit is very coarse, with many cobbles and boulders in a matrix of pebble gravel. The thickness of the sand and gravel is 15 to 20 feet. Similar sand and gravel deposits a little less than 2 miles east of the town of Pierre, in the SE $1 / 4 \mathrm{NE} 1 / 4$ sec. $2, \mathrm{~T}$. 110 N., R. 78 W., likewise are overlain by till of Tazewell age. At this locality, however, the gravel, in turn, overlies till. The two till deposits may each be of the same age in that they represent successive advances of the Tazewell ice margin, but probably the stratified drift and underlying till are of Iowan age.

Two additional remnants of the valley train of the Iowan substage are in the southeast corner of the Canning quadrangle. One, on the north side of the Missouri River between Berry Draw and Carlson Draw, extends up to an altitude of about 1,690 feet and is stratigraphically beneath till of Tazewell age. On the opposite side of the Missouri River, south of Stony Point, an extensive stratified drift remnant underlies a terrace at about the same altitude. This deposit is very coarse grained and many large boulders have been concentrated on and below the terrace face by removal of the fine-grained components of the sand and gravel.

The sand-and-gravel deposits in the Missouri River trench assigned to the Iowan substage have several features in common: the average grain size is generally coarse, and large numbers of cobbles and boulders are included; the upper surfaces of the deposits are limited to altitudes ranging from 1,800 feet north of Pierre to about 1,700 feet downstream in the southeastern part of the Canning quadrangle; dissection of the deposits has been extensive.

A deposit of stratified drift lies adjacent to Hilgers Gulch, a valley that joins the Missouri River trench at Pierre. This deposit ends southward abruptly at the Missouri River trench, but the valley occupied by the deposit extends northward to a gap cut into the eastern end of Snake Butte. Because surficial drift north of Snake Butte is ground moraine of Tazewell age it would seem most likely that the gap through Snake Butte was last used by melt water during the Tazewell substage. However, outwash deposits of only one age have been recognized in Hilgers Gulch; the surface of these deposits lies at an altitude of about 1,700 feet where it is truncated by the Missouri River trench. If the deposits are of Tazewell age, it is difficult to reconstruct the base level in the Missouri River trench to which the deposits could have been graded; the profile of the Missouri River shortly after the maximum of the Tazewell substage was more than 100 feet lower than the surface of the stratified drift in Hilgers Gulch. It is therefore inferred that the stratified drift in Hilgers Gulch is of Iowan age, and that it was graded to the high-level outwash valley train of Iowan age in the Missouri River trench.

The following sequence in the stratified drift deposits in Hilgers Gulch is exposed in a cutbank in the center of sec. $27, \mathrm{~T} 111 \mathrm{~N} ., \mathrm{R} .79 \mathrm{~W}$.

5. Covered to top of terrace. Feet

4. Sand, medium- and coarse-grained 16

Sand, medium- and coarse-grained, and pebble gravel and clay, interbedded; lenses of clay-rich till as much as 8 in thick.

2. Gravel; grain size ranges from pebbles to boulders as much as $2 \mathrm{ft}$ in diameter ; very poorly sorted___- 10

1. Pierre shale

The decreasing grain size upward in this deposit might have been caused by diminishing discharge of melt water through the gap in Snake Butte.

An ontwash deposit of possible Iowan age is exposed in the west valley wall of Medicine Creek in the NE1/4 sec. 3, T. 110 N., R. 77 W. This deposit consists of three units of differing grain size: a lower unit, 45 feet thick, consisting of pebble to boulder gravel which rests on Pierre shale; a middle unit, 55 feet thick, consisting mostly of silt and sand; and an upper unit, 25 feet thick, consisting of pebble and cobble gravel. The uppermost unit is overlain by Tazewell till. Although the correlation is by no means certain, it is suggested that the lower two units are of Iowan age, and the upper unit represents Tazewell advance outwash.

PROGLACIAI OUTWASH DEPOSITS IN VALLEYS TRIBUTARY TO THE BAD RIVER

Small remnants of outwash sand and gravel occur high on the sides of the valleys of Willow Creek and Dry Run, tributaries of the Bad River. These deposits range in altitude from 1,720 to 1,800 feet. The most extensive deposit of this nature occurs near the center of sec. 14, T. 5 N., R. 30 E. At this locality, the deposit is from 5 to 20 feet thick, and the stratification indicates that the sediment was deposited by a stream flowing in a southerly direction. Although the material is predominantly sand and pebble gravel, it includes granitic boulders as large as 14 inches in diameter. The lithology of 200 pebbles selected at random is given below.

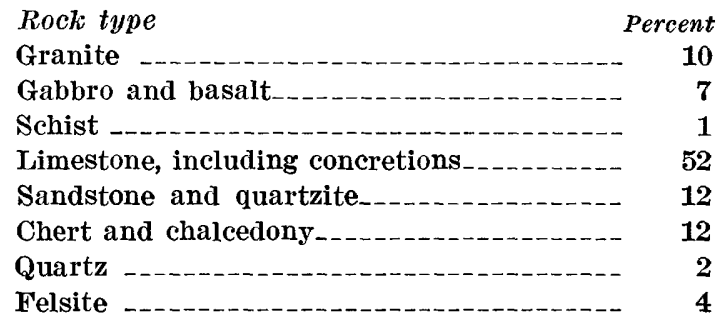

The presence of this proportion of igneous rocks indicates that the deposit was formed by glacial melt 
waters. The thinness of the deposits indicates that in most places they represent veneers of alluvium and outwash left on shale straths cut by melt water rather than aggradational valley fill deposits.

The gradient of the upper surfaces of the outwash deposits in the valley of Willow Creek, if extended southeastward, meets the Bad River trench at an altitude of 1,720 to 1,750 feet. Opposite the mouth of Willow Creek the extrapolated upper surface of the alluvial fill in the Bad River trench lies at an altitude of 1,720 to 1,730 feet; therefore the outwash deposits in the valleys of Dry Run and Willow Creek evidently were graded to the alluvial fill in the Bad River trench. If this inference is correct the outwash deposits are of Iowan age.

ALLUVIAL FILL IN THE BAD RIVER TRENCH

The most extensive fill of Wisconsin age in the $\mathrm{Bad}$ River trench is preserved as dissected and isolated deposits of sand and gravel, whose upper surfaces range from an altitude of nearly 1,800 feet in sec. 6, T. 3 N., R. 29 E. in the Oahe quadrangle, to 1,710 feet, 1 mile southwest of Fort Pierre. The lithology of this valley fill at one locality, based on the identification of 200 pebbles, is given below. The proportions of rock types represented in the pre-Wisconsin alluvium at the Stroup locality is included for comparative purposes.
Rock type

Granite -

Gabbro and basalt

Sandstone and quartzite

Siltstone

Chert and chalcedony Quartz

$N W$

Limestone, including concretions.

gins: western, represented by chert, chalcedony, and possibly quartz; and glacial, represented by the pebbles of igneous rocks. At most places where remmants of this fill are preserved, they extend a short distance up tributary valleys. In addition, the sand and gravel deposits rest on sloping bedrock surfaces rather than on essentially flat stream-cut straths. Accordingly, this deposit appears to be a valley fill rather than a mere veneer of alluvium left on a bedrock strath. The extrapolated surface of this fill from the south center of the Oahe quadrangle to 1 mile southwest of Fort Pierre has a gradient of about 5.5 feet per mile. A representative remnant of the fill lies in the $\mathrm{NE}_{1} / 4$ sec. 9 , T. 4 N., R. 31 E. At this place, approximately 20 feet of sand and pebble gravel are overlain by a deposit of coarse- and medium-grained sand. This sequence is taken to indicate that the competence of the stream that deposited the sediment was progressively decreasing owing, perhaps, to aggradation in the Missouri River trench. If the trench of the Bad River was filled to an altitude of about 1,710 feet near Fort Pierre, there must have been a corresponding fill in the Missouri River trench at about the same altitude. Stratified drift remnants in the Missouri trench at this altitude are inferred to be of Iowan age; consequently the alluvial, and in part glacial, fill in the Bad River trench at altitudes of 1,700 to 1,800 feet probably is also of Iowan age.

\section{SOUTHWESTERNMIOST EXTENT OF GLACIAL DEPOSITS}

At several localities thin and patchy till of unknown age occurs southwest of the Missouri River. The presence of outwash sand and gravel in the Bad River tributary valleys of Dry Run and Willow Creek and glacial erratics on uplands southwest of the Missouri River further establishes the fact that at least one glacier crossed the Missouri River trench and extended for some distance beyond it.

Glacial erratics occur both as isolated boulders and in groups of several dozen to several hundred southwest of the Missouri River in an area extending about 20 miles west of Pierre and approximately to the southeru boundary of Stanley County directly south of Pierre. Many of these boulders occur on broad, nearly flat upland surfaces.

The two most plausible modes of deposition of the boulders on the uplands are rafting by icebergs floating on a lake, and direct deposition by a glacier. If it is assumed that the erratics were rafted to their present positions on a vast, ice-dammed lake, some serious inconsistencies appear in their vertical and areal distribution. West of Pierre, boulders are found at alti-
The lithology of the deposit of Iowan age in the Bad River trench indicates that it is primarily of two ori- 
tudes of more than 2,000 feet, thus making necessary a lake level at least that high. Yet boulders are not found at much lower altitudes up the valley of the Bad River which must have been entirely inundated by the hypothetical lake. South of the Pierre area boulders are not found south of an eastward-trending line that seemingly has no relation to the topography; a topographic rise high enough to have held in a lake level at 2,000 feet lies more than 5 miles beyond the southernmost boulders. Further, in order to provide a source for the deposits of outwash sand and gravel of inferred Iowan age in the southeastward-trending tributary valleys of the Bad River, it seems necessary to assume that an ice sheet once covered most of the Pierre area.

It is inferred that a glacier extended at least as far southwest as a line connecting the westernmost and southernmost glacial erratics. If this line is altered to be consistent with existing topography, the outer margin of the ice sheet can be reconstructed.

Ice sheets tend to conform to the topography over which they flow; a glacier therefore generally extends farther along the axis of a valley than along an ad- jacent high ridge. This feature would be particularly true of the marginal area of an ice sheet; thus lobes of a drift border should coincide with broad depressions and reentrants should occur at high areas. The outermost margin of the glacier that crossed the Missouri River, reconstructed according to these principles, is shown in figure 14.

North of Willow Creek in the Oahe quadrangle the upland surface slopes steadily upward toward the north, so that the elevation of the west wall of the Missouri River trench increases from 350 feet, above the flood plain at the west end of Giddings Flat, to 600 feet just southwest of Chantier Creek. This scarp, although possibly not then as precipitous as now, must have been a formidable obstacle to the glacier that deposited the erratics southwest of the Missouri River. The restriction of glacial boulders to a narrow zone west of the trench in this area (fig. 14) therefore is expectable. The line that represents the southwestern limit of glaciation trends southwest from Willow Creek to a point about 20 miles west of Pierre, and then turns southeastward toward the Bad River. This broad are in the inferred ice margin represents

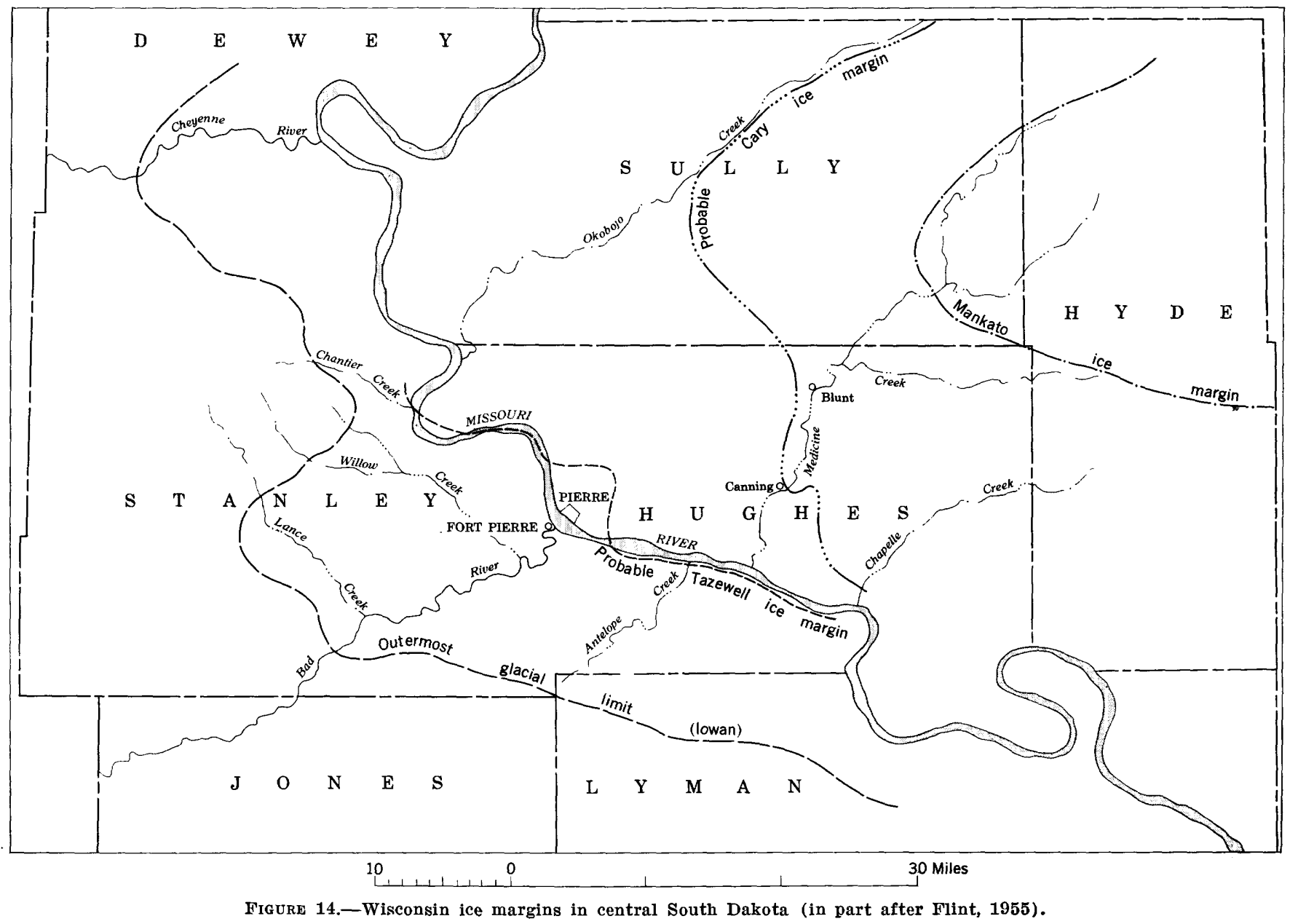


a glacial lobe that crossed the Missouri River trench between Peoria Bottom and the Bad River. Ideally it would seem likely that there should have been a westward projection of the ice margin coincident with the valley of the Bad River. However, the westward lobe of the inferred ice margin is coincident with the upland area between the Bad River and the eastwardtrending segment of Willow Creek, whereas the valley of the Bad River evidently exerted no appreciable effect on the ice. In possible explanation of this apparent anomaly, the grain of the topography north of the Bad River trends southeasterly; this area consists of high, broad ridges alternating with deep valleys. Although the relief most likely has been intensified since the glacier crossed this area, the area nonetheless even then had a pronounced southeastward-trending corrugation. Perhaps this corrugation acted as a barrier to the westward-flowing ice and prevented a largescale westward lobation of the ice margin coincident with the valley of the Bad River.

The general absence of till southwest of the Missouri River trench is attributed to the existence of the trench itself. Before any appreciable amount of ice reached the upland southwest of the Missouri River, the trench must have been filled to the brim with ice. This situation probably caused clean ice to move westward by shearing over the basal, dirt-laden ice lodged in the trench. The drift carried beyond the trench thus consisted principally of boulders that had, during transport, migrated into the upper, clean ice.

An obvious difficulty is evident if it is assumed that a glacier not only crossed the Missouri River trench in the Pierre area, but, in one place at least, extended 20 miles beyond the trench. If the Missouri River was blocked by this glacier, which it must surely have been, why was there no channel cut by melt water at the ice margin? Flint $(1949 \mathrm{~b}$, p. 69) suggested that melt water from the ice sheet as well as discharge contributed by the major eastward-flowing rivers was ponded by the ice to form large lakes in the valleys of these large tributaries of the Missouri. It was noted above that the drift border has a southeastward trend southeast of the Bad River and extends less than 11 miles south of the Missouri River trench east of Pierre. It therefore seems likely that this segment of the trench was clear of ice relatively soon after the ice margin had reached its outermost extent.

Additional evidence that the ice did melt back rapidly in this sector is provided by relations of contemporary proglacial outwash deposits. The outwash deposits in valleys tributary to the Bad River were graded to the alluvial fill in the Bad River trench (p. 29), which was, in turn, graded to a high-level valley train in the Missouri River trench east of Pierre. Thus melt water evidently continued to flow down the southeastward-trending tributaries of the Bad River after the ice margin had retreated northward and vacated the Missouri River trench east of Pierre. During the time that the glacier blocked the trench, melt water and drainage from the west probably were ponded in the valley of the Bad River.

The time of deposition of the erratics and proglacial outwash southwest of the Missouri River is suggested by the following points.

1. Flint (1949b, p. 70-71) pointed out that the Missouri River trench probably antedates the glacial drift southwest of it, because, had the trench not been present, there should be melt-water channels on the upland to the southwest. The absence of such channels indicates that an already existing escape route, the Missouri River trench, was available at the time of the most extensive glaciation. If the trench originated in the Illinoian stage the glacial drift west of the trench would, by this reasoning necessarily be of Wisconsin age.

2. The absence of till southwest of the Missouri River suggests that a trap must have existed for the basal, debris-laden ice. If the Missouri River trench had not been present, till should be as abundant to the southwest as it is to the northeast. This reasoning implies that the drift west of the Missouri is younger than the trench and is, therefore, of Wisconsin age.

3. All but a very few of the glacial erratics consist of rock not perceptibly weathered even at the surface. It is unlikely that these boulders would now be so fresh if they had been exposed to weathering processes throughout an interglacial stage. This inference points toward a Wisconsin age for the time of deposition of the erratics.

4. The ice sheet that crossed the trench, and that presumably was the source of the outwash deposits in the valleys of Dry Run and Willow Creek, was very likely the same glacier that deposited the erratics. It was noted above that these outwash deposits are graded to an alluvial fill of Iowan age in the Bad River trench which in turn is graded to an outwash valley train in the Missouri River trench.

The data available point toward a Wisconsin date for the time of deposition of the southwesternmost glacial drift in the area. On the evidence furnished by the outwash deposits in tributaries of the Bad River, it seems most lkely that the glacial drift southwest of the Missouri River is of Iowan age.

\section{DEPOSITS OF TAZEWELL SUBSTAGE}

Glacial drift of the Tazewell substage is the most widespread Pleistocene deposit in the Pierre area, with 
the possible exception of loess. 'This drift represents the deposits of the most recent glacier to reach the Missouri River trench in the Pierre area.

$$
\text { TILL. AND MORAINES }
$$

Till of Tazewell age, overlain by Tazewell and postTazewell loess, underlies the upland surfaces of the Oahe, Pierre, and Canning quadrangles northeast of the Missouri River. This till typically is fine-grained, with more than 6 o percent material in the silt and clay sizes, but contains unweathered cobbles and boulders as much as 10 feet in largest dimension. Its color ranges from dark-yellowish orange to moderate yellowish brown and moderate brown. With few exceptions the till is calcareous to within a few inches of the surface. In outcrops it is oxidized throughout, although in test holes near the east abutment of the Oahe Dam oxidation does not occur deeper than 50 feet. The maximum depth of oxidation in the till elsewhere in the Pierre area is not known.

Moraines in the Pierre area were described by J. E. Todd $(1894$, p. 115) in the first bulletin of the South Dakota Geological Survey; he referred to Snake Butte and Medicine Knoll as parts of the "first, or outer moraine." In subsequent publications, Todd (1896, $1902,1923)$ repeatedly referred to these two topographic features of the Pierre area as moraines, although he recognized that these relief features are largely composed of bedrock. Pierre shale is exposed at an altitude of about 1,830 feet at the west end of Snake Butte. It is likely that shale extends even higher under this part of the butte; however, a cover of colluvium has masked the contact of the shale and drift. The Corps of Engineers drilled several exploratory holes near the center of the butte and found that there, too, the relief of the ridge is chiefly caused by a core of Pierre shale and is only accentuated by a cover of glacial drift.

Northeast of the city of Pierre the upland is composed of glacial drift consisting predominantly of till. Within a mile or two of the trench the surface of the drift is nearly featureless because of the leveling effect of a loess cover 5 to 20 feet thick. Farther from the Missouri River, the drift has a local relief of about 10 feet despite a loess cover as much as $\mathbf{1 0}$ feet thick. The surface of the till consists of gentle swells and swales and, locally, closed depressions. This area of low-relief is interpreted and mapped as ground moraine.

$\Lambda$ broad low ridge, 1 to 2 miles wide and standing from 20 to 60 feet above the surrounding ground moraine, lies about 5 miles northeast of the city of Pierre. It is underlain by glacial drift and is charac- terized by a larger number of closed depressions and steeper slopes than are in the adjacent ground moraine. Because of its ridgelike form and its relatively greater amount of constructional topography than the surrounding ground moraine, this broad ridge is interpreter as an end moraine, and is informally referred to here as the Pierre end moraine. Although it appears to merge impreceptibly with ground moraine at each end, it has been traced from sec. 21, T. 111 N., R. 78 IV., in the Canning quadrangle, to sec. 14, T. 112 N., R. $80 \mathrm{~W}$., northwest of the Pierre quadrangle. This end moraine can not be traced south of Dry Run in the Canning quadrangle, but a concentration of erratics along the north wall of the Missouri River trench in the eastern part of the Pierre quadrangle and in the western part of the Canning quadrangle (fig. 15) possibly represents a southwestward continuation of the glacier terminus at which the end moraine was built. The end moraine continues northwestward beyond the north edge of the Pierre quadrangle to an intersection with the Missouri River trench.

From 1 to 3 miles northeast of the Pierre end moraine and separated from it by ground moraine, is a second end moraine informally referred to here as the Body Ranch end moraine, from 1 to 3 miles wide and 20 to 100 feet higher than the flanking ground moraine. This broad moraine, which extends from sec. 12, T. 110 N., R. 77 W., in the Canning quadrangle, to the northeast corner of the Pierre quadrangle, has the general plan of a large arc concave westward.

Although positive correlation has not been established, the drift of the Pierre and Body Ranch end moraines is believed to be of essentially the same age as the upper till deposits in the test pit and exposure at the airport. This correlation is based on tracing the

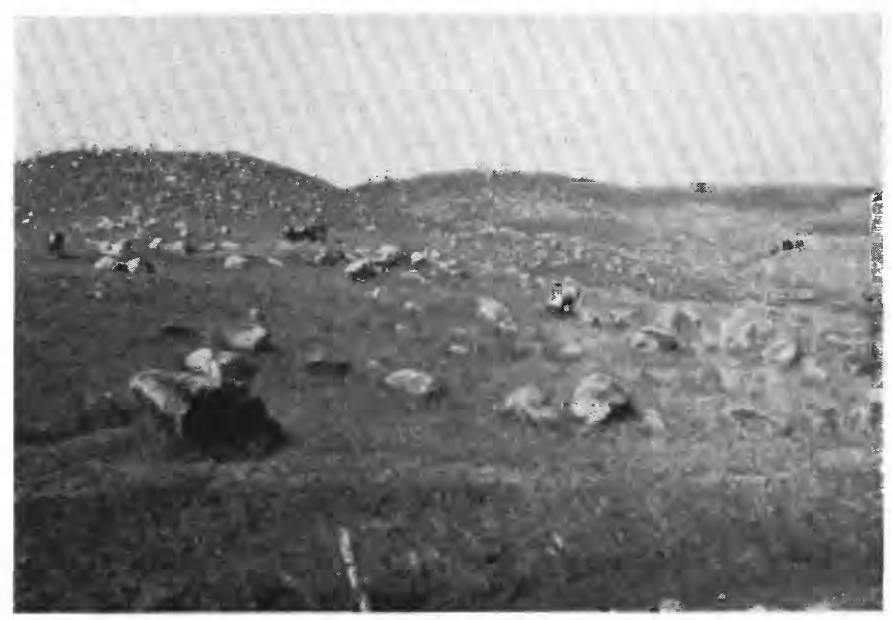

Figure 15.-Boulder concentration along north valley wall of Missouri River in the eastern part of the Pierre quadrangle. 
drift that occurs immediately beneath the surficial loess from one exposure to another from the airport into the end moraines. On this basis, the end moraines are here tentatively referred to the Tazewell substage.

The possibility that the two end moraines described above are bedrock ridges covered by ground moraine has been considered. The configuration of the moraines is related to preexisting inferred and known topographic features in such a manner, however, as to suggest that the end moraine interpretation is valid, although some of the height of the end moraine at Body Ranch hill might be caused by an underlying bedrock knob.

\section{STRATIFIED DRIFT}

Stratified drift of the Tazewell substage occurs as remnants of outwash valley trains in the trench of the Missouri River and in valleys tributary to it. No outwash identified with the Tazewell substage is known southwest of the Missouri River trench, and there are no known remnants of the alluvial fill in the Bad River trench that must have been deposited in this valley during the Tazewell substage.

The most continuous outwash deposit in the Missouri River trench in the Pierre area is preserved in large, terrace-topped remnants at the west end of Peoria Bottom; in secs. 5, 7, and 8, T. 5 N., R. 31 E.; north and south of Whisky Gulch in and adjacent to Pierre; and in secs. 1, 2, and 3, T. 109 N., R. 77 W. (fig. 16). They were referred to, respectively, by Rothrock (1944) as the Oahe terrace, Scotty Philips terrace, Polo Grounds terrace, and Fort George terrace. In addition, there are many small remnants of this outwash deposit along the north wall of the Missouri River trench between Pierre and Rousseau.

Although in many places this outwash deposit has been extensively dissected, locally there are still large remnants, nearly flat-topped, that probably nearly preserve the original surface of the deposit. In other places, loess deposits as much as 30 feet thick have mantled the upper surface of the outwash deposit. That these remnants are parts of a single continuous outwash valley train is indicated by a general correspondence in altitude of the terraces (fig. 16). The possibility that the terraces are merely features cut on an earlier outwash fill in the trench is disproven by the broad, almost flat bedrock straths on which the deposits lie, and by the fact that the outwash remnants do not extend up tributary valleys in the manner of fills.

The rock types represented in the outwash determined by pebble count are indicated below. Location: SE $1 / 4$ SW $1 / 4$ sec. 33, T. 111 N., R. 79 W.

$\begin{array}{lr}\text { Rock typc } & \text { Percent } \\ \text { Granite - } & 23 \\ \text { Gabbro and basalt } & 10 \\ \text { Pierre shale_- } & 1 \\ \text { Limestone - } & 33 \\ \text { Concretions, iron oxide, from Pierre shale-- } & 17 \\ \text { Chert and chalcedony } & 2 \\ \text { Quartz }\end{array}$

In most places the outwash consists predominantly of sand and pebble gravel with numerous cobbles and some very large boulders. In a small gravel pit in the SE1/4 SW1/4 sec. 33, T. 111 N., R. 79 W., there are many boulders as large as 8 feet in diameter, although the deposit otherwise is predominantly fine grained. The presence of large boulders seems to indicate that some of it accumulated when the margin of the Tazewell glacier was very close to, if not actually in, the Missouri River trench; some of this deposit may be of ice-contact origin.

The age of Tazewell tentatively assigned to this outwash deposit is based on extrapolations of the longitudinal profiles of outwash terraces from the Missouri River trench up tributary valleys to the end moraines of Tazewell age (fig. 16). This extrapolation can be made with greatest certainty in the valley of Spring Creek, a tributary that enters the Missouri River about 2 miles north of the northwest corner of the Pierre quadrangle. The outwash train in the valley of Spring Creek can be traced upstream into the Body Ranch and Pierre and moraines, and downstream the extrapolated surface of the valley train grades into the extrapolated surface of the outwash terraces in the Missouri River trench. A group of small outwash deposits lies in the valley of Dry Run near the east edge of the Pierre quadrangle, and in the Canning quadrangle. The surface altitude of the deposits ranges from 1,630 to 1,700 feet. Although the downstream equivalent of the deposits is lacking in the southward-trending segment of Dry Rum, the altitude and extrapolated longitudinal profile of the remnants indicates that they are part of an outwash valley train graded to the Tazewell outwash terrace deposits in the Missouri. Dry Run heads in the Body Ranch end moraine, and thus offers additional evidence that the outwash is of the same age as the moraine.

Vertebrate fossils were not found by the author in any of the glacial outwash deposits within the Missouri River trench, although a pair of mastodon teeth and a single mammoth tooth in the State Historical Museum at Pierre (Museum nos. 3043, 3044, and 3045, respectively) are reported to have come from a gravel pit in the Scotty Philips terrace of Rothrock. The mammoth tooth was identified by Dr. C. B. Schultz (written communication, February 24, 1950) as from "Mammuthus 


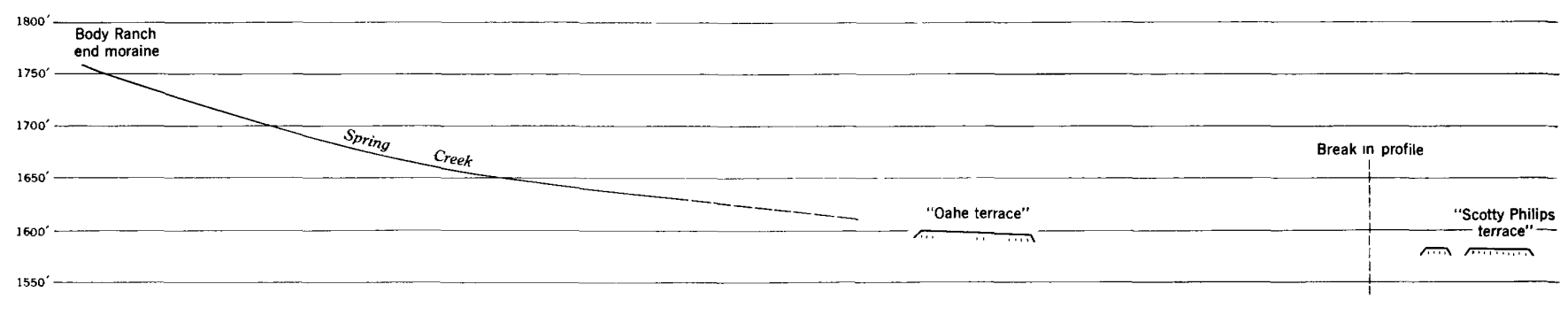

$1500^{\prime}$

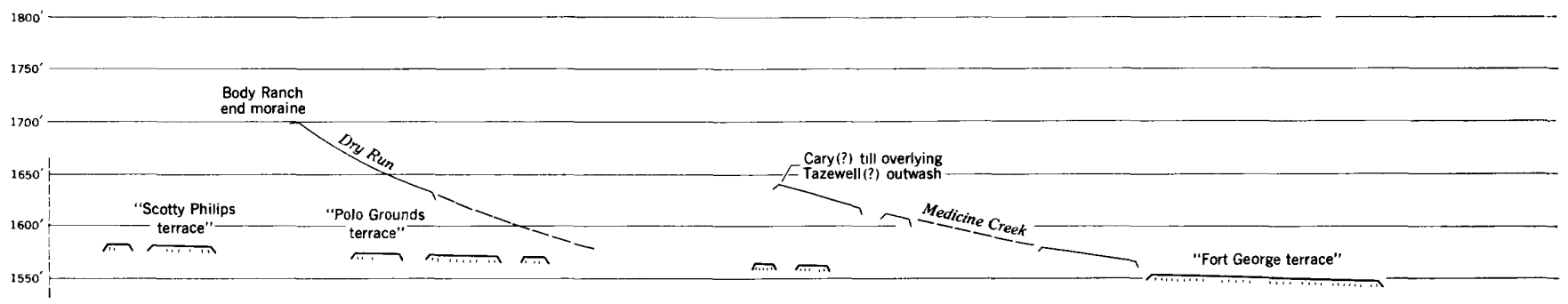

$1500^{\circ}$

\section{$100 \quad 8$ Miles}

Figure 16.--Longitudinal profiles of outwash terraces of the Tazewell substage in the Missouri River trench and its tributaries. Names of terraces are those of Rothrock (1944).

jeffersoni (Osborn) referred, Mammoth. Upper left molar 3." Schultz added that

This specimen is similar to late Pleistocene forms from the Nebraska region. Sangamon or later. The tooth shows a much more advanced stage of development than examples from the Sappa (Yarmouth) deposits.

The mastodon teeth were identified by Schultz as from "Mammut americanus (Kerr), America Mastodon. Upper left molars 2 and 3." He stated further that these specimens compare very favorably with late Pleistocene specimens of Sangamon or younger age from central North America.

An outwash deposit that does not appear to fit logically into the sequence of valley trains of Wisconsin age is located in the city of Pierre. The upper surface of the deposit lies at an altitude of about 1,485 feet. The material is very coarse; layers of cobble gravel and scattered boulders in pebble gravel are common. In general, the outwash ranges in thickness from 1 to 10 feet, and wherever the lower contact was observed, the deposit rests directly on Pierre shale. The South Dakota State Capitol Building in the NW1/4 sec. 4, T. 110 N., R. 79 W. is constructed on this deposit. Excavations in the summer of 1950 for a new office building and for a tunnel from the building to the capitol exposed the sand and gravel through a considerable distance. These exposures show that from 2 to 9 feet of material, ranging from sand to cobble gravel, orerlies Pierre shale and is overlain by 12 to 15 feet of loess that incorporates one, and locally two, buried soil profiles. This loess section and others like it, overlying the same deposit elsewhere in Pierre, are discussed in the section on loess (p. 38).

The coarseness of this deposit suggests that it was formed relatively close to an ice sheet, and inasmuch as the glacier margin of the Tazewell substage locally invaded the Missouri River trench, probably the deposit in question is of Tazewell age. The overlying loess with one, and in some places two, buried soil profiles likewise suggests that it is of Tazewell age. The surface of the deposit, however, is from 50 to 60 feet lower than the upper surface of the Tazewell outwash valley train described above in this part of the Missouri trench. The fact that the drift border of the Cary substage (fig. 14) is nearly 50 miles from Pierre by the shortest route for melt water seems to preclude a postTazewell age for the deposit because of its coarsegrained character.

This deposit is believed to have been formed in the following manner very shortly after the maximum of the Tazewell substage during intrenchment of the Missouri River in the Tazewell outwash deposits. As the river eroded down through the outwash, it also corraded laterally and locally cut straths on Pierre shale in the valley walls. The sediments left on these straths consisted of veneers of reworked glacial sand and gravel derived largely from the Tazewell outwash; after these straths were abandoned by further down- 
cutting, the reworked outwash was capped by loess deposits in which a soil profile developed during the time between the Tazewell and Cary substages.

Small remnants of coarse gravel along the valley wall of the Missouri in the Canning quadrangle at altitudes of 1,460 to 1,480 feet probably are of similar origin. All of these have been mapped as stratified drift of Tazewell age.

\section{SOUTHWESTERNMOST EXTENT OF TAZEWELL ICE}

In the Tazewell substage, a glacier locally reached and probably briefly occupied the Missouri River trench in the Pierre area. Till inferred to be of Tazewell age crops out nearly continuously at the rim of the northeast trench wall from the northeast corner of the Oahe quadrangle to Snake Butte, and from a few miles east of Pierre to the east edge of the Canning quadrangle. Very little till has been noted southwest of the trench; none is known to be of Tazewell age. Evidence is lacking that the Tazewell glacier crossed the trench and extended onto the upland to the southwest. A general thinness of till in the area bounded by the Missouri River trench, Snake Butte, and Hilgers Gulch suggests that the glacier of the Tazewell substage did not extend southwest of Snake Butte and Hilgers Gulch and thus did not reach the Missouri River in this segment.

A large concentration of glacial boulders along the north trench wall east of Pierre, which is inferred to represent a southwesterly continuation of the Pierre end moraine, indicates that the Tazewell glacier reached and temporarily lay within the Missouri River trench east of Pierre.

The inferred margin of the Tazewell glacier at its maximum extent is shown in figure 14 .

\section{DEPOSITS OF THE CARY SUBSTAGE}

Other than stratified drift in the trenches of the Missouri River and Medicine Creek, the only glacial drift of the Cary substage is in the Canning quadrangle northeast of Canning.

$$
\text { TILL }
$$

In mapping the Canning quadrangle several features were noted that suggest that a glacier of postTazewell age reached the northeast corner of the quadrangle. No single exposure of till, however, can be dated with certainty as of Cary rather than Iowan or Tazewell age. In the northeast corner of the quadrangle the surficial till is rich in clay, it is oxidized in most places, and it contains pebbles and boulders of unweathered igneous and sedimentary rocks. The lithology of this till is essentially identical to the till of
'Tazewell age at the test pit and at the airport. At several localities in and adjacent to the trench of Medicine Creek, however, unoxidized till that grades upward into oxidized drift has been noted. In the $\mathrm{SE} 1 / 4$ sec. 19, T. 111 N., R. 76 W., near the mouth of Dehart Draw, unoxidized till 5 to 10 feet thick underlies 15 to 20 feet of oxidized till. The oxidized till is mapped as ground moraine. A similar exposure of unoxidized till overlain by oxidized drift occurs in the NE1/4 SW1/4 sec. 18, T. 111 N., R. 76 W., in a valley tributary to Medicine Creek. The comparable zone of oxidation in the till of Tazewell age is 40 feet or more in thickness along the Missouri River trench. North of Canning, particularly in secs. $17,18,19$, and 20 , T. 111 N., R. $76 \mathrm{~W}$., till that has a constructional topographic expression extends from upland areas almost to the flood plain of Medicine Creek. In contrast, elsewhere in the Canning and Pierre quadrangles, till of Tazewell age in a corresponding topographic position no longer retains constructional topography.

Another feature suggestive of a glaciation subsequent to the Tazewell substage is the presence of large blocks of limestone in and weathering from the surficial drift adjacent to Medicine Creek near Canning. Limestone blocks of this size are not common on surfaces underlain by Tazewell till in the Pierre quadrangle and the western part of the Canning quadrangle. A reconnaissance in areas mapped by Flint (1955) as being underlain by drift of Cary and Mankato age in northeastern Hughes County, however, revealed many limestone erratics lying on the drift surface. This distribution suggests that the surficial drift sheet adjacent to Medicine Creek in the vicinity of Canning is of different age than that farther west. In order to determine whether this qualitative observation of a difference in distribution of limestone rocks was borne out by quantitative data, pebble counts were made from till outcrops at several localities. The following table shows the percentage of limestone pebbles in samples collected from the localities noted.

limestone pebbles

1. Tazewell till at test pit exposure

2. Tazewell till at the exposure at the airport___._.-- 25

3. Tazewell till at Pierre end moraine (SW1/4 sec. 9, T. 111 N., R. 78 W.)

4. Tazewell till at Body Ranch end moraine (NE1/4 sec. 1, T. 111 N., R. 78 W.)

5. Cary till, 4 miles east of Blunt (NE1/4 sec. 12 , T. 112 N., R. 76 W.)

6. Cary till, 1 mile east of Canning (overlying Tazewell outwash), (NW1/4 sec. 30, T. 111 N., R. 76 W.)

7. Cary till at 3 miles northeast of Canning (NW1/4 SW $1 / 4$ sec. 5, T. 111 N., R. $76 \mathrm{~W}$.) 
This study indicates that if the relative proportion of limestone pebbles has any age significance, the Pierre end moraine and drift east of it might be of different age then the tills of Tazewell age in the exposures at the test pit and the airport. It was noted above, however, that the upper tills in these two exposures are most likely correlative in age with the Pierre and Body Ranch end moraines.

As a purely qualitative observation, there are more limestone boulders in the drift of Cary age in the Canning quadrangle than in the drift of Tazewell age; this difference in proportion of limestone is not apparent in the pebble-sized component of the drift. As a criterion for mapping the distribution of the younger till, the distinction is not helpful, because, other than along the stream valleys, the surficial drift is covered by a blanket of loess, and boulders at the surface are not abundant.

A fourth line of evidence that suggests glaciation of the northeastern corner of the Canning quadrangle subsequent to the Tazewell substage is an exposure of till resting on outwash stratified drift of probable Tazewell age in the northeast corner sec. 30, T. $111 \mathrm{~N}$, R. 76 W. (fig. 17). The drift consists of medium- to coarse-grained sand and granule gravel with cut-andfill stratification. The deposit is oxidized throughout, but otherwise shows no evidence of a period of soil formation prior to the deposition of the overlying till. The till lies on the outwash with a sharp contact; the bedding in the outwash has not been deformed. The age of the till is not known; the percentage of limestone pebbles in it is given (No.6) above. However, because of its stratigraphic position, and because barely 1 mile

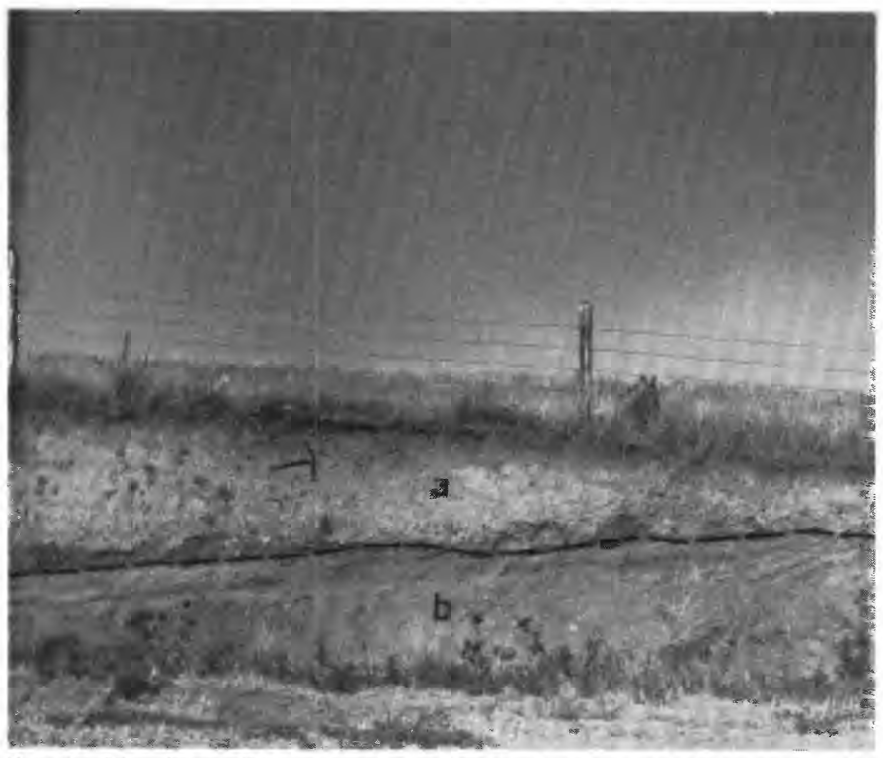

Figure 17. - Cary till (a) overlying Tazewell outwash $(b)$ in the northeast corner of sec. $30, T .111$ N., R. 76 W., southeast of Canning. west of this locality there is outwash inferred to have been deposited at or near the margin of a post-Tazewell glacier, it seems likely that the till in question is of Cary age.

In summary, although till of the Cary substage has not been identified with certainty in the Pierre area, the surficial till in the northeastern part of the Canning quadrangle is inferred to be of Cary age. This till appears to be lithologically similar to till of Tazewell age except for the shallower depth of oxidation, and the larger number of limestone boulders.

End moraines of the Cary substage have not been recognized in the Canning quadrangle. From 1 to 4 miles east of the quadrangle, however, both Flint (1955) and the author have recognized and mapped northwestward-trending moraines that have greater local relief and a less well-integrated drainage system than have the Pierre and Body Ranch end moraines. The end moraines just east of the Canning quadrangle are 10 miles or more west of the drift border of the Mankato substage mapped by Flint, and thus are inferred to be of Cary age.

In central Sully County, the drift border of the Cary substage was mapped by Flint (1955) coincident with the distal side of a broadly arcuate belt of end moraine west of Onida. The absence of a prominent end moraine marking the westernmost advance of the Cary glacier in Hughes County suggests that the outer margin of the ice was tangent to this line for a relatively short time.

STRATIFIED LRIFT

Outwash of the Cary substage cannot be differentiated with certainty from outwash of Tazewell age in the Missouri River trench. The nearest source of Cary outwash in the Missouri upstream from Medicine Creek is Okobojo Creek. It is nearly 25 miles downstream to the Missouri River (fig. 14) from the point where Okobojo Creek leaves the western edge of the Cary drift mapped by Flint (1955). It is about 20 miles farther from the mouth of Okobojo Creek to Pierre, via the Missouri River. It appears likely that in a distance of nearly 50 miles, sediments from the Cary glacier would be well sorted for size with respect to increasing distance from the source. Accordingly it is inferred that stratified drift of Cary age in the Missouri River trench at Pierre, if indeed any drift of this substage is present, is relatively fine grained and contains few or no cobbles and boulders.

Subsurface exploration at the site of the Oahe Dam and excavations for piers of the highway bridge across the Missouri River at Pierre indicate that the lowest point on the bedrock floor of the trench is at an alti- 
tude of about 1,360 feet. The altitude of the flood plain in that vicinity ranges from 1,420 to 1,440 feet; thus there is valley fill 60 to 80 feet thick underlying the flood plain. Drill logs of this fill at the Oahe Dam site, provided by the Corps of Engineers, U. S. Army, indicate that the sediment is predominantly fine grained, with approximately 90 percent of the material sand sized or smaller. Included in this fine-grained material are lenses of pebble gravel. Whereas the competence of the Missouri River at flood stage probably is great enough to transport all sizes of the alluvium beneath the flood plain, at least the basal parts of this fill probably have remained undisturbed since original deposition. This is inferred from the discovery of the skull of a bison of Wisconsin age (identified by C. B. Schultz, written communication, July 8, 1952) near the bottom of an excavation for a pier of the highway bridge (fig. 18). The skull shows no wear or breakage as would be expected had it been moved since the original deposition of the outwash in which it was found.

Exposures of outwash of Cary age above the altitude of the Missouri River flood plain have not been identified with certainty. A deposit tentatively referred to the Cary substage is situated adjacent to the Missouri River in the northwest part of the city of Pierre. This deposit consists predominantly of silt and fine- to medium-grained sand, interbedded with lenses of pebble gravel. The surface of the outwash lies at an altitude of about 1,440 feet. The possibility that this deposit is of Tazewell age has not been disproved, but its relatively fine-grained nature is at least consistent with its tentative assignment to the Cary substage.

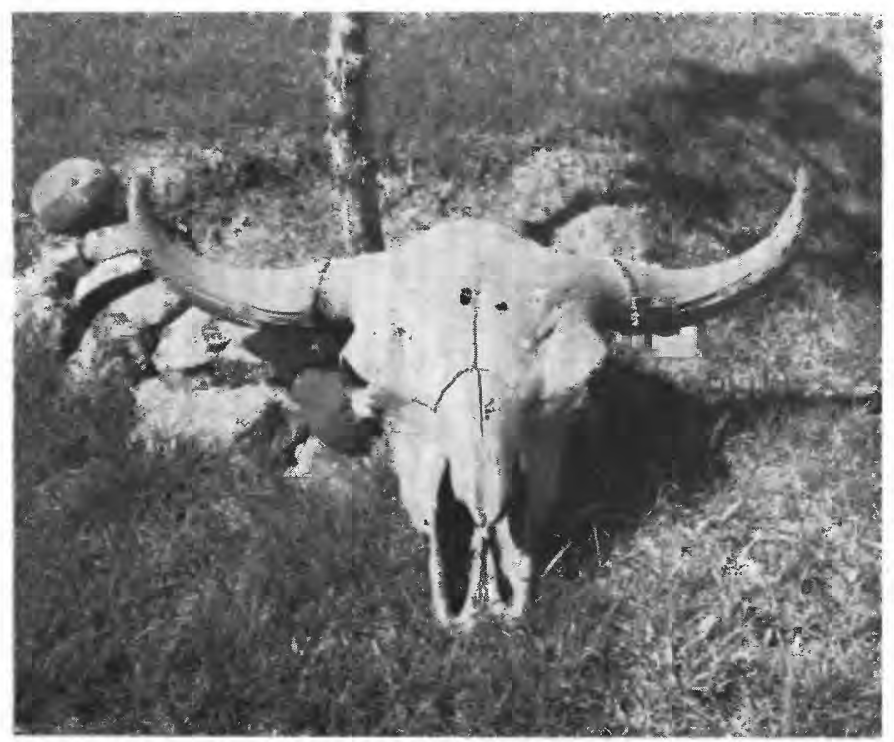

FIGCRe 18.-Bison skull from late Wisconsin outwash beneath the Missouri River flood plain at Pierre. The spread of the horns is 33 inches, the distance between the bases of the horns, 15 inches, and girth of each horn at the base, 12 inches.

$452631-58-4$
The valley of Medicine Creek contains remnants of a coarse outwash valley train. In the NW1/4 sec. 30 , T. 111 N., R. 76 W., an extremely coarse deposit of outwash, consisting of cobble and boulder gravel, lies about 70 feet below the surface of the outwash of Tazewell age at the same locality. This vertical relationship suggests that the lower deposit likely postdates the stratified drift of Tazewell age and is of Cary age. The coarse grain size of the younger outwash seems to indicate that it was deposited very near, if not immediately at, the margin of the glacier. The surface of this deposit lies at an altitude of about 1,555 feet.

Downstream from Canning, the next outwash deposit tentatively identified as of Cary age is in the NE $1 / 4$ NW1/4 sec. 14, T. 110 N., R. 77 W. Here a deposit of sand and gravel that contains boulders as large as 6 feet in diameter extends from a short distance above the Medicine Creek flood plain to an altitude of more than 1,520 feet.

The most extensive outwash deposits of Cary age above the Missouri River flood plain are in the southeastern part of the Canning quadrangle and in the area immediately adjacent to the east. 'These deposits probably were derived from the Cary glacier when it was in the vicinity of Canning, and brought to the Missouri River trench via Medicine Creek. The surface of these deposits lies at a lower altitude than does the surface of the Tazewell valley train in this area, and the overlying loess deposits lack a buried soil profile.

$$
\text { WESTERNMOST EXTENT OF CARY ICE }
$$

The westward limit of glaciation in the Cary substage shown in figure 14 is based on the occurrence of very coarse outwash of Cary age in the trench of Medicine Creek at Canning and on topography of the drift surface. A large concentration of erratics along the east side of a northward-trending ridge southeast of Canning (about 1 mile east of and parallel to the quadrangle boundary) suggests that this ridge baffled out much of the load carried in the basal parts of the ice sheets that crossed it. For a distance of a mile or more west of the ridge crest, drift is thin or scarce. The ridge probably was a barrier to the Cary glacier; on the basis of this inference the ice margin at the maximum of the Cary substage is shown as trending along the east side of the ridge. North of Canning the ice margin probably extended westward to an altitude of about 1,700 feet and trended northward, staying east of the crest of Medicine Knoll, to Blunt, North of Blunt the margin has been mapped by Flint (1955) as trending northwestward to Okobojo Creek in central Sully County. 


\section{DEPOSITS OF THE MANKATO SUBSTAGE}

The southwestern edge of the Mankato drift sheet trends northwestward through central Hyde County to east-central Sully County, and passes through the extreme northeast corner of Hughes County (fig. 14) 15 miles or more east of the Canning quadrangle. Accordingly till of Mankato age does not crop out in the Pierre area. Flint (1955) noted that both the north and south branches of Medicine Creek contain stratified drift of Mankato age derived from the glacier lobe in Hyde and Sully Counties.

In the $\mathrm{NW} 1 / 4$ sec. $23, \mathrm{~T} .110 \mathrm{~N}$., R. 77 W., half a mile upstream from the mouth of Medicine Creek, there are exposures of silt and fine sand containing layers of medium sand and pebble gravel. The surface of this deposit is at an altitude of about 1,460 feet. A similar deposit lies at about the same altitude on the west valley wall directly opposite. These deposits of finegrained sediment are about 25 miles downstream from the drift border of the Mankato substage. They lie nearly 50 feet topographically below coarse sand and gravel of Cary age. On the basis of these relationships it is suggested that the lower, fine-grained sediments are outwash of possible Mankato age. In most places in the valley of Medicine Creek, outwash of the Mankato substage has been covered by flood-plain deposits.

Although stratified drift of Mankato age probably is present in the material underlying the Missouri River flood plain, outwash of this substage has not been differentiated on the geologic maps (pls. 1, 2,3) from outwash sand and gravel of Cary age.

\section{DEPOSITS OF RECENT AND PLEISTOCENE AGE}

\section{LOESS}

The origin of a widespread blanket of silt that mantles much of the Pierre area is inferred by analogy with present conditions. On windy days clouds of sediment are blown from alluvium exposed in bars in and adjacent to the Missouri River; much of the sediment is deposited within the trench walls, but the finegrained fraction is transported beyond the trench. The silt-sized fraction that settles out is termed loess. It is megascopically indistinguishable from loess deposited during the Wisconsin stage.

\section{DESCRIPTION}

Loess is widely distributed in the region surrounding Pierre, but is thicker and more continuous on the east side than on the west side of the Missouri River. Northeast of the river, loess as much as 30 feet thick mantles glacial sand and gravel, till, Pierre shale, and terrace alluvium. On upland areas southwest of the
Missouri, the loess generally is 1 to 2 feet thick and is patchy.

The conditions that favor accumulation of loess are: an adequate source of fine, loose sediment; lack of vegetation or moisture to hold the sediment in place; winds sufficiently strong to deflate the loose sediment; and suitable topography. Whereas ideally the effect of these factors should be considered individually, in practice the effect of one is difficult to distinguish from the effect of another. For example, in the Pierre quadrangle loess that overlies till on the upland north of Snake Butte and adjacent to the Missouri River trench generally is from 12 to 20 feet thick. In sec. 25 , a short distance north of Stony Hill, the loess is from 1 to 3 feet thick. It might be infered that the relative thinness of the loess in sec. 25 is caused by the location of the area in respect to source area and direction of prevailing winds. The nearest source of material for northwest winds is the Missouri River flood plain about 5 miles to the northwest. In the case of southerly winds, the flood plain is close at hand; however, a large tributary valley in sec. 26 probably tends to channelize sediment-laden winds rising from the flood plain. The area is sec. 25 thus appears to be avoided by the winds that would favor thick loess accumulation. Still another factor must be considered: in the western half of sec. 25 , the surface is directly underlain by Pierre shale, a relationship that seems to retard loess accumulation elsewhere in the Pierre area, most notably southwest of the Missouri River trench. The relative responsibility of these several factors in determining loess thickness cannot be determined in an investigation of this scope.

The end moraines present another factor that influences loess thickness; slopes on these moraines are relatively steep and much of the loess originally deposited on the tops and flanks of knolls has since been removed by rainwash, whereas, in the swales, loess accumulation has been favored both by original deposition and by addition of material washed in from adjacent slopes.

The greatest thickness of loess in the area occurs along the east wall of the Missouri River trench north of Pierre; eastward the average thickness diminishes to about 12 feet at $1 \frac{1}{2}$ miles, to about 8 feet at 3 miles, and to 3 feet at 5 miles. This relationship implies that the principal source area of the loess was in the Missouri River trench north of Pierre, and that westerly and northwesterly winds were more effective in loess deposition than were southerly or southeasterly winds.

No pre-Wisconsin loess has been identified in the Pierre area. There is no loess stratigraphically beneath the Iowan till or between the Iowan and Tazewell drift deposits at the few places where these occur in super- 
position. All the loess that occurs in the area therefore appears to be of Tazewell and post-Tazewell age. The terminology of loess sheets used in this report follows the usage of Flint (1955) and is presented below.

Loess overlying Tazewell drift and underlying a well-developed soil profile Tazewell

Loess overlying Tazewell drift and extending to surface

Tazewell and post-Tazewell

Loess overlying Cary drift or a well-developed soil profile and extending to surface_____________________ Cary and post-Cary

Distinctive features by which Tazewell and postTazewell loess can be differentiated were not found, although much field time was consumed in drilling auger holes and in inspecting vertical exposures of the loess.

Data on the depth of leaching in southeastern South Dakota (Flint, 1949a) indicates that there is an average depth of leaching of 29 inches on drift of Cary age. In that region the mean annual precipitation is from 24 to 26 inches. In Charles Mix County, west of that region, the average yearly precipitation is 20 to 24 inches and the average depth of leaching on drift of Cary age is 15 inches. Thus, on drift of the same age, depth of leaching is proportional to amount of precipitation.

At Pierre, the depth of leaching is of little aid in subdivision or correlation because, with few exceptions, both till and loess are calcareous throughout, even to the present grass roots. Howard (1946) suggested that the cause of this was the net evaporation at the surface in arid and semiarid regions. The loss of water at the surface causes moisture to be drawn from below by capillary attraction. This moisture brings with it in solution calcium carbonate, that, upon evaporation of the water, is precipitated in the upper part of the material underlying the surface.

In general in the Tazewell substage, in areas within or close to the Missouri River trench, as much as 11 feet of loess accumulated, whereas several miles from the trench only 2 to 3 feet were deposited. These figures are based on thickness of loess underlying and including buried soil profiles. Cary and post-Cary loess, where separated from Tazewell loess by a buried soil profile, is as much as 10 feet thick within the Missouri River trench.

\section{FAUNA}

Fossils were found in loess in the SW1/4 sec. 21, T. 111 N., R. 79 W. A. B. Leonard (written communication, March 17, 1951) identified the following gastropods.

Helisoma trivolvis (Say)

Lymnaea palustris (Muller)

Gyraulus parvus (Say)

Lymnaea exilis (Lea)
Menetus exacuous (Say)

Lymnaea rustica (Lea)

Pisidium sp.

Retinella indentata (Gould)

Vertigo milium (Gould)

In regard to the age of these forms, Leonard stated: I am not able to place the assemblage stratigraphically, but since none of the species is extinct locally -in terms of the general area-I should say that the deposits from which these snails came is no older than late Wisconsinan. Ecologically, the fauna represents the assemblage of a rather permanent pond. All these species, except the last two (Retinella and Vertigo) live in such a situation. The last two are terrestrial species that live in timber or at timber borders.

\section{BURIED SOIL PROFILES IN LOESS}

In many places in the Pierre area, one or more buried immature soil profiles in loess have been observed. These soil profiles consist of the following layers or horizons:

3. oxidized, partly leached, humified material ( $A$ horizon).

2. oxidized, unleached material, may be enriched in clays, colloids, and secondary calcium carbonate ( $B$ horizon).

1. oxidized, unleached material.

In all outcrops and in nearly all auger holes the loess is oxidized throughout. In several instances, however, loess in a buried soil profile is oxidized to a greater extent than the loess occurring between the buried soil and the surface.

The most common soil profile noted is one that consists of an incomplete development of layer 3, the only feature to set that layer apart from the loess above and below is a humified zone 4 to 18 inches thick. Less commonly the humified layer is partly leached and a zone of secondary calcium carbonate lies beneath the humified material. A zone of more intense oxidation beneath the humified layer occurs in a few loess sections (fig. 19).

The time value of the soil profiles of varying degree of development is not known except in qualitative terms. It seems likely that more fully developed soil profiles record relatively longer time intervals between periods of loess accumulation. It is unlikely that a "profile" that consists only of a buried humified zone has much stratigraphic importance; such a zone probably could be developed in the space of a few decades or less under optimum conditions. Such conditions are illustrated in the Pierre area. There are many swells and swales in the end moraines and ground moraine of Tazewell age north and east of Pierre. Many of the swales remain moist throughout summer months, and vegetation persists there long after desiccation has retarded plant growth in adjacent, less moist areas. 


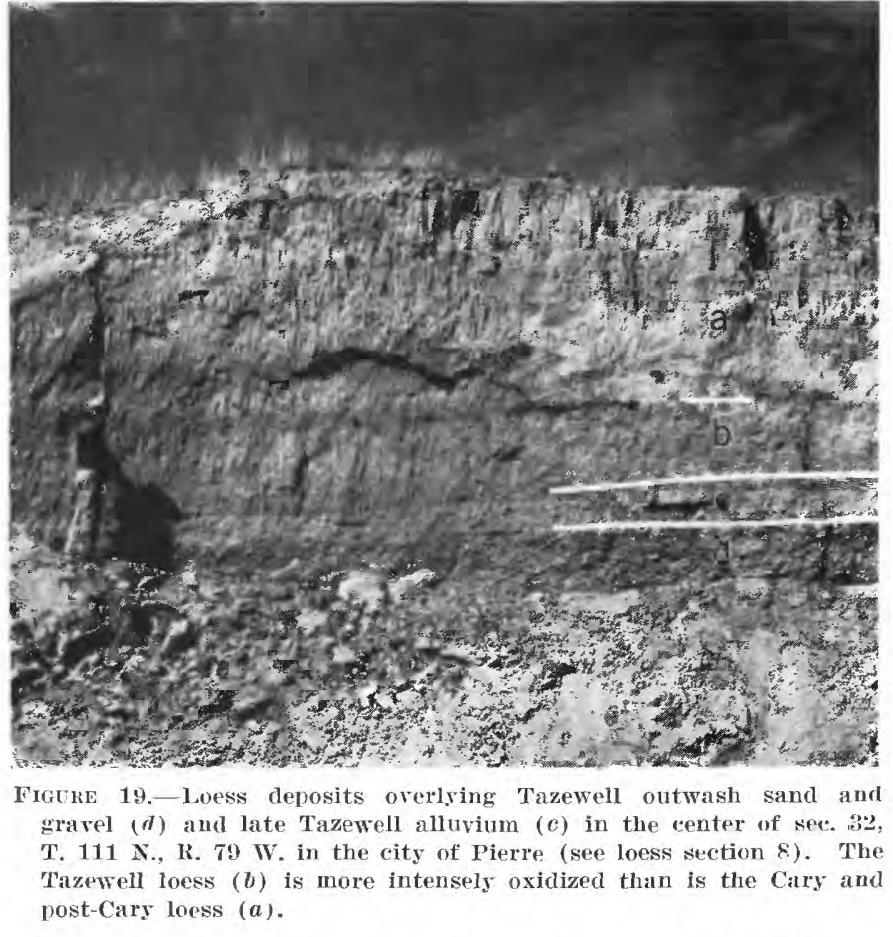

Moreorer, the swales act as traps for humus-rich sediment that creeps in and is washed in from adjacent slopes during the wet season. A result is to produce a humified zone several feet thick in the swales, whereas in an adjacent, higher area the humified zone of the soil may be but a few inches thick. If the swale deposit were to be mantled by a loess deposit in the future, an anger hole in it would reveal a very thick humified zone that would be difficult to reconcile with the evidence from another auger hole a few hundred yards away.

This relationship has been observed in many auger holes in the loess, wherein a buried humified zone does not extend laterally more than several hundred yards. Such a buried humified zone occurs in a road cut through the crest of Snake Butte. When the section was first examined there appeared to be two buried soil protiles in the loess overlying till. When the exposure subsequently was studied in greater detail, it was found that the humified zones merged laterally, and the general shape of the humified zone in cross section indicated that it was a filled depression in the surface of the till.

In most of the loess sections overlying drift of Tazewell age in the Pierre area there is one conspicuous buried soil profile. This is a more mature soil profile than those in loess overlying the Cary and Mankato drift sheets elsewhere in South Dakota. During the past several years evidence has been steadily accumulating that the most significant break in South I)akota and adjoining states between successive glaciations during the Wisconsin stage was the Tazewell-Cary interval (Flint, 1955; Ruhe, 1950). Therefore it is likely that the more mature soil profile in loess overlying the Tazewell drift in the Pierre area was formed in the Tazewell-Cary interval. The presence of a second buried soil profile in two loess sections is interpreted as recording the interval between the Cary and Mankato substages. The possibility exists, however, that the second soil profile is younger than the Mankato substage. Because of the uncertainty regarding the age of the soil profiles, the age assignments following each loess section in which a buried soil profile occurs must be regarded as tentative.

1. Luess section, NE1/4 sec. $28, T .112 \mathrm{~N} ., \mathrm{R} .79 \mathrm{~W}$.

4. Loess, humified (recent soil) less than

3. Loess, moderate-yellowish-brown

2. Loess, humified

1. Till

Tentative age assignments:

3 and 4. Cary and post-Cary.

2. Soil developed in Tazewell-Cary interval in Tazewell loess.

1. Tazewell.

2. Loess section, $N W 1 / 4$ sec. $29, T .111 N ., R .78 W$.

4. Loess, moderate-yellowish-brown Feet

3. Colluvium

2. Loess, humified, olive-black, leached

1. Till

Tentative age assignments:

3 and 4. Cary and post-Cary.

2. Soil developed in Tazewell-Cary interval in Tazewell loess.

1. Tazewell.

3. Loess section, SW1/4 sec. 6, T. $111 \mathrm{~N} ., \mathrm{R} .79 \mathrm{~W}$.

4. Loess, moderate-yellowish-brown Feet

3. Loess, humified, partly leached; concentration of cal-

cium carbonate at base___ 1.3

4. 0

2. Loess, mottled, dusky-yellow and yellowish-gray_----- 11. 0 1. Till.

Tentative age assignments:

4. Cary and post-Cary.

3. Soil developed in Tazewell-Cary interval in Tazewell loess.

2. Tazewell.

1. Tazewell till.

4. Loess section, NW1/4 sec. $31, T .112 \mathrm{~N} ., \mathrm{R} .7 \mathrm{~W}$ W.

5. Loess, humified (recent soil)

4. Colluvium, brownish-black to grayish-brown

3. Loess, moderate-yellowish-brown

2. Loess, humified

1. Loess, mottled, dusky-yellow and yellowish-gray
Feet

1

2

3

1 
Tentative age assignments :

3,4 , and 5. Cary and post-Cary.

2. Soil developed in Tazewell-Cary interval in Tazewell loess.

1. Tazewell.

5. Loess section, southuest corner of sec. $15, T .111$ N., R. $78 \mathrm{~W}$.

5. Loess, humified (recent soil)

4. Loess, moderate-yellowish-brown

3. Loess, humified__... 1.5

2. Loess, mottled, light-olive-gray and dusky-yellow_-_-_ 2.0

1. Till.

Tentative age assignments :

4 and 5 . Cary and post-Cary.

3. Soil developed in Tazewell-Cary interval in Tazewell loess.

2. Tazewell.

1. Tazewell.

6. Loess section, southwest corner of sec. $32, T .111 \mathrm{~N}$., R. $77 \mathrm{~W}$

4. Loess, humified (recent soil)

Feet

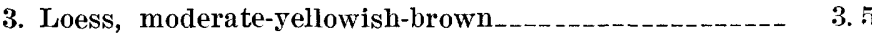

2. Loess, humified

1. Till.

Tentative age assignments :

3 and 4. Cary and post-Cary.

2. Tazewell-Cary soil in Tazewell loess.

1. Tazewell.

7. Loess section, northeast corner of sec. $14, T .111 \mathrm{~N}$., R. $7 \mathrm{Y} \mathrm{W}$

5. Loess, humified (recent soil) _-_ 0.5

4. Loess, moderate-yellowish-brown

3. Loess, humified, brownish-black_____._-_._- 1. 0

2. Loess, mottled, dusky-yellow and yellowish-gray

1. Till.

Tentative age assignments:

4 and 5 . Cary and post-Cary.

3. Soil devedoped in Tazewell-Cary interval in Tazewell loess.

2. Tazewell.

1. Tazewell.

In general, the loess overlying outwash deposits in the Missouri trench is thicker than loess of equivalent age overlying till on the upland surface adjacent to the trench. This is primarily due to distance from source area and the difference in vertical relief between the floor of the trench and the adjacent upland. In addition, the permeable nature of sand and gravel allows water to soak into it; in the case of shale, water runs off and thus removes any loess that has accumulated. This factor of great permeability also is characteristic of the loess, so that, once deposited, it is less susceptible to erosion than are less permeable materials.

Exposures and auger holes in which one or more buried soil profiles have been recorded in loess over- lying outwash deposits of Tazewell age are described below.

8. Loess section, center sec. 32, T. 111 N., R. 79 W. (fig. 19)

7. Loess, pale-yellowish-brown to yellowish-gray___-_ $\quad 8.5$

6. Loess, humified, dark-yellowish-brown

5. Loess, pale-yellowish-brown to dusky-yellow__._._._ 3.0

4. Loess, humified, dark-yellowish-brown to duskyyellowish-brown -.-.-.

3. Loess, yellowish-gray to dusky-yellow, contains some secondary calcium carbonate, more intensely oxidized than loess above or below

2. 0

2. Sand, fine, and silt and clay; horizontally laminated-- 2.0

1. Sand and gravel; includes boulders as large as 6 $\mathrm{ft}$ in diameter....... 10.0

Tentative age assignments :

5 to 7 . Cary and post-Cary.

6. Humified zone in Cary loess.

3 and 4. Soil profile developed in Tazewell-Cary interval in Tazewell loess.

1 and 2. Tazewell.

9. Loess section, SW1/4 sec. 3.3, T. 111 N., R. $79 \mathrm{~W}$.

6. Leess, humified

5. Loess _-

4. Loess, humified

3. Loess _-

2. Sand and silt

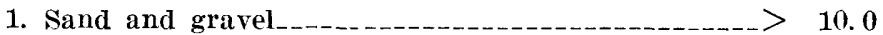

Tentative age assignments:

7. Cary and post-Cary.

6. Soil developed in Tazewell-Cary interval in Tazewell loess.

3 to 5. Tazewell.

4. Humified zone in Tazewell loess.

1 and 2. Tazewell.

10. Loess section, SE1/4 sec. 3, T. 110 N., R. ร9 W.

4. Loess

3. Loess, humified

2. Loess -_. 2.0

1. Sand and pebble to cobble gravel, contains boulders as large as $2 \mathrm{ft}$ in diameter._._._._._._._._._._.

Tentative age assignments :

4. Cary and post-Cary.

2 and 3 . Soil developed in Tazewell-Cary interval in Tazewell loess.

1. Tazewell.

11. Loess section, NE1/4 sec. 4, T. 110 N., R. 79 W.

6. Loess

Feet

5. Loess, humified; zone of secondary calcium carbonate at base

4. Loess

1.5

3. Loess, humified; zone of secondary calcium carbonate locally present at contact of units 3 and 2

3. 0

2. Sand and pebble to cobble gravel

1. 0

1. Pierre shale. 
'Tentative age assignments:

6. Post-Cary.

4 and 5. Soil developed in Cary-Mankato interval in Cary loess.

3. Soil developed in Tazewell-Cary interval in Tazewell loess.

2. Tazewell.

12. Loess section, SW1/1 sec. $8, T .5$ N., R. 31 E.

4. Loess

3. Loess, humified

2. Silt, sand, and elay

1. Sand and gravel.

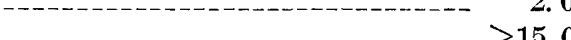

'Ientative age assignments:

t. Cary and post-Cary.

3. Soil developed in Tazewell-Cary interval in Tazewell loess.

1 and 2. Tazewell.

13. Loess section NE1/4 sec. 27, T. 111 N., R. $79 \mathrm{~W}$.

4. Loess _... 2.0

3. Loess, humified

2. Loess -

1. Silt and sand_... $>2.0$

Tentative age assignments:

4. Cary and post-Cary.

2 and 3 . Soil developed in Tazewell-Cary interval in

Tazewell loess.

1. Tazewell.

Many additional loess sections have been examined, overlying both till and stratified drift. Because the 13 sections given above represent localities at which buried soil profiles furnish evidence of periods of weathering, they are considered to be of some stratigraphic importance. So far as now known, color or thickness of the losses in the Pierre area has no bearing on the age either of the loess or the underlying glacial drift.

\section{RATE OF LOESS ACCUMULATION}

The only data available on the rate of recent loess accumulation are provided by an examination of Indian villages. One of these, in southeastern Stanley County a short distance southeast of the Canning quadrangle, was visited by the author accompanied by $\mathrm{Mr}$. E. E. Meleen, assistant soils engineer, South Dakota State Highway Department, who supervised some archaeological work at this village site several years ago. The village is situated on a loess-covered deposit of outwash sand and gravel less than 150 yards south of the present flood plain of the Missouri River. The locality is one very favorable for loess accumulation. Details of the archaeological excavation were furnished by Mr. Meleen and the relationships were verified by the author in the field. A maximum of about 5.5 feet of undisturbed loess had accumulated in the deepest part of one of the former lodge pits since the site was occupied. Cedar posts found in the lodge pit were sent by Mr. Meleen to Mr. George W. Will of Bismarck, N. Dak., for determination of age by means of a treering analysis. A letter written by $\mathrm{Mr}$. Will to $\mathrm{Mr}$. Meleen stated that the "timbers" were dated as having been cut between the years 1480 and 1487. The following precautionary notes were added by $\mathrm{Mr}$. Will:

I must caution you as to all the dates I am supplying, that there is a wider variation between the timbers from South Dakota and $\mathrm{my}$ North Dakota Key chart than there is between the North Dakota timbers and the chart. You realize, of course, that nearly all of the timbers had considerable wood on the outside which cannot be read, so that the dates given would be some years short of the actual cutting dates. It is, also, well to remember that timbers were often removed from older village sites, so that there might be quite a range in age between timbers from the same village.

Subject to the conditions stated above by Mr. Will, it appears that the occupation surface at the Indian village is about 460 years old. A maximum of 5.5 feet of loess was recorded overlying this surface in depressions and 2 feet on flat surfaces. The rate of loess accumulation that can be derived from these data undoubtedly is much higher than the rate of deposition in areas less favorably situated than this particular site.

A second Indian village at which loess deposits have covered lodge pits is in the NW1/4 sec. $27, T .112 \mathrm{~N}$., R. $81 \mathrm{~W}$., at the northwest end of the broad outwash terrace in the northeastern corner of the Oahe quadrangle. One lodge excavated at this site was buried by 1.5 to 4 feet of loess since it was occupied (Meleen, 1949, p. 313). Tree-ring data on timbers taken from this lodge suggest that the site was occupied about $1480 \mathrm{~A}$. D., or about 475 years ago.

Travertine deposits are present at one locality in the Pierre quadrangle and at 5 localities in the Canning quadrangle. The travertine occurs principally as a cement in outwash sand and gravel and as cellular masses enclosing fragments of vegetation.

The deposits range in thickness from 3 to 15 feet and are limited areally to outcrops a hundred yards or less in width and length. Because of their resistance to erosion, however, the deposits form prominent ledges, especially where the travertine has cemented outwash sand and gravel.

In the course of geologic mapping, present deposition of calcium carbonate was noted only in The Drips, a valley tributary to Medicine Creek in sec. 11, T. 110 N., R. $77 \mathrm{~W}$. in the Canning quadrangle. At other localities flowing springs occur in the same general areas as travertine deposits, and in still other places, travertine deposits are far from any flowing springs or seeps. 
Some of these deposits probably formed at some time in the past when heavier precipitation caused a higher ground-water table in the area.

In some places the travertine deposits are situated on ridges between adjacent gullies. It is inferred that the gullies are much younger than the spring deposits and that there might have been a reversal of topography on a small scale: the spring deposit marks the original gully floor which subsequently was preserved because of its greater resistance to erosion than the adjacent Pierre shale or glacial drift.

\section{LANDSLIDE DEPOSITS}

Landslide deposits are widely distributed in the Pierre area. Almost nowhere can contacts between members of the Pierre shale and between subdivisions of glacial drift be followed for more than a few hundred yards before the contact either is displaced by a slump or covered with the deposit of some other masswasting process. ${ }^{7}$ Many small slope failures, some not more than a year or two old, can be seen on the sides of nearly every stream valley in the area. It is estimated that at least 75 percent of the material exposed in the valley walls of the Missouri and Bad Rivers and Medicine Creek and the tributaries of these rivers has been moved to some extent by mass-wasting processes; areas of disturbed material in most of the tributary valleys were not mapped because of a general lack of outcrops adequate to delimit individual slide deposits.

The nature of landslides in the Pierre area is discussed in a subsequent section on engineering geology (p. 70-71).

\section{FAN DEPOSITS}

Broad, gently sloping areas between alluvium of the valley floors and outcrops of shale and glacial drift in valley walls are fan alluvium and colluvium. The alluvium is transported and deposited by slope wash from the valley walls and by streams debouching from the mouths of gullies onto the fans. The colluvium consists of mudflow deposits derived from weathered Pierre shale in the gully walls. In many areas, adjacent fans have coalesced laterally to form a single broad slope as much as several miles long and half a mile wide. These coalescent alluvial fans are most prominent in the western part of Peoria Bottom, along the west valley wall of the Missouri River north of Pierre, and between Mush and Medicine Creeks along the north valley wall of the Missouri in the Canning quadrangle.

Fan deposits also include veneers of alluvium on shale along the margins of the valley floors; the surface

\footnotetext{
7 Mass wasting is defined as the downslope movement of earth material under the influence of gravity.
}

of the shale slopes toward the center of the valley floors and appears to have been cut by sheetwash and lateral erosion by tributary streams. A distinction is not made here between alluvial fan deposits and the deposits on these sloping shale surfaces which have the outward appearance of alluvial fans.

Where fan deposits are located downslope from outcrops of glacial drift, the alluvium and colluvium contains sand and gravel; the fan deposits downslope from Pierre shale outcrops, are largely reworked shale. The thickness of the deposits ranges from a featheredge to 30 feet; most commonly it is 5 to 15 feet.

\section{DEPOSITS OF RECENT AGE}

Valley floors are underlain by flood-plain alluvium ranging in thickness from a few feet to about 80 feet. Drill $\operatorname{logs}$, provided by the Corps of Engineers, U. S. Army, of this alluvium beneath the Missouri River flood plain at the Oahe Dam indicate that there the sediment is predominantly fine-grained with approximately 90 percent of the material of sand size or smaller. Included in the fine-grained alluvium are lenses of pebble gravel. Some of the alluvium beneath the flood plain, especially the lower parts of the alluvial fill, very likely is glacial outwash that was deposited during the Cary and Mankato substages. Alluvium now being carried by the Missouri River is typically fine and very fine sand, silt, and clay. Some of this sediment is deposited to form bars in late spring and early summer as discharge decreases. Most of the bars are destroyed the following spring during highwater stages, but some persist until vegetation is well established. The bars then become semipermanent islands which receive an increment of alluvium during each succeeding high-water stage of the river. Wood, Laframboise, and Farm Islands appear to have originated in this way.

A power auger penetrated, from top to bottom, 25 feet of fine and very fine sand, 20 feet of coarse sand and pebble gravel, and 25 feet of coarse sand and granule gravel on the Bad River flood plain in the NW $1 / 4$ sec. 10 , T. 4 N., R. 31 E. before reaching the Pierre shale in the valley floor.

The grain-size range and character of alluvium in tributary valleys is determined by the units that crop out in the drainage area of a given valley. Thus alluvium in valleys southwest of the Missouri River is largely reworked shale. This type of alluvium locally is difficult to distinguish from the weathered shale from which it is derived. Alluvium in valleys northeast of the Missouri River contains Pierre shale detritus and sand and gravel derived from glacial drift. 
Terrace alluvium forms terraces 8 to 20 feet above the present flood plain and is somewhat older than the recent alluvium. The lower parts of the terrace alluvium are inundated only during exceptionally high floods on the Missouri River.

\section{GEOMORPHIC DEVELOPMENT OF THE AREA IN THE PLEISTOCENE EPOCH}

The Pleistocene history of the region west of the Missouri River before the Wisconsin stage is largely one of stream erosion and deposition, controlled at certain times by erents in the glaciated region to the east. Evidence pertaining to events before the Wisconsin stage east of the Missouri River is very scanty, owing partly to erosion and partly to the thick blanket of glacial drift of Wisconsin age. In contrast, the history of the Wisconsin is well recorded by the thick glacial deposits in the Missouri River trench and the area to the east, but is imperfectly known in the region west of the river.

\section{KANSAN AND PRE-KANSAN TIME}

The oldest Pleistocene deposits are remnants of stream alluvium that now cap the highest ridges in the Pierre area. Since the deposition of this high-level alluvium in stream channels, the topography of the region evidently has undergone complete reversalthe lowest parts of the topography of earlier times now form the highest points. Topographic inversion is aided by the fact that the poorly consolidated Pierre shale is readily weathered and eroded. On weathering, the shale breaks down to gumbo which is nearly impermeable and thus allows precipitation to run off and to cut gullies. Sand and gravel deposits, however, allow precipitation to infiltrate because of their high permeability, and can retain a large amount of moisture before runoff occurs. An area capped by gravel thus is less susceptible to erosion and will remain higher than adjacent topography directly underlain by Pierre shale. The parts of former valley floors that originally contained the thickest alluvium now are high areas, and contemporary adjacent upland areas that were not mantled with alluvium are now valleys.

The highest and probably the oldest of these highlevel deposits of alluvium caps Standing Buttes (fig. 20). Although the stream that deposited the alluvium at this locality must have left a band of similar alluvium along its course both east and west of Standing Buttes, this band evidently has been removed by erosion. It is inferred that the Sully Buttes in western Sully County (fig. 20) originated as a high area protected by a sand and gravel capping. If this inference is correct, the protective capping might have been an eastward continuation of the alluvium at Standing Buttes.

The deposit at Standing Buttes is dated only as younger than middle Pliocene and probably older than Yarmouth. The land surface in the Pierre area contemporary with deposition of the alluvium has been destroyed by erosion; thus details of the topography of the region during and prior to the Kansan stage are not known.

Physical evidence of glaciation in the Nebraskan and Kansan stages is lacking. The glaciers of these stages very probably did not extend westward to the Pierre area, for, if they had, there should be some evidence of drainage diversion caused by the advancing ice sheet similar to the diversion caused by the glacier of the Illinoian stage. From the beginning of the Pleistocene epoch until after Kansan time the Pierre area was slowly being lowered by stream erosion and mass wasting. Although downcutting very likely altered with aggradation in the principal eastward-flowing streams, a progessive lowering of stream profiles occurred. Probably during this interval the last remnants of prePleistocene Cenozoic deposits were stripped from the interfluves in the region.

\section{YARMOUTH STAGE}

\section{TOPOGRAPHY AND DRAINAGE}

The gradual erosional lowering of the Pierre area that started at or shortly before the beginning of the Pleistocene epoch continued with only minor interruptions through the Yarmouth into the Illinoian stage. Remnants of once-widespread bands of alluvium deposited during Yarmouth time are preserved in the Oahe quadrangle in three groups, segregated on the basis of their altitude (fig. 12). Similar stream deposits are not preserved on upland areas south of the Bad River. This circumstance might be accounted for by supposing that the deposits once were present but have since been removed by erosion. More probably, however, the stream responsible for the high-level alluvial deposits in the Oahe quadrangle was restricted to a flood plain that lay north of the course of the present Bad River. If this suggestion is correct, this ancestral stream progressively shifted southward after it deposited the alluvium at Willow Creek Butte.

High-level deposits of stream alluvium can be traced from the Oahe quadrangle westward. To the east, however, they are represented in the Pierre quadrangle only by a few patches of pebbles, too thin to represent on the geologic map. Two of these patches are on the crest of Brown Hill, and on a hill in the NW1/4 sec. 22 , T. 5 N., R. 30 E. East of the Missouri River similar highlevel deposits have been removed by erosion or covered 


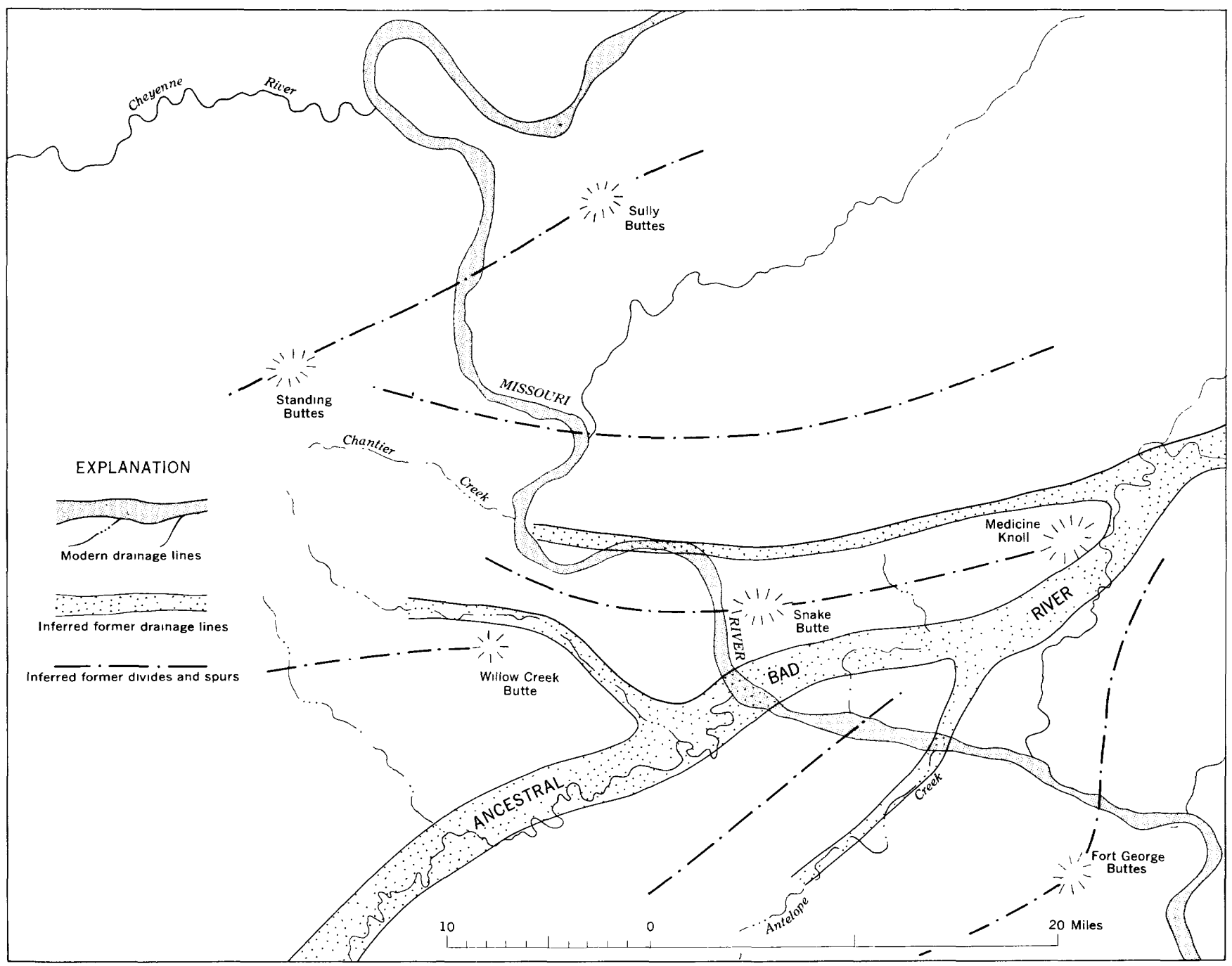

FIGURE 20.-Reconstruction of inferred topography and drainage extant immediately before formation of the Missouri River trench. Reconstruction in Sully County in part after Flint (1955).

by glacial drift, although it seems certain that they once were present.

Because areas underlain by sand and gravel are better suited to survive erosion than are areas underlain directly by shale, it is inferred that high bedrock areas owe their altitude to a once-present cap of stream alluvium; thus Snake Butte in the Pierre quadrangle and Medicine Knoll in the Canning quadrangle are inferred to have originated as high areas because of such a protective cap. Inasmuch as these two high areas are collinear with the eastward-trending bands of alluvium in the Oahe quadrangle, Snake Butte and Medicine Knoll probably represent points on the eastward extension of the stream responsible for the high-level stream deposits of Yarmouth age in the Oahe quadrangle. The divide areas contemporary with the deposition of this alluvium have been entirely destroyed.

\section{ORIGIN OF SOUTHEASTWARD-TRENDING TRIBUTARY} DRAINAGE PATTERN

A conspicuous southeastward-trending pattern of tributary drainage exists in the area southwest of Pierre where the surface is underlain chiefly by the Pierre shale. A similar drainage pattern is absent from the region mantled by glacial drift northeast of the Missouri River. The southeastward-trending drainage pattern is strikingly illustrated by tributaries of Willow Creek in the northwest corner of the Oahe quadrangle, and by tributaries of the Bad River southwest of Fort Pierre.

The strike of the pattern generally ranges from $\mathrm{S}$. $40^{\circ}$ E. to S. $50^{\circ}$ E.; cutting across this trend are the Missouri and Bad Rivers, Antelope Creek, and in the southwest corner of the Pierre quadrangle an unnamed, northward-flowing tributary of the Bad River. In addition, segments of other stream valleys trend across 
the pattern; examples are the valley of Willow Creek in the center of the Oahe quadrangle and the downstream parts of the valleys of Ash Creek and Brokenneck Creek.

\section{HYPOTHESES OF ORIGIN}

DISCUSSION

A drainage pattern showing close parallelism between the axes of adjacent valleys might originate throngh the influence of the regional slope of the land surface, by structural control resulting in differential erosion, and by eolian activity. These hypotheses will be examined briefly to determine their possible application to the problem of the origin of alined tributaries in the Pierre area.

The regional surface slope in central South Dakota is eastward; the Bad River flows parallel to the dip of this slope. Assuming no special circumstances, normal headward growth of tributaries of the Bad River in the Pierre shale should result in a dendritic drainage pattern trending generally to the southwest and northwest. Although tributaries north of the Bad River generally conform to this description, tributaries to the south flow northwestward to a junction with the Bad River; thus they bear a barbed relation to the eastward-flowing Bad River. Therefore the origin of the alined drainage is not related to the direction of the regional slope.

Structural features that cause weak zones in the Pierre shale very likely would exert considerable influence on the headward growth of a tributary system. This influence is demonstrated in the area at several places where a short segment of a gully coincides with the trace of a prominent joint. Such segments rarely are more than a few hundred feet long; the gully deviates from the joint trace for no apparent reason. Segments of gullies that are determined by joints trend, as commonly as not, in directions athwart the overall southeastward trend of the gully. As joints in the Pierre shale typically are limited in extent in the directions of both dip and strike, and as joints in the uppermost three members of the Pierre shale appear to be random in orientation, it is improbable that zones of weakness in the shale attributable to joints are sufficiently extensive to be responsible for influencing gullying for distances of more than a few hundred feet.

In western Ziebach County (fig. 1), Russell (1925, p. 15-16) noted that there is a

marked relation existing between the structure and the topography. There is in this area a striking tendency for valleys to occupy synclines and for the ridges and divides to occupy the anticlines.
In the Pierre area there is no apparent correlation between fold structures observed by the author and the southeastward-trending drainage pattern.

A spatial relation between faults and the trend of gullies has not been observed in the Pierre area. Twenty miles to the north, however, Dr. E. H. Stevens (written communication) found that, in Armstrong County, the orientation of some second-order tributaries was influenced by northward-striking faults, and that in one area the trend of some very small third- and fourthorder tributaries was determined by one group of faults striking northwestward and others by faults striking northeastward.

The Pierre shale exposed in the Pierre area is remarkably uniform in resistance to erosion; steps or benches on slopes that might be indicative of the outcrop of beds of greater resistance to erosive processes do not occur in the uppermost three members of the shale. The apparent lack of long, continuous folds further reduces the possibility that headward growth of tributary streams is guided by dipping layers of resistant rock.

A third way in which parallelism of drainage might originate is through wind action. To explain a southeast orientation of drainage tributary to the North and South Platte Rivers near their confluence in western Nebraska, W. L. Russell (1929) suggested that prevailing northwesterly winds deposited longitudinal sand dunes in the area now occupied by the oriented drainage pattern. Long interdune troughs caused a concentration of runoff and guided the growth of a southeastward-oriented drainage pattern. The pattern, once established, then was preserved during protracted erosion and finally was superposed on underlying bedrock formations.

Another way in which wind action might influence the headward growth of gulleys was suggested by C. L. Baker (1948, p. 5-8).

In Haakon County, (fig. 1) some 50 miles west of Pierre, northwesterly winds have scooped out ovate basins in the Pierre shale. Baker proposed that, in the past, depressions similar to these filled with runoff and overflowed into adjacent basins. By erosion of the nonresistant shale between depressions, a gradual integration of drainage took place. Continued erosion drained the depressions, and the streams cut headward along the long axes of the basins, and thus became oriented in a northwesterly or southeasterly direction.

Baker pointed out that the presence of eolian sediments distributed in ridges would produce the same effect of drainage localization as would water spilling over between adjacent depressions. He favored the latter hypothesis principally because longitudinal dunes 
do not exist on upland surfaces today, whereas closed depressions do occur in large numbers on the upland in Haakon County.

\section{EOLIAN HYPOTHESES OF ORIGIN}

In the absence of adequate evidence supporting a logical alternative explanation, it is inferred that the southeastward-trending drainage pattern in the Pierre area probably is in some way genetically related to the direction of the prevailing winds. At Pierre, U. S. Department of Agriculture climatology records kept over a period of 12 years show strongest winds consistently from the northwest, with secondary strong winds from the southeast. From 1891 to 1930 the prevailing wind direction for June, July, August, and September was southeast; for May, east; and for the remaining months, northwest. 'Thus both the prevailing winds and the strong winds blow from the northwest or the southeast.

\section{Longitudinal dune hypothesis}

The longitudunal-dune hypothesis of the origin of alined drainage in western South Dakota was advanced by Russell (1929) as an extrapolation of his observations in western Nebraska. West of Pierre, possible sources of dune sand exist in the form of alluvial sand and gravel of Pleistocene age. These alluvial deposits once were far more widespread than at present in that they mantled much of the upland area north of the Bad River. Dume sand does not now occur on uplands in the Pierre area. One might argue, however, that the presence of many deflation basins in the area suggests that there has been considerable lowering of the overall upland surface through deflation, during which areas of dune sand could have been completely removed. If sand dunes once existed in the area, they presumably lay on a surface that has now been destroyed by wind erosion, slope wash, and stream erosion.

An alternate source of material for the postulated longitudinal dunes is the Pierre shale itself. The loose, granular soil on the shale is subject to deflation when dry. An interesting statement of the ability of the wind to deflate and deposit this material is recorded by Flint (oral communication from Glenn Avery, U. S. Department of Agriculture, Soil Conservation Service, in Flint, 1955, p. 132 as follows:

During the dry "dust-bowl" years in the 1930 's dunes consisting entirely of flakelike aggregates of clay minerals were piled 10 feet high along fence lines and other obstacles in Tripp County, South Dakota, and during the same years new basins appeared in surfaces underlain by Pierre shale.

Formation of dunes of aggregated clay particles has been recorded by Huffman and Price (1949) from an area near Corpus Christi, Tex., where dumes as high as 30 feet occur through distances of several miles in the lee of tidal flats. Coffey (1909) described the formation of clay dunes near the mouth of the Rio Grande in Texas where the dunes are associated with present or former lagoons, in which periodic drying of clayey materials takes place. The mud cracks, curls, and is then deflated.

If dunes of Pierre shale detritus formed on upland areas, subsequent runoff would have been localized in the interdune troughs and the resulting tributary drainage system would have developed in a southeasterly direction. This hypothesis does not need to account for the subsequent removal of great quantities of windblown material, for, in a following period of greater precipitation, "dunes" or low ridges of winddeposited clay particles soon would merge laterally with the upland surface and become indistinguishable from the ordinary residual mantle developed on the Pierre shale. While such clay-particle dunes have so far not been identified in the Pierre area, it is believed possible that the process of clay-dune formation might well have been in operation at one or more times in the past.

\section{Deflation basin hypothesis}

Large numbers of ovate, closed depressions in the Pierre shale are present on the upland surfaces southwest of the Missouri River. (fig. 21). Most of the depressions have a southeasterly elongation and they are generally twice as long as they are wide. Measurement of 20 depressions indicates that the average size in a southeasterly direction is about 0.28 mile and in a northeasterly direction about 0.14 mile; they range in length from a few tens of feet to 0.8 mile, and in width from a few feet to 0.6 mile. Some large depressions contain several smaller basins. The depth of the basins ranges from less than one foot to about 15 feet.

As the elongation of the closed depressions does not appear to be genetically related to structural or lithologic features of the Pierre shale, it is inferred that the elongation depends on the directions of the prevailing winds. Once a small deflation depression is formed, there is a tendency for that depression to increase in size in a downwind direction simply because deflation is more active on the downwind slope than any other slope of the basin.

The distribution of the depressions appears to be generally random on upland surfaces; some occur singly, others in groups of 2 to 10, and still others in groups of 20 to 60 . The cause of this distribution is not understood. Groups of basins generally have a southeast elongation; this is due, at least in part, to the fact that groups occupy a southeastward-trending divide area. 


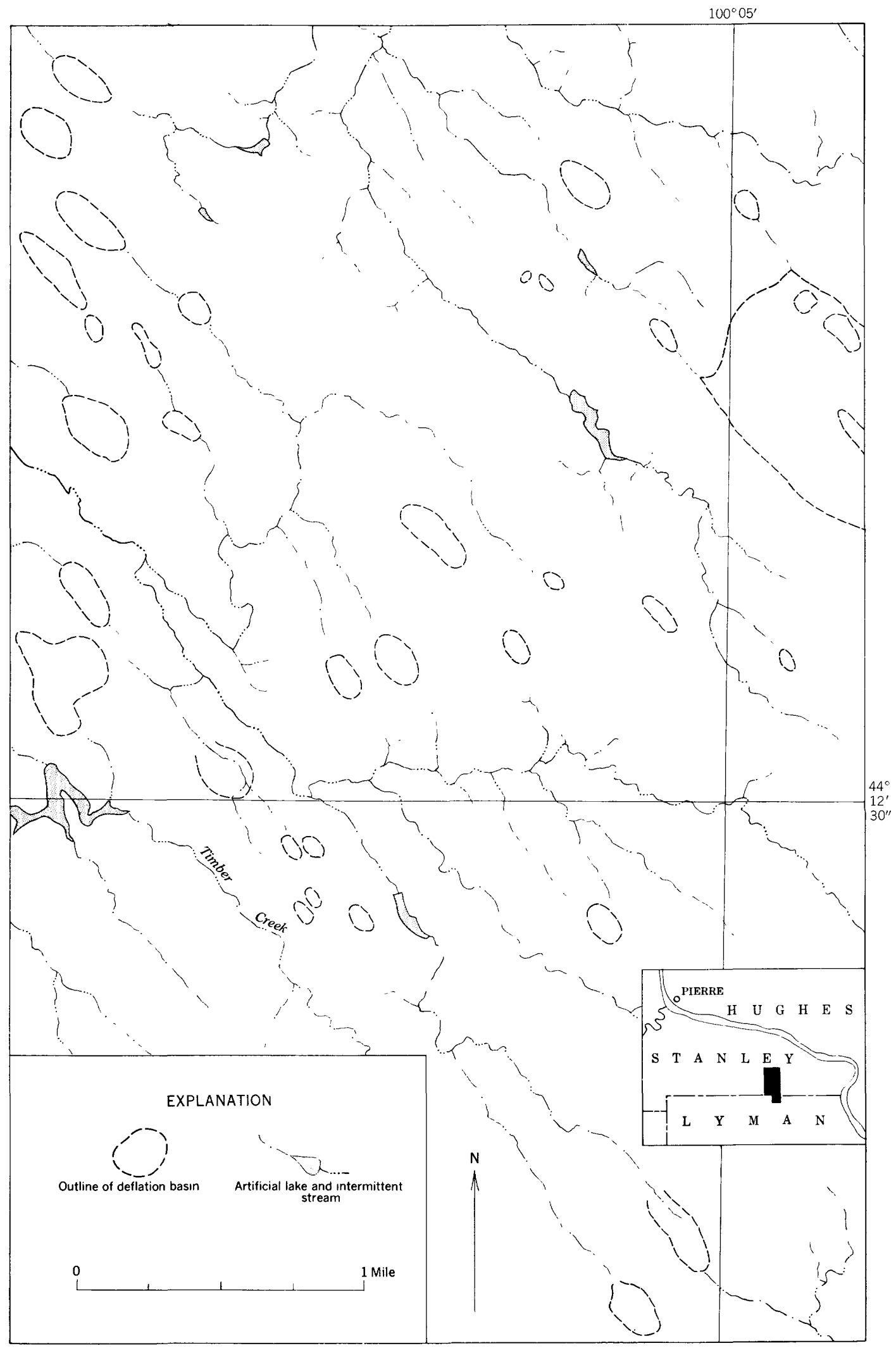

FIGURE 21.-Deflation basins and tributary drainage pattern in an area southeast of Pierre. 
The deflation basins are regarded as more or less temporary landscape features whose presence indicates recent conditions favoring deflation over filling, for the basin, once formed, immediately is subject to filling by alluvium and colluvium moving from the sides toward the deepest parts of the depression. Persistence of the basin depends on the relative efficiency of deflation in comparison to processes tending to fill the basin. Existing depressions were deepened and some undoubtedly were created during the period of desiccation in the 1930's. During the period of this investigation, the trend has been toward filling of the existing basins. Many are swamps or ponds during spring and summer months; the moisture permits a dense growth of regetation that discourages wind erosion even after the standing water has disappeared. The presence of such basins today, regardless of time or origin, indicates that deflation is an important factor in lowering the surface of the Pierre area under favorable conditions of little rainfall, general absence of vegetation, and strong winds.

Orate deflation basins have considerable influence on the growth of gullies in a southeasterly or northwesterly direction. Gullies eroding headward into nearly flat upland surfaces locally intersect elongate basins; the course of the tributary then is extended along the long axis of the depression. Incipient stages of this process, as well as examples of actual intersection of basins by gullies, can be seen in figure 21 . In a few places, examples of drainage integration, apparently caused by water spilling between adjacent depressions, can be observed.

Once a basin has been intersected by a stream, dissolution of the original depression is rapid because of increased rates of slope wash and mass-wasting processes owing to steeper slopes. Thus, outlines of old basins that guided the development of gullies at an earlier time generally are not apparent along the downstream segments.

It is very likely that at one or more times in the past, the Pierre area has had at least as little precipitation as during the "dust-bowl" days. During the dry periods, deflation basins and groups of basins (and possibly clay-particle dunes) would have been created when wind erosion was dominant. The stage would then have been set for a following more moist period during which streams were the dominant erosive process. The basins then were cut into and incorporated into the southeastward-trending drainage pattern.

With the exception of the Missouri River trench, the stream valleys and segments of valleys that cut across the alined drainage pattern are thought to be parts of a drainage system that predates the origin of the alined drainage. Prior to the initial cutting of the Missouri River tremch the ancestral Bad River was flowing across the Pierre area on a profile several hundred feet higher than the present flood plain. Ancestors of Willow Creek and Antelope Creek were tributary to this master stream. Willow Creek now flows across most of the Oahe quadrangle in an easterly direction; 2 miles from the east edge of the quadrangle, however, the valley turns and trends southeast, parallel to the other tributaries of the Bad River. The valley south of this bend is somewhat narrower and steeper-sided than the eastward-trending segment upstream from that point. There is no topographic evidence of a former eastward continuation of Willow Creek beyond the place at which it now turns to the southeast. These facts imply that the eastward-trending segment was formed before the development of the adjacent southeastward-trending tributaries of the Bad River, and that the upstream part of the valley is older than the downstream segment. This implication requires some manner of "ending" for the older, eastward-trending part of the valley of Willow Creek. Willow Creek may originally have had a confluence with the high-level ancestral Bad River at the place where the valley turns sontheastward. The segment of the valley downstream from this place then was formed when the ancestral Bad River cut down and planed laterally southward toward its present location.

\section{TIME OF ORIGIN}

A key point in the plyysiographic evolution of the Pierre area in the Pleistocene epoch was the time of the initial cutting of the Missouri River trench. Because the trench predates glacial drift of Iowan age and postdates alluvium of probable Yarmouth age the trench is inferred to have originated at the maximum of the Illinoian age.

Tributary valleys of the Bad River are much longer than the southeastward-trending tributaries of the Missouri River. This fact implies that the Missouri River trench was cut after the initial development of the alined drainage pattern. Because alinement does exist in tributaries of the Missouri River, however, conditions leading to alinement must have continued after the Missouri River trench was formed.

Broad, gently sloping surfaces on the upland adjacent to each of the southward-trending tributaries of the Bad River occur in the Oahe quadangle and in the western part of the Pierre quadrangle. These surfaces are southeastward-trending depressions in the centers of which are the present steep-sided valleys tributary to the Bad River. The broad depressions are inferred to be broad valleys graded to the Bad River when it was flowing on a profile several hundred feet higher 
than at present. Because these broad valleys are oriented southeast, their formation must postdate conditions that caused drainage alinement. Yet these broad valleys postdate the stream alluvium of probable Yarmouth age at the Stroup locality because they are topographically below this alluvium. Therefore, the broad valleys probably were formed during a gradual lowering of the area in Yarmouth and early Illinoian time, although it is conceivable that the orientation of the broad valleys was inherited from an even higher, older surface. The lowering base level that accompanied formation of the Missouri River trench in the Illinoian stage caused intrenchment of the broad valleys and the development of the present steep-sided tributaries.

In summary, the above inferences in regard to the time of origin of the alined drainage pattern indicate that conditions favoring development of the pattern were first set up in late Kansan or early Yarmouth time. Since that time these conditions probably have been repeated many times, and the extension of present tributaries along the long axes of deflation basins shows that drainage today is continuing to be guided in a southeast direction.

The presence of gullies eroding headward along the axes of ovate deflation basins indicates that eolian processes are responsible at least in considerable part, for the development of an alined drainage pattern in the Pierre area. The absence of longitudinal sand and (or) clay-particle dunes today suggests that these features are not necessary to the growth of the pattern, but this absence does not necessarily imply that longitudinal dunes have not influenced drainage at some time in the past.

The inception of alined drainage appears to date from middle Pleistocene time; the growth of the pattern has continued, although perhaps intermittently depending on climatic conditions, from that time to the present.

Although the conclusions reached here are strictly pertinent to the Pierre area only, the deflation-basin hypothesis of the origin of alined drainage has wide application in western South Dakota. It is not proposed, however, that this hypothesis has equal validity wherever alined drainage exists, for in some areas in the northern Great Plains there is compelling evidence for both the longitudinal-dune origin and a structuralcontrol origin of a drainage pattern of alined tributaries.

\section{ILLINOIAN STAGE}

The Illinoian stage marked a drastic rearrangement of drainage in the Pierre area, owing to the advance of a continental glacier from the east or northeast.
Early in the stage, however, topography and drainage lines were essentially as they had been during the preceding stage.

\section{DIVIDE AREAS AND DRAINAGE PATTERN BEFORE GLACration}

The major divides of the region that exist today appear to have been present in Illinoian time. These divides are inferred to have originated through a protective capping of stream sediments of western derivation.

The northern divide of the ancestral Bad River drainage basin was a high area about 5 miles north of the northern edge of the Oahe quadrangle. Today the lighest part of this divide is at Standing Buttes. East of the Missouri River, Sully Buttes in western Sully County probably represents a point on the former interfluve that separated the eastward extensions of the Bad and Cheyenne drainage basins (fig. 20). Flint (1949b, p. 67) suggested that this interfluve, which he termed the Redfield divide, once formed part of the continental divide, separating the drainage of the Hudson Bay region from that of the Gulf of Mexico.

A prominent divide in the Pierre area is the high groumd between the Bad River and Chantier Creek; Willow Creek Butte is a high knob on this divide in the Oahe quadrangle. Prior to Illinoian glaciation, this divide continued with minor interruptions eastward from Willow Creek Butte across Giddings Flat to Snake Butte, Body Ranch hill, and Medicine Knoll.

The southern edge of the Bad River basin is marked by high ground in northwestern Lyman County about 18 miles south of Pierre, where the divide reaches an altitude of about 2,220 feet. From that area the divide trends northeastward and joins the Fort George Buttes, a group of hills underlain by the Mobridge member of the Pierre shale, in southeastern Stanley County (fig. 20). Flint (1955) suggested that before the Missouri River trench was cut, this divide trended northeastward from the Fort George Buttes, across the present Missouri near DeGrey in southeastern Hughes County, and extended northeastward to the Ree Hills, a highland in south-central Hand County (fig. 1). A northward-trending spur branched from the Fort George Buttes to a ridge along the east margin of the Canning quadrangle.

Early in the Illinoian stage the ancestral Bad River crossed the course of the present Missouri and continued eastward through Hughes County. Todd (1914) suggested that this ancestral Bad River either joined an eastward extension of the former Cheyenne River near the mouth of Okobojo Creek in southwestern Sully County (fig. 1), or followed the present course of the 
Missouri downstream from Pierre, then turned northward and followed the course of Medicine Creek to a junction with the Cheyenne in eastern Sully County.

It seems unlikely that the course of the ancestral Bad River in the Illinoian stage was coincident with any segment of the present Missouri River trench. The reasons for this inference are :

1. The uplands adjacent to the Bad River in the Oahe and Pierre quadrangles are graded to a former highlevel valley whose axis coincides with the axis of the present Bad River trench. The uplands adjacent to the Missouri River upstream or downstream from Pierre, however, are not graded to a valley which would coincide with the present Missouri River trench. On the contrary, at most places the upland slopes away from, rather than toward, the trench.

2. The southeastward trend of the Missouri River trench downstream from Pierre forms an angle of about $60^{\circ}$ with the northeastward trend of the present $\mathrm{Bad}$ River. From Midland, in southeastern Haakon County, to Pierre, a distance of nearly 50 miles, the Bad River trench has a northeastward trend. If the ancestral Bad River occupied the segment of the present Missouri downstream from Pierre and up the trench of Medicine Creek, it would have formed two wide deviations in trend in 15 miles, a feature not duplicated elsewhere in the present Bad River trench.

3. From the eastern end of Snake Butte toward the southeast, a smoothly sloping surface grades into a sag that coincides with the eastward-trending segment of Dry Run in the Camning quadrangle. The south wall of this sag lies between Dry Run and a hill in secs. 33 and 34 , T. 111 N., R. 78 W. The axis of this broad depression continues eastward and joins the valley of Medicine Creek in the vicinity of Hiddenwood Gulch and Brekke Draw. This broad topographic sag is underlain by a similar depression in the bedrock surface: Pierre shale in Snake Butte occurs up to an altitude of more than 1,800 feet, shale crops out to an altitude of nearly 1,800 feet in secs. 33 and 34 south of Dry Run, and the shale-glacial drift contact in the axis of the depression at the southwest corner of sec. $27, \mathrm{~T} .111 \mathrm{~N}$., R. $78 \mathrm{~W}$. is at least as low as 1,600 feet. Although the maximum depth of this broad depression probably resulted from erosion during the Sangamon stage, its length and width suggest that the sag coincides with the valley of an ancient major stream; because the sag is collinear with the trench of the present Bad River, it is inferred that the ancestral Bad River occupied it.

The valley floor altitude of the ancestral Bad River just before the advance of the glacier of the Illinoian stage is not known with certainty. This lack of knowledge is due primarily to the absence of any deposits of unquestioned Illinoian age in the area. It might be predicted that as the glacier of the Illinoian stage advanced westward up the valley of the ancestral Bad River, aggradation would have resulted in an alluvial fill west of the ice margin. The high-level remnants of sand and gravel of western origin in the Oahe quadrangle are, almost without exception, veneers of alluvium left on bedrock straths cut by lateral plantation; they represent, therefore, graded streams. In the $\mathrm{SW} 1 / 4$ sec. 25 and the SE $1 / 4$ sec. 26 , T. 4 N., R. 29 E., however, a deposit of nonglacial stream alluvium crops out at an altitude of 1,780 to 1,840 feet. This deposit extends a short distance up tributary valleys and rests on sloping bedrock surfaces rather than on flat, stream-cut straths; therefore the alluvium appears to have originated as a fill in the Bad River valley. The deposit is about 80 feet higher than the fill of Iowan age in the Bad River trench, and therefore probably antedates that fill. The altitude of 1,780 feet might therefore represent a point on a valley side or floor of the ancestral Bad River at the maximum of the Illinoian glacial stage.

If the ancestral Bad River crossed the Missouri at Pierre and continued in an east ward course, the altitude of the contact between the shale and glacial drift at and east of Pierre also should provide a minimum elevation for the former Bad River strath. This contact ranges in altitude from 1,660 to 1,700 feet.

There seem to have been three fair-sized tributaries to the ancestral Bad River; one was Willow Creek; another possibly started near Chantier Creek, trended eastward through Peoria Bottom, and continued eastward from the present bend of the Missouri River trench at Wood Island. From Snake Butte northward to Stony Hill there is a topographic sag and an even more prominent depression in the bedrock surface. The altitude of the ancestral Bad River probably was 1,750 feet or higher; thus a major part of the depression on the bedrock surface must represent post-Illinoian erosion. Nevertheless, the upper slopes of the sag above an altitude of 1,750 feet are thought to represent the sides of a former eastward-trending stream valley collinear with the Peoria Bottom segment of the Missouri River, and tributary to the ancestral Bad River. End moraines east and northeast of Snake Butte have buried a possible former eastward continuation of this broad sag; it seems probable, however, that this tributary trended eastward north of and parallel with the divide from Snake Butte to Medicine Knoll. This course is consistent with the known and inferred system of divides in the area before formation of the Missouri River trench.

The headwaters of a second tributary of the ancestral Bad River coincided with the present valley of Ante- 
lope Creek. Rather than terminating at the Missouri River as does Antelope Creek today, this tributary continued northeastward to a junction with the ancestral Bad River north of Mosteller Draw.

\section{ORIGIN OF THE MISSOURI RIVER TRENCH}

The Missouri River trench is by far the most impressive topographic feature in the Pierre area. Because of its youthful aspect and anomalous course, in which it abruptly truncates five large eastward-flowing rivers in South Dakota, the origin of this feature has been the subject of speculation and hypothesis for more than 80 years. The most recent discussions of the origin of the trench are by Flint $(1949 \mathrm{~b} ; 1955)$ and Warren (1952).

The Missouri River trench has several anomalous relationships to landforms of the region through which it cuts. These anomalies, described below, indicate that a major drainage readjustment took place when the trench was formed.

1. The pattern of drainage west of the Missouri River is conspicuously different from the pattern east of the river. Five large eastward-flowing streams enter the Missouri in South Dakota (fig. 1); each has a large number of tributaries. East of the Missouri River the drainage in the region is poorly integrated; tributaries are fewer in number and most are shorter. Thus, the general drainage pattern in the State is lopsided.

2. The regional slope of South Dakota is eastward. The Missouri River trench trends southerly, nearly at a right angle to the regional slope.

3. At many places east of the Missouri there are distinct topographic sags in the upland surface. The trend of these linear depressions is generally east, and in some places the depressions are collinear with one of the five major rivers west of the Missouri. That these sags are downstream segments of the former eastward-trending stream valleys, abandoned after the creation of the Missouri trench, was suggested by Todd (1914) and confirmed by Flint (1949b).

t. The Missouri River trench, in several places, cuts through eastward-trending divides rather than following a course around their ends. An example in the Pierre area is the position of the trench in relation to Snake Butte. The abrupt westward termination of the butte and the high area west of the river surmounted by Brown Hill seem to indicate that the butte formerly had a greater westward extent. The Missouri River trench is thus cross axial in respect to the inferred original butte. This relationship indicates that the trench did not originate through normal stream development.

3. At many places in the State, upland surfaces immediately adjacent to the trench slope away from the
Missouri River. It is inferred from this that these parts of the upland were formed adjacent to a stream system other than the system graded to the present Missouri River.

The general mechanism of trench formation in South Dakota is based on Flint (1949b) and on oral discussions with Flint.

The westward advance of an ice sheet into central South Dakota from the east or northeast caused progressively deeper ponding in each of the main eastwardtrending valleys, as both drainage from the west and melt water from the glacier were dammed behind the ice barrier. When the water of a lake so formed rose to the altitude of the lowest-divide between that lake and an adjacent drainage basin, the lake drained through that outlet and established a channel in the easily eroded Pierre shale. In some localities the lowest escape route for drainage was along the margin of the ice. By the time the ice margin had retreated to the northeast, a system of connecting drainage channel segments had been formed that was competent to carry both melt water and drainage from the west from that time on. The former eastward extensions of the major river valleys were filled with glacial drift and left in a hang. ing relationship to the newly formed Missouri River trench.

Some segments of the Missouri River trench occupy parts of preexisting main stream valleys and of former major tributaries. A map compiled by Flint (1949b) indicates that the Missouri River trench is coincident with the trench of the ancestral Cheyenne River from the present mouth of the Cheyenne northeastward to the mouth of the Little Cheyenne Creek in western Potter County. The segment of the Missouri trench from the mouth of Chantier Creek in the northeastern part of the Oahe quadrangle downstream to Wood Island coincides with the course of an inferred former eastward-flowing tributary of the ancestral Bad River.

The rearrangement of drainage in South Dakota during which the Missouri River trench was formed was thought to have occurred in the Nebraskan stage by Leverett (1932, p. 19). Flint (1949b) considered it likely that the trench was formed during the Kansan stage, an opinion based chiefly on the tentative identification of till of Kansan age within the trench and on the lack of drift of known Illinoian age in South Dakota. He suggested further that the trench may not be all of the same age, in that the northern part may have been formed by Nebraskan ice and the southern part by Kansan ice. He (1955) subsequently adopted an Illinoian date for the origin of the trench in consequence of Warren's (1952) investigations near Chamberlain, S. Dak. The evolution of drainage as deter- 
mined by Warren in the region near the mouth of White River, 8 miles south of Chamberlain, is summarized below.

The hanging and drift-filled valley of the ancestral White River is exposed in cross section in the east wall of the Missouri River trench, 5 miles northeast of the present confluence of the White and Missouri Rivers (fig. 1). The oldest Pleistocene sediment in the immediate vicinity is a high-level deposit of White River alluvium that forms a knob at an altitude of 1,857 feet. This deposit is dated by included vertebrate fossils as of late Kansan age or younger. During the Yarmouth stage, the White River planed laterally and cut down to an altitude of about 1,450 feet. This latter profile is recorded by the shale floor of the White River valley buried by glacial drift but exposed in cross section in the east wall of the Missouri River trench. As the glacier of the Illinoian stage advanced westward up the White River valley, the ice dam caused the aggradation of an alluvial fill that now overlies the bedrock valley floor. Further advance of the glacier left a thick deposit of till over the alluvial fill and caused the diversion of the White River. The event is dated as being younger than the Kansan stage because of the vertical difference in elevation between the 1,450foot strath and the high-level deposit of the ancestral White River that contains fossils of late Kansan or post-Kansan age. The need for an interglacial interval (Sangamon stage) during which deepening and widening of the Missouri River trench could have taken place is one of Warren's chief arguments that the diversion occurred during the Illinoian stage rather than during the $W$ isconsin stage.

The age of the Missouri River trench in the Pierre area is not known with certainty, but the evidence agrees with the Illinoian date of origin of the trench near Chamberlain.

The youngest dated deposit that antedates the Missouri River trench in the Pierre area is the high-level post-Kansan alluvium at the Stroup locality. Surfaces topographically below this alluvium, and so postdating it, are on the upland west of the Missouri River and possibly east of the Missouri also. The most conspicuous remnant of this surface is Giddings Flat. These surfaces are graded to a former stream valley that intersects and continues across the trench of the present Missouri, indicating that the surfaces were formed before the Missouri River originated. There are no such surfaces graded to the Missouri trench. These surfaces also show that after deposition of the alluvium at the Stroup locality, the ancestral Bad River cut down at least 200 feet, and smoothly graded upland surfaces were formed adjacent to the river. Thus the
Missouri River trench was created after an interval of erosion that followed deposition of the alluvium at the Stroup locality. The oldest known deposit that lies within the Missouri River trench near Pierre, and so postdates initial cutting of the trench, is till tentatively assigned to the Iowan substage.

If the ages of the youngest deposit previous to formation of the trench and the oldest deposit after the formation of the trench are accepted, the trench must have originated during the Illinoian stage. The possibility remains, however, that the trench was not formed in its present position until the Towan substage. If it is assumed that the trench formed by spilling of ponded melt water and drainage frorn the west during an early advance of the Iowan glacier, then conceivably the trench could have been widened and deepened to a depth of about 1,500 feet. A subsequent readrance of the glacier then could have deposited till and outwash sand and gravel within the trench. Although it is granted that this sequence of events can not be disproven by the evidence now at hand, it is considered much less likely than the sequence of the trench having been cut in the Illinoian stage, widened and deepened in the Sangamon stage, and occupied by ice in the Iowan substage.

\section{SANGAMON STAGE}

The Sangamon stage was characterized by downcutting in the Pierre area owing to a lower base level created by the cutting of the Missouri River trench in the Illinoian stage. In the Sangamon the trench probably attained nearly its present width and perhaps also nearly its present depth. The lack of distinct weathering profiles on drift sheets of Iowan age elsewhere in South Dakota (Flint, 1955) indicates that the Iowan-Tazewell interval was a relatively inconspicuous event, probably of insufficient duration to accomplish the pre-Tazewell widening of the Missouri River trench. It seems likely, therefore, that most of the widening and deepening of the trench occurred in pre-Wisconsin time.

Logs of drill holes in the area north of Snake Butte reveal an extensive depression in the bedrock surface, whose altitude is from 200 to 300 feet lower than the inferred Illinoian surface of the area. This difference in altitude indicates that the depression was graded to some stream system other than that of the ancestral Bad River, and the only topographic feature low enough to have accommodated drainage from this depression is the Missouri River trench. It is believed that the depression drained into the trench just south of the test-pit exposure, where the lowest known altitude of the contact of the shale and Iowan till in the east trench wall is about 1,5020 fect. Because till of inferred Iowan age lies in the lowest part of this depression in the east 
trench wall, the depression probably was excavated during the Sangamon stage.

During the Sangamon stage a segment of the abandoned course of the ancestral Bad River east of Pierre was dissected. The broad topographic depression coincident with Dry Run (p. 51) in the western part of the Canning quadrangle is underlain by a similar depression in the bedrock surface that is at least 100 feet lower than the inferred altitude (about 1,700 feet) of the ancestral Bad River east of Pierre. Although drift of Iowan age is not known to lie within this depression, it is likely that the depression was cut during the Sangamon stage.

Both areas of deep pre-Wisconsin dissection are coincident with, although much lower than, inferred valleys that were in existence before formation of the Missouri River trench. These valleys possibly were not entirely filled with drift at the maximum of the Illinoian stage, but remained as distinct topographic depressions that localized runoff and erosion as soon as the ice front retreated.

\section{WISCONSIN STAGE}

The western edge of a lobe of the continental ice sheet (fig. 14) covered all or part of the Pierre area during the Iowan, Tazewell, and Cary substages. The physiographic evolution of the region thus consists largely of drift deposition during the glacial periods and drift dissection following the glacial maxima. The general effect of the blanket of glacial drift northeast of the Missouri River has been to smooth surface irregularities made by stream erosion and mass wasting during the Illinoian and Sangamon stages.

\section{IOWAN SUBSTAGF}

Much of the area northeast of the Missouri River is underlain by 100 to 200 feet of glacial drift of the Iowan and Tazewell substages. This glacial drift postdates a period of extensive dissection, which is inferred to have occurred principally during the Sangamon stage and which lowered parts of the area by several hundred feet.
Before the Iowan glacier covered the Pierre area, the floor of the Missouri River trench probably was at an altitude of about 1,500 feet; each of the other present principal drainage elements of the area, such as Medicine Creek, Antelope Creek, and the Bad River, was in existence. In addition to these features there was a sizeable valley north of Snake Butte that drained into the Missouri River opposite the downstream end of Wood Island. Another valley, coincident with a segment of the abandoned channel of the ancestral Bad River, had developed in the vicinity of the eastwardtrending segments of Dry Run and Mush Creek in the Canning quadrangle. Prior to the Iowan glaciation, this valley might have extended uninterruptedly from the vicinity of White Palace in the Canning quadrangle westward to the east edge of the Pierre quadrangle. This inferred valley now is blocked by an end moraine of Tazewell age.

The advance of the Iowan glacier probably largely obliterated the tributary drainage system that had become established northeast of the Missouri River during Sangamon time. Southwest of the river, however, the glacier contained little debris, probably was not very thick, and presumably melted back rapidly from its greatest westward extent, thus modifications of the upland surface by the glacier are not apparent. Before ponded melt water in the eastward-flowing tributaries of the Missouri overflowed and cut spillways through interfluves, the ice margin retreated and uncovered an escape route: the Missouri River trench. By the time the ice margin lay along a line extending approximately from Willow Creek Butte to Snake Butte, melt water had built a proglacial valley train in the Missouri River trench up to an altitude of about 1,700 feet (fig. 22). Melt water from the glacier margin on the upland west of the trench flowed down tributary valieys of the Bad River and left veneers of outwash gravel on straths cut into Pierre shale. This melt water, added to runoff from the drainage basin of the Bad River, built an alluvial and outwash valley fill in the Bad River trench that was graded to the valley train in the trench

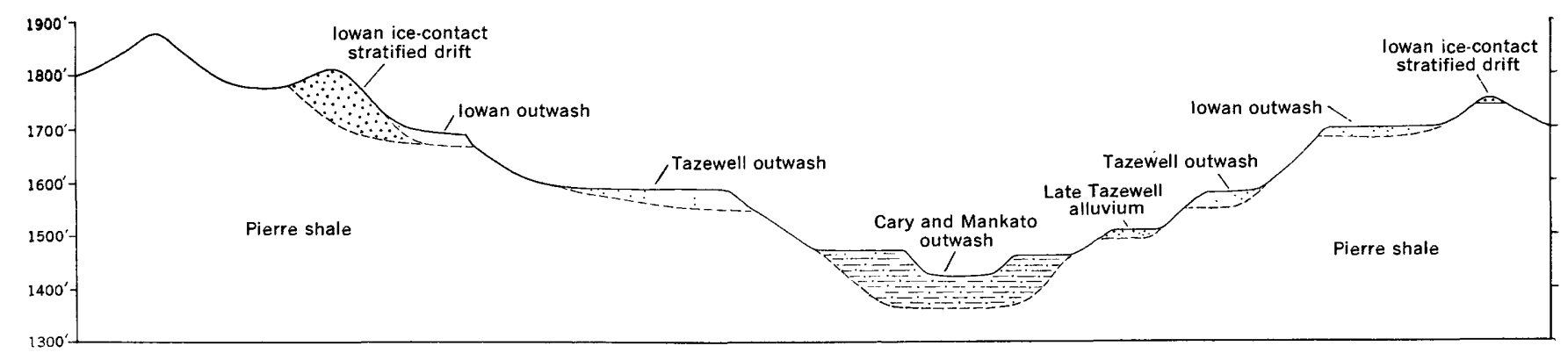

FIGTiE 22.-Diagrammatic cross section of the Missouri River trench in the Pierre area showing the inferred sequence and vertical distribution of stratified drift of the Wisconsin substages. 
of the Missouri. After further northeastward retreat of the ice margin, stratified drift was deposited adjacent to stagnant ice along the north wall of Peoria Bottom and on the southwest wall of the Missouri River trench opposite Wood Island.

The deglaciation of the Pierre area during the Iowan substage cannot be reconstructed further because deposits of Iowan age northeast of the Missouri River are covered with Tazewell and Cary drift.

\section{IOWAN-TAZEWELL INTERVAL}

Downcutting in the Missouri River trench, amounting to about 150 feet, appears to be the only recorded event during the interval between the maxima of the Iowan and Tazewell substages. This intrenchment in unconsolidated material is not a convincing record of an appreciable time lapse, nor is it known that most of the intrenchment occurred in the interglacial interval rather than late in the Iowan substage. This lowering of the Missouri River channel must have caused concomitant intrenchment of all tributary streams. The extent of widening and deepening of the tributary valleys at this time is not known, but in view of the overall insignificance of the Iowan-Tazewell interval elsewhere in South Dakota (Flint, 1955), probably intrenchment was not appreciable.

Inasmuch as stratified drift of Iowan age is the youngest known Pleistocene deposit in the Pierre area southwest of the Missouri River, subsequent stages in the development of landforms can not be dated in that area; indeed, there is little evidence to suggest any notable change of conditions in that area from Iowan time to the present. Instead there appears to have been an uninteriupted reduction of the surface through stream and wind erosion and mass-wasting processes.

\section{TAZEWELL SUBSTAGE}

During the Tazewell substage a lobe of the continental ice sheet again reached the Pierre area. At the maximum of the substage, the glacier reached the Missouri River trench, but evidently did not extend southwestward beyond the trench as did the Iowan glacier. The distribution of Tazewell till, the presence in the trench of a concentration of boulders that is inferred to represent a lateral continuation of an end moraine, and locally very coarse Tazewell outwash indicate that the glacier front was irregular in the Pierre area, locally reaching and probably largely filling the trench, elsewhere failing to reach the trench by a mile or more.

Soon after reaching the Missouri River trench north of Pierre, the glacier melted back a short distance to the east and built the Pierre and Body Ranch end moraines. Whether this moraine building was due to temporary halts during a general recession of the ice margin, or to reexpansions of the glacier is not known. The predominance of till in both moraines and a notable lack of associated stratified drift in the form of an outwash plain, eskers, and kames on the upland northeast of Pierre suggest that the glacier in the Pierre area was characterized by vigorous flowage, even during deglaciation (see Flint, 1947, p. 129).

While the end moraines were being built northeast of Pierre, the ice margin east of Pierre probably was still in or closely adjacent to the Missouri River trench. While the products of continued ice flowage were piling up in one sector of the ice margin as end moraine, in the sector adjacent to the trench these products were being continually carried away by melt water. There is nothing to indicate that the trench was completely blocked by ice at any time during the maximum of the Tazewell substage.

At a time when the ice margin was in or very near the trench (fig. 23), a proglacial and in part icemarginal outwash valley train started to accumulate. Subsequently, when the ice terminus was at the Body Ranch end moraine, melt water coming from the glacier evidently drained through the valleys of Spring Creek, which flowed northwestward to join the Missouri River trench a short distance northwest of the Pierre quadrangle, and Dry Run, which flowed southwest and entered the Missouri at the east edge of the Pierre quadrangle. The outwash train in each valley was graded to the surface of the Tazewell valley train in the Missouri River trench. After the ice terminus retreated eastward and exposed the valley of Medicine Creek, this valley also formed a route for melt water to the Missouri River trench. The outwash deposits in the valley of Medicine Creek were graded to the large terrace north of Rousseau. This terrace is 20 or 30 feet higher than the Tazewell outwash terrace on the opposite side of the Missouri River trench, so it seems likely that local aggradation occurred in the Missouri at the mouth of Medicine Creek owing to the sand and gravel being contributed by that stream.

The notable absence of outwash associated with the Tazewell end moraines in the Pierre area indicates that a large proportion of the total debris carried in the glacier is now lodged in the moraines, and that probably a very small proportion was removed by melt water when the ice terminus was in the vicinity of the moraines. This reasoning, in addition to the fact that the Tazewell outwash valley fill contains large boulders that probably were not transported far from where ther were dropped by the glacier, suggests that the valley train in the Missouri accumulated almost wholly 
GEOLOGY OF THE PIERRE AREA, SOUTH DAKOTA

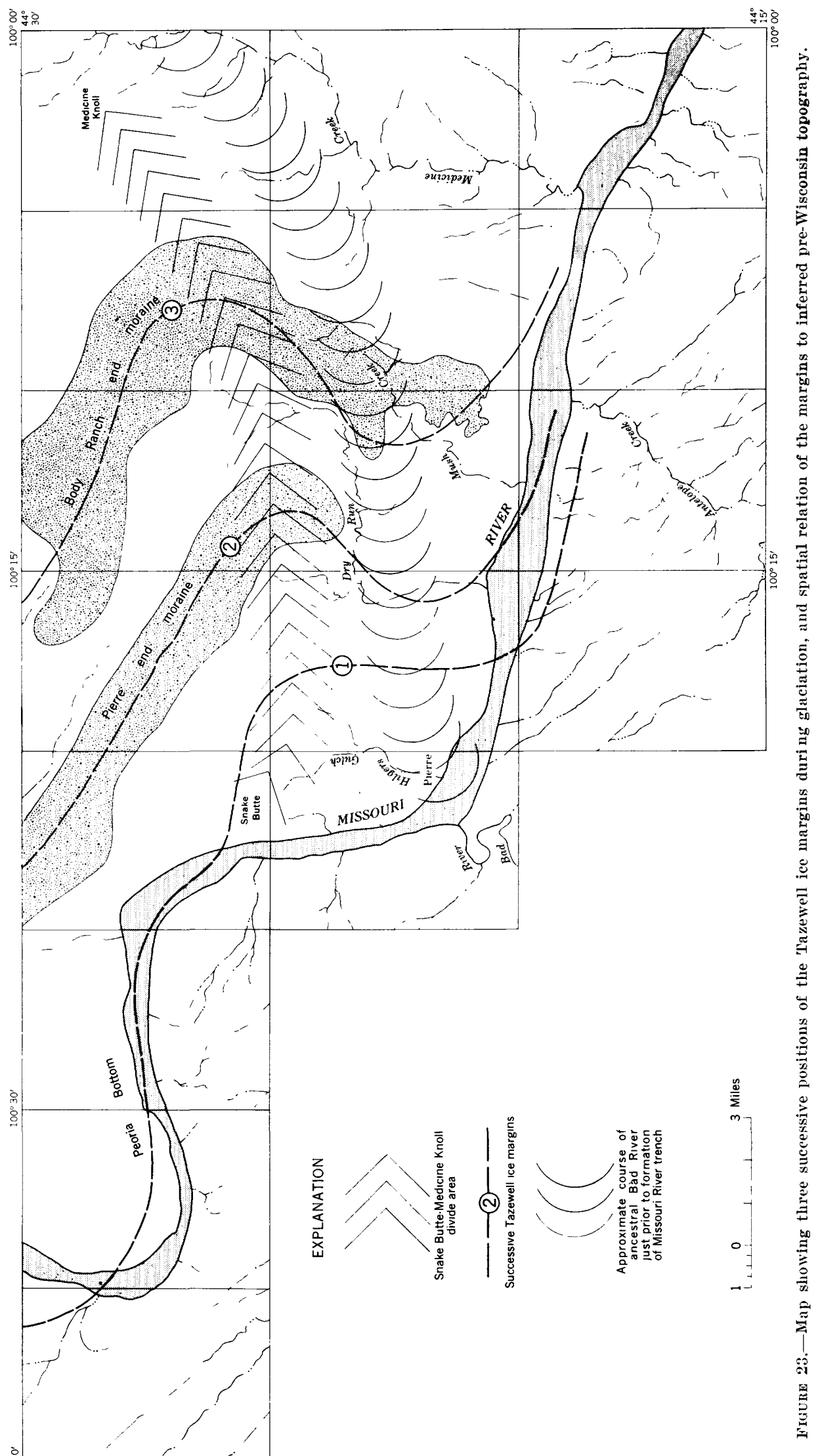


at a time when the Tazewell ice margin was in or closely adjacent to the Missouri River trench at the maximum of the Tazewell substage.

The time of dissection of the valley fill is suggested by the terrace deposit on which the State Capitol Building is situated at Pierre (p. 34). This deposit is younger than the Tazewell valley train, but is inferred to be older than the Tazewell-Cary interval because the terrace is overlain by loess deposits containing two soil profiles, one assigned to that interval. Thus it is reasoned that dissection of the Tazewell valley train probably started late in the Tazewell substage, perhaps even while the Tazewell glacier was not many miles east of the Pierre area.

The aggradation of the Tazewell outwash thus is explained as a response to the outwash load contributed to the Missouri River trench at the maximum of the Tazewell substage: the gradient of the trench floor was increased so that the additional load could be transported. With recession of the glacier to the northeast, the load was reduced and the Missouri River started to trench the outwash deposits. Whether the Missouri River attained a graded condition before the TazewellCary interval is not known.

The configuration of the inferred ice margins of the Tazewell glacier probably is related in origin to the topography of the area prior to the Tazewell substage. A major relief feature of the Pierre area before the Illinoian stage (p. 50) was a ridge that trended eastward with minor interruptions, from Willow Creek Butte in the Oahe quadrangle to Snake Butte and Medicine Knoll in the Pierre and Camning quadrangles. Although this divide was breached when the Missouri River trench was created, segments of it exist even now. Erosion in the Sangamon stage probably accentuated the height of the ridge above the flanking lowlands, but this intensification of relief was partly erased by deposition of glacial drift in the Iowan substage. When the Tazewell glacier entered the area elements of the pre-Wisconsin surface, although low, evidently still were sufficiently distinct to influence the glacier. During the maximum advance of the glacier, the divide area had only a slight effect on the ice, as shown by the shallow reentrant in the ice margin (marked " 1 " in fig. 23) northeast of Pierre. During the first readvance of the ice, or during the first halt during a general recession, the ridge from Snake Butte to Medicine Knoll had a greater effect on the ice front (marked " 2 "), as shown by a deeper reentrant. The maximum effect of the ridge is shown by the final ice margin (marked "3") which is represented by the doubly arcuate plan of the Body Ranch end moraine. The small westward lobe of the ice margins directly east of Pierre is coincident with a bedrock low area which originally was located along the axis of the ancestral Bad River and subsequently was the locus of erosion during the Sangamon.

\section{TAZEWELL-CARY INTERVAL}

Field investigations in other areas 11 South Dakota and adjacent states indicate that the time break between the Tazewell and Cary substages was the most significant of the intervals between the Wisconsin glacial substages. In the absence of more certain dating of specific Pleistocene deposits in the Pierre area, little corroborative evidence has been found.

A qualitative examination of the surfaces of the Tazewell end moraines in western Hughes County and the Cary end moraines in the eastern part of the county reveals a morphologic difference that very likely is a function of the length of time the two drift sheets have been exposed to stream erosion and mass wasting. The Tazewell end moraines in the Pierre and Canning quadrangles have a fairly well integrated drainage pattern and there are few closed depressions. In contrast, the surface of the Cary drift in eastern Hughes County is poorly drained and contains many closed depressions. Flint (1955) states that the morphologic differences are characteristic of the surfaces of the Cary and Tazewell drift sheets in other parts of South Dakota. He also mentioned that the topographic expressions of the Tazewell and Iowan drift sheets are closely similar and that the topographic differences between the Cary and Mankato drift sheets also are slight.

If Cary stratified drift underlies the surface of the present Missouri River flood plain (p. 36-37) a question is raised as to the time of cutting of the bedrock floor of the trench. At the time the Tazewell outwash train was deposited, the Missouri River trench was nearly $21 / 2$ miles wide. At the site of the Oahe Dam, the maximum width of the bedrock-floored trench beneath the surface of the present flood plain is about a mile. Dissection of the outwash train probably started soon after the maximum of the Tazewell substage. Between this time and the Cary substage, the bedrock floor of the trench was lowered possibly as much as 150 feet. During this lowering, contemporaneous intrenchment occurred in tributary valley fills graded to the Missouri River. The intrenchment is best recorded at Dry Run, in the western part of the Canning quadrangle, in which the valley of the present stream has a meandering pattern. The winding flood plain of the stream is incised 30 to 50 feet below the surface of the terrace remnants underlain by Tazewell outwash. It appears that Dry Run flowed in a meandering course on the surface of the outwash, and that the 
meanders became intrenched when the Tazewell outwash was eroded in the Missouri River trench.

Loess deposition probably started soon after the maximum of the Tazewell substage and continued into the Tazewell-Cary interval. During this interval, and probably during the early part of the Cary substage, weathering processes caused the development of an immature soil profile in the upper part of the loess.

\section{CARY SUBSTAGE}

An expansion of the continental glacier during the Cary substage brought an ice sheet into the Pierre area for a third time in the Wisconsin. The glacier failed to reach the maximum extent attained by the Tazewell glacier by 20 miles or more in western Hughes County. The farthest westward advance of the Cary glacier occurred in central Sully County about 12 miles north of the Canning quadrangle (fig. 14). From there the glacier terminus trended southeastward, barely entering the northeast corner of the Canning quadrangle. While the glacier was in the quadrangle, however, a coarse outwash train accumulated in the valley of Medicine Creek. This outwash caused aggradation in the Missouri River, represented by the outwash deposits underlying paired terraces downstream from the mouth of Medicine Creek. The coarse nature of these deposits contrasts strongly with Cary outwash at Pierre, which is predominantly sand and silt. The chief controlling factor probably is distance from source of the outwash: the deposits downstream from Medicine Creek probably were within 8 miles of the ice terminus at the time of deposition; the deposits at Pierre probably were 50 miles from the ice margin in Sully County via Okobojo Creek and the Missouri River.

\section{LATE WISCONSIN AND RECENT TIME}

The youngest Pleistocene deposits inthe area that are recognized with some degree of certainty are of Cary age although the presence of low terrace deposits of sand and gravel in the valley of Medicine Creek near its mouth suggests that melt water flowed in it in Mankato time. Outwash or alluvium of Mankato age has not been recognized in the Missouri River trench although the river likely carried some fine-grained outwash originating at the Mankato ice margin north of the Pierre area.

Since Cary time there has been little change in the morphology of the area. Tributary valleys have been somewhat widened and lengthened headward by stream erosion and mass wasting and deflation has been intermittent, depending on amounts of precipitation, vegetative cover, and wind strength.

\section{STRUCTURE}

\section{GENERAI FEATURES}

The structure of the Pierre shale in and adjacent to the Missouri River trench in South Dakota has been the subject of several investigations by the State Geological Survey (Wing, 1938; Gries, 1939, 1940, Morgan and Petsch, 1945, Wing and Gries, 1941; and others). In general it was found by these workers that fold structures that exist are so broad and low that they can be detected only by planetable mapping.

Structural features in the Pierre shale include faults, gentle folds, and joints; none are sufficiently well exposed or continuous enough in strike to be mapped at the adopted scale. These structures are best exposed in stream banks where weathering and mass-wasting processes have not obscured details of bedding. Faults and folds could nowhere be traced beyond a stream bank or highway backslope; structures in adjacent gullies a few hundred yards apart generally show no relation to each other. Because of a general lack of well-defined lithologic variations in members of the Pierre shale, minor structures are poorly shown. The most useful beds for recognition of structural dislocations of the strata are the bentonite beds in the shale and bentonite facies of the DeGrey member and in the lower part of the Virgin Creek member, and the lithologically distinctive Crow Creek and Mobridge members.

Structures in the Pierre area in some ways resemble structures in the State west of the Missouri River previously described by Russell (1925, 1926a, b), Wilson and Ward (1923), Ward (1925), and Calvert, Beekley, Barnett, and Pischel (1914). These structures are typically represented by the two areas described below.

Russell (1926a, p. 12-13) mapped a northwestwardtrending anticline about 5 miles long, on which are superposed smaller anticlines half a mile to about 2 miles long. Dips on the limbs of these folds are from less than 1 to 6 degrees. The anticlines are cut by many normal faults that trend roughly parallel to the folds and that generally dip toward the fold axis. Concerning these anticlines, Russell (p. 13) noted that

The effect of the faulting is to counteract the rise due to the dip of the beds. The strata rise toward the anticline, but are faulted down so that they are no higher at its axis than they are at some distance from it.

The throw of the faults changes from place to place and is as much as 100 feet. None of the faults can be traced more than half a mile.

In the area investigated by Ward (1925, p. 11),

the structure .... is best described by the term undulatory. This means that there are many small folds, the largest a mile or two long. A northwest-southeast or a northeast-southwest trend: to the folds is apparent but it is not strongly marked. 
Several small faults are present. These are usually short in length and all seem to be of the normal variety. The maximum throw observed was 40 feet.

\section{FOLDS}

The regional structure of west-central South Dakota is a broad, northwestward-plunging syncline, whose axis runs through Kadoka and Philip (fig. 1); the Pierre area lies on the northeast limb of this broad downwarp. There is no definite evidence of this structure in the surface rocks of the Pierre area. Gries (1940, p. 40-41) stated that there is even "an apparent reversal of regional dip in the surface rocks" in northeastern Stanley County. He noted that "the average structural elevation determined in northeastern Stanley County is perhaps 30 feet higher than that in the area south of Pierre."

Possible supporting evidence for Gries' statement lies in a decrease in altitude of the base of the Mobridge member from west to east. In the western part of the Oahe quadrangle the base of the Mobridge is everywhere above an altitude of 1,920 feet and ranges to nearly 2,000 feet. In the southeastern part of the Canning quadrangle the base of the member lies at about 1,830 feet, suggesting an eastward dip of about 5 feet per mile.
In 1938, Wing made a structure-contour map by planetable methods of an area extending along the Missouri River trench from Peoria Bottom to Antelope Creek, and along the Bad River from the west edge of the Pierre quadrangle eastward to the Missouri River. Wing chose a bed of large calcareous concretions that lies near the top of the DeGrey member for a key horizon. His investigation indicated that there are northwestward-trending folds of small amplitude in the area surveyed (fig. 24). These structures have little or no plunge. This circumstance was interpreted by Wing to indicate that the Pierre area is on a structural terrace on the northeast limb of the northwestward-plunging syncline described above.

In the course of geologic mapping, several features were noted by the author that have a bearing on Wing's interpretation of the areal stucture.

1. Altitudes of the contacts between the Virgin Creek, Verendrye, and DeGrey members are remarkably consistent over distances of many miles, although there are local deviations in altitude caused by faulting. For example, the altitude of the contact between the Virgin Creek member and the Verendrye member consistently lies between 1,700 feet and 1,730 feet (where unslumped) over a region that extends from the west edge of the Pierre quadrangle to the east edge of the Canning

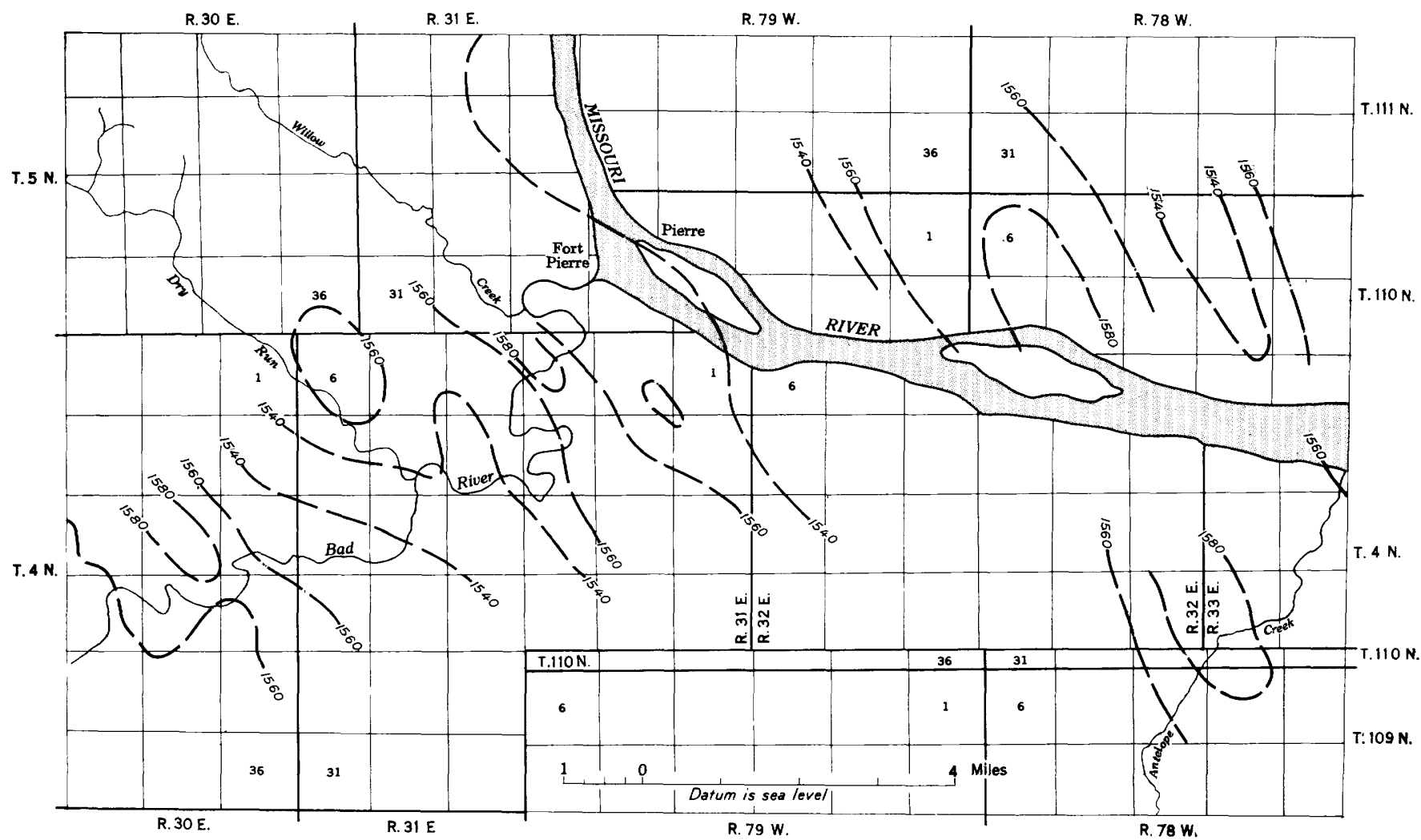

FIGURE 24.--Structure-contour map of part of the Pierre area by M. E. Wing (1938). Contours drawn on a layer of limestone concretions in the upper part of the shale and bentonite facies of the DeGrey member. Structure control interval, 20 feet. 
quadrangle. However, the altitudes of contacts were determined with a Paulin altimeter in the course of geologic mapping; it is therefore likely that these determinations are far less accurate than those resulting from a planetable survey. If fold structures do exist in the Pierre area, they cammot be detected by the method of geologic mapping used in the present inrestigation.

2. The Pierre shale, and particularly the shale and bentonite facies of the DeGrey member, is highly susceptible to slumping. Only rarely are outcrops of the DeGrey member found that are probably in place. No mention of slumping in the shale, however, can be found. in Wing's report. In view of this omission, it is possible that Wing did not recognize the shmped areas. If this is true, some doubt might be placed on his interpretation of the structure of the area.

3. Structures evidently not caused by slumping have been observed at several places along the Bad River (p. 62). They are normal faults with 5 to 20 feet vertical displacement. At one locality, in the SW1/4 sec. 33, T. 5 N., R. 31 E., sereral faults occur on the northeast limb of an anticline mapped by Wing. The beds adjacent to these faults $\operatorname{dip} 10^{\circ}$ to $15^{\circ} \mathrm{SW}$., a direction opposite to that indicated by the structure contours of Wing's map. This small anomaly suggests that Wing's structure contours, at least in detail, are locally inaccurate.

4. In addition to the faults described above, many additional faults have been observed within the area mapped by Wing. Wing's lack of recognition of these structures likewise places some doubt on the accuracy of his structure-contour map.

With few exceptions, the writer observed little or no evidence for the series of northwestward-trending folds shown by Wing. That there are variations in the altitude of contacts between members of the Pierre shale in the area mapped by Wing is not questioned; these variations are, however, more likely related to faults of small displacement and folds of small amplitude and random trend.

Gries (1940) investigated structures in northeastern Stanley County, including the northern part of the Oahe quadrangle. By mapping a key bentonite bed, he outlined a series of northwestward-trending folds (fig. 25). That somewhat more significance can be attached to his work than to Wing's is attested to by the statement by Gries (p. 39) that "the greatest care has been taken to obtain elevations on unslumped outcrops."

In view of the care with which his survey was made, it is indeed remarkable that Gries did not mention in his report the many faults that cut the Pierre shale in the region of his investigation. In mapping the north- ern part of the Oahe quadrangle the author was unable to locate, by means of Paulin altimeter readings on unslumped contacts between members of the Pierre shale, the structures described by Gries. In secs. 15, 16, 22, and 27 , T. 6 N., R. 29 E. Gries shows a northwestwardtrending syncline with an apparent minimum closure of $t 0$ feet. Gries failed to recognize or account for many normal faults in this area, of which one is in the $W_{1 / 2}^{1} \mathrm{SE} 1 / 4$ sec. 15 and another in the SW1/4 SE1/4 sec. 10. It is estimated that 15 to 30 feet of displacement has occurred on these faults. In the $\mathrm{NW} 1 / 4 \mathrm{NE} 1 / 4$ sec. 10 , beds in the Verendrye member dip $10^{\circ} \mathrm{SW}$., whereas Gries' structure-contour map indicates the direction of dip should be northeast.

If the structures mapped by Gries have any continuity upward in the Pierre shale, they should be expressed by altitude variations of the contact between the Mobridge and Virgin Creek members. This contact does vary considerably in altitude, as much as 60 feet within a distance of 500 yards in section 21 . These altitude variations, however, were determined along the southwest limb of the symclime mapped by Gries, along the strike where the altitude of such a contact should be constant.

In summary, the author has found little or no supporting evidence for the fold system shown by Gries; however, this lack of supporting evidence does not by any means constitute proof that such a fold system does not exist. In order to determine with certainty the detailed structure of the region, planetable methods with particular enrphasis on the recognition of slumps and faults must be adopted.

Although many outcrops in stream banks expose strata that are inclined 5 to 15 degrees, these inclined beds generally end abruptly at a fault and on the other side the beds commonly are horizontal or dip in the opposite direction. At many localities it is not possible to determine with certainty whether the dip of the beds is related to regional warping or to local slumping.

Gentle folds of small closure were noted locally; none seem to be persistent along the strike. Several small folds in the Pierre shale are well exposed along backslopes adjacent to U. S. Route 14 in the center of the Oahe quadrangle; these are cut by faults with 5 to 30 feet of vertical displacement. Two faulted symclines in the Virgin Creek member are in the $\mathrm{NE} 1 / 4 \mathrm{NW} 1 / 4$ and the SE1/4NW1/4 sec. 19 , T. 5 N., R. 30 E. An anticlime in the Virgin Creek member in the SE1/4 sec. 26, T. 6 N., R. 28 E. has an exposed maximum height of 6 feet, the fold axis trends N. $50^{\circ} \mathrm{W}$., and the limbs dip about 10 degrees. Pierre shale in an adjacent ex- 


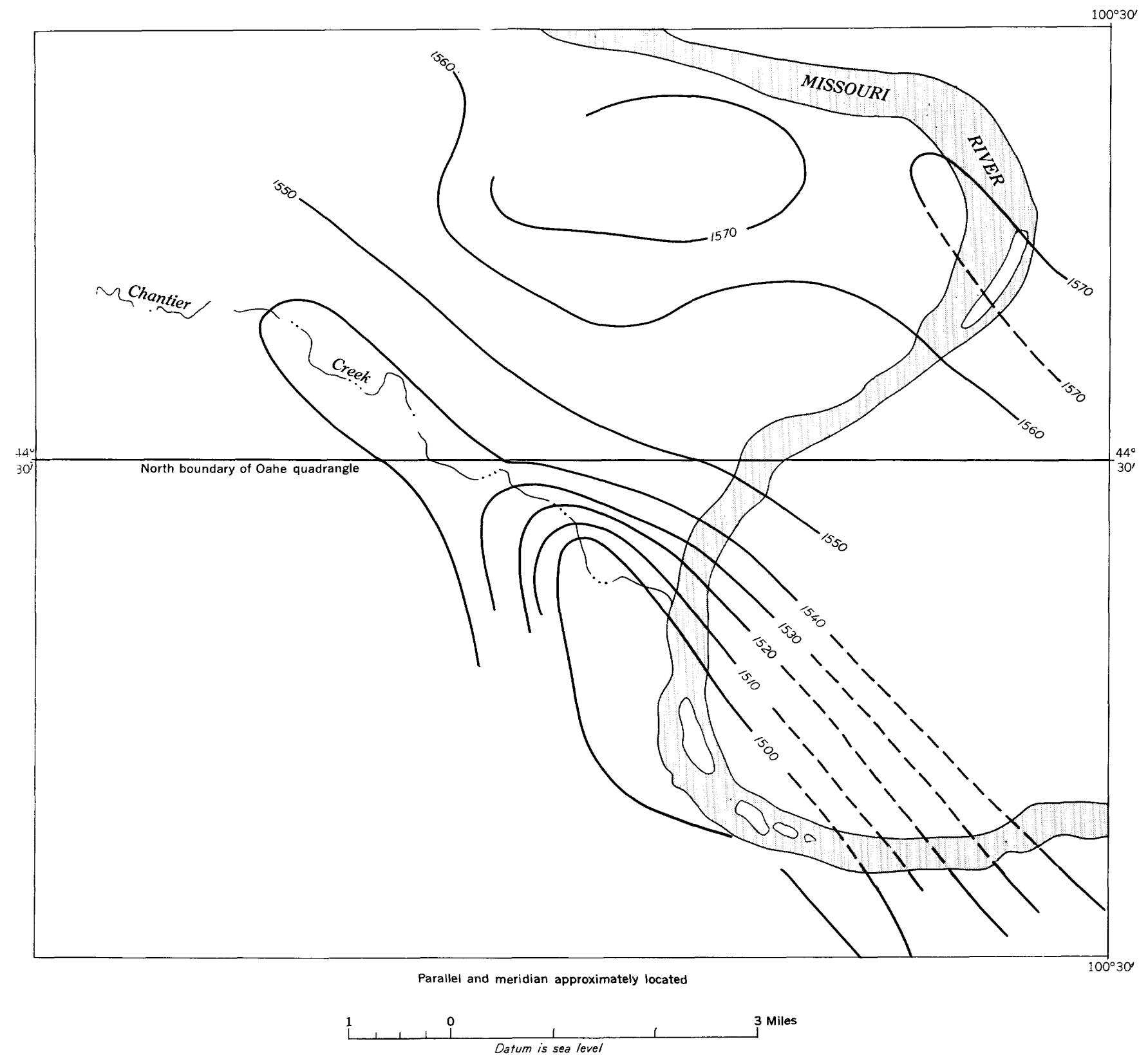

Figure 25.- Part of a structure-contour map of a part of the Pierre area, by J. P. Gries (1940). Contours drawn on a distinctive bentonite bed in the shale and bentonite facies of the DeGrey member. Structure contour interval, 20 feet.

posure several hundred feet to the southeast shows no structural relation to this anticline.

In summary, the Pierre shale locally is warped into gentle folds, small in amplitude and apparently limited in length along the strike to several hundreds of yards.

\section{FAULTS}

The Pierre shale is intricately cut by faults of small displacement; the majority are normal, but reverse faults also are present. No consistent or preferred trend in dip or strike was noted. Because of an everpresent mantle of gumbo over the shale, faults are visible only in natural or artificial cuts, and in no place could they be traced far beyond the immediate outcrop. In many places it is very difficult to determine with certainty whether a displacement of strata is due to faulting or slumping.

Faults have not been plotted on the geologic map because they cannot be represented at the adopted map scale. Faults observable in natural exposures are only a very small proportion of the faults that doubtless exist in the Pierre shale. When the area in the immediate vicinity of the Oahe Dam was mapped, for example, only one fault was noted. Excavation operations until July 
1952 revealed 19 additional faults on the west bank area of the dam alone. Similarly, at least half a dozen faults crop out in backslopes of U. S. High way 14 west of the Missouri River, although on the grass-covered slopes immediately adjacent to the highway no faults are exposed. Because the trace of a fault rarely is exposed for a distance of more than a few tens of feet, these features cannot be accurately represented on the map. Instead, typical examples of faults are described below; faults of this nature doubtless occur thronghout the Pierre shale in the Pierre area.

In the NE $1 / 4$ SW $1 / 4$ sec. 22 , T. 5 N., R. 29 E., Oahe quadrangle, the Virgin Creek and Mobridge members have been brought into contact along a fault that strikes N. $65^{\circ} \mathrm{E}$. and dips $50^{\circ} \mathrm{SE}$. The vertical displacement along this fault cannot be accurately determined, but it is judged to be between 15 and 30 feet. In the NW1/4 sec. 21 , Oahe quadrangle, and the SE1/4 sec. 14, T. 5 N., R. 30 E., Pierre quadrangle, movement along faults in the Virgin Creek member has brought beds of different physical properties into contact. These faults are of particular interest because failures in the highway have occurred coincident with the fault traces (p. 71).

Several faults of small vertical displacement occur in a bank of the Bad River in the SW1/4 sec. 33, T. 5 N., R. 31 E. (fig. 26). Movement along these faults has brought the Crow Creek and Gregory members to the surface, the only localities at which either member is exposed in the Pierre quadrangle. Two of the faults strike N. $55^{\circ}$ to $70^{\circ} \mathrm{E}$. and $\operatorname{dip} 45^{\circ} \mathrm{NW}$. Another fault strikes N. $75^{\circ} \mathrm{W}$. and dips $45^{\circ} \mathrm{SW}$. The maximum vertical displacement is about 18 feet.

Three faults crop out within a short distance laterally in a gully in the SE $1 / 4$ NE1/4 sec. 6, T. 4 N., R. 29 E., Oahe quadrangle (fig. 27). The strike and dip of these faults are, respectively, N. $10^{\circ}$ W., $50^{\circ}$ NE.; N. $25^{\circ}$ W., $45^{\circ}$ NE.; and N. $20^{\circ}$ E., $35^{\circ}$ SE. The total vertical displacement has been about 15 feet. Another interesting structure in the Pierre shale is a faulted anticline exposed in a cut bank of Willow Creek in the NW1/4 sec. 10, T. 5 N., R. 29 E. (fig. 28). These localities illustrate a noteworthy detail of the regional structure: the altitude of contacts and key horizons in the shale is remarkably consistent over large areas, despite an intricate fault system. Thus although a traverse of a given gully might reveal a total stratigraphic displacement of tens of feet, the resulting overall vertical displacement might well be negligible.

The most detailed information concerning structural dislocations in a limited area was obtained by the Corps of Engineers in the course of making excavations in Pierre shale at the site of the Oahe Dam. Until the

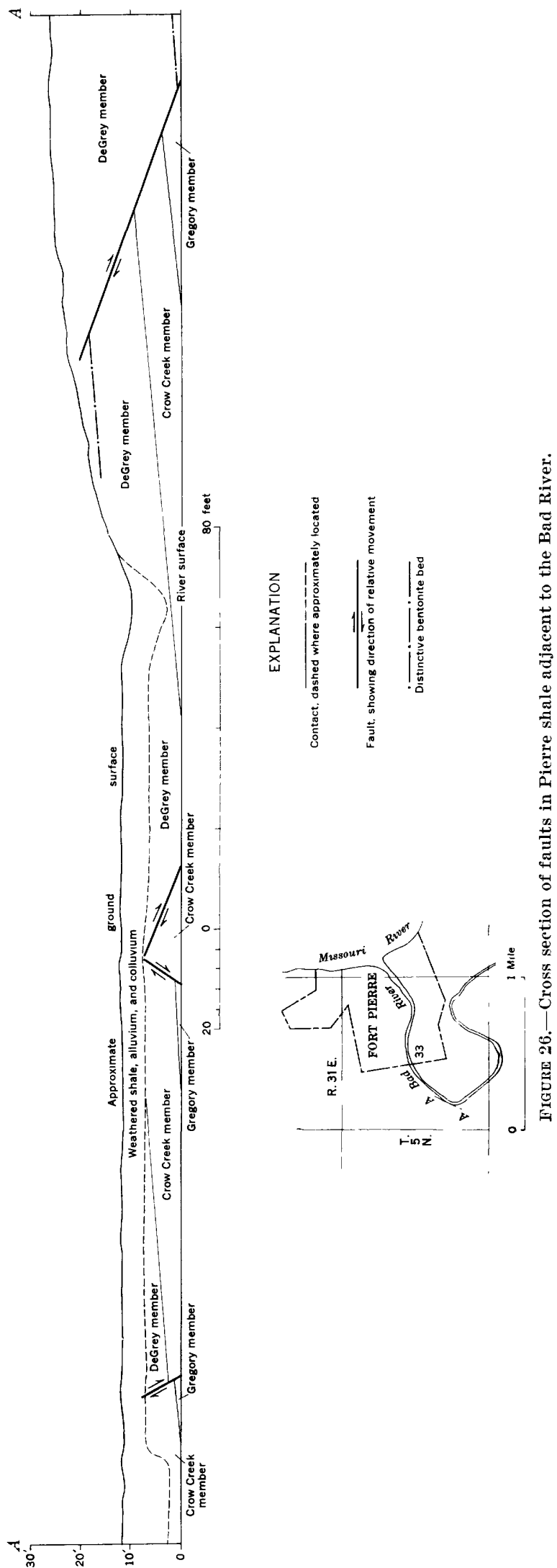




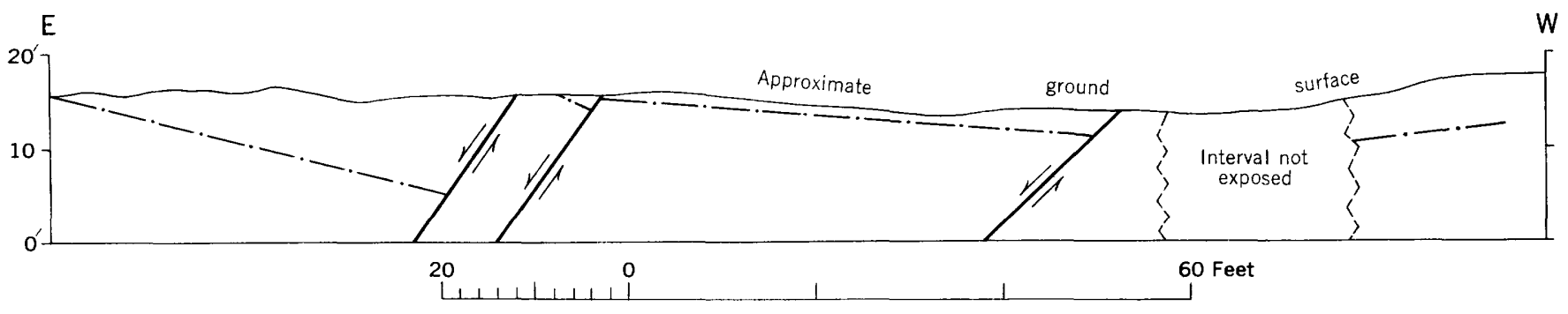

EXPLANATION

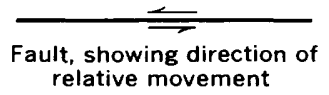

Distinctive bentonite bed

FIgure 27.-Faults in Pierre shale exposed in a gully in SE $1 / 4$ NE1/4 sec. 6, T. 4 N., R. 29 E.

summer of 1952, 19 faults had been recorded, ranging in strike from N. $85^{\circ}$ W. to N. $63^{\circ}$ E., dipping from 25 to 70 degrees, and with a vertical displacement of 5 to 60 feet. It is probable that excavation in the shale of areas in similar size at any other place in the area will reveal fully as many faults as those found at the dam site.

In a few areas, such as in secs. 17,21 , and 27, T. 6 N., R. 29 E., Oahe quadrangle, the altitude of contacts varies considerably within short distances, but faults cannot be located because of poor exposures of shale in place. In the area cited, over a distance of about 3 miles the altitude of the Virgin Creek and Mobridge contact ranges from 1,880 to 1,910 feet, and in sec. 21 , it ranges from 1,880 to 1,940 feet within a distance of 500 yards. Although dipping beds were observed in this area, most of the difference in altitude is believed to be the result of displacement on faults rather than a fold structure.

\section{JOINTS}

Joints occur in each member of the Pierre shale. No joint set or system is readily apparent that has more than local distribution. In excavations at the Oahe Dam, however, measurement of more than 300 joints by the Corps of Engineers shows a distinct northwestward-trending joint set; about 44 percent of the joints strike between N. $30^{\circ} \mathrm{W}$. and N. $60^{\circ} \mathrm{W}$. (fig. 29). These determinations of the joints were made in the Verendrye and DeGrey members. The joints are generally limited to a few feet or tens of feet in vertical extent, and their attitude commonly changes in both dip and strike within a distance of a few tens of feet; it therefore does not necessarily follow that the overlying and underlying members of the Pierre shale have a joint pattern parallel to that of the DeGrey and Verendrye members. Measurement of the orientation of several dozen joints in the Virgin Creek, Mobridge, and Elk

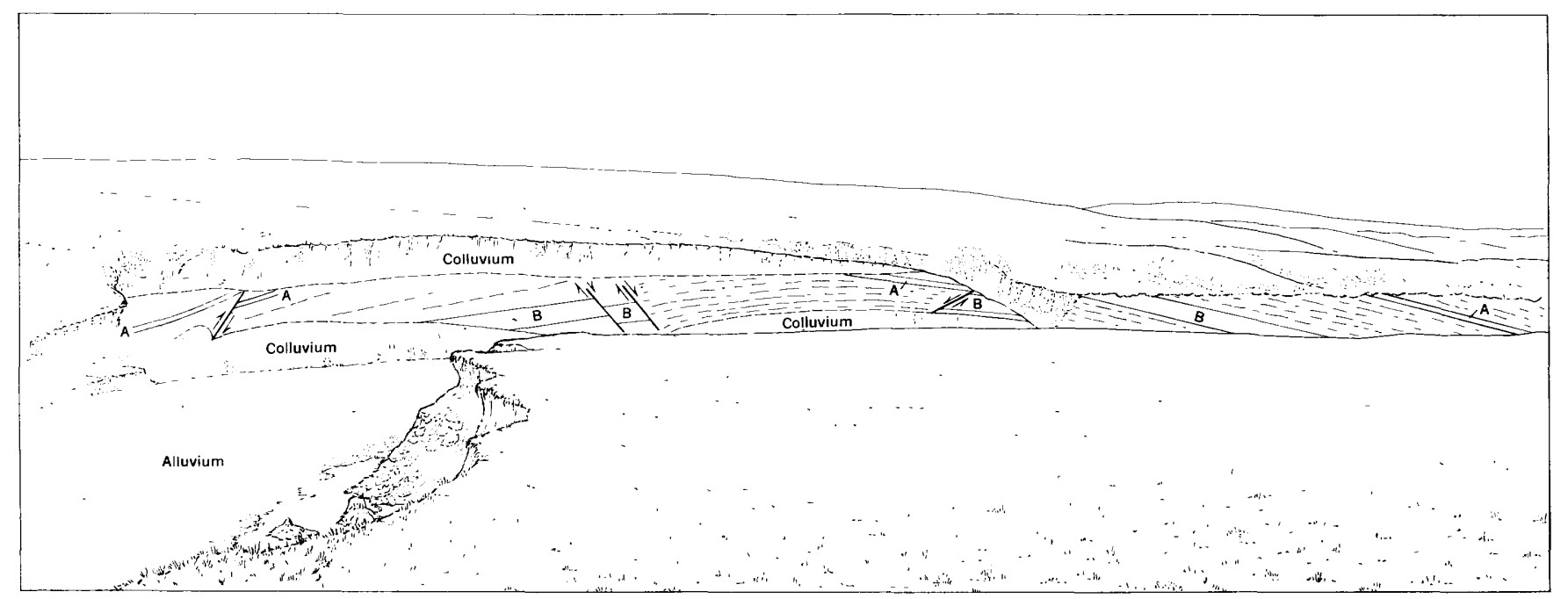

Figcre 28. - Faults in the Virgin Creek member of the Pierre shale in the valley wall of Willow Creek in NW1/4 sec. 10, T. 5 N., R. 29 E. Lines $A$ and $B$ are distinctive pairs of bentonite beds; the stratigraphic distance between the two pairs is 12 feet. Sketched from a photograph. 


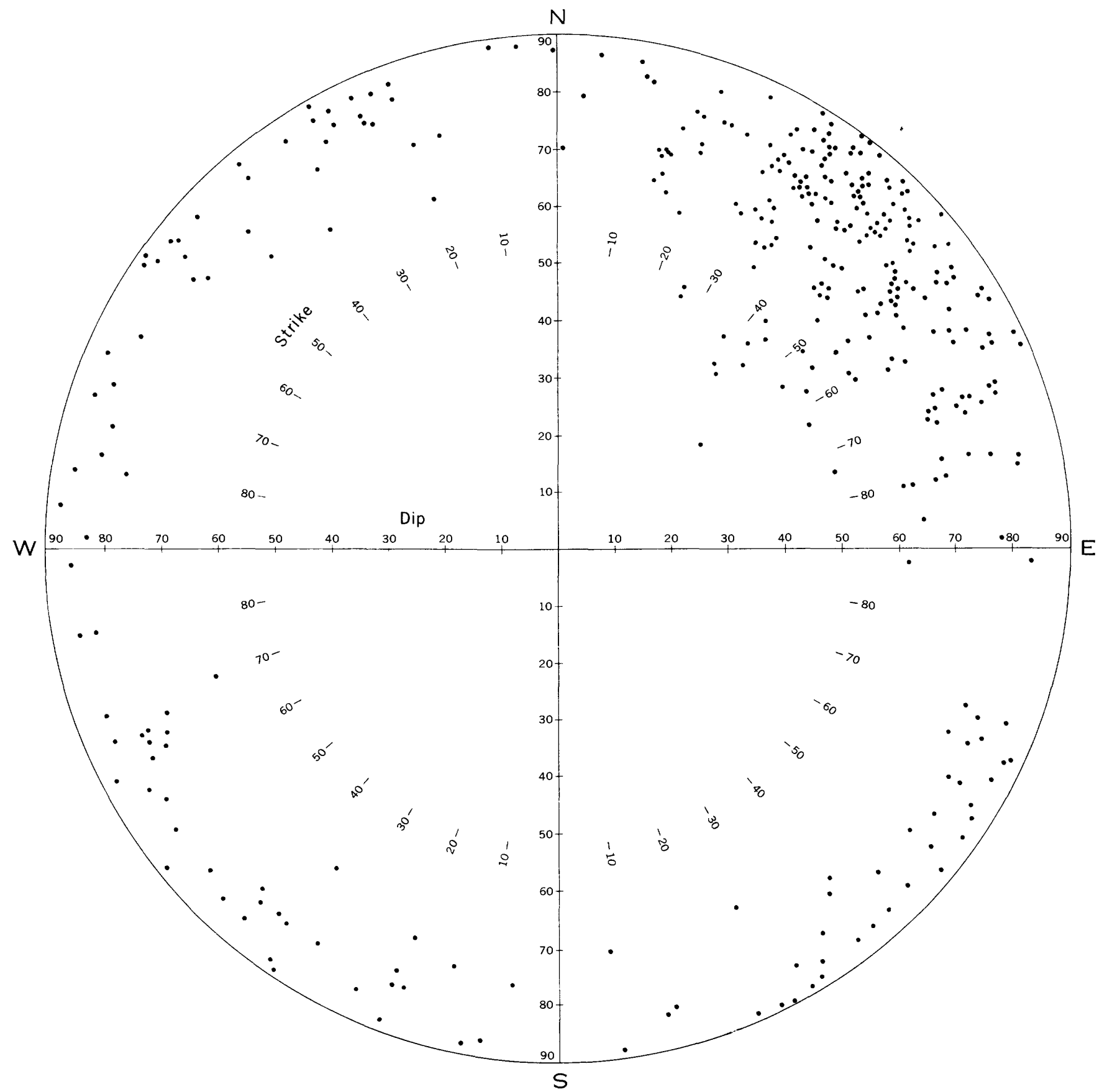

Figure 29.- Polar diagram of joints in Pierre shale at the Oahe dam site. Each dot represents the intersection of a line perpendicular to a joint surface and a sphere. Poles of joints are plotted on the upper hemisphere. From Corps of Engineers joint diagram for joints in the outlet works approach channel excavation, Oahe Dam, 1950. 
Butte members did not reveal a dominant trend; however, this apparent lack of preferred orientation might well be due to the fact that the number of measured joints is greatly below the minimum necessary to make a dominant trend evident.

\section{CAUSE OF DEFORMATION}

Because of total lack of knowledge regarding structures in formations beneath the Pierre shale, it is not possible to predict whether structures in the shale persist at depth. Russell (1925, p. 21-22) suggested the possibility that structures in Pierre shale not only persist at depth, but that the amplitude and closure of folds is much greater at depths than at the surface. In the Pierre area, the apparent lack of uniform trend of structural features in outcrops suggests that the incompetent Pierre shale has warped and fractured in random directions in response to stresses that might be reflected by folds and faults of a more definite pattern in the more competent rocks at greater depths.

Russell (1925, p. 20-21) attributed normal faults to tensional stresses along anticlinal crests caused by upwarping of the strata. Such tensional stresses normally would result in faults or joints that parallel the fold axis. A possible alternative explanation for the normal faulting is that the faults are release fractures caused by extension following the relaxation of compressive stresses.

\section{GEOLOGIC HISTORY}

The pre-Cretaceous history of the Pierre area is one of repeated inundations by epeiric seas in which marine sedimentary rocks were deposited. Details of the sequence of events are not clear because the formations from which the history could be reconstructed are far below the surface and are known only from a few deep borings. The absence of rocks of several systems and many series indicates that deposition very likely was interrupted by periods of nondeposition and perhaps even by intervals of uplift and erosion.

Cretaceous deposition in the area started with the formation of stream and swamp sediments. Before the end of the Early Cretaceous, a shallow sea submerged the area, and although this sea may have temporarily withdrawn, by the beginning of the Late Cretaceous the area again lay beneath a shallow sea in which a considerable thickness of marine sandstone, shale, and limestone was deposited. In the late part of Late Cretaceous time or early in the Cenozoic era the epeiric sea withdrew, and by Eocene time the area was above sea level. Throughout the Eocene and Oligocene, and possibly most of the Tertiary, the area was undergoing erosion, although stream and lake deposits probably were deposited locally from time to time. The record of these sediments has long since been removed by erosion.

In the early part of the Pleistocene epoch the surface of the Pierre area likely was at altitudes ranging from 2,200 to 2,400 feet. Eastward-flowing master streams drained the area. The valley floor of one of the streams coincided with the crests of Standing Buttes and Sully Buttes, a short distance north of the Pierre area and it is possible that this river was the ancestor of the Cheyenne River. The location of the ancestral Bad River before Yarmouth time is not known. Physical evidence of the Nebraskan and Kansan glaciers is not found in the Pierre area. Presumably the area was being lowered slowly by stream erosion, mass wasting, and deflation throughout early Pleistocene time. By late Kansan or early Yarmouth time the ancestral Bad River was flowing across the area in a channel about 6 miles north of the present river. During the Yarmouth stage the ancestral Bad River progressively cut downward and planed southward, leaving veneers of alluvium on abandoned straths cut on Pierre shale. The southeast-oriented tributary drainage system probably originated at this time.

At the beginning of the Illinoian stage the ancestral Bad River was flowing at an altitude of about 1,750 feet at Pierre. Upland surfaces were smoothly graded to the river. The configuration of the surface had been reversed and former lowlands, protected by caps of stream alluvium left along the former and higher channels of the Bad River, now formed the uplands. As the Illinoian glacier advanced into central South Dakota, melt water was ponded ahead of it in the major eastward-trending valleys. The melt water, added to the normal discharge of the eastward-flowing streams, spilled across interfluves and cut a continuous channel when the margin of the Illinoian glacier reached the approximate position of the present Missouri River.

This cutting of the Missouri River trench rejuvenated the preexisting streams of the area. Stream erosion and mass wasting during the Sangamon stage enlarged the trench to its present width and nearly to its present depth. So far as known, all glacial deposits of the Illinoian stage were removed during this period of erosion.

In the Wisconsin stage the Iowan glacier crossed the Missouri River trench and extended over nearly the entire Oahe quadrangle. Before the melt water could again overflow and cut new spillways through interfluves, the ice margin retreated to a position east of the Missouri River trench. In the course of this eastward retreat, melt water that discharged down tributary ralleys contributed outwash to an aggrading alluvial 
fill in the Bad River trench. Melt water from the ice margin in and adjacent to the Missouri built a similar outwash fill in the trench of that river extending up to an altitude of about 1,700 feet. The Iowan glacial drift filled in and smoothed out the preexisting rough topography formed by dissection in Sangamon time.

Although evidence of an appreciable time interval between the Iowan and Tazewell substages is lacking, at least 150 feet of downcutting occurred in the Iowan outwash fill in the Missouri trench during this time.

The advance of a glacier in the Tazewell substage further filled in and smoothed out preexisting topographic irregularities. Although the Tazewell ice pushed into the Missouri River trench at most places in the area, there is no evidence that it moved onto the upland southwest of the river. Melt water from Tazewell ice lying in the trench, and later flowing into the trench by way of Spring Creek and Dry Run, built an outwash train in the Missouri. When the Tazewell glacier melted back to Medicine Creek, the valley of that stream also was partly filled by outwash.

With the disappearance of the Tazewell glacier from the Pierre area, dissection started in the outwash deposits. Very likely the present bedrock floor of the trench was cut during the Tazewell-Cary interval. Winds deflated silt from the Missouri flood plain and deposited the material on terraces in the trench and on adjacent upland surfaces. Before a glacial climate had again set in, oxidation, leaching, and humification produced an immature soil profile in the loess.

The Cary glacier did not extend as far west as the Tazewell glacier, and the outermost edge of the ice sheet reached only the northeast corner of the Canning quadrangle. Stratified drift derived from this ice margin was deposited in the trench of Medicine Creek, where it now occurs as terrace remnants. It is likely that the Missouri River aggraded to an altitude at least 20 feet above the present flood plain in response to the contribution of Cary outwash.

The maximum of the Cary substage was accompanied and followed by deflation of sediment from. Cary drift and the deposition of this material as loess. Before the maximum of the following Mankato substage, the Cary outwash fill had been dissected.

The margin of the Mankato glacier reached northeastern Hughes County, and the only Mankato glacial deposits in the Pierre area are bodies of fine-grained outwash. So far as known, loess deposition has been almost continuous from the time of the Mankato maximum to the present.

The surface of the Pierre area now is being slowly lowered by stream erosion, deflation, and mass-wasting processes. Soil profiles in loess are less well developed than those developed during the Tazewell-Cary interval. This suggests that either a longer time existed between the Tazewell and Cary substages than from the Mankato maximum to the present, or that the Tazewell-Cary break was characterized by a warmer and moister climate than the present one, or both.

\section{ECONOMIC GEOLOGY}

NATURAL RESOURCES

There are virtually no mineral deposits in the Pierre area; the only fuel resource known is natural gas. The most abundant natural resources are construction materials; some, such as sand and gravel, are presently being utilized; others, such as Pierre shale for lightweight aggregate, have not yet been developed.

\section{SAND AND GRAVEL}

Glacial-outwash terrace deposits constitute the largest source of sand and gravel in the Pierre area. Tests run on samples of this material by the Corps of Engineers ${ }^{8}$ indicate, however, that it is a fair to poor source of aggregate for use in high-grade concrete because it contains physically or chemically deleterious constituents.

Glacial outwash deposits are characterized by common rock types wherever found. A generalized breakdown of the component parts, based on counts of 200 pebbles, 1 to 2 inches in diameter, from a large number of gravel pits in the Canning and Pierre quadrangles is tabulated below.

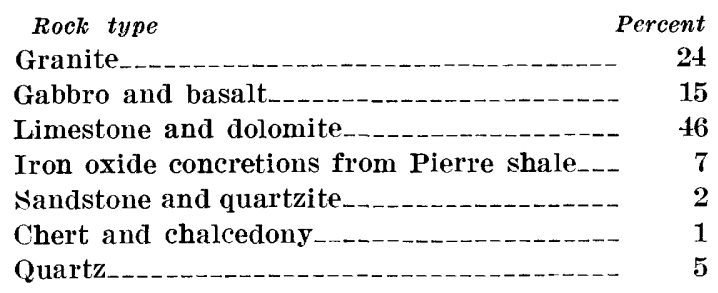

The largest deposits occur within the Missouri River trench, and the valleys of Dry Run and Medicine Creek in the Canning quadrangle contain local deposits. Although outwash deposits generally contain from 80 to 90 percent material 2 inches in diameter or smaller, boulders as large as 5 feet in diameter are common in some deposits. At present the chief use of these deposits is road surfacing. The composition and volume of the largest and most readily accessible outwash deposits in the area are discussed by Rothrock (1944, p. 43-55).

\footnotetext{
s Report on test to determine reactivity of natural sand with alkalis in portland cement, Soils and Materials Laboratory, Omaha District, Corps of Engineers, U. S. Army, March 29, 1949.
} 
Southwest of the Missouri River, the chief source of sand and gravel is the deposits of high-level alluvium; these are thin and small in areal extent in most places. One of the deposits, however, provided an adequate source of aggregate for the bituminous surfacing of part of U. S. Highway 14 west of the Missouri River in 1947 . This outcrop is in sec. 26, T. 5 N., R. $29 \mathrm{E}$.; it is estimated that not much more than 10 percent of the deposit was removed. Channel samples, tested by the South Dakota State Highway Department (E. E. Meleen, assistant materials engineer, written communication, January 21,1953 ), from a 17 foot anger hole in the center of the deposit indicated that 7 percent at that locality was coarser than 0.187 inches, 66 percent was coarser than 0.0029 inches, and 27 percent was finer than 0.0029 inches. The liquid limit of the material ranges from 17.3 to 32.3 percent and averages 24 percent; the plasticity index ranges from 1.5 to 14.0 percent and averages 6.8 percent.

The range in variations in physical properties probably is as great laterally as it is in the vertical auger hole. This outcrop is believed to be typical of the high-level deposits of sand and gravel of western origin, although locally there is more pebble gravel than at the locality described. Low-level deposits of alluvium adjacent to the Bad River consist predominantly of sand and pebble gravel. Locally, as in the $\mathrm{NE} 1 / 4$ sec. 9, T. 4 N., R. 31 E., the sand and gravel are overlain by coarse- to medium-grained sand. The largest pit opened in these low-level deposits of alluvium is west of the Bad River at the south edge of the Oahe quadrangle; the material was used in the construction of U. S. Highway 14. Crushed aggregate prepared from material taken from this pit was found to have liquid limits ranging from 31.8 to 39.8 percent and plasticity indexes ranging from 16.2 to 22.9 percent (E. E. Meleen). A large deposit of this low-level alluvium lies south of the Bad River in secs. 3 and 4, T. 3 N., R. 29 E., and extends southward beyond the south edge of the Oahe quadrangle.

\section{HARD ROCK}

Glacial erratics are the only source of hard rock in the area. These boulders are widely scattered over the entire area southwest of the Missouri River except in the extreme southwestern corner of the Oahe quadrangle. Over most of the upland area northeast of the Missouri, boulders lying on the surface are rare because of the mantle of loess. There is, however, a concentration that extends from the center of sec. 33 to the center of sec. 34 , T. 110 N., R. $78 \mathrm{~W}$. in the western part of the Canning quadrangle. Many boulders also are exposed on the flanks of both Medicine Knoll and
Snake Butte. The most extensive boulder concentrations are on the northeast wall of the Missouri River trench. The largest and most accessible of the concentrations extends from the SW1/4 sec. 1, T. 110 N., R. 79 W. in the Pierre quadrangle into sec. 9, T. 110 N., R. 78 W. in the Canning quadrangle, a distance of nearly 4 miles. (fig. 15). About 90 percent of the boulders are of unweathered granite or granitic rock; the remaining 10 percent includes basic rock types, schist, and carbonate rocks. About 95 percent of the boulders are between 1 and 6 feet in diameter, and most are partly rounded. It is estimated that in this concentration there are at least 600,000 boulders that have a total volume of at least 250,000 cubic yards. About twothirds of the boulders are on the valley wall of the Missouri River trench; the other third is between the valley wall and Chicago and North Western Railway. The boulders in this concentration appear to be suitable as a source of riprap, or probably would be an adequate source for a crushing mill to produce concrete aggregate. Boulders from the concentration were used by the Civilian Construction Corps during the 1930's in the construction of a causeway from the north bank of the Missouri River to Farm Island.

A smaller boulder concentration lies in the northeastern part of the Oahe quadrangle in the NW1/4 sec. 23, T. 112 N., R. 81 W., and in an adjoining area north of the quadrangle. The sole concentration of erratics southwest of the Missouri River consists of only several hundred boulders; it is located in the $\mathrm{SW} 1 / 4$ sec. 10 , T. 4 N., R. 29 E., in the Oahe quadrangle.

\section{FILL MATERIAL}

Nearly all the bedrock units and surficial deposits that occur in the area have been used at one time or another for fill material. In some places the performance of these materials has not been satisfactory. In two construction projects in recent years, for example, contractor's have had particular difficulty in making stable fills of adequate compactness of fan alluvium and colluvium.

In general Pierre shale is considered to be a poor material for use in constructing highway fills. In many places south west of the Missouri River, however, no substitute is readily available. Mixing permeable material such as sand and gravel with Pierre shale generally improves it. Where obtainable, till and loess have been used successfully as fill material. These materials are widely distributed over most of the area northeast of the Missouri River.

Soil test data for most of the map units are given in the following table. 


\section{Soil test data}

[These data were determined by the Soils Laboratory of the South Dakota Highway Commission (A. W. Potter, Materials Engineer, unpublished communieations Nov. 27,1950 , and June 27,1952 ) from samples collected from the Pierre, Canning, and Oahe quadrangles and submitted by the author. The test analyses were run aceording to A. S. T. M. standard specifleations.]

\begin{tabular}{|c|c|c|c|c|c|c|c|c|c|c|c|}
\hline & \multirow{2}{*}{\multicolumn{3}{|c|}{ Tributary alluvium and colluvium 1}} & \multicolumn{8}{|c|}{ Pierre shale } \\
\hline & & & & \multirow{2}{*}{\multicolumn{3}{|c|}{ Glacial drift (till) }} & \multirow{2}{*}{\multicolumn{2}{|c|}{ Loess }} & \multirow{3}{*}{$\begin{array}{c}\begin{array}{c}\text { Elk Butte } \\
\text { member }\end{array} \\
\text { Lower } \\
\mathrm{SW1} / 4 \mathrm{sec} . \\
20 \mathrm{~T} .5 \mathrm{~N} . \\
\text { R. } 29 \mathrm{E} .\end{array}$} & \multicolumn{2}{|c|}{ Mobridge member } \\
\hline & \multirow{2}{*}{\begin{tabular}{|l} 
Sample 1 \\
SW1/4sec. 2 \\
T. $110 \mathrm{~N} .$, \\
R. $79 \mathrm{~W}$.
\end{tabular}} & \multirow{2}{*}{\begin{tabular}{|c} 
Sample 2 \\
NE1/4 see. \\
$11 \mathrm{~T} .4 \mathrm{~N}$. \\
R. $31 \mathrm{E}$.
\end{tabular}} & \multirow{2}{*}{$\begin{array}{c}\text { Sample } 3 \\
\text { SE1/4 sec. } \\
20 \mathrm{~T} .5 \mathrm{~N} ., \\
\text { R. } 31 \mathrm{E} .\end{array}$} & & & & & & & Lower & Upper \\
\hline & & & & $\begin{array}{l}\text { SW1/4 sec. } \\
36 \text { T. } 111 \\
\text { N., R. } 79 \\
\text { W. }\end{array}$ & $\begin{array}{c}\text { Center of } \\
\text { sec. } 31 \mathrm{~T} \text {. } \\
112 \mathrm{~N}_{\text {. }} \mathrm{R} . \\
77 \mathrm{~W} .\end{array}$ & $\begin{array}{c}\mathrm{NW} 1 / 4 \text { sec. } \\
6 \mathrm{~T} .111 \mathrm{~N} . \\
\mathrm{R} .79 \mathrm{~W} .\end{array}$ & $\begin{array}{c}\text { SE corner } \\
\text { or sec. } 6 \mathrm{~T} \text {. } \\
111 \mathrm{~N} ., \mathrm{R} \text {. } \\
79 \mathrm{~W} .\end{array}$ & $\begin{array}{c}\text { NW1/4 sec. } \\
27 \mathrm{~T} .111 \\
\text { N., R. } 79 \\
W .\end{array}$ & & $\begin{array}{c}\text { SW1/4 sec. } \\
22 \text { T. } 5 \mathrm{~N} ., \\
\text { R. } 29 \mathrm{E} \text {. }\end{array}$ & $\begin{array}{l}\text { SW1/4 sec. } \\
20 \text { T. } 5 \mathrm{~N} ., \\
\text { R. } 29 \mathrm{E} .\end{array}$ \\
\hline \multirow[t]{5}{*}{ 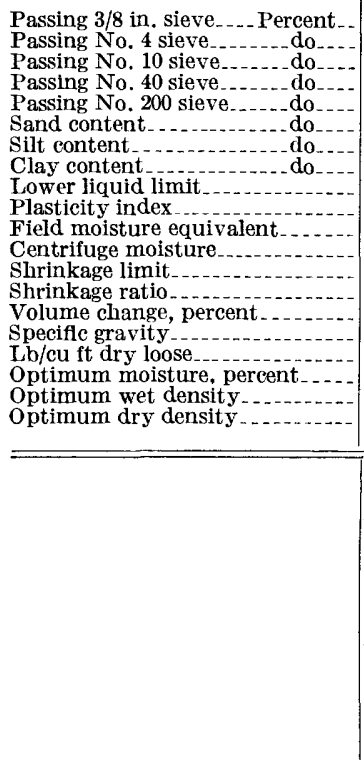 } & \begin{tabular}{r|}
98. \\
96.3 \\
89.3 \\
81.3 \\
73.8 \\
30.2 \\
26.8 \\
32.3 \\
62.1 \\
36.8 \\
27.9 \\
26.8 \\
14.2 \\
1.87 \\
25.68 \\
2.54 \\
66.9 \\
31.8 \\
113.1 \\
85.4
\end{tabular} & \begin{tabular}{|r|}
100.0 \\
100.0 \\
100.0 \\
99.4 \\
97.8 \\
16.8 \\
25.6 \\
57.6 \\
77.4 \\
49.3 \\
31.3 \\
74.7 \\
13.9 \\
1.93 \\
33.6 \\
2.64 \\
64.5 \\
\hdashline \\
\end{tabular} & $\begin{array}{r}100.0 \\
100.0 \\
100.0 \\
99.6 \\
97.8 \\
14.8 \\
26.0 \\
59.2 \\
82.2 \\
53.7 \\
28.2 \\
67.5 \\
12.5 \\
1.95 \\
30.6 \\
2.58 \\
63.3 \\
22.6 \\
103.0 \\
83.7\end{array}$ & \begin{tabular}{l}
99.0 \\
98.2 \\
89.6 \\
79.2 \\
66.9 \\
36.0 \\
21.7 \\
31.9 \\
53.07 \\
27.1 \\
25.7 \\
23.0 \\
20.8 \\
1.74 \\
8.5 \\
2.73 \\
64.8 \\
\hdashline..- \\
\hdashline-1.
\end{tabular} & \begin{tabular}{|c|}
98.3 \\
96.7 \\
92.3 \\
83.6 \\
68.5 \\
38.9 \\
25.9 \\
27.5 \\
44.5 \\
20.9 \\
23.9 \\
23.0 \\
13.5 \\
1.79 \\
18.6 \\
2.36 \\
64.5 \\
\hdashline \\
-
\end{tabular} & \begin{tabular}{|c|}
99.3 \\
97.7 \\
92.3 \\
79.6 \\
68.1 \\
44.5 \\
22.2 \\
25.6 \\
44.4 \\
19.4 \\
24.9 \\
26.7 \\
18.1 \\
1.75 \\
12.0 \\
2.56 \\
65.1 \\
-0.9
\end{tabular} & $\begin{array}{r}100.0 \\
100.0 \\
100.0 \\
99.8 \\
97.0 \\
29.6 \\
43.2 \\
27.2 \\
37.7 \\
17.1 \\
17.9 \\
21.7 \\
16.7 \\
1.81 \\
2.17 \\
2.60 \\
61.8\end{array}$ & \begin{tabular}{c}
100.0 \\
100.0 \\
100.0 \\
160.0 \\
98.2 \\
25.8 \\
47.0 \\
27.2 \\
43.2 \\
21.1 \\
19.4 \\
18.5 \\
16.0 \\
1.85 \\
6.31 \\
2.63 \\
67.5 \\
\hdashline.--- \\
\hdashline---
\end{tabular} & $\begin{array}{c}0.9 \\
34.6 \\
39.3 \\
85.5 \\
16.7 \\
1.73 \\
39.1 \\
2.43 \\
64.3 \\
\end{array}$ & $\begin{array}{c} \\
61.9 \\
34.7 \\
30.59 \\
69.2 \\
18.4 \\
1.74 \\
21.28 \\
2.56 \\
75.1\end{array}$ & \begin{tabular}{|c} 
\\
\end{tabular} \\
\hline & \multicolumn{11}{|c|}{ Pierre shale-Continued } \\
\hline & \multicolumn{4}{|c|}{ Virgin Creek member } & \multicolumn{3}{|c|}{ Verendrye member } & \multicolumn{4}{|c|}{ DeGrey member } \\
\hline & Lower & Middle & \multicolumn{2}{|c|}{ Upper } & Lower & Middle & Upper & Lower & \multicolumn{2}{|c|}{ Upper } & Bentonite \\
\hline & $\begin{array}{c}\text { SE1/4 sec. } \\
29 \text { T. } 5 \text { N., } \\
\text { R. } 31 \text { E. }\end{array}$ & $\begin{array}{c}\text { NW1/4 sec. } \\
14 \text { T. } 5 \text { N., } \\
\text { R. } 31 \text { E. }\end{array}$ & $\begin{array}{c}\mathrm{SE1} / 4 \mathrm{sec} \\
28 \mathrm{~T} .5 \mathrm{~N} . \\
\text { R. } 29 \mathrm{E} .\end{array}$ & $\begin{array}{c}\text { SW1/4 sec. } \\
22 \text { T. } 5 \mathrm{~N} ., \\
\text { R. } 29 \text { E. }\end{array}$ & $\begin{array}{c}\text { SE1/4 SW } 1 / 4 \\
\text { sec. } 28 \text { T., } \\
5 \text { N., R. } 31 \\
\text { E. }\end{array}$ & $\begin{array}{l}\text { SW1/4 sec. } \\
28 \text { T. } 5 \mathrm{~N} . \\
\text { R. } 31 \mathrm{E} .\end{array}$ & $\begin{array}{l}\text { SW corner } \\
\text { of sec. } 28 \\
\text { T. } 5 \mathrm{~N} ., \mathrm{R} . \\
31 \mathrm{E} .\end{array}$ & $\begin{array}{l}\text { SW1/4 sec. } \\
29 \text { T. } 111 \\
\text { N.. R. } 79 \\
\text { W. }\end{array}$ & $\begin{array}{c}\text { SE1/4 sec. } \\
20 \text { T. } 5 \text { N., } \\
\text { R. } 31 \mathrm{E} .\end{array}$ & $\begin{array}{c}\text { SE1/4 sec. } \\
20 \text { T. } 5 \text { N.; } \\
\text { R. } 31 \text { E. }\end{array}$ & $\begin{array}{l}\text { SE1/4 sec. } \\
20 \text { T. } 5 \mathrm{~N} . \\
\text { R. } 31 \mathrm{E} .\end{array}$ \\
\hline $\begin{array}{l}\text { Passing } 3 / 8 \text { in. sieve }- \text { Percent } \\
\text { Passing No. } 4 \text { sieve.-. }\end{array}$ & & & & & & & & & & & \\
\hline $\begin{array}{l}\text { Passing No. } 10 \text { sieve } \\
\text { Passing No. } 40 \text { sieve }\end{array}$ & & & & & & & $\cdots \cdots$ & ( n & (n) & 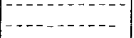 & --1 \\
\hline $\begin{array}{l}\text { Passing No. } 40 \text { sieve } \\
\text { Passing No. } 200 \text { sieve }\end{array}$ & & & & & & & & & & & \\
\hline $\begin{array}{l}\text { Sand content } \\
\text { Silt content }\end{array}$ & & & & & & & & & & & \\
\hline $\begin{array}{l}\text { Silt content } \\
\text { Clay content. }\end{array}$ & $-\cdots-1$ & & & & & & & & & & \\
\hline Lower liquid limit.-. & 63.9 & 70.8 & 80.0 & 77.0 & 148.6 & 77.8 & 77.0 & 74.4 & 40.4 & 106.4 & 312.5 \\
\hline & 34.8 & 42. 9 & 45.0 & 49.4 & 106. 9 & 46.4 & & 32 & & & 273.2 \\
\hline & 29.1 & 26.2 & 39.8 & 31.96 & 32.1 & 29 & 30. & 44 & & 37. & 42.5 \\
\hline Centrifuge moisture & 45.9 & 81.0 & 52.8 & 94.8 & 94.7 & 54.4 & 43.5 & & 48.9 & 97. & 102.4 \\
\hline $\begin{array}{l}\text { Shrinkage limit } \\
\text { Shrinkage ratio }\end{array}$ & 12.7 & 14.3 & 15.4 & 14. 2 & 15.1 & 13.5 & 13. 9 & 28. & 32.8 & 19. & 8. 5 \\
\hline $\begin{array}{l}\text { Shrinkage ratio } \\
\text { Volume change, percent }\end{array}$ & 1.94 & 1.95 & 1.87 & 1.88 & 1.91 & 2.05 & 1.93 & 1.47 & 1. 37 & 1.71 & 2.03 \\
\hline $\begin{array}{l}\text { Volume change, percent } \\
\text { Speciflc gravity }\end{array}$ & 31.9 & 23.2 & 45.5 & 33.37 & 10.1 & 32.8 & 31.6 & 23.5 & 17.2 & 31.3 & 69.0 \\
\hline $\begin{array}{l}\text { Speciflc gravity } \\
\text { Lb/cu ft dry loose }\end{array}$ & $\begin{array}{l}2.58 \\
65.5\end{array}$ & 2.70 & 2. 63 & 2. 57 & 2. 68 & 2.84 & 2.64 & 2. 54 & 2.49 & 2. 53 & 2.46 \\
\hline & & 66.4 & & 68.1 & 56.1 & & 62,3 & 47.9 & 54.3 & 57.1 & 62.1 \\
\hline $\begin{array}{l}\text { percent } \ldots . . .- \\
\text { ty }\end{array}$ & $\begin{array}{r}30.0 \\
112.2\end{array}$ & & $\begin{array}{r}23.0 \\
108.5\end{array}$ & & & $\begin{array}{r}27.2 \\
110.3\end{array}$ & & & & & \\
\hline Optimum dry density & 86.2 & (n) & 88.3 & & & 86.4 & & & - & & \\
\hline
\end{tabular}

1 Sample 1 consists of weathered and reworked Pierre shale and reworked sand and gravel. The content of sand and gravel is probably responsible for the comparatively low plasticity index and lower liquid limit. This general type of $Q f a$ can be expected where the map shows deposits of sand and gravel upslope from the Qfa unit. Samples 2 and 3 consist almost entirely of weathered and reworked Pierre shale. This type of Qfa will be found in areas where there is no source of sand and gravel directly upslope from the deposit. 


\section{pierre shale as a possible source of} LIGHTWEIGHT AGGREGATE

A preliminary investigation has indicated that some parts of the Pierre shale in the Pierre area have properties that are desirable in the production of lightweight aggregate for concrete. Lightweight concrete aggregate is produced from certain shale and clay deposits by rapid heating in a rotary kiln; at high temperatures some constituents generate gas or vapor that expands and forms bubbles or cells in the semiplastic shale or clay. The product, in the case of a shale having desirable bloating properties, is a cellular fragment of low density and high compressive strength.

Six samples of Pierre shale were submitted in March 1954 to the Bureau of Mines for preliminary bloating tests. In the laboratory representative portions of the samples were sized to fragments larger than one-fourth inch and smaller than three-eighths inch, heated to about $700^{\circ} \mathrm{C}$., and then placed in an electric muffle furnace and fired to temperatures of $1,100^{\circ}$ to $1,340^{\circ} \mathrm{C}$. The results of the tests are summarized below. These are preliminary tests and indicate only that portions of the Pierre shale near Pierre are worthy of further, more comprehensive testing.

Bloating characteristics of Pierre shale samples

[Test data provided by the Bureau of Mines, Department of the Interior]

\begin{tabular}{|c|c|c|c|c|c|c|c|c|}
\hline \multirow{2}{*}{$\begin{array}{l}\text { Sample No. } \\
\text { (arranged } \\
\text { in order of } \\
\text { decreasing } \\
\text { quality) }\end{array}$} & \multirow{2}{*}{$\begin{array}{l}\text { Method of } \\
\text { sampling }\end{array}$} & \multirow{2}{*}{$\begin{array}{l}\text { Shale member and } \\
\text { description }\end{array}$} & \multirow{2}{*}{ Location } & \multirow{2}{*}{$\begin{array}{l}\text { Bloating } \\
\text { temperature } \\
{ }^{\mathrm{C} .}\end{array}$} & \multirow{2}{*}{$\begin{array}{l}\text { Bloating } \\
\text { range } \\
\circ \mathrm{C} .\end{array}$} & \multirow{2}{*}{ Appearance of bloated product } & \multicolumn{2}{|c|}{$\begin{array}{l}\text { Approximate } \\
\text { diameter of cells }\end{array}$} \\
\hline & & & & & & & $\begin{array}{c}\text { Average } \\
(\mathrm{mm})\end{array}$ & $\underset{(\mathrm{mm})}{\text { Largest }}$ \\
\hline $1 \ldots$ & Grab..... & $\begin{array}{l}\text { Virgin Creek } \\
\text { (Lowermost beds). }\end{array}$ & $\begin{array}{l}\text { SE1/4SW1/4 sec. } 28, T .111 \text { N., R. } \\
79 \text { W.; road cut adjacent to U. S. } \\
\text { Highway } 14 .\end{array}$ & $1,110-1,320$ & 210 & $\begin{array}{l}\text { Dull, light tan, very well } \\
\text { rounded, no sticking below } \\
1,280^{\circ} \mathrm{C} \text {. }\end{array}$ & 0.5 & 2. 0 \\
\hline $2 \ldots$ & $\begin{array}{l}10 \text { grabs, } 8 \text { to } 60 \\
\text { feet below top } \\
\text { of facies. }\end{array}$ & $\begin{array}{l}\text { DeGrey member } \\
\text { (Upper } 60 \text { feet of } \\
\text { siliceous shale } \\
\text { facies). }\end{array}$ & $\begin{array}{l}\text { SW1/4W } 1 / 4 \text { sec. } 29, T .111 \mathrm{~N} ., \mathrm{R} \\
79 \mathrm{~W} ., \text { outcrop on east bank of } \\
\text { Missouri River north of Pierre. }\end{array}$ & $1,180-1,340$ & 160 & $\begin{array}{l}\text { Dull to slight gloss, slightly } \\
\text { sticky, light brown, well } \\
\text { rounded. }\end{array}$ & 0.5 & 2.0 \\
\hline $3 \ldots$ & Grab & $\begin{array}{l}\text { Verendrye member } \\
\text { (Basal beds). }\end{array}$ & $\begin{array}{l}\text { NE1/4NW1/4 sec. } 33, \mathrm{~T} .5 \mathrm{~N} ., \mathrm{R} . \\
79 \mathrm{~W} \text {; at Verendrye Monument, } \\
\text { Fort Pierre. }\end{array}$ & $1,120-1,260$ & 140 & $\begin{array}{l}\text { Slight gloss, moderate stick- } \\
\text { ing, light brown, angular to } \\
\text { rounded. }\end{array}$ & 1.0 & 4.0 \\
\hline $4 \ldots$ & $\mathrm{Grab}_{\ldots}$ & $\begin{array}{l}\text { Verendrye member } \\
\text { (Uppermost beds). }\end{array}$ & $\begin{array}{l}\text { SE1/4SW1/4 sec. } 28, T .111 \text { N., R. } 79 \\
\text { W.; road cut adjacent to U. S. } \\
\text { Highway } 14 .\end{array}$ & $1,160-1,280$ & 120 & $\begin{array}{l}\text { Dull to slight gloss, no sticking } \\
\text { below } 1,240^{\circ} \text { C., slightly } \\
\text { rounded, sharp edges. }\end{array}$ & 0.8 & 3.0 \\
\hline 5 & Grab.-- & $\begin{array}{l}\text { DeGrey member } \\
\text { (Shale and bento- } \\
\text { nite facies). }\end{array}$ & $\begin{array}{l}\text { SE1/SE1/4 sec. } 20, \text { T. } 5 \text { N., R. } 31 \\
\text { E.; outcrop in knob south of } \\
\text { U.S. Highway } 14 \text {. }\end{array}$ & $1,280-1,340$ & 60 & $\begin{array}{l}\text { Glazed, green, sticky angular } \\
\text { to rounded, sharp edges. }\end{array}$ & 1.5 & 5.0 \\
\hline $6 \ldots$ & Grab.... & $\begin{array}{l}\text { Mobridge member } \\
\text { (Lowermost beds). }\end{array}$ & $\begin{array}{l}\text { SWi } 1 / 4 \text { sec. } 22, T .5 \text { N., R. } 29 \mathrm{E} . ; \\
\text { road cut adjacent to U. S. High- } \\
\text { way } 14 \text {. }\end{array}$ & $1,170-1,200$ & 30 & $\begin{array}{l}\text { Glazed, dark green, very } \\
\text { sticky, sharp edges, small } \\
\text { pieces. }\end{array}$ & 0.8 & 2.0 \\
\hline
\end{tabular}

Approximate specific gravity of bloated samples

$[R=$ range, $A=$ average $]$

\begin{tabular}{|c|c|c|c|c|c|c|c|c|c|c|c|c|c|c|c|}
\hline \multirow{3}{*}{$\begin{array}{l}\text { Sample } \\
\text { No. }\end{array}$} & \multirow{3}{*}{$\begin{array}{c}\text { Lowest } \\
\text { bloating } \\
\text { Temp. } \\
{ }^{\circ} \mathrm{C} \text {. }\end{array}$} & \multicolumn{14}{|c|}{ Approximate specific gravity at indicated intervals above lowest bloating temperature, ${ }^{\circ} \mathrm{C}$. } \\
\hline & & \multicolumn{2}{|l|}{$0^{\circ}$} & \multicolumn{2}{|l|}{$20^{\circ}$} & \multicolumn{2}{|c|}{$40^{\circ}$} & \multicolumn{2}{|l|}{$60^{\circ}$} & \multicolumn{2}{|c|}{$100^{\circ}$} & \multicolumn{2}{|c|}{$140^{\circ}$} & \multicolumn{2}{|c|}{$210^{\circ}$} \\
\hline & & $\mathbf{R}$ & A & $\mathbf{R}$ & $\mathbf{A}$ & $\mathbf{R}$ & A & $\mathbf{R}$ & A & $\mathbf{R}$ & A & $\mathbf{R}$ & A & $\mathbf{R}$ & A \\
\hline-2 & $\begin{array}{l}1,110 \\
1,180 \\
1,120 \\
1,160 \\
1,280 \\
1,170 \\
.\end{array}$ & $\begin{array}{r}0.9-1.5 \\
.7-1.0 \\
.7-1.7 \\
1.1-1.7 \\
1.1-1.7 \\
.9-1.4\end{array}$ & $\begin{array}{l}1.2 \\
.8 \\
1.3 \\
1.3 \\
1.3 \\
1.1\end{array}$ & $\begin{array}{r}0.7-1.5 \\
.7-1.2 \\
.7-1.7 \\
.7-1.7 \\
.7-1.2 \\
.9-1.3\end{array}$ & $\begin{array}{l}1.1 \\
.9 \\
1.2 \\
1.1 \\
1.0 \\
1.1\end{array}$ & $\begin{array}{l}0.7-1.2 \\
.6-1.1 \\
.7-1.3 \\
.9-1.2 \\
.6-1.0 \\
(1)\end{array}$ & $\begin{array}{r}1.0 \\
.9 \\
.9 \\
1.0 \\
.8 \\
-. .\end{array}$ & $\begin{array}{l}0.7-1.1 \\
.6-1.2 \\
.6-.8 \\
.6-1.0 \\
.6-.9 \\
\text { (1) }\end{array}$ & $\begin{array}{l}0.9 \\
.9 \\
.7 \\
.8 \\
.8\end{array}$ & $\begin{array}{l}0.5-1.2 \\
.7-.9 \\
.5-.8 \\
.5-.8 \\
(2) \\
(1)\end{array}$ & $\begin{array}{r}0.8 \\
.8 \\
.7 \\
.6 \\
--. \\
-.-\end{array}$ & $\begin{array}{l}0.5-0.7 \\
(1) \\
.5-.8 \\
(1) \\
(2) \\
(1)\end{array}$ & \begin{tabular}{r}
0.6 \\
\hdashline .7 \\
\hdashline- \\
-0
\end{tabular} & $\begin{array}{l}0.4-0.6 \\
(1) \\
(1) \\
(1) \\
(2) \\
(1)\end{array}$ & $\begin{array}{r}0.5 \\
\\
\end{array}$ \\
\hline
\end{tabular}

1 A bove bloating range of sample.

2 A bove $1,340^{\circ} \mathrm{C}$. 
NATURAI GAS

Artesian wells drilled in and adjacent to Pierre before 1889 had produced flows of natural gas in conjunction with water. In 1894 the city of Pierre purchased a privately owned gas well in Pierre and sold the gas for domestic use (Gries, 1940). Since 1894, at least 8 gas wells have been drilled in Pierre; some have produced as much as 85,000 cubic feet per day. The history of natural gas development at Pierre was summarized by Gries (1940, Appendix B). Production of gas by the municipalities of Pierre and Fort Pierre has now been discontinued, although some gas still is being obtained from a well drilled on the Capitol grounds by the State of South Dakota in 1943 and 1944.

Most of the gas wells have been drilled to the Dakota sandstone and underlying sandstones of Early Cretaceous age. The principal gases produced are methane 39.1 percent, ethane 7.2 percent, nitrogen 46 percent, and oxygen 7.7 percent (Pierre city engineer, written communication).

\section{MANGANESE}

The Pierre area lies at the northwestern edge of a region in which the shale and bentonite facies of the DeGrey member contains from 1 to 8 percent manganese-bearing concretions (Pesonen, Tullis, and Zinner, 1949, p. 46-71). The concretions contain from 4 to 25 percent manganese, and, in addition, the enclosing shale contains 0.04 to 3.3 percent nonconcretionary manganese. The manganese-bearing concretions in the DeGrey member are most numerous in the southeastern part of the Canning quadrangle, although they are sparsely distributed throughout the outcrop area of the member in the rest of the Pierre area.

\section{WATER}

The largest body of surface water in the area is the Missouri River. The city of Pierre draws its water supply from beds of sand and gravel that underlie the flood plain of this river, and water sufficient for domestic use can be obtained from the alluvium that underlies the valley floors of the Bad River and Medicine Creek even when there is no apparent surface discharge.

Wells put down in the more extensive outwash terrace deposits in the area generally find water in the sand and gravel just above the underlying shale. Wells in ground and end moraines locally tap beds of sand and gravel that yield potable water, and in some places the water occurs just above the underlying shale. The location of such beds can best be determined by drilling. Shallow wells in the Pierre shale generally yield little or no water.
At a number of localities in the area, artesian wells have been drilled to obtain water for livestock. These wells tap water-bearing horizons that range in altitude from about 350 feet above sea level to about 100 feet below sea level. The water apparently is obtained from the Dakota sandstone and underlying Lower Cretaceous sandstones. Information regarding artesian-water supplies for the area southwest of the Missouri River has been summarized by Rothrock and Robinson (1936, p. 66-67, 92) ; for the area northeast of the Missouri River, Searight and Meleen (1940) have summarized the available data.

Springs supply limited sources of water in some parts of the area. Springs are found most commonly above the contact between permeable glacial drift and the underlying relatively impermeable Pierre shale. Springs and seeps have been observed at several localities along the sides of the Missouri River trench and in the valley of Medicine Creek. In sec. 10, T. $110 \mathrm{~N}$., R. $78 \mathrm{~W}$, at the mouth of Mush Creek, there are large areas of swampy ground just downslope from the contact between outwash sand and gravel and the Pierre shale. Although no springs were observed at this locality when it was mapped in August 1949, residents of the area reported springs that flow during seasons of highest rainfall. The location of a prehistoric fortified Indian village on the terrace suggests that these springs have been known and used by man for a long time.

The largest concentration of springs in the area is in The Drips, a valley tributary to Medicine Creek. In the lowermost half mile of The Drips at least 11 separate springs issue from bedding surfaces and joints in shale and above the contact between glacial drift and shale. This part of The Drips contains a heavy growth of vegetation ranging from moss to sizable trees, whereas only the hardier forms of plant life such as sagebrush and grasses are present in Elm Draw and other small valleys in the area.

The discharge from a large spring in a small valley one-fourth mile west of Canning maintains the level of Lake Chesley. The water flows from glacial drift.

Six or more springs issue from the north wall of Peoria Bottom above the contact of the shale and glacial drift. One spring, in the SW1/4NE1/4 sec. 28 , T. 112 N., R. $80 \mathrm{~W}$., was discharging between 12 and 15 gallons of water per minute on September 2, 1950.

\section{SOME ENGINEERING-GEOLOGY PROBLEMS}

Prior to the start of the recent construction program in connection with Oahe Dam, engineering problems related to the geology of the Pierre area were neither abundant nor economically very serious. The area is 
not heavily populated, it is not industrialized, and there are no heavily traveled transportation routes. In the city of Pierre, construction is mainly limited to residental buildir $\mathrm{g}$.

Perhaps the most serious problem in terms of property loss and damage at Pierre and Fort Pierre is related to the periodic flooding of both communities by high water on the Missouri River. Neither community has taken effective measures to prevent these losses, although the ultimate completion of Oahe Dam will prevent serious floods caused by the Missouri River at Pierre and Fort Pierre in the future.

One problem raised during the construction of the Oahe Dam was the recognition, prevention, and stabilization of new or dormant landslides in the Pierre shale. A second, allied engineering problem related to geology is concerned with highway construction and maintenance.

RELATION OF SOME ROAD FAILURES TO GEOLOGY

Several road failures on U. S. Highway 14 in the Pierre and Oahe quadrangles were examined briefly in the summer of 1952 by the author accompanied by D. W. Hammerquist of the State Highway Commission. Each of the failures involved the bituminous mat, base course, and subbase, and occurred at places where the highway is located in a cut in Pierre shale. Most of the failures consisted of swells or sags of a few inches to as much as a foot over a distance of 10 to 100 feet along the axis of the highway. At each place where a failure was studied, a fault was found in the shale in the adjacent backslope. One such locality occurs in the NW1/4 sec. 21, T. 5 N., R. 30 E., where the highway is located in the lower part of the Virgin Creek member. Movement along a normal fault with at least 30 feet vertical displacement has brought beds of apparently different physical properties into contact. The eastern limit of the road failure is coincident with the fault trace that crosses the road obliquely; the western side of the failure coincides with a dipping bedding contact between bentonitic claystone above, and shale below. The beds east of the fault surface (footwall) dip $9^{\circ} \mathrm{E}$.; those west of the fault dip $12^{\circ} \mathrm{E}$.

Another road failure on U. S. Highway 14, in the SE1/4 sec. 14, T. 5 N., R. 30 E., occurs at a fault contact of the Verendrye member and the Virgin Creek member. On the west side of the fault (footwall; Virgin Creek member) the road surface is slightly higher than on the east side (hanging wall; Verendrye member).

A third locality examined is in the $\mathrm{SW} 1 / 4$ sec. $22, \mathrm{~T}$. 5 N., R. 29 E., where movement along a normal fault has brought the uppermost beds of the Virgin Creek member into contact with the basal beds of the Mo- bridge member. The Virgin Creek member occurs in a triangular area in the road cut, bordered on two sides by the Mobridge member from which it is separated on the east by a fault contact and on the west by a dipping bedding contact. The road failure occurs within the outcrop area of the Virgin Creek member, and consists of a swale in the road surface about 100 feet long.

There are many road failures like those described, in which there is a relation between faults or bedding contacts and the failures, along U. S. Highway 14 west of the Missouri River. Other failures occur where exposures are not now adequate to demonstrate this relationship. During highway construction a careful inspection of backslopes for abrupt lateral or vertical lithologic changes at faults and bedding contacts might give warning that special preventive measures against road failure should be undertaken before the subbase is prepared in this section.

Most of the failures described probably are related to the accumulation of excessive amounts of moisture in the materials underlying the highway; the materials thereby become plastic and cause failure of the road surface under traffic. Faults and bedding surfaces form zones of permeability in the otherwise impermeable Pierre shale; where bedding surfaces dip toward the road grade moisture can accumulate.

In the spring of 1954, drains to intercept moisture were placed along shoulders of the highway to prevent further accumulation of excessive amounts of moisture in the subgrade materials at most of the points of highway failure.

At two places in recent years, ponding of natural runoff behind highway fills has caused road failure. One occurred in June 1950 on U. S. Highway 14 about 1 mile northeast of Pierre. The outlet of a depression of about 1 acre, lying north of the highway, had been artificially closed before a period of heavy rainfall so that the water would accumulate to form a stock pond. Water soaked into the highway fill, which consists of sand, gravel, and Pierre shale with the base predominantly of reworked shale. A large mass of watersoaked material forming the south base of the fill flowed laterally southward, and by removal of support, caused the upper part of the fill and the edge of the highway to subside. When the failure was noted, the pond was drained. The remedy was to replace the portion of the fill that had subsided and to decrease the slope of the south side of the fill by adding a large mass of weathered Pierre shale.

Another failure of a road fill, on a graveled road in the SE $1 / 4$ sec. 16, T. 4 N., R. 30 E., was caused by a blocked culvert which formed a pond upstream from the fill. At this place, saturation of the Pierre shale 
slope on which the fill was built caused earth flowage and slumping in the shale which carried part of the fill downslope. The immediate remedy was to replace the slumped part of the fill with a mixture of Pierre shale and gravel without attempting to restore drainage through the fill. Further movement occurred shortly thereafter, and the ultimate remedy is not known.

These examples illustrate the need for good drainage at the base of fills, especially fills constructed of Pierre shale. Where possible it is advisable to supplement culverts with a blanket of material of high permeability at the base of fills that might, in some way, cause water to accumulate behind them. Above this permeable blanket, less permeable material is suitable.

\section{LANDSLIDES}

Landslides in the Pierre area are here subdivided, according to the type of movement involved, into slumps and flows. In slumps, movement occurs as finite shear along one or more slip surfaces; in flows, movement resembles that of a viscous liquid and slip surfaces within the material probably are nonexistent. A third subdivision complex includes slope failures that are combinations of slumping and flowage.

\section{SLUMPS}

A slump is defined as downslope movement, or rotation with little downward sliding, of a mass consisting of one or a few units. Occurrence of slumps generally is limited to Pierre shale, although slumping of shale locally has resulted in downslope movement of overlying glacial drift. Slumps in shale typically involve rotational movement, in which the uppermost part of the slump block (head) moves downward, and the lowermost part (toe) moves upward and outward. The surface along which this movement occurs generally is spoon shaped. If movement is extensive, subsidiary cracks commonly develop in the slump block, breaking it into two or more units.

A slump caused by a removal of support at the toe of a slope, is illustrated in figure 30. Many such slumps

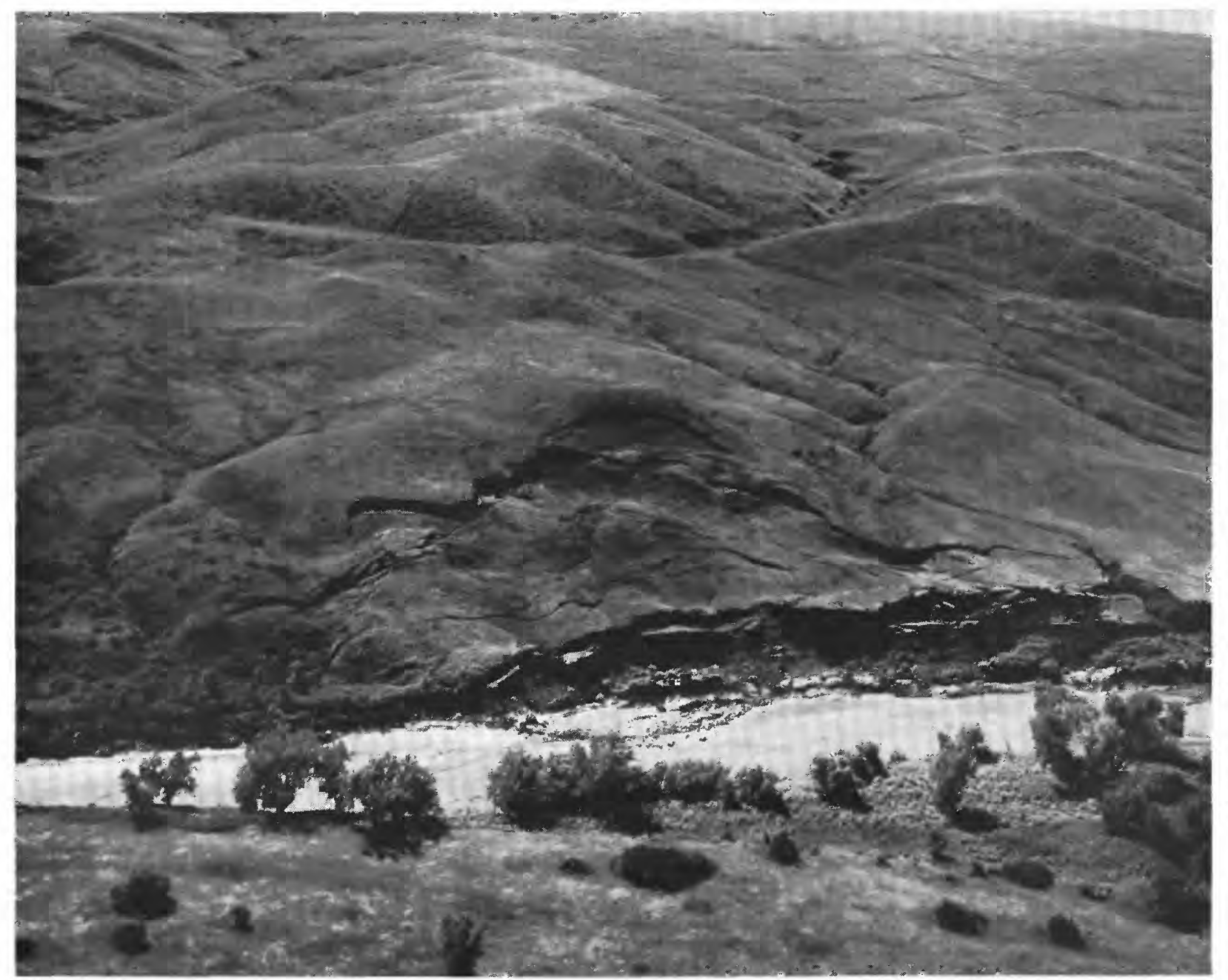

Figure 30--Aerial view of slump in the DeGrey member of the Pierre shale adjacent to the Bad River in the southeastern part of the Oahe quadrangle. 


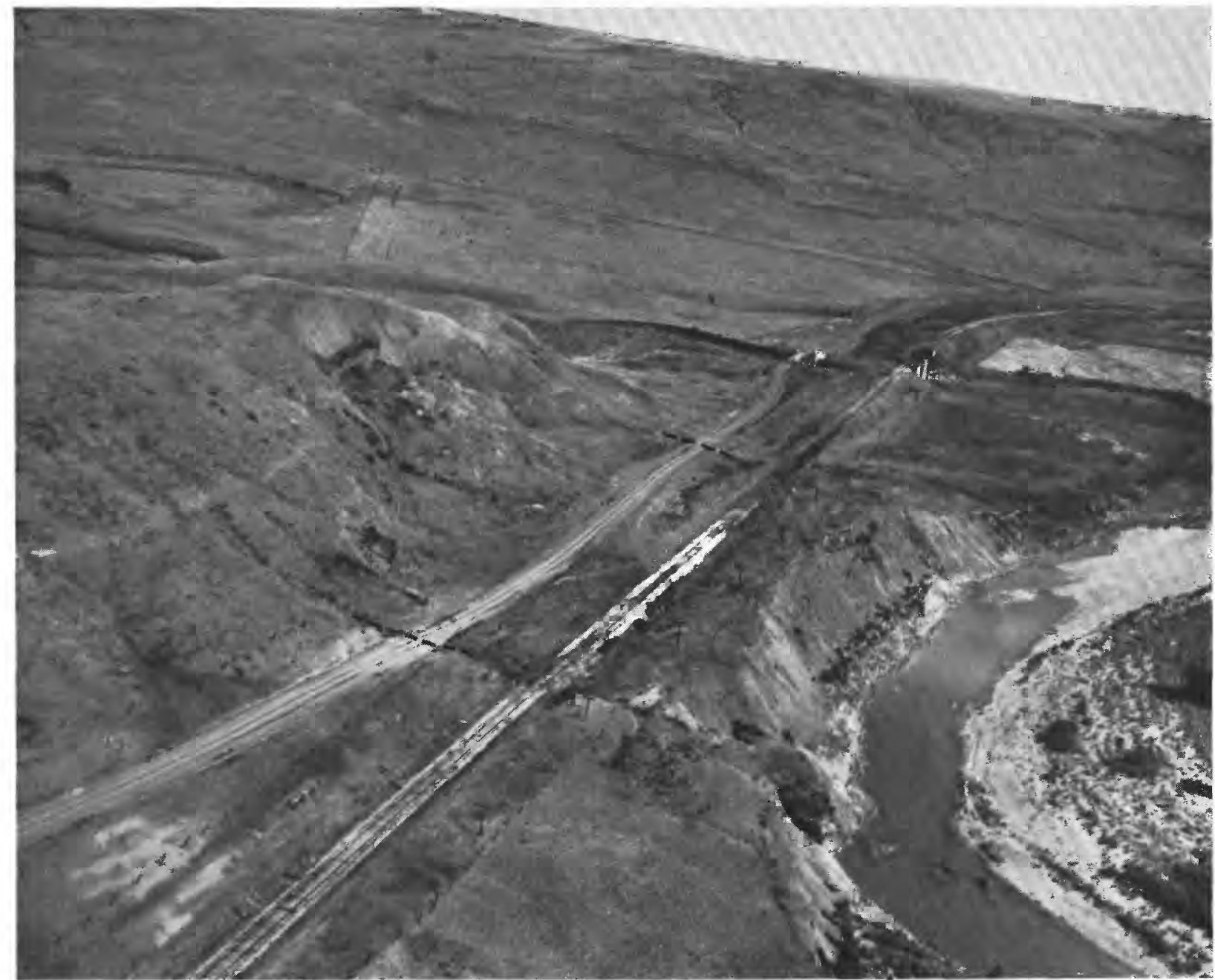

Frgure 31.-Aerial view of slump in the DeGrey and Verendrye members in SE $1 / 4$ SW $1 / 4$ sec. 32 , T. 3 N., R. $29 \mathrm{E}$. in the south-central part of the Oahe quadrangle. Intermittent movement of the slump toward the Bad River at right causes disruption of the road, railroad, telephone line, and fences. Width of slump on the road between dashed lines is 700 feet.

occur along valley walls where lateral erosion by streams removes support from toes of slopes in Pierre shale; the slumps range in size from a few tens of feet to several hundred yards in length and width.

A slump crossed by the Chicago and North Western Railway (fig. 31) has kept active for many years by erosion by the Bad River. Periodic movement of the slump toward the Bad River results in downward and lateral displacement of the railroad track. As recently as the summer of 1952, remedial measures were being undertaken at this locality only when the railroad alinement became too greatly disturbed. Corrective measures that might be undertaken are a diversion of the Bad River into a new channel to prevent further removal of toe support and installation of surface drains to prevent the accumulation of surface runoff in depressions on the slump block.

During the construction of Oahe Dam, excavations in Pierre shale caused reactivation of several large, dormant slump blocks upstream from the west abutment area of the dam. Some of these slumps were largely removed in the normal course of excavation; one has remained intermittently active and has been intensively studied by the Corps of Engineers.

A second type of slump is characterized by movement that is predominantly lateral rather than rotational. One such slump, illustrated in figure 32, is composed of a large block of glacial drift, whose volume is from 300,000 to 400,000 cubic yards. This block seems to have moved laterally as a unit with little downward movement for, if it is assumed that the contact between till and sand and gravel originally was horizontal (fig. 33), there has been less than 25 feet vertical displacement.

When this slump was studied in 1950, it was inferred that the block of glacial drift had slid laterally on a shale surface sloping more or less uniformly south 


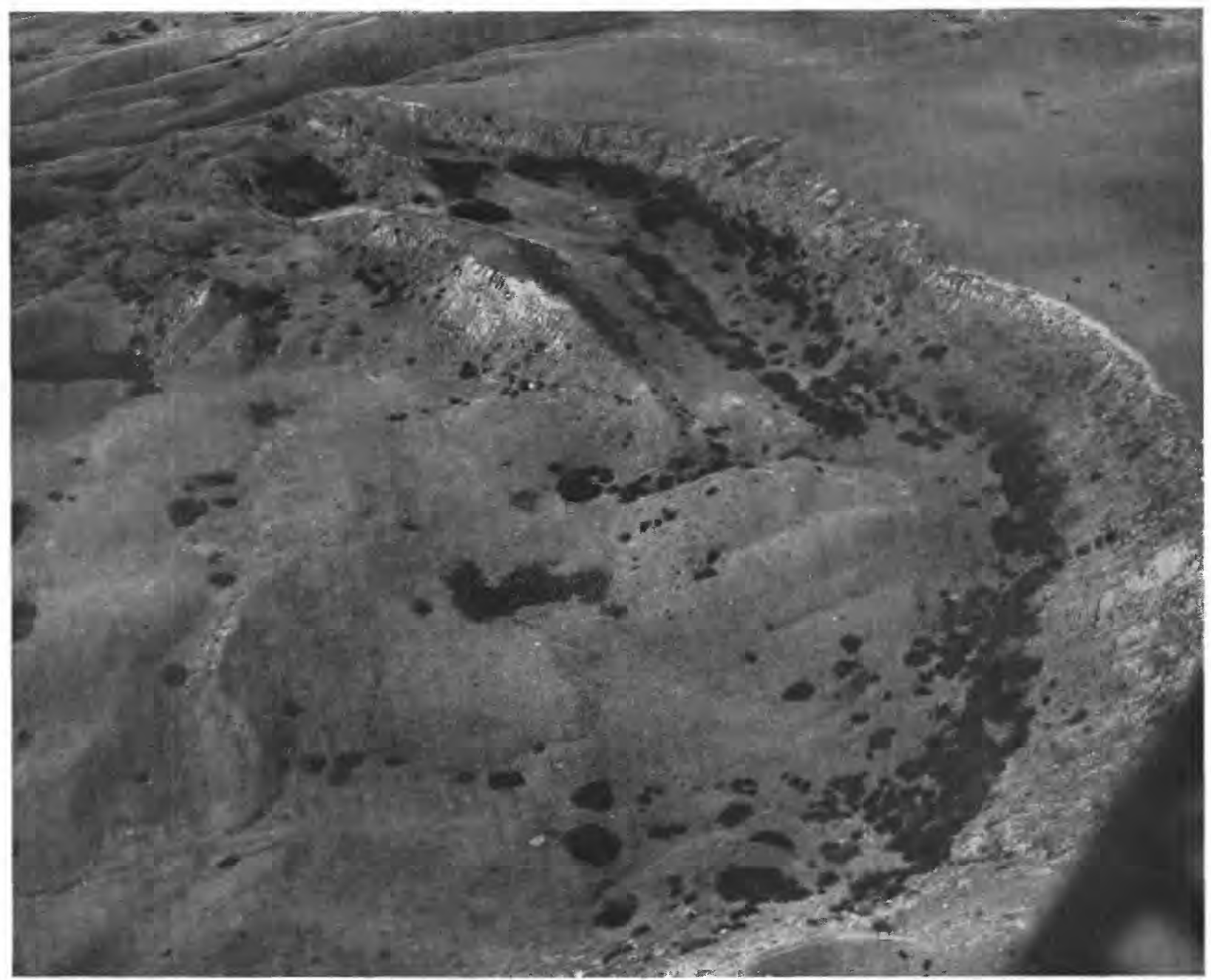

Figure 32.-Aerial view of slump characterized by lateral movement in glacial drift in NE1/4 sec. 29 , T. 112 N., R. 80 W. north of Peoria Bottom.

toward the Missouri River. ${ }^{9}$ In October, 1951, two power-auger holes were drilled in the slide area. In drill hole 2 (fig. 33), a 6-foot zone of saturated till was located at a depth of 52 feet, immediately overlying the contact of the till and shale at a depth of 56 feet (altitude 1,670 feet). As the auger brought the saturated material to the surface, the mud spread out on the ground as a fluid mass with low viscosity. In drill hole 1 , shale was found at a depth of about 90 feet (altitude about 1,650 feet). The difference in altitude of the shale surface in these two drill holes might refute the hypothesis that the shale surface slopes southward, although it is possible that the difference is a result of inaccurate logging. If the shale surface slopes northward in the slump area, it seems likely that the principal zone or surface of movement is within the glacial drift. If the shale surface slopes southward at a low angle, the main slip surface probably coincides

Crandell, D. R., 1951, Preliminary report on the geology of the Pierre quadrangle, South Dakota: U. S. Geol. Survey open-file report. at least locally with the contact of the shale and drift. The abundance of saturated material at the contact suggests that the movement has taken place along the contact.

Geologic mapping of the north wall of the Missouri River trench immediately adjacent to this slump indicates that the undisturbed contact between glacial drift and Pierre shale lies at an altitude of about 1,730 feet. It is inferred that the contact of the shale and drift is at the same altitude immediately north of the slump, and that the difference in altitude between this contact and the shale and drift contact in drill hole 1 represents the southward slope of the preglaciation valley wall in shale. The possibility that this altitude difference in the contact of the shale and drift is principally related to vertical displacement on a slump in the shale has been considered. It was noted above that the vertical displacement of the large slump block of glacial drift probably is less than 25 feet and that little or no rotation is assumed to have occurred in this block. If there 

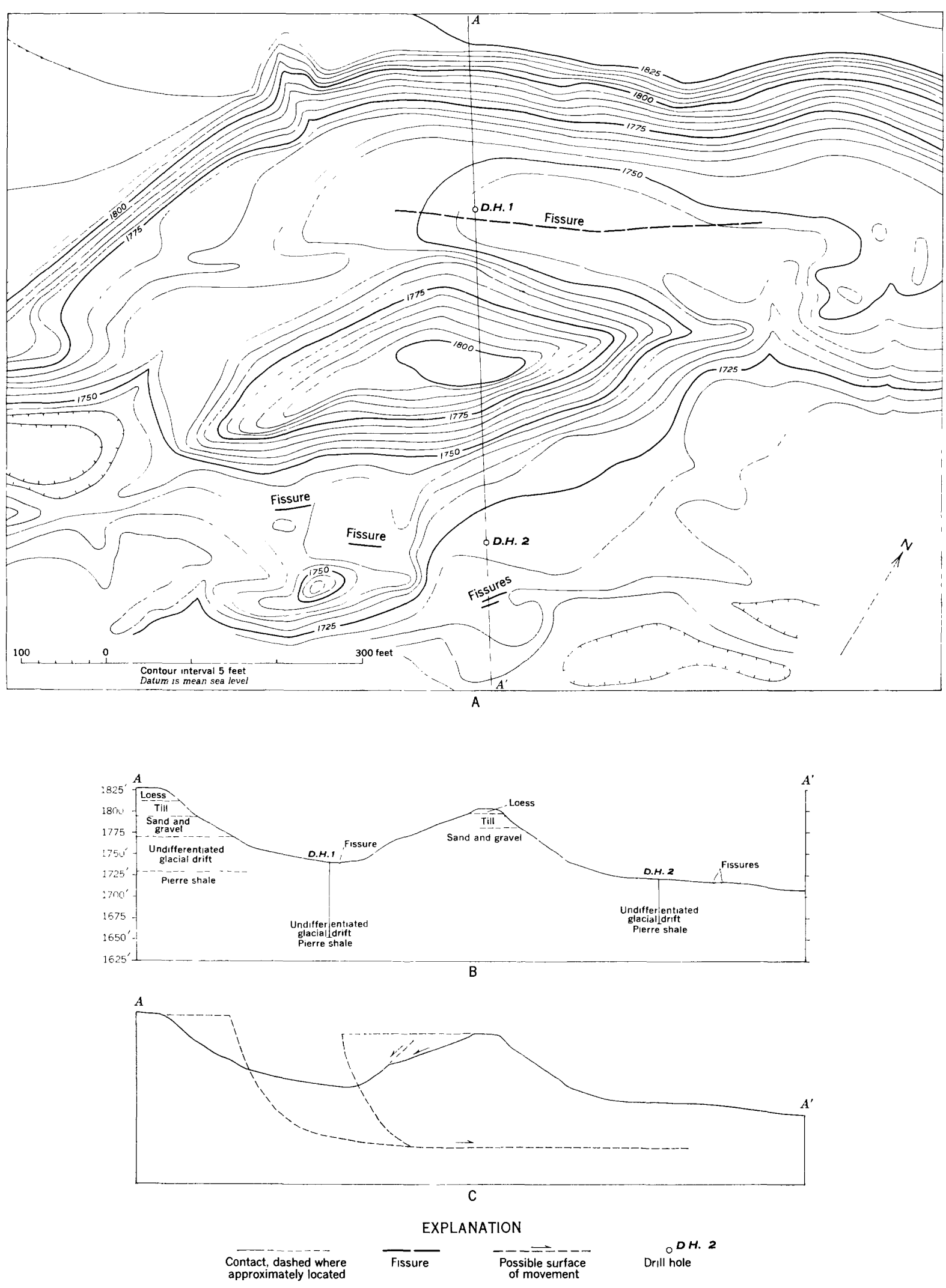

FIGUre 33.-Slump in glacial drift in the NE1/4 sec. 29, T. 112 N., R. 80 W., north of Peoria Bottom. A, Map of slump and surrounding area surveyed in August 1950. B, Profile and geologic section through the slump. C, profile and hypothetical eross section showing how slump is inferred to have developed. 
is a rotational slump in the shale, this slump is apparently unrelated to the predominantly lateral translation of the slump block of glacial drift. It seems probable, although not certain, that shale is not involved in movement in this slump area.

The author inferred (Crandell, 1952a, p. 558) that this slump has been active within the past several decades, if not within the last 10 years. A more precise date for its origin was furnished by Mrs. Evelyn P. Randolph, Superintendent of Schools of Hughes County (written communication March 4, 1953). She stated that

The slide occurred in March or April of 1922. It happened overnight-local reports at that time called it an earthquake. There must have been quite a flurry caused for the dust in the air caused the foliage of plants to be covered with dust for a great distance around. Mr. [William] Buol [Superintendent of Schools of Sully County, who lived on a nearby farm at the time of the slide] saw it the morning after it happened. He said that the outer piece seemed to drop toward the river and the other piece seemed to sink. He estimated the depth to be between flfty and one hundred feet. There was no water. He also said that he had observed the slide over the first ten years and that there was no noticeable change during that time.

From this account, and from the author's observations, it is inferred that the slide occurred primarily as a translational movement of a block of glacial drift on a slip surface or zone about 150 feet below the former ground surface. The chief cause probably was an increase in pressure of the interstitial water which decreased shearing resistance, although prior removal of toe restraint by minor slumping, flowage, and running water might well have been a contributing factor.

Cracks in the ground surface noted on figure 33 indicate that movement has been renewed at least once since the slump occurred. The largest crack ranges from 1 foot to about 5 feet deep, and is continuous throughout a distance of 450 feet. It is inferred that this fissure extends downward to the principal surface or zone of movement. There is no evidence of a new slump block now developing back of the northernmost scarp. This might be an effect of the configuration of the underlying shale surface, or might indicate that the glacial drift is in temporary equilibrium with conditions of slope and moisture supply. The saturated character of the contact of the shale and the drift implies that frictional resistance in this zone is essentially negligible. Indeed, it seems remarkable that downslope movement is not taking place. The probable reason for the apparent stability of the slump block is the presence of adequate toe restraint.

\section{FLOWs}

Flows involve the downslope movement of saturated incoherent material as a fluid mass, the viscosity of which depends largely on the proportion of liquid fraction to solid fraction. This proportion serves to distinguish earth flows (relatively little water) from mudflows (relatively much water). Given identical materials of suitable size range, a gradational series should exist between creep (relatively little water), earth flow, mudflow, and stream transport (relatively little solid). These members as well as intermediate types of movement that appear to occupy a place between some two of these members have been recognized near Pierre.

In the Pierre area, given the same degree of slope, the rate of movement of flows is directly proportional to the amount of included water; thus earth flows are characterized by slow movement, mudflows by rapid movement. Flows are common chiefly because of the highly plastic nature of the Pierre shale when weathered. If the climate were more humid, very likely flowage phenomena would be even more spectacular than they are now.

One of the largest earth flows in the area is in the SE $1 / 4$ sec. 17 , and the SW1/4 sec. 16, T. 6 N., R. 29 E. in the Oahe quadrangle. The flow is about 200 feet wide and 1,000 feet long. It originated prior to December 1938 for it can be seen on aerial photographs taken at that time. All but the uppermost 100 feet of this earth flow consists principally of Pierre shale detritus saturated with water. Downslope movement of this debris, however, causes periodic slumping of blocks of unweathered shale which move down onto the head of the earth flow, and, with continued movement, these slump blocks become part of the earth flow.

Mudflows generally are started by a sloughing off of a mantle of Pierre shale detritus on moderate to steep slopes. This process is particularly common on outcrops of the Verendrye member. The weathered surface of that member is cracked and underlain by as much as 2 feet of granular material; a viscous mass is formed that can flow downslope when a large amount of water is added to this porous material. The resulting deposit usually forms an addition to an alluvial fan at the mouth of a gully or at the toe of a slope.

A still more fluid member of the gradational series occurs during and immediately following sudden heavy rains. Gully walls collapse into the stream, which quickly becomes loaded to capacity with shale detritus. It is inferred that during some of these periods of heavy runoff, mudflows alternate with stream transport in a single gully in accordance with temporary shifts in quantity of load supplied relative to discharge. 


\section{COMBINATIONS OF FLOWS AND SLUMPS}

Combinations of flowage and slumping probably are the most common type of mass wasting in the area. As suggested above, earth flows locally cause slumps to develop owing to a removal of toe support, and some slumps have earth flows at their toes. Examples of earth flows at the toes of slumps were especially numerous in gullies along the north valley wall of the $\mathrm{Bad}$ River in secs. 33 and 34, T. 4 N., R. 29 E. in June 1952.

Broad areas of valley wall along the Missouri River have swell-and-swale topography similar to that end of moraine. By far the greater part of the hummocky areas is underlain by Pierre shale, although along the northeast valley wall there is also some till. These areas were interpreted by the author (Crandell, 1952a, p. 560) as "debris-slide deposits," chiefly because of their topography. It now seems more likely, however, that the areas are the result of slumping and earth flowage in shale which has involved some downslope movement of the overlying drift. The most extensive areas of this complex type of mass wasting are along the east wall of the Missouri River trench north of Snake Butte and along the trench wall north of Peoria Bottom.

\section{FACTORS AFFECTING MASS WASTING}

Mass wasting is caused by one or more changes that affect slope stability. Some of these changes are an increased load, a decrease in strength of soil or bedrock, and a less favorable stress distribution. A change in stress distribution might result from natural or artificial excavation at the toe of a slope, from steepening a slope, or from a change in pressure of interstitial water. An increased load might result from the addition of a large amount of water or from loading the head of a potentially unstable slope with a large volume of earth. A decrease in strength of soil or bedrock normally accompanies mechanical and chemical weathering.

Many slumps are started or reactuated during or shortly after a rainfall. The movement can be attributed chiefly to an increase in pressure of interstitial water which decreases the shearing resistance of the material. The added water also increases the weight of a unit mass and thereby might decrease its equilibrium. Under certain conditions and in some materials the added moisture might also act as a lubricant, although Terzaghi $(1950$, p. 88,89$)$ noted that sufficient water to provide lubrication almost always is present near the surface and additional water does not necessarily provide better lubrication.

The effect of added water on slope stability is strikingly illustrated by the events of the winter of 1951-52, and the following spring. Fewer than 10 large new landslides were observed in the Pierre area during the period 1948-51; in the spring of 1952 , however, many new slumps and flows occurred in the area and some old slumps were reactuated. An explanation of this lies in a combination of several factors, each of which caused more moisure than usual to soak into the ground. During the winter the ground was frozen a foot or less in depth as compared with several feet during a normal winter. The ground therefore thawed out readily and permitted much infiltration from melting snow and spring rains. Spring came with more snow than usual on the ground because there had been only minor thaws during the winter and because precipitation had been above normal. During the months of December to March, inclusive, 7.6 inches of precipitation fell in the Pierre area, an amount three times greater than the 57-year average for these months, and more than $21 / 2$ times greater than the average for the same months for the period 1948-51. It seems reasonable to predict that when these unusual conditions of climate recur in the future, similar accelerations of mass wasting in the area can be expected.

\section{LITERATURE CITED}

Baker, C. L., 1947, Deep borings of western South Dakota : South Dakota Geol. Survey Rept. Inv. 57, 112 p.

-1948, The Pennington-Haakon county central boundary area with general discussion of its surroundings: South Dakota Geol. Survey Rept. Inv. 64, 28 p.

Bolin, E. J., 1951, Areal geology of the Okobojo quadrangle: South Dakota Geol. Survey.

Calvert, W. R., Beekley, A. L., Barnett, v. H., and Pishel, M. A., 1914, Geology of the Standing Rock and Cheyenne River Indian reservations, North and South Dakota: U. S. Geol. Survey Bull. 575.

Coffey, G. N'., 1909, Clay dunes: Jour. Geology, v. 17, p. 754-755. Condra, G. E., 1908, Geology and water resources of a portion of the Missouri River valley in northeastern Nebraska: U. S. Geol. Survey Water-Supply Paper 215.

Crandell, D. R., 1950, Revision of Pierre shale of central South Dakota : Am. Assoc. Petroleum Geologists Bull., v. 34, no. 12, p. 2337-2346.

Crandell, D. R., 1952a, Landslides and rapid-flowage phenomena near Pierre S. Dak. : Econ. Geology, v. 47, no. 5, p. 548-568.

-1952b, Origin of Crow Creek member of Pierre shale in central South Dakota: Am. Assoc. Petroleum Geologists Bull., v. 36, no. 9, p. 1754-1765.

1953, Pleistocene geology of part of central South Dakota : Geol. Soc. America Bull., v. 64, no. 5, p. 581-598.

1954a, Geology of the Pierre quadrangle, South Dakota: U. S. Geol. Survey Geol. Quad. Map GQ 32.

1954b, Geology of the Canning quadrangle, South Dakota : U. S. Geol. Survey Geol. Quad. Map GQ-39.

1955, Geology of the Oahe quadrangle, South Dakota: U. S. Geol. Survey Geol. Quad. Map GQ-53.

Curtiss, R. E., 1951, Areal geology of the DeGrey quadrangle: S. Dak. Geol. Survey.

Darton, N. H., 1905, Preliminary report on the geology and underground water resources of the central Great Plains: U. S. Geol. Survey Prof. Paper 32. 
Darton, N. H., 1951, Geologic map of South Dakota : U. S. Geol. Survey. Dunbar, C. O., 1949, Historical geology : John Wiley and Sons, Inc., N. Y., $567 \mathrm{p}$.

Elias, M. K., 1931, The geology of Wallace County, Kans.: Kansas Geol. Survey Bull. 18, p. 43-131.

Flint, R. F., 1947, Glacial geology and the Pleistocene epoch: John Wiley and Sons, N. Y., 589 p.

Flint, R. F., 1949a, Leaching of carbonates in glacial drift and loess as a basis for age correlation: Jour. Geology, v. 57, p. 297-303.

1949b, Pleistocene drainage diversions in South Dakota : Geog. Annaler, Band 31, p. 56-74.

1955, Pleistocene geology of eastern South Dakota : U. S. Geol. Survey Prof. Paper 262.

Gries, J. P., 1939, A structural survey of part of the upper Missouri valley in South Dakota: South Dakota Geol. Survey Rept. Inv. 31, 44 p.

1940, A structural survey of northeastern Stanley County, S. Dak.: South Dakota Geol. Survey Rept. Inv. 34, 52 p. 1942, Economic possibilities of the Pierre shale: South Dakota Geol. Survey Rept. Inv. 43, 79 p.

—_ 1953, South Dakota steps up exploration: Oil and Gas Jour., v. 52, no. 11, p. 114-120.

1954, Cretaceous rocks of Williston Basin: Am. Assoc. Petroleum Geologists Bull., v. 38, p. 443-453.

Gries, J. P., and Rothrock, E. P., 1941, Manganese deposits of the lower Missouri valley in South Dakota: South Dakota Geol. Survey Rept. Inv. 38, $96 \mathrm{p}$.

Grim, R. E., 1942, Modern concepts of clay minerals: Jour. Geology, v. 50, p. 225-275.

Hall, James, and Meek, F. B., 1856, Description of new species of fossils from the Cretaceous formations of Nebraska, . . . : Am. Acad. Arts Sci., Mem. v. 5, p. 379-411.

Hayden, F. V., 1863, On the geology and natural history of the upper Missouri : Am. Philos. Soc. Trans., v. 12, new ser., p. 1-218.

1869, Geological report of the exploration of the Yellowstone and Missouri Rivers under the direction of W. F. Raynolds 1859-60, Govt. Printing Office, $174 \mathrm{p}$.

Hewett, D. F., 1917, The origin of bentonite and the geologic range of related materials in Big Horn Basin, Wyo. (abstract): Washington Acad. Sci. Jour. 7, p. 196-198.

Howard, A. D., 1946, Caliche in glacal chronology (abstract) : Geol. Soc. America Bull., v. 57, p. 1204.

Huffman, G. G., and Price, W. A., 1949, Clay dune formation near Corpus Christi, Tex.: Jour. Sedimentary Petrology, v. 19, no. 3, p. 118-127.

Johnston, John, and Williamson, E. D., 1916, The role of inorganic agencies in the deposition of calcium carbonate: Jour. Geology, v. 24, p. 729-750.

Leverett, Frank, 1932, Quaternary geology of Minnesota and parts of adjacent States: U. S. Geol. Survey Prof. Paper 161.

Meek, F. B., and Hayden, F. V., 1861, Descriptions of new lower Silurian, (Primordial), Jurassic, Cretaceous, and Tertiary fossils, collected in Nebraska territory, ***; with some remarks on the rocks from which they were obtained: Acad. Nat. Sci. Philadelphia Proc., p. 415-447 [1862].

Meleen, E. E., 1949, A preliminary report on the Thomas Riggs village site: Am. Antiquity, v. 14, no. 4, pt. 1, p. 310-321.

Morgan, R. E., and Petsch, B. C., 1945, A geological survey in Dewey and Corson Counties, S. Dak.: South Dakota Geol. Survey Rept. Inv. 49, 53 p.
Moxon, A. L., Olson, O. E., and Searight, W. V., 1939, Selenium in rocks, soils, and plants: South Dakota Agriculture Expt. Sta. Tech. Bull. 2, $94 \mathrm{p}$.

Moxon, A. L., Olson, O. E. Searight, W. V., and Sandals, K. M., 1938, The stratigraphic distribution of selenium in the Cretaceous formations of South Dakota and the selenium content of some associated vegetation: Am. Jour. Botany, v. 25 , no. 10 , p. 794-809.

Pesonen, P. E., Tullis, E. L., and Zinner, Paul, 1949, Missouri valley manganese deposits, South Dakota: U. S. Bur. Mines Rept. Inv. 4375, 90 p., and Rept. Inv. 4428, 63 p.

Petsch, B. C., 1946, Geology of the Missouri valley in South Dakota : South Dakota Geol. Survey Rept. Inv. 53, 78 p.

-1952, Areal geology of the Standing Butte quadrangle: South Dakota Geol. Survey.

Petsch, B. C., and Bolin, E. J., 1950, Areal geology of the Fort Bennett quadrangle: South Dakota Geol. Survey.

Petsch, B. C., and Curtiss, R. E., 1950, Areal geology of the Fort George Butte quadrangle: South Dakota Geol. Survey.

Reeside, J. B., Jr., 1944, Maps showing thickness and general character of the Cretaceous deposits in the western interior of the United States: U. S. Geol. Survey Oil and Gas Inv. Prelim. Map 10.

Rothrock, E. P., 1943, Missouri valley manganese deposits between Lower Brule and DeGrey: South Dakota Geol. Survey Rept. Inv. 46, 66 p.

- 1944, Sand and gravel deposits in the Missouri valley between Little Bend and White River: South Dakota Geol. Survey Rept. Inv. 47, 118 p.

- 1946, Logs of some deep wells in western South Dakota : South Dakota Geol. Survey Rept. Inv. 4, 108 p.

1947, Geology of the Missouri valley and vicinity near Mobridge, S. Dak. : South Dakota Geol. Survey Rept. Inv. $58,28 \mathrm{p}$.

Rothrock, E. P., and Robinson, T. R., Jr., 1936, Artesian conditions in west central South Dakota: South Dakota Geol. Survey Rept. Inv. 26, $93 \mathrm{p}$.

Rubey, W. W., 1929, Origin of the siliceous Mowry shale of the Black Hills region: U. S. Geol. Survey Prof. Paper 154-D, p. 153-170.

-1930, Lithologic studies of fine-grained upper Cretaceous sedimentary rocks of the Black Hills region: U. S. Geol. Survey Prof. Paper 165-A, p. 1-54.

Ruhe, R. V., 1950, Graphic analysis of drift topographies: Am. Jour. Sci., v. 248 , no. 6, p. $435-443$.

Russell, W. L., 1925, The possibilities of oil in western Ziebach County: South Dakota Geol. and Nat. History Survey, Circ. 20, 25 p.

1926a, The possibilities of oil in western Corson County : South Dakota Geol. and Nat. History Survey, Circ. 27, 18 p.

Russell, W. L., 1926b, Structures in western Haakon and eastern Pennington Counties: South Dakota Geol. and Nat. History Survey, Circ. $28,24 \mathrm{p}$.

1929, Drainage alignment in the western Great Plains : Jour. Geology, v. 37, p. 249-255.

- 1930, The possibilities of oil and gas in western Potter County : South Dakota Geol. and Nat. History Survey Rept. Inv. 7, $14 \mathrm{p}$.

Searight, W. V., 1937, Lithologic stratigraphy of the Pierre formation in the Missouri valley in South Dakota: South Dakota Geol. Survey Rept. Inv. 27, 63 p.

-1938, The microfauna of the Sully member of the Pierre: Iowa Acad. Sci. Proc., v. 45, p. 135-137. 
Searight, W. V., and Meleen, E. E., 1940, Rural water supplies in Hughes County, S. Dak.: Special Ext. Circ. No. 47, Ext. Service, South Dakota State College.

Stephenson, L. W., and Reeside, J. B., Jr., 1938, Comparison of upper Cretaceous deposits of Gulf region and western interior region: Am. Assoc. Petroleum Geologists Bull., v. 22, p. 1629-1638.

Terzaghi, Karl, 1950, Mechanism of landslides, in Application of geology to engineering practice: Geol. Soc. America, Berkey volume, $327 \mathrm{p}$.

Todd, J. E., 1894, A preliminary report on the geology of South Dakota: South Dakota Geol. Survey Bull. 1, $172 \mathrm{p}$. 1896, The moraines of the Missouri Coteau and their attendant deposits : U. S. Geol. Survey Bull. 144, 71 p.

1902, Hydrographic history of South Dakota : Geol. Soc. America Bull., v. 13, p. 27-40.

1908, Preliminary report on the geology of the northwest-central portion of South Dakota: South Dakota Geol. Survey Bull. 4, p. 13-76.

1914, The Pleistocene history of the Missouri River: Science, new ser., v. 39 , p. 263-274.
1923, Is the channel of the Missouri River through North Dakota of Tertiary origin?: Geol. Soc. America Bull., v. 34 , p. $469-494$.

Ward, Freeman, 1925, Structures in northern Haakon County : South Dakota Geol. and Nat. History Survey, Circ. 22, 15 p.

Warren, O. R., 1952, Probable Illinoian age of part of the Missouri River: Geol. Soc. America Bull., v. 63, p. 1143-1156.

Wentworth, C. K., 1922, A scale of grade and class terms for clastic sediments: Jour. Geology, v. 30, p. 377-392.

Wilmarth, M. G., 1938, Lexicon of geologic names: U. S. Geol. Survey Bull. 896.

Wilson, R. A., and Ward, Freeman, 1923, The possibilities of oil in northern Ziebach County: South Dakota Geol. and Nat. History Survey, Circ. 13, 11 p.

Winchester, D. E., Hares, C. J., Lloyd, E. R., and Parks, E. M., 1916, The lignite field of northwestern South Dakota: U. S'. Geol. Survey Bull. 627.

Wing, M. E., 1938, A structural survey of the Pierre gas field, South Dakota: South Dakota Geol. Survey Rept. Inv. 29, $20 \mathrm{p}$.

Wing, M. E., and Gries, J. P., 1941, Stratigraphy and structure of the Chamberlain section of the Missouri River valley: South Dakota Geol. Survey Rept. Inv. 39, 68 p. 



\section{INDEX}

Abstract

Acknowledgment

Agency shale.

See also DeGrey member of Pierre shale.

Aggregate for concrete.

Alluvial deposits, of Recent age. of the Bad River.

Ammonites

Arikara, Lake.

Artesian wells

Ash Creek

Baculites

Bad River, course of

geomorphic history of

location of ancestral course

Bad River trench, alluvial deposits in description

Belemnites

Body Ranch hill.......... 5,50

Brokenneck Creek

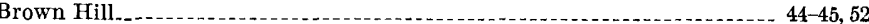

Buried soil profiles...................

C

Cary substage, geomorphic development Cary substage, glacial deposits ...... 35-37

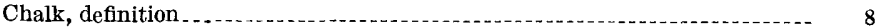

Chantier Creek

Chesley, Lake

Cheyenne River............ 50-51,52,65

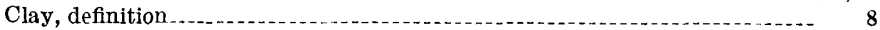

Claystone, definition... 8

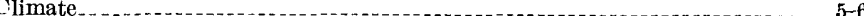

Concretions, iron manganese carbonate .......................... 12, 15, 70 limestone............. 14, 10

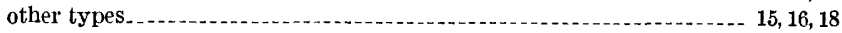

Coteau du Missouri.

Cretaceous rocks

Crow Creek member of Pierre shale, fossils _ _. 12

origin ................... 11-

name assignment

Culture-...................

Deflation basins

$5,47-50$

Deformation, cause of

DeGrey member of Pierre shale, concretions in

definition.

description

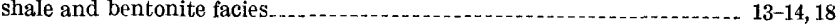

thickness.................- 14

DeHart Draw _..._.

Divide areas, established by Illinoian time..... 50-52

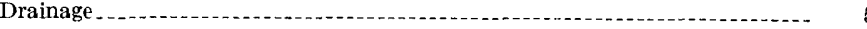

Drainage pattern, deflation basin hypothesis of origin ... eolian hypothesis of origin . . .

longitudinal dune hypothesis of origin $\ldots \ldots \ldots$

time of origin

trend............ 45-46

Drips, The

Dry Run, tributary to Missouri River

Dry Run valley, outwash deposits in ................... 28-29, 33

Dune sand. . .
E Page

Earlier studies of the area.....

Economic geology Butte member of Pierre shale, description

Engineering-geology problems . -

Eolian hypothesis of origin of drainage pattern......... 46-49

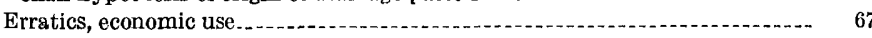
modes of deposition

time of deposition

Fan deposits........

Farm Island .................... 5, 43, 67

Faults, description relation to drainage pattern relation to road failures.

Fieldwork

Fill material

Flint, R. F., quoted.

Floods.................... 71

Flows _............... 76-77

Folds

Foraminifera

Fort George Buttes_.............. 50

Fort Pierre .

Fossils, ammonites...

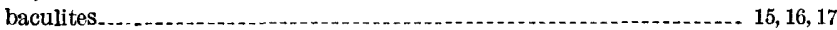

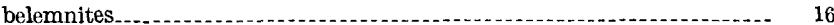

bison skull................ 37

fish-scale-bearing beds .

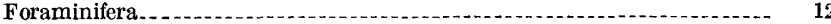

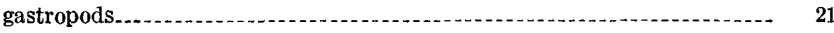

in deposits of Pleistocene age $\ldots \ldots \ldots$

in Fox Hills sandstone. . .

in loess deposits $\ldots$

in the Pierre shale.......... $8-9,10,11,12,14,15,16,17$

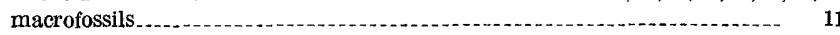

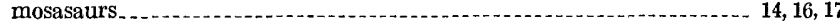

pelecypods $\ldots$. . . . . . . . . . .

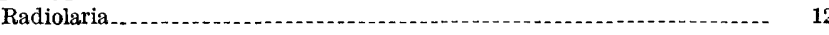

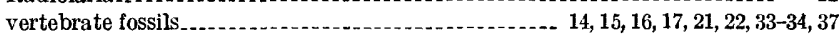

Fox Hills sandstone. . . . . . . .

Gastropods, fossil $\mathrm{G}$

Geography_.........

Geologic history

Geomorphic history

Giddings Flat_......... 5, 30, 53

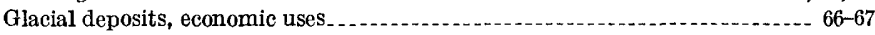
of Cary substage, westernmost extent of Iowan substage, southernmost extent of ........... 29-32

of Tazewell substage, southernmost extent of ......................... 35

Gravel deposits, economic use

Gregory member of Pierre shale, description

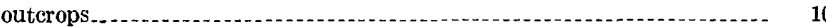

source of name

Gries, J. P., quoted.

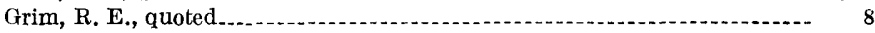

Hard rock.

H

Hayden, F. V., quoted.

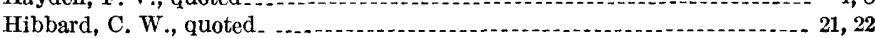

Hilgers Gulch., quoted.

Illinoian age, nonglacial deposits of
Illinoian stage, geomorphic development 
Introduction

lowan substage, geomorphic development.

proglacial oucwash deposits.

stratified drift

till of

Iowan-Tazewell interval, geomorphic development

Joints

$$
\mathrm{J}
$$

\section{K}

Kansan time, geomorphic development

\section{I.}

La Framboise Island

Landslides.

Jeonard, A. B., fossils identified by

quoted.

Limestone pebbles, percent of, in Cary till

Literature cited.

Location of the Pierre area.

Loess, buried soil profiles in. conditions favoring deposition. depth of leaching.

fauna in

rate of accumulation

terminology of.

thickness.

Loess deposition

\section{M}

Manganese.

M

Mankato substage, deposits of

Marl, definition.

Mass wasting, factors affecting

Medicine Butte

Medicine Creek

- 5, 54,55

Medicine Knoll

Missouri River, drainage pattern. ................ 52

Missouri River flood plain _..._..................... 57, 66

Missouri River trench, development of . $\ldots \ldots \ldots \ldots$ origin of

stratified drift in

Mobridge member of Pierre shale, description . . fossils.

outcrops...

selenium in.

thickness.

Montana group.

Mosasaur bones.

14,16,17

Moxon, A. L., Olson, O. E., and Searight, W. V., quoted

$32-33,36$
$-\quad 16$

\section{$\mathrm{N}$}

Natural gas

Natural resources......... $66-70$

Nonglacial deposits, of Illinoian age

of pre-Kansan age.

of Yarmouth age

0

Oacoma zone

See also DeGrey member of Pierre shale.

Oahe Dam

Okobojo Creek.

P

Paleozoic rocks

$\mathbf{P}$

Peoria Bottom, fan deposits in outwash deposit in

Pierre, city.

Pierre Municipal Airport, stratigraphic section for till deposit

Pierre shale, bloating characteristics of

Crow Creek member.-

DeGrey member

economic uses.

Elk Butte member
1-4

\section{5}

29

7

Pierre shale,-Continued

environment of deposition

fossils in

Gregory member........ 10

lithologic character

Mobridge member

Sharon Springs member.

source of name........ 8

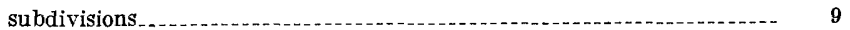

summary of changes in nomenclature

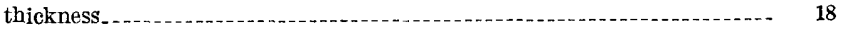

Verendrye member.

Virgin Creek member $\ldots \ldots \ldots \ldots$ 15-16

Pierre hills region.............. 5

Pleistocene deposits. . . . . .

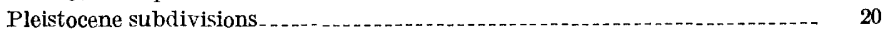

Precambrian rocks

Pre-Kansan age, nonglacial deposits of

Pre-Wisconsin glacial deposits, lack of .

Proglacial outwash deposits, of Iowan substage

Purpose of the study

$\mathrm{R}$

Radiolarja_......... 12

Randolph, Mrs. Evelyn P., quoted......................................... 76

Recent age, deposits of

Ree Hills.

Relief - .

Road failures, relation of to geology

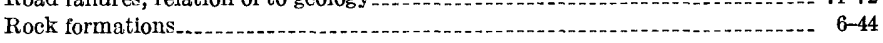

Russell, W. L., quoted........ 46, 58

\section{$\mathrm{S}$}

Sand deposits

Sangamon age, absence of deposits of

Sangamon stage, geomorphic development

Schultz, C. B., quoted .

Scope of the study $\ldots . . . . . .2$

Searight, W. V., quoted

with Moxon, A. L., and Olson, O. E., quoted... 16

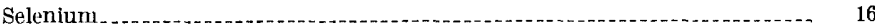

Shale, definition

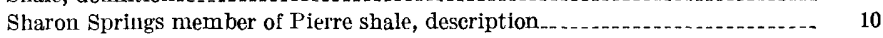

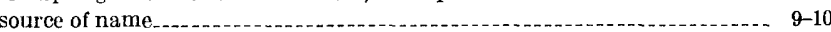

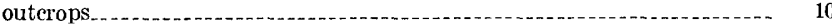

thickness.

Siumps

Soil

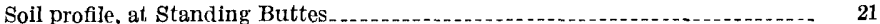

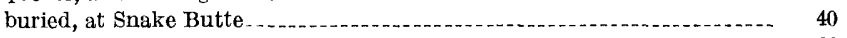

buried, in loess . . .

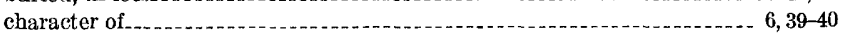

of Stroup deposit.............. 22

Soil test data

South Dakota Highway Commission, Soils Laboratory, data on soil tests

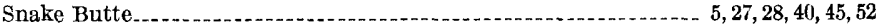

Spring Creek

Spring Creek valley, outwash deposits in 33

Spring deposits......................... 42-43

Springs...................................... 70

Standing Buttes, Pleistocene deposits on

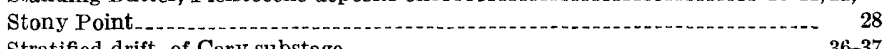

Stratified drift, of Cary substage

of Iowan substage . .

of Mankato substage... 38

of Tazewell substage

See also Stratigraphic sections.

Stratigraphic sections $\ldots . . . \ldots \ldots \ldots \ldots \ldots \ldots, 28,40-42$

Stratigra phy, subsurface correlation chart summary of changes in nomenclature . .

Stroup deposit, description. ....... 22-23

fossils in

rock types at, proportions of

soil profile of

Structure, cause of deformation.

faults._._.

folds

investigations of . . . joints 
Sully Buttes

Page

44,50

$\mathrm{T}$

Tazewell-Cary interval, geomorphic derelopment Tazewell substage, deposits of . . . (1)

Terrace allu vium

Tertiary age, absence of deposits of

Till, of Cary substage

of Iowan substage. .............. 27-28

of Tazewell substage

Todd, J. E., quoted. .

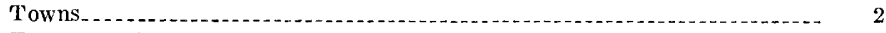

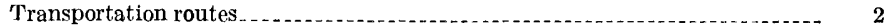

Travertine deposits......... $42-43$

\section{U}

U. S. Bureau of Mines, test data by

\section{$\mathrm{V}$}

Vegetation, principal types toxic.

Verendrye member of Pierre shale, concretions description

description
Vertebrate fossils.
(1)

6

16
Virgin Creek member of Pierre shale, bentonite beds

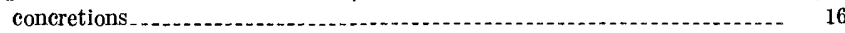

description. . .

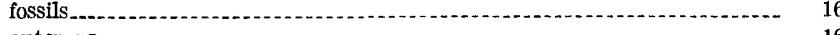

outcrops.

W

Ward, Freeman, quoted............ $58-59$

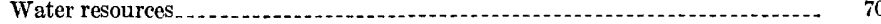

Whiskey Gulch, outwash deposit near...... 33

White River, ancestral geomorphic history of

Will, George M, quoted.... 42

Willow Creek

Willow Creek Butte, alluvial deposits on ...................... 20, 21-23, 44, 50 location......... 5

Willow Creek valley, proglacial outwash deposits in.................. 28-29

Wind action. See Eolian hypothesis of origin of drainage pattern.

Wisconsin age, deposits of .

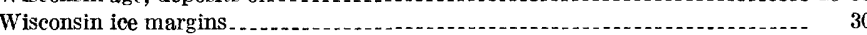

Wisconsin stage, geomorphic development___ 54-58

Wisconsin stage, till of

Wood Island...................... 43

Yarmouth age, nonglacial deposits of $\mathbf{Y}$

Yarmouth stage, geomorphic development 